UNIVERSIDADE DE SÃO PAULO

FACULDADE DE FILOSOFIA, LETRAS E CIÊNCIAS HUMANAS DEPARTAMENTO DE LETRAS MODERNAS

PROGRAMA DE PÓS-GRADUAÇÃO EM LÍNGUA, LITERATURA E CULTURA ITALIANAS

ROBERTA REGINA CRISTIANE BELLETTI

\title{
A poesia de Giacomo Leopardi e suas traduções brasileiras: temas e problemas
}

São Paulo 
UNIVERSIDADE DE SÃO PAULO

FACULDADE DE FILOSOFIA, LETRAS E CIÊNCIAS HUMANAS DEPARTAMENTO DE LETRAS MODERNAS

PROGRAMA DE PÓS-GRADUAÇÃO EM LÍNGUA, LITERATURA E CULTURA ITALIANAS

\section{A poesia de Giacomo Leopardi e suas traduções brasileiras: temas e problemas}

Roberta Regina Cristiane Belletti

Dissertação apresentada ao Programa de PósGraduação em Língua, Literatura e Cultura Italianas do Departamento de Letras Modernas da Faculdade de Filosofia Letras e Ciências Humanas da Universidade de São Paulo, para a obtenção do título de Mestre em Letras.

Orientadora: Prof. ${ }^{\text {a }}$ Dr. ${ }^{\text {a }}$ Lucia Wataghin

São Paulo 


\section{FOLHA DE APROVAÇÃO}

Roberta Regina Cristiane Belletti

A poesia de Giacomo Leopardi e suas traduções brasileiras: temas e problemas

Aprovada em:

Banca Examinadora

Dissertação apresentada ao Programa de PósGraduação em Língua, Literatura e Cultura Italianas do Departamento de Letras Modernas da Faculdade de Filosofia Letras e Ciências Humanas da Universidade de São Paulo, para a obtenção do título de Mestre em Letras.

Prof. Dr.

Instituição:

Assinatura:

Prof. Dr.

Instituição:

Assinatura:

Prof. Dr.

Instituição:

Assinatura: 
A minha querida mãe, Clarinda;

A meu caro pai, André;

A meus estimados irmãos, Paula e Bruno.

Minha família - meu porto seguro! 


\section{AGRADECIMENTOS}

* À Prof. ${ }^{a}$ Dr. ${ }^{a}$ Lucia Wataghin, pela orientação e por acreditar no meu potencial;

* À Prof. ${ }^{a}$ Dr. ${ }^{a}$ Norma S. Goldstein e ao Prof. Dr. Pedro G. Ghirardi, pelas preciosas e pertinentes sugestões dadas durante o Exame de Qualificação;

* À Prof. a Maria Rafaella Pedretti, do Ensino Fundamental "Don Alberto Carozza" (Salsomaggiore - Itália), por ter me apresentado com tanta paixão o poeta Giacomo Leopardi, de modo a marcar o caminhar de meus estudos.

* A minha família, por incentivar e apoiar meu trabalho, aconselhando-me e transmitindome calmaria em todos os momentos;

A meus amigos, pelas risadas e parcerias nos momentos mais importantes;

Ao CNPq, pelo valioso apoio na minha pesquisa, por meio da concessão de bolsa de estudos. 
“Em meio à escuridão da noite, há sempre estrelas para quem tem olhos para olhar o céu. Em meio a um campo devastado, haverá sempre uma flor para quem sabe olhar"

Hugo Baggio 


\section{RESUMO}

A presente pesquisa tem como finalidade apresentar uma leitura da obra poética de Giacomo Leopardi, com um olhar atinente à estilística. A fim de abrir horizontes, no sentido de novas pesquisas e perspectivas da poética leopardiana, escolheu-se fazer um cotejo entre poemas selecionados e as suas traduções em língua portuguesa do Brasil, paralelamente, de modo que a análise estilística, feita em etapas, contribua para mostrar o sentido presente no texto poético, sentido esse que pode estar alterado na versão traduzida. Quatro foram os poemas escolhidos: $I l$ passero solitario, L'infinito, Canto notturno di un pastore errante dell'Asia e La ginestra, o il fiore del deserto, representando um conceito que circula há tempo, mas que se acredita manter a sua importância, referente às fases do pessimismo leopardiano: individual, histórico, cósmico e heroico.

Palavras-chave: Giacomo Leopardi; estilística; tradução; literatura italiana; pessimismo leopardiano 


\begin{abstract}
The present study is to present a reading of the poetry of Giacomo Leopardi, with a look regards on the stylistic. In order to open horizons to new research and perspectives of Leopardi's poetry we chose to make a comparison between the selected poems and their translations into Portuguese of Brazil, in parallel, so that the stylistic analysis, done in stages contributes to show the sense in this poetic text, meaning that it can be altered in the translation. Four poems were chosen: Il passero solitario, L'infinito, Canto notturno di un pastore errante dell'Asia e La ginestra, o il fiore del deserto, representing a concept that circulate for some time, but believed to remain important, on stages of Leopardi's pessimism: individual, historical, cosmic and heroic.
\end{abstract}

Keywords: Giacomo Leopardi, stylistics, translation, Italian literature; Leopardis pessimism 


\section{LISTA DE OBRAS PICTÓRICAS}

Quadro 1

IL PASSERO SOLITARIO N ${ }^{\circ} 2$ - Antonio Bertè $\quad$ p.54

Quadro 2

L'INFINITO - Antonio Bertè

p.73

Quadro 3

CANTO NOTTURNO DI UN PASTORE ERRANTE DELL'ASIA - Antonio Bertè

p. 88

Quadro 4

LA GINESTRA $N^{\circ} 2$ - Antonio Bertè

p.113 


\section{SUMÁRIO}

\section{Introdução}

1.0 O lirismo leopardiano.

p. 11

p.32

1.1 Classificação dos gêneros da poesia segundo Leopardi p.32

1.2 A modernidade da poesia leopardiana $\quad p .32$

1.3 A importância do gênero lírico para Leopardi $\quad$ p.34

2.0 Considerações sobre a interpretação de um texto poético e de sua tradução $\quad$ p.41

2.1 Diálogo entre a língua e a literatura: análise interpretativa de poemas $\quad$ p.41

2.2 Dificuldade e importância da tradução poética p.45

3.0 Análise interpretativa de poemas leopardianos e de suas traduções p.54

3.1 O canto solitário de um poeta: pessimismo individual p.54

3.1.1 Il passero solitario de Leopardi no Brasil; $\quad$ p.58

3.2 Um passeio no infinito: pessimismo histórico p.73

3.2.1 L'Infinito de Leopardi no Brasil p.81

3.3 A reflexão profunda de um pastor: pessimismo cósmico p.88

3.3.1 Canto notturno di un pastore errante dell'Asia de Leopardi no Brasil $\quad$ p.92

3.4 O perfume exalado de uma flor do deserto: pessimismo heroico p.113

3.4.1 La ginestra o il fiore del deserto de Leopardi no Brasil p.116

$\begin{array}{lr}\text { Considerações finais } & \text { p.153 }\end{array}$

$\begin{array}{ll}\text { Bibliografía: } & \text { p.160 }\end{array}$

- Do autor p.160

- Sobre o autor e obra p.161

- Sobre análise-interpretativa p.164

- Sobre tradução e teoria da tradução p.167

- Dicionários e Gramáticas p.169

- Sitografia $\quad$ p.170

$\begin{array}{ll}\text { Anexos } & \text { p.171 }\end{array}$ 


\section{Introdução}

Neste trabalho, far-se-á uma análise estilística de alguns poemas de Giacomo Leopardi. Escolheu-se analisar a produção poética leopardiana por acreditar na sua força expressiva, além de se reconhecer a importância da poesia lírica, vista como gênero literário, dentro da literatura.

Ao considerar o caráter supremo da poesia dentro da literatura, compartilha-se do pensamento de Antonio Candido, para o qual a poesia:

é tomada como a forma suprema de atividade criadora da palavra, devida a intuições profundas e dando acesso a um mundo de excepcional eficácia expressiva. Por isso a atividade poética é revestida de um caráter superior dentro da literatura, e a poesia é como a pedra de toque para avaliarmos a importância e a capacidade criadora desta. Sobretudo levando em conta que a poesia foi até os tempos modernos a atividade criadora por excelência, pois todos os gêneros nobres eram cultivados em versos. Hoje, o desenvolvimento do romance e do teatro em prosa mudou este estado de coisa, mas mostra por isto mesmo como toda a literatura saiu da nebulosa criadora da poesia. (2006, p. 19)

Também Leopardi deixa claro em suas notas do Zibaldone di pensieri [2940] ${ }^{1}$ o seu apreço pela poesia, utilizada já pelos primeiros doutos:

"E infatti i primi sapienti furono i poeti, o vogliamo dire i primi sapienti si servirono della poesia, e le prime verità furono annunziate in versi ${ }^{2} . "$ (11 Luglio 1823)

$\mathrm{Na}$ análise que se seguirá neste trabalho, será observada a expressividade dos poemas, ou seja, se dará particular atenção ao modo como o sentido é produzido e afeta a percepção do leitor, por meio de recursos linguísticos. Para Guirraud (1970, p.25) gênero e estilo são inseparáveis,

\footnotetext{
${ }^{1}$ O Zibaldone di Pensieri é uma obra sob a forma de diário com mais de 4 mil páginas, em que constam apontamentos e reflexões de Leopardi escritos ao longo de sua vida (de 1817 até 1832). Os números entre colchetes representam a numeração das páginas do autógrafo leopardiano do Zibaldone, conservado na Biblioteca Nacional de Nápoles. Ao longo desta pesquisa, recorrer-se-á muitas vezes a essas anotações, pois de maneira geral, elas tratam de temas importantes presentes na poética do autor.

2 "E de fato os primeiros sábios foram os poetas, ou melhor, os primeiros sábios serviram-se da poesia, e as primeiras verdades foram anunciadas em versos" (11 de julho de 1823) - [Trad. nossa]
} 
pois para cada gênero, correspondem modos de expressão definidos, que determinam toda a composição poética.

Um dos papéis da estilística é o de interpretar as escolhas apresentadas no poema, centralizando o olhar do estudioso no texto e não mais no seu autor. Todavia, a figura do autor não permanece esquecida de tudo e o que se instaura aqui é um triângulo de interação, formado por autor - texto - leitor. O autor faz suas escolhas - tanto de palavras como de combinações no momento da criação da obra; o efeito estilístico criado no texto é percebido durante a leitura, resultando em uma determinada reação do leitor, podendo ela ser diferente de leitor para leitor, conforme seu repertório de leitura e sua formação discursiva.

Conforme Dubois explica em seu Dicionário de lingüística, "a tarefa da estilística é identificar a reação do leitor diante de um texto e encontrar a fonte de suas reações na forma do

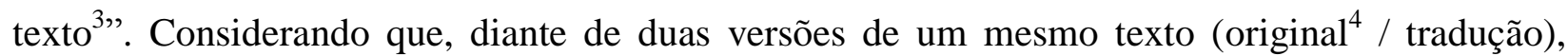
podem-se ter reações distintas, o que seguirá neste trabalho é uma análise estilística em etapas do texto poético original, paralelamente a uma análise, também estilística, do texto traduzido, em função de suas semelhanças e diferenças. Dessa forma, é possível perceber as principais diferenças de significação entre a nossa leitura do original e do texto traduzido.

Traduzir, do latim traducere, significa "transpor, trasladar de uma língua para outra", mas considerar a tradução como um simples ato de substituição de um signo para outro parece ser uma definição muito tecnicista. Utilizar um método definido que se possa aplicar objetivamente, com validade geral, em qualquer tipo de texto, parece não ser o melhor caminho para a tradução.

Tratando-se de um estudo literário, mais especificamente de poemas, a dificuldade da tradução é ainda maior, pois não basta o tradutor ter o conhecimento da língua de partida, acredita-se aqui que seja necessário também ser dotado de uma sensibilidade poética, saber

\footnotetext{
${ }^{3}$ DUBOIS et alii, 2001, p. 239

${ }^{4}$ Para Arrojo, (Oficina de tradução, 1992, p.79), “o 'original' se refere ao texto a partir do qual se 'origina' a tradução". Todavia, Arrojo alerta o leitor também à critica existente contra tal termo por partir do pressuposto que a tradução de um texto jamais será perfeita, sendo uma cópia inferior à matriz original. Para evitar tal preconceito, Arrojo sugere o termo: texto de partida. Ao longo da dissertação referir-se-á ao texto que origina a tradução como original, sem pressupostos de inferioridade do texto traduzido.

${ }^{5}$ Dicionário Aurélio Eletrônico - Século XXI - Versão 3.0 - Novembro de 1999.
} 
recriar a expressividade do poema de forma deliberada, bem como possuir uma habilidade para poetar, semelhante à do poeta produtor do texto de partida. Sendo assim, prefere-se não definir a tradução como uma mera transferência de palavras de uma língua a outra, mas como afirma Arrojo (1992, p.80) “traduzir, mais do que transferir é transformar”.

Para isso, o tradutor deve aprender a "ler" o poema. Saber "ler" um poema implica, em primeiro lugar, aceitar que todos os elementos que o constituem, mesmo se aparentemente desprovidos de significado, contribuem à interpretação. Daí a importância de se cotejar estilisticamente o poema e sua tradução.

Do ponto de vista estilístico, as escolhas sonoras dos poemas são extremamente importantes para atrair a atenção do leitor. Conforme afirma Matoso Câmara (1956, p.65) “a insistência do som o torna, por sua vez, o centro emotivo da composição e prepara a ambientação emotiva do leitor ou do ouvinte".

Dessa forma, demonstrar a importância do signo em um poema, a sua expressividade e sonoridade como elementos contribuintes para a formação de sentido, será o destaque dessa pesquisa.

Por meio desta pesquisa, apresentar-se-á o estudo de um importante representante da literatura italiana: Giacomo Leopardi, portanto, seguirá aqui uma breve apresentação do autor em questão, evidenciando três aspectos fundamentais de sua biografia: o ano de seu nascimento e o relacionamento com seus pais e com a sociedade.

Nascido em 1798 na cidade chamada Recanati, então pertencente ao Estado Pontifício das Marcas, Giacomo Leopardi cresce no seio de uma família aristocrática, filho do conde Monaldo Leopardi e da marquesa Adelaide Antici. O ano de seu nascimento foi considerado importante para a história dessa cidadezinha, digno de ser anotado nos Anais Recanatenses, pois, foi em 1798 que os costumes nobres e dignos de se andar com espadas e vestir-se de preto decaem dos hábitos aristocráticos. É o mundo se transformando e a modernidade que começa a dar sinal, mas 
o conde Monaldo, apreciador dos costumes aristocráticos, procura manter sua postura, vestindose de preto com sua espada ao lado, demonstrando assim sua dignidade patrícia.

Desse modo de se comportar, percebe-se quão reacionário é seu pai, uma pessoa que olha em direção ao passado, ao ponto de fundar em seu palácio uma Academia Poética, com a finalidade de restabelecer a Academia dos Desiguais, existente no século XV em Recanati. É então que começa a recolher exemplares de livros, comprados a baixo custo, e monta uma vasta biblioteca, onde mais tarde Giacomo dedicar-se-á a anos de estudos.

Após um grande período de gastos excessivos, o patrimônio da família Leopardi se dissipa. Com uma dívida muito alta a pagar, o conde Monaldo é interditado legalmente e quem assume as rédeas dos negócios familiares é a marquesa Adelaide Antici.

Adelaide Antici, como sua própria filha a descreve em uma carta "è una persona ultrarigorista, un vero eccesso di perfezione cristiana, la quale non potete immaginare quanta severità metta in tutti i dettagli della vita domestica. Veramente ottima donna e esemplarissima, si è fatta delle regole di austerità assolutamente impraticabili, e si è imposti dei doveri verso i figli che non riescono loro punto comodi ${ }^{6}$."

Sua mãe fora figura muito importante para Giacomo Leopardi, visto que representava o "vero" (real), sem ilusões. O modo como a marquesa se comportava e como via o mundo influencia, em parte, a gênese do pensamento leopardiano, mostrando-lhe como os efeitos da religião prejudicam a imaginação. Em uma passagem do Zibaldone, [353-355], Leopardi afirma:

Io ho conosciuto intimamente una madre di famiglia che non era punto superstiziosa, ma saldissima ed esattissima nella credenza cristiane, e negli esercizi della religione. Questa non solamente non compiangeva quei genitori che perdevano i loro figli bambini, ma gl'invidiava intimamente e sinceramente, perchè questi eran volati al paradiso senza pericoli, e avean liberato i genitori dall'incomodo di mantenerli. [...] Considerava la bellezza come una vera disgrazia, e vedendo i suoi figli brutti o deformi,

\footnotetext{
${ }^{6}$ Carta de Paolina a Giacomo Leopardi, 26 maio 1830.

(http://www.archive.org/stream/leopardi00robegoog/leopardi00robegoog_djvu.txt) - acesso: 30/11/2009 às 15h.

"É uma pessoa ultrarrigorista, um verdadeiro excesso de perfeição cristã, a qual vocês não podem imaginar quanta severidade coloca em todos os detalhes da vida doméstica. Realmente ótima mulher e exemplaríssima, criou regras de austeridade absolutamente impraticáveis, e impôs-se alguns deveres em relação aos filhos que para eles não são nem um pouco cômodos.” [Trad. nossa]
} 
ne ringraziava Dio, non per eroismo, ma di tutta voglia. Non procurava in nessun modo di aiutarli a nascondere i loro difetti, anzi pretendeva che in vista di essi, rinunziassero intieramente alla vita nella loro prima gioventù: se resistevano, se cercavano il contrario, se vi riuscivano in qualche minima parte, n'era indispettita, scemava quanto poteva colle parole e coll'opinion sua i loro successi [...] cercava studiosamente l'occasione di rinfacciar loro, e far loro ben conoscere i loro difetti, e le conseguenze che ne dovevano aspettare, e persuaderli della loro inevitabile miseria, con una veracità spietata e feroce ${ }^{7}$. (25 novembre 1820)

Para Leopardi a religião cristã considera mal tudo aquilo que em sua opinão é natural, e que por sinal é bem, como por exemplo, a beleza, a juventude, a riqueza, entre outros, pois essas condições apresentam um risco para a alma, predispondo-a ao pecado ${ }^{8}$.

Esta era a figura materna vista por Leopardi e, como já afirmado, o motivo desse sentimento sem piedade e de agressividade da mãe, deve-se para o autor à religião e assim diz no Zibaldone [355]: “Questa donna aveva sortito dalla natura un carattere sensibilissimo, ed era stata così ridotta dalla sola religione. Ora questo che altro è se non barbarie ?"’(25 novembre 1820)

Em relação ao ambiente onde morava, Recanti, Leopardi sentia-se cada vez mais prisioneiro, por se tratar de uma cidade longe do centro, sendo, portanto, difícil a chegada das grandes novidades da época.

Em uma carta ao seu amigo Pietro Giordani, um famoso literato classicista da época, datada 30 de abril de 1817, Leopardi lamenta-se do ambiente onde vive e de seus conterrâneos:

È un bel dire: Plutarco, l'Alfieri amavano Cheronea ed Asti. Le amavano e non vi stavano. A questo modo amerò ancor io la mia patria quando ne sarò lontano; ora dico

\footnotetext{
7 “Eu conheci intimamente uma mãe de família que não era por nada supersticiosa, mas solidíssima e diligentíssima nas crenças cristãs e nos exercícios da religião. Essa não somente não se compadecia daqueles pais que perdiam seus filhos crianças, mas os invejava íntima e sinceramente, porque esses tinham voado ao paraíso sem perigos e tinham liberado seus pais do incômodo de mantê-los. [...] Considerava a beleza como uma verdadeira desgraça e vendo seus filhos feios e deformes, agradecia a Deus por isso, não por heroísmo, mas de todo coração. Não tentava de nenhum modo ajudá-los a esconder seus defeitos, pelo contrário pretendia que os vendo, renunciassem por completo à vida na sua primeira juventude: se eles resistissem, se tentassem o contrário, se conseguissem em qualquer mínima parte, aborrecia-se, rebaixava o quanto podia com as palavras e com a sua opinião seus sucessos [...] procurava estudiosamente a ocasião para jogar em suas caras, e fazê-los conhecer bem seus próprios defeitos, e as consequências que deveriam ter, e persuadi-los de sua inevitável miséria com uma veracidade impiedosa e feroz." [Trad. nossa]

${ }^{8}$ Zib. [2456]: 4 junho 1822.

9 "Esta mulher tinha herdado da natureza um caráter sensibilíssimo, e foi assim reduzida unicamente pela religião. Agora isso o que mais é se não barbárie?” (25 de novembro de 1820) - [Trad. nossa]
} 
di odiarla perchè vi son dentro, chè finalmente questa povera città non è rea d'altro che di non avermi fatto un bene al mondo, dalla mia famiglia in fuori. [...] Che la Marca e 'l mezzogiorno dello Stato Romano sia come la Romagna e '1 settentrione d'Italia? Costì il nome di letteratura si sente spessissimo: costì giornali accademie conversazioni librai in grandissimo numero. [...]Qui, amabilissimo Signore mio, tutto è morte, tutto è insensataggine e stupidità. Si meravigliano i forestieri di questo silenzio, di questo sonno universale. Letteratura è vocabolo inudito. I nomi del Parini dell'Alfieri del Monti, e del Tasso, e dell'Ariosto e di tutti gli altri han bisogno di commento ${ }^{10}$.

Em um ambiente como esse, Leopardi sente-se sufocado; sua única diversão é o estudo, diversão que ele mesmo diz matá-lo, pois consumia boa parte de sua saúde ao ficar horas a fio na biblioteca paterna.

Além dessa “desilusão pessoal”, aos poucos desenvolve-se também nele uma "desilusão histórica", já que para o poeta, a condição negativa do homem no presente não deriva unicamente de uma condição individual, mas também de um processo histórico. $\mathrm{O}$ afastamento do homem da condição original, oferecida pela natureza, destrói as ilusões que tornavam sua vida suportável. Sendo assim, os antigos eram capazes de grandes ilusões; já o homem moderno não, pois as perdeu. Por isso, a crítica denomina tal fase de "pessimismo ${ }^{11}$ histórico" leopardiano, pois ele afirma que a infelicidade humana é fruto de uma condição histórica.

Após alguns anos, Leopardi finalmente consegue sair de Recanati, e passa, então, a viver em diferentes cidades italianas: Roma, Milão, Bolonha, Florença, Pisa e Nápoles. Mas logo percebe quão ilusória era a sua ideia de que fora de Recanati existisse vida e felicidade; o autor logo descobre a nulidade eterna e imutável das coisas.

\footnotetext{
${ }^{10} \mathrm{http}: / /$ docenti.lett.unisi.it/frontend/?rr=BD_49_11 (30/11/2009 às 19h)

"É belo dizer: Plutarco e Alfieri amavam Cheronea e Asti. Amavam-nas, mas lá não estavam. Deste modo, também eu amarei minha cidade quando estiver distante, agora afirmo odiá-la porque estou nela, que afinal, não é culpada senão por nunca me ter feito um bem - afora minha família. [...] Que as Marcas e o sul do estado romano sejam como a Romanha e o norte da Itália? Aí, ouve-se freqüentemente o nome de literatura; aí há jornais, discussões, academias, livreiros em profusão... Aqui meu amabilíssimo senhor, tudo é morte, tudo é insensato e estúpido. Os forasteiros se espantam com este silêncio, com este sono universal. Literatura é palavra que não se escuta. Os nomes de Parini, Alfieri, Monti, de Tasso, Ariosto e de tantos outros necessitam de comentário." (LUCCHESI: 2006; pp.702-703)

${ }^{1}$ Ao longo da história literária, a crítica escolheu um termo clássico para caracterizar as fases do pensamento leopardiano: o "pessimismo", termo esse que se preferiu manter nessa pesquisa, embora alguns críticos optaram por outros termos como "dor - desilusão - infelicidade", já que o próprio Leopardi não fez uso do termo "pessimismo" em suas considerações. Nota-se na passagem do Zibaldone [4174] em que Leopardi, após afirmar que tudo é mal, tudo aquilo que existe é mal, ele especifica que esse seu sistema, por mais que urte com as ideias de seu tempo, em que tudo é bem, ele não ousaria dizer que o universo existente seja o pior dos possíveis, substituindo assim o otimismo ao pessimismo. (22 de Abril de 1826).
} 
Neste período, historicamente, a Itália estava sofrendo uma forte traição de seus ideais iluministas. Por meio da instauração opressiva da Restauração, os cidadãos veem seus ideais de progresso e de liberdade tirânica, tão defendidos no Iluminismo, frustrarem-se. Da mesma forma sente-se Leopardi ao perceber como a natureza brinca com os homens: inicialmente proporcionalhes falsas ilusões de um destino ditoso, mas quando eles descobrirem, por meio da razão, a verdadeira finalidade da natureza - a perpetuação da vida do universo - terão suas ilusões destruídas.

Leopardi sai então da esfera pessoal, dirigindo sua atenção ao absoluto, atribuindo a culpa da infelicidade do homem não mais à razão, mas à natureza que o guia a esse destino. Desenvolve-se, assim, o "pessimismo cósmico" leopardiano.

Já na sua fase final de vida, Leopardi volta sua atenção ao homem, deixando uma mensagem não mais de isolamento, mas de solidariedade humana. Nasce a sua fase "heroica", em que encoraja o homem, privado de suas ilusões, a encarar racionalmente e com dignidade o seu destino.

Em 1837, no dia 14 de junho, Giacomo Leopardi, já com um estado de saúde agravado irremediavelmente, morre, em Nápoles, na casa do amigo Ranieri. Este último o salva da vala comum, decretada pelo governo devido à epidemia de cólera que se abateu na cidade naquele período. Graças, então, à intervenção do amigo para com o pároco de São Vital, em Fuorigrotta, que o corpo de Leopardi é enterrado em uma sala subterrânea da igreja. Em 1939, os restos mortais do poeta foram transferidos para o Parque Vergiliano, em Piedigrotta - Mergellina, onde atualmente Giacomo Leopardi descansa próximo ao túmulo de outro grande poeta italiano: Virgilio.

Ao longo da história literária, a crítica dedicou boa parte de sua atenção a caracterizar o pessimismo leopardiano. Principalmente a partir da segunda metade do século XIX, muitos estudiosos discutiram longamente sobre essa questão.

O primeiro grande nome italiano a comentar a obra de Leopardi foi Francesco De Sanctis, que lhe dedicou vários estudos. Para ele, o Leopardi-filósofo apresenta um pessimismo superficial, pessimismo esse que se contradiz no Leopardi-poeta, já que seus poemas despertam 
um efeito positivo. De Sanctis defende o lado positivo da poética leopardiana em sua obra intitulada Schopenhauer e Leopardi (1857) em que diz:

Leopardi produce l'effetto contrario a quello che si propone. Non crede al progresso, e te lo fa desiderare; non crede alla libertà, e te la fa amare. Chiama illusioni l'amore, la gloria, la virtù, e te ne accende in petto un desiderio inesausto. E non puoi lasciarlo, che non ti senta migliore; [...] È scettico e ti fa credente; e mentre non crede possibile un avvenire men tristo per la patria comune, ti desta in seno un vivo amore per quella e t'infiamma a nobili fatti. Ha così basso concetto dell'umanità, e la sua anima alta, gentile e pura l'onora e la nobilita. [...] e mentre chiama larva ed errore tutta la vita, non sai come, ti senti stringere più saldamente a tutto ciò che nella vita è nobile $\mathrm{e}$ grande. $^{12}$

Em um tempo em que predomina a leitura pessimista das obras leopardianas, curiosamente, De Sanctis chega a defender um lado otimista escondido no pessimismo leopardiano. O crítico defende seu ponto de vista dizendo que:

La vita non appartiene all'intelletto, ma alla volontà; e l'uomo vive e vuol vivere, ancorché l'intelletto gli scopre la vanità della vita. Finché l'immaginazione e il sentimento sono vivi, nascono nel pensiero care illusioni che ti allettano alla vita, come nei popoli e negli uomini giovani. E anche quando le care illusioni sono dileguate al soffio malefico della scienza o del vero, la vita rimane intatta, quando ci sia la forza d'immaginare, di sentire e di amare: che é appunto il vivere. ${ }^{13}$

Conforme defende De Sanctis, por mais que o homem tenha descoberto, por meio do conhecimento, a inutilidade da vida, sua vontade de viver permanece por conta da força da imaginação, do sentimento e do amor. Por isso, para o crítico, o lirismo leopardiano - em que o

\footnotetext{
${ }^{12} \mathrm{http}: / /$ www.liberliber.it/bibliotec...penhauer_e_leopardi/html/texto.htm (acessado em 10/02/2010 às 18h30min) "Leopardi produz o efeito contrário ao que se propõe. Não acredita no progresso e te faz desejá-lo, não acredita na liberdade e te faz amá-la. Chama de ilusões o amor, a glória, a virtude e te acende no peito um desejo inesgotável. E tu não consegues deixá-lo, sem te sentir melhor; [...] é cético e te faz crente; e enquanto não acredita possível um futuro menos triste para a pátria comum, te suscita no peito um vivo amor por ela e te inflama a nobres feitos. Tem tão baixo conceito da humanidade, e a sua alma alta, gentil e pura a honra e a nobilita. [...] e enquanto chama larva e erro toda a vida tu não sabes como, se sente agarrar mais fortemente a tudo aquilo que na vida é nobre e grande." [Trad. nossa]

${ }^{13}$ DE SANCTIS; Studio su Giacomo Leopardi, Napoli: Morano, 1885, p.282.

"A vida não pertence ao intelecto, mas à vontade; e o homem vive e quer viver, mesmo se o intelecto lhe descobre a inutilidade da vida. Enquanto a imaginação e o sentimento estiverem vivos, nascem no pensamento caras ilusões que te encorajam para a vida, como nos povos e nos homens jovens. E mesmo quando as caras ilusões desvanecerem ao sopro maléfico da ciência e do real, a vida permanece intacta, enquanto existir a força de imaginar, de sentir e de amar: que é de fato o viver." [Trad. nossa]
} 
objetivo do poeta é levar alento às dores sentidas pelo homem ${ }^{14}$ - apresenta um pessimismo superficial.

Já no início do século XX, Bonaventura Zumbini fez um importantíssimo estudo sobre o pessimismo leopardiano, intitulado Studi sul Leopardi ${ }^{15}$. Com base no Zibaldone, individuou fases na desilusão leopardiana, momentos que serão considerados por muitos outros críticos, e que até o presente momento possuem um forte valor didático.

Leopardi considerou que o ano mais importante na história de sua vida foi o ano de 1819, por conta da total mutação ocorrida em sua vida. Mais precisamente, nesse período, Leopardi se viu privado do uso da visão, e consequentemente de sua maior distração: a leitura. Devido a tal infortúnio, como o próprio poeta diz em o Zibaldone: "cominciai a sentire la mia infelicità in un modo assai più tenebroso, cominciai ad abbandonar la speranza, a riflettere profondamente sopra le cose, a divenir filosofo di professione (di poeta ch'io era) a sentire l'infelicità certa del mondo [...] ${ }^{16, "}$ (144: 2 Luglio 1820). Por isso Leopardi diz ter ocorrido nele a passagem do estado antigo ao moderno, já que para ele os verdadeiros poetas eram os antigos, enquanto os modernos, não são nada além de filósofos.

Para Zumbini, não somente a enfermidade contribui para a mutação intelectual do poeta, mas também o fato de a natureza ter lhe dado uma grande faculdade intelectiva que com o tempo se converteu em uma fonte de dor. Na biblioteca paterna, Leopardi passou boa parte de seu tempo estudando e meditando sem fim, virando um prisioneiro, sequestrado do mundo, fato que lhe impedia a glória, a grandeza e a felicidade, tanto desejadas como imaginadas. O poeta teve também uma difícil relação com o pai, de cumplicidade no início, mas que logo se transformou em divergente. O pai não conseguia entender mais o filho, ambos discordavam sobre ciência, religião, política, ou seja, as ideias de um eram o oposto das do outro.

Por esses entre outros motivos, Zumbini afirma que Leopardi:

\footnotetext{
${ }^{14}$ LEOPARDI; Zibaldone - [4234] ( 15 Dicembre 1826)

15 ZUMBINI, B. Studi sul Leopardi; Firenze: Le Monnier; 1902.

16 "comecei a sentir a minha infelicidade em um modo muito mais tenebroso, comecei a abandonar a esperança, a refletir profundamente sobre as coisas, a virar filósofo de profissão (de poeta que eu era) a sentir a infelicidade certa do mundo." (2 de Julho de 1820) [Trad. nossa]
} 
incominciò, come dice egli stesso, a sentire la sua infelicità in un modo assai più tenebroso: questo significa che, come vediamo subito anche dagli effetti, incominciò a sentire nell'infelicità propria quella degli altri: significa il suo passare dal proprio individuo alla storia umana e alle leggi che la governano. ${ }^{17}(1902$, p.111)

Com tal afirmação, Zumbini individua a passagem da dor pessoal de Leopardi para uma fase do "dolore storico" (dor histórica), chamada por alguns críticos de "pessimismo histórico". Sintetizando quanto afirma o crítico, nessa nova fase, Leopardi interpreta a história fundamentando-se na inimizade existente entre a natureza e a razão, em que demonstra ser a primeira benéfica enquanto que a segunda, o seu oposto. Para o poeta a infelicidade humana iniciou com a perda da condição primitiva, tempo em que tudo parecia ser harmonioso e belo, perda que com o passar do tempo, juntamente com o progresso da razão, causou um aumento gradativo da infelicidade.

Mas essa condição histórica, entre outros motivos, não significa segundo Zumbini o ápice da dor humana. A partir das Operette morali Zumbini pormenoriza outra fase da desilusão leopardiana, chamada de "dolore universale" (dor universal), também conhecida como "pessimismo cósmico".

“L'infelicità, anche se l'uomo se la fosse poi acresciuta coll'opera propria, deriva sempre dai germi posti dalla natura stessa in tutte le cose; quindi, infelicità necessaria, eterna e universale. $^{18, "}(1902$, p.196)

Nessa fase, Leopardi modifica sua visão quanto ao afirmado anteriormente sobre a grandeza da natureza em relação à razão, e passa a ver a natureza como a grande causadora da infelicidade.

Uma vez admitidas terríveis descobertas do pensamento, o crítico pergunta-se sobre o que se resta a fazer para que a vida não seja tão infeliz. Com base nos estudos feitos das últimas obras de Leopardi, Zumbini conclui apostando na mensagem leopardiana de resignação, de paciência e

\footnotetext{
17 "começou, como ele mesmo diz, a sentir a sua infelicidade de modo muito mais tenebroso: isso significa que, como logo se vê também nos efeitos, começou a sentir na infelicidade própria aquela dos outros: significa o seu passar do próprio indivíduo à história humana e às leis que a governam.” [Trad. nossa]

18“A infelicidade, mesmo se o homem a tivesse aumentado por meio de seus próprios feitios, deriva sempre dos germes colocados pela própria natureza em todas as coisas; portanto, infelicidade necessária, eterna e universal." [Trad. nossa]
} 
de necessidade de se reduzir aos mais estreitos confins os desejos e as esperanças, vivendo dia após dia, hora após hora; aconselhando vivamente uma aliança universal contra aquela que oprime o tudo: a natureza.

Para outro grande crítico, Benedetto Croce, o pessimismo leopardiano é uma consequência de sua infelicidade. Em sua obra, Poesia e non poesia ${ }^{19}$, Croce afirma que Leopardi era um jovem que se preparava para ser um grande filólogo, estudioso das línguas e das literaturas da antiguidade clássica, que espera as joias do amor, mas que infelizmente, teve "una vita strozzata" (uma vida estrangulada) por uma força brutal:

"da quella che egli chiamò la «nemica Natura », che gli spezzò gli studi, gli proibì i palpiti del cuore, e lo rigettò su sé stesso, cioè sulla sua offesa base fisiologica, costringendolo a combattere giorno per giorno per sopportare o lenire il malessere e le sofferenze fisiche che lo tormentavano invincibili. ${ }^{20,}$ (1923, p.108)

Aos poucos, diz Croce, foi se formando no intelecto de Leopardi uma teoria filosófica sobre o mal, a dor, a inutilidade e a nulidade da existência; todos sentimentos projetados a partir de seu próprio estado de infelicidade. Daí a tendência leopardiana em acreditar que a vida fosse um mal, e que teria de ser vivida com essa amarga consciência. (1923, p.109)

Entre as obras de Leopardi, Croce reconhece o valor artístico somente nas poesias idílicas que são muito inspiradoras, brotadas da alma do poeta, o qual cria lindas imagens que tocam o coração do leitor, ${ }^{21}$ diferentemente das demais produções.

Sendo Croce uma figura renomada, muitos foram os estudos influenciados pela sua crítica. Foi somente mais adiante, por volta da segunda metade do século XX, que surgiram novos estudos sobre a obra leopardiana, direcionando a atenção sobretudo para o último

\footnotetext{
${ }^{19}$ CROCE, B. "Poesia e non poesia". Bari: Gius. Laterza \& Figli, 1923, pp.103-119

20 "por àquela que ele chamou de "inimiga Natureza", que lhe truncou os estudos, lhe proibiu as palpitações do coração, e fez com que ele se voltasse para si mesmo, ou seja, para sua ofendida base fisiológica, obrigando-o a combater dia após dia para suportar ou atenuar o mal-estar e os sofrimentos físicos que o atormentavam invencíveis." [Trad. nossa]

${ }^{21}$ A propósito dessa ideia lê-se em Croce: "Chi non porta nella memoria e nel cuore le immagini che in essa affiorano, le divine immagini, figure di fanciulle, aspetti di paesaggio, opere di umile gente? (1923:116)

"Quem não traz na memória e no coração as imagens que nela afloram, as divinas imagens, figuras de crianças, aspectos da paisagem, trabalhos de gente humilde?" [Trad. LUCCHESI, 1996, p.53]
} 
Leopardi, um poeta progressivo e não mais solitário como nos idílios. Grandes nomes como Walter Binni, Cesare Luporini, Sebastiano Timpanaro, entre outros, contribuem para identificar uma linha heroica no pensamento leopardiano.

Em 1947, Walter Binni escreve La nuova poetica leopardiana, em que apresenta estudos dos últimos cantos de Leopardi, apoiados na prosa das Operette morali e nas reflexões do Zibaldone.

Binni ressalta o porquê dos críticos considerarem "poesia” somente a produção idílica leopardiana:

Questo infatti è il punto dolente del problema leopardiano: chi giunge ai nuovi canti dopo la lettura dei grandi idilli si trova disorientato di fronte a così grande diversità e questa impressione si cambia facilmente in giudizio comparativo ed in svalutazione delle nuove poesie considerate come deviazione dal motivo trionfante della poesia idillica. E poiché non si approfondisce di solito se non episodicamente e psicologicamente la situazione del nuovo Leopardi e non la si vede in funzione di poetica, è facile assumere la posizione idillica come l'unica posizione veramente leopardiana ed ogni divergenza di tono come infiacchimento e turbamento d'ispirazione. ${ }^{22}(1947$, p.4)

Sempre segundo a visão do crítico, o poeta, em seu último período, passa a ter uma posição mais afirmativa e combativa; distingue o progresso humano como progresso de consciência da situação humana; defende a construção de uma civilização desiludida e solidária; além de fazer da razão uma arma sólida com a qual os homens podem e devem se libertar de mitos e consolações soberbas e frívolas.

No mesmo ano, Luporini, em Leopardi progressivo ${ }^{23}$, afirma que o pensamento leopardiano nasce de uma experiência trágica, experiência, assim como foi dito, de "una vita strozzata", mas por mais que tenha sido uma vida sufocada, continua sendo sempre uma vida, a qual pode ser altamente indicativa.

\footnotetext{
22 "Este de fato é o ponto fraco do problema leopardiano: quem chega aos novos cantos depois da leitura dos grandes idílios vê-se desorientado diante de tão grande diversidade e esta impressão muda facilmente em parecer comparativo e em desapreço das novas poesias consideradas como desvio do motivo triunfante da poesia idílica. E uma vez que normalmente não se aprofunda, se não episodicamente e psicologicamente a situação do novo Leopardi,ela não é vista em função de poética, é fácil assumir a posição idílica como a única posição realmente leopardiana e cada divergência de tom como enfraquecimento e turbamento da inspiração.” [Trad. nossa]

${ }^{23}$ LUPORINI, C. Leopardi progressivo; In: "Filosofi vecchi e nuovi"; Firenze: Sansoni, 1947 (Hoje em "Leopardi progressivo"; Roma: Editori Riuniti, 1980)
} 
Para Luporini, a desilusão leopardiana não nasce somente de seu íntimo dissídio, mas também de um drama histórico. A razão setecentista ao mesmo tempo em que é condenada pelo poeta também é amada, pois ela havia acendido nos homens tantas esperanças. Mas essa razão, que deveria ter destruído as barbáries, as superstições, instaurado a igualdade e a democracia, trazido ao homem o justo e são equilíbrio com a natureza, destruído pelo Cristianismo, faliu.

Ao contrário do que alguns críticos afirmam, Luporini não crê na negação do progresso da parte do poeta, já que Leopardi não via o homem e a história de forma estática. Destacando o lado progressista de Leopardi, Luporini afirma:

"Leopardi fu un pensatore progressivo: in certo modo, dentro i limiti della sua funzione moralista, di non-tecnico della filosofia né di alcuna disciplina particolare, il più progressivo che abbia avuto l'Italia nel XIX sec. ${ }^{24,}(1980$, p.10)

Para Luporini, na última fase leopardiana existe algo novo que é o desenvolvimento do valor positivo do agir humano, da energia humana, da universal solidariedade dos homens contra a hostilidade ou a indiferença da natureza. $\mathrm{O}$ homem, portanto, não deve se iludir e sim se unir com seus semelhantes numa guerra comum:

E questo, per Leopardi, sarà il vero ritorno alle origini dell'uomo, che è ormai in tutto uomo-sociale: non il ritorno alla mítica 'natura' in cui l'uomo s'immerge selvatico e solitario, ma il ritorno al senso originario della comunità umana, della 'social catena': non catena che lega e costringe, ma catena che salda chi fraternamente collabora. ${ }^{25}(1980$, p.101)

Interessante é o estudo feito por Sebastiano Timpanaro, Classicismo e illuminismo nell'Ottocento italiano (1965), que apresenta uma relação entre o pessimismo e o progressismo de Leopardi.

\footnotetext{
24 "Leopardi foi um pensador progressivo: de certo modo, dentro dos limites da sua função moralista, de não-técnico da filosofia nem de qualquer disciplina em particular, o mais progressivo que tenha existido na Itália do século XIX." [Trad. nossa]

25 "E este, para Leopardi, será o verdadeiro retorno às origens do homem, que já é por completo homem-social: não o retorno à mítica 'natureza' em que o homem se imerge selvagem e solitário, mas o retorno no sentido originário da comunidade humana, da 'social catena': corrente que não prende e constringe, mas que salda quem fraternamente colabora." [Trad. nossa]
} 
Para o estudioso, no pensamento de Leopardi as exigências progressistas nunca dominaram o pessimismo, pelo contrário, em sua última fase o progressismo e o pessimismo exaltam-se e potenciam-se reciprocamente.

Para explicar tal pensamento, Timpanaro percorre as fases do pessimismo leopardiano. Para ele no "pessimismo storico" (entre 1819 e 1822), o poeta parece se orientar em direção a uma missão de poeta civil, fase em que ainda não se tem, rigorosamente, um pessimismo. O que se tem aqui é a vivíssima intolerância da atmosfera estagnada da Itália e da Europa da Restauração, é o vaguejar uma sociedade republicana, livre de superstições mortificantes e de ascetismo, mas também de excessos de racionalismo e de refinamento, capaz de viver uma vida intensa sob o impulso de enérgicas e magnânimas ilusões ${ }^{26}$.

Já no "pessimismo cosmico", tem-se a tese da radical e incurável infelicidade do homem. Para Timpanaro, a passagem do primeiro ao segundo pessimismo não é puramente fruto de um desenvolvimento intelectual, mas também de experiências práticas de Leopardi, como o agravar de sua condição de saúde bem como de sua deformidade física.

Muitos críticos atribuem o pessimismo leopardiano somente ao seu sofrimento pessoal, mas essa ideia não é defendida por Timpanaro, o qual acredita ser tudo isso um grosseiro equívoco.

Leopardi sempre protestou vivamente contra esse acostamento entre infelicidade pessoal e pessimismo. Pode-se perceber, em uma parte da famosa carta escrita por Leopardi ao seu amigo filólogo De Sinner, datada 24 de maio de 1832, que:

l'on a voulu considérer mes opinions philosophiques comme le résultat de mês souffrances particulières, et que l'on s'obstine à attribuer à mês circonstances matérielles ce qu'on ne doit qu'à mon entendement. Avant de mourir, je vais protester contre cette invention de la faiblesse et de la vulgarité, et prier mes lecteurs de s'attacher à détruire mes observations et mes raisonnements plutôt que d'accuser mes maladies. ${ }^{27}$

\footnotetext{
${ }^{26}$ TIMPANARO, S. Classicismo e illuminismo nell'Ottocento italiano. Pisa: Nistri-Lischi, 1965, pp. 140-74. in: BORSELLINO, N.; MARINARI, A. Leopardi - introduzione all'opera e antologia della critica. Roma: Bulzoni Editore; 1973, p. 66

${ }^{27}$ LUCCHESI, 1996, p. 929

"quis-se considerar minhas opiniões filosóficas como sendo o resultado de meus sofrimentos pessoais, e que se obstina em atribuir às minhas circunstâncias materiais aquilo que se deve se não ao meu entendimento. Antes de
} 
Mas para Timpanaro não se deve negar o reflexo da patologia na gênese da Weltanschauung ${ }^{28}$ leopardiana, tornando o pessimismo puramente "espiritual" ou puramente “político-social”. Para o estudioso:

Bisogna invece riconoscere che la malattia dette al Leopardi una coscienza particolarmente precoce ed acuta del pesante condizionamento che la natura esercita sull'uomo, dell'infelicità dell'uomo come essere físico [...] E quindi l'approfondimento di questo tema doveva prevalentemente orientare il pessimismo del Leopardi in senso 'cosmico'. 29

Com base nos novos escritos (Operette morali), Leopardi foi acusado de se opor totalmente ao espírito do século, negando tanto a religião, quanto o progresso. A necessidade de responder às acusações de apolitismo e de egocentrismo, Timpanaro acredita ter sido o estímulo para a retomada polêmica e combativa no novo titanismo do último Leopardi.

Nessa última fase, para o estudioso, a experiência demonstrou ao poeta que, em sua época atual, o vazio da ignorância não foi preenchido pelas galhardas e magnânimas ilusões dos primitivos, mas pelo híbrido conúbio das deprimentes superstições medievais com um progressismo superficial e falso, incapaz de dar a felicidade ao homem. Em um segundo momento, Leopardi faz um apelo à solidariedade de todos os homens contra a natureza, desenvolvendo um "pessimismo agonístico".

Mais adiante, em 1969, Natalino Sapegno, após um breve estudo sobre a crítica leopardiana, denuncia a perda de coerência da parte dos críticos ao não considerarem a continuidade e a íntima coerência de um itinerário poético de Leopardi, o qual apresenta desde o início, e na sua fase idílica, os elementos de seu amadurecimento. Por sua vez, para o crítico, não se compreende plenamente esse amadurecimento, se não no êxito final. Sapegno acredita que, por mais que a crítica dos últimos anos tenha se modificado (Binni - Luporini - Timpanaro), ela tem

morrer vou protestar contra essas invenções de fraqueza e da vulgaridade, e pedir aos meus leitores para destruírem minhas observações e meus raciocínios antes do que acusar meus males.” [Trad. nossa]

${ }^{28}$ Weltanschauung: compreensão geral do universo e da posição nele ocupada pelo homem que se expressa por um conjunto mais ou menos integrado de representações e que deve determinar, em última instância, a vontade e os atos de seu portador. (Sin. visão de mundo)

${ }^{29}$ TIMPANARO, In: BORSELLINO; 1973, p.67.

Deve-se, no entanto, reconhecer que a doença deu a Leopardi uma consciência particularmente precoce e aguda do pesado condicionamento que a natureza exercita sobre o homem, da infelicidade do homem como ser físico [...] E, portanto, o aprofundamento deste tema deveria de forma prevalente orientar o pessimismo do Leopardi no sentido 'cósmico'. [Trad. nossa] 
insistido excessivamente sobre o componente iluminista, além de ter aceitado muito facilmente o esquema de oposição entre o classicismo e o romantismo, invertendo assim a avaliação tradicional. Sapegno continua:

Solo da un riesame integrale della formazione umana e culturale del Leopardi, che tenga conto di tutti i dati, anche psicologici, della sua personalità e di tutte le componenti che vi confluiscono, [...] sarà possibile, io penso, ritrovare i fondamenti di un'interpretazione e di un giudizio non puramente polemico, ma storico, e cioè articolato e capace di riflettere tutte le sfumature, e magari le contraddizioni, di un'esperienza reale. $^{30}$

Outro crítico a denunciar a tendência da história da crítica leopardiana em separar a poesia da filosofia; a imaginação da teoria; a língua do pensamento de Leopardi, foi Antonio Prete. Em sua obra intitulada Il pensiero poetante $(1980)^{31}$ - livro que, pela primeira vez na história da crítica, foi dedicado inteiramente ao Zibaldone ${ }^{32}$ - o autor critica essa tendência em separar a "lettera" (letra) do "spirito" (espírito), que acaba formando dois percursos paralelos para a compreensão de uma escritura como aquela de Leopardi: de um lado os críticos literários, os quais levam em consideração o Leopardi-lírico; de outro lado os filósofos, os quais se dedicam ao Leopardi-filósofo (2006, p.66).

Prete é a favor de um acostamento entre esses dois confins, para isso faz uso das trilhas presentes na floresta do Zibaldone, trilhas em que se apresenta e discute uma teoria da relação entre filosofia e literatura, assim como são apresentadas pelo próprio Leopardi.

Para Leopardi, conforme o estudioso, a poesia e a filosofia caminham juntas à imaginação. No Zibaldone [1833], Leopardi diz:

Chi non ha mai avuto immaginazione, sentimento, capacità di entusiasmo, di eroismo, d'illusioni vive e grandi, [...] chi non legge o non sente, o non ha mai letto o sentito i poeti, non può assolutamente essere un grande, vero e perfetto filosofo, anzi non

\footnotetext{
${ }^{30}$ SAPEGNO, N. “Giacomo Leopardi”, in: Storia della letteratura italiana, Milano: Garzanti, 1969, p.820.

"Somente por meio de um reexame integral da formação humana e cultural de Leopardi, que leve em conta todos os dados, até mesmo psicológicos, a sua personalidade e todos os componentes que nela confluem, [...] será possível, penso eu, reencontrar os fundamentos de uma interpretação e de um julgamento não puramente polêmico, mas histórico, e, portanto, articulado e capaz de refletir todas as nuanças, e talvez as contradições, de uma experiência real." [Trad. nossa]

${ }^{31}$ PRETE, A. Il pensiero poetante. Saggio su Leopardi. Milano: Feltrinelli, 1980. (Prima edizione ampliata, in: Universale Economica - Saggi - 2006)

${ }^{32}$ Conforme afirma Prete em uma entrevista dada a Andréia Guerini e Patricia Peterle ("Il grande classico è una costante presenza" In: Mosaico Italiano - : L'infinito mondo di Leopardi. Rio de Janeiro: Editora Comunità; n. 66, giugno/2009, pp. 39-40).
} 
sarà mai se non un filosofo dimezzato, [...]; non conoscerà mai il vero, si persuaderà e proverà colla possibile evidenza cose falsissime ec. ec. [...]. La più fredda ragione benchè mortal nemica della natura, non ha altro fondamento nè principio, altro soggetto di meditazione speculazione ed esercizio che la natura. Chi non conosce la natura, non sa nulla, e non può ragionare, per ragionevole ch'egli sia. Ora colui che ignora il poetico della natura, ignora una grandissima parte della natura, anzi non conosce assolutamente la natura, perchè non conosce il suo modo di essere ${ }^{33}$. (4 Ottobre 1821)

Com base na ideia apresentada, Antonio Prete acredita que o desaparecimento da relação entre a razão e a natureza e o abandono do poético são a conotação de uma filosofia que se apresenta como fria projeção da razão.

Por mais que a natureza e a razão estejam em polos opostos, para Leopardi, a razão depende da natureza, pois conhecer a natureza quer dizer também conhecer o poético da natureza. Portanto, sem imaginação e paixão, o conhecimento é impossível: deve-se ter, como Prete afirma, um encontro entre a "poesia pensante" e o "pensare poetante".

Como visto, por meio desse breve balanço apresentado sobre a crítica leopardiana, há um tempo considerável a crítica vem posicionando-se ora com antipatia, ora com simpatia diante do pensamento de Leopardi.

Ao longo desta pesquisa serão analisados quatros poemas leopardianos que se acredita demonstrarem cada um, uma fase de seu pessimismo. Essa divisão do pensamento leopardiano em fases foi seguida por muitos críticos ao longo da história, e continua ainda sendo utilizada em muitos manuais escolares, como por exemplo, em Salinari \& Ricci $^{34}$ (1993); Luperini \& Cataldi ${ }^{35}$ (1997); Ferroni et al. ${ }^{36}$ (2003) entre outros, por seu valor didático. Acredita-se que tal divisão

\footnotetext{
33 "Quem nunca teve imaginação, sentimento, capacidade de entusiasmo, de heroísmo, de ilusões vivas e grandes [...]; quem não lê, ou não sente, ou nunca leu ou não sentiu os poetas, não pode absolutamente ser um grande, verdadeiro e perfeito filósofo, pelo contrário não será nunca se não um filósofo reduzido à metade, [...]; não conhecerá nunca a verdade, persuadir-se-á e provará com a possível evidência coisas falsíssimas etc. etc. [...]. A mais fria razão mesmo se mortal inimiga da natureza, não tem outro fundamento nem princípio, outro sujeito de meditação especulação e exercício do que a natureza. Quem não conhece a natureza, não sabe nada, e não pode raciocinar, por mais racional que seja. Agora, aquele que ignora o poético da natureza, ignora uma grandíssima parte da natureza, aliás, não conhece absolutamente a natureza, porque não conhece o seu modo de ser." (4 de outubro de 1821) [Trad. nossa]

${ }^{34}$ SALINARI, C.; RICCI, C. Storia della letteratura italiana. Con antología degli scrittori e dei critici. Roma: Edizione Laterza, V. $3^{\circ}$ - L'Ottocento, 1993

${ }^{35}$ LUPERINI, R.; CATALDI, P.; MARCHIANI, L.; La scrittura e l'interpretazione - Storia e antologia della letteratura italiana nel quadro della civiltà europea. Firenze: Palumbo; Vol. 4; Tomo secondo; 1997.

${ }^{36}$ FERRONI, G. et alii. Storia e testi della letteratura italiana: restaurazione e risorgimento (1815-1861). Milano: Mondadori Università, 2003.
} 
tenha sentido, pois ilustra movimentos do pensamento e da vida interior do poeta, tendo utilidade para falar da poesia de Leopardi.

Os poemas a serem analisados serão:

Il passero solitario: canto que apresenta uma visão juvenil em que o eu-lírico prevê no futuro um sentimento de remorso, pois perceberá não ter aproveitado a melhor fase da vida: a juventude, tendo passado-a na solidão, fugindo dos prazeres da primavera, ou seja, da juventude, que são os prazeres que o poeta acredita serem aproveitados pelos outros jovens. Nesse poema, é possível identificar a fase do "pessimismo individual" de Leopardi, em que ele descreve o seu não se encaixar no ambiente nativo, vendo-se excluído da joia de viver.

L'infinito: poema dedicado ao poder da imaginação, que se libera graças a um obstáculo que impede a vista do horizonte: uma sebe. Desse modo, por meio dos sentidos, o eu-poetante transcende o real, movendo-se na imensidão e atingindo, assim, com a visão interior, um infinito espacial. É graças a esse afogar-se no pensamento, que o eu-poetante consegue encontrar um conforto dos males. Aqui o pessimismo leopardiano pode ser definido histórico, já que ser feliz não depende mais da vontade do homem; inevitavelmente a história o encaminha ao seu destino de infelicidade. É somente por meio da imaginação que o homem conseguirá criar um alento ao seu viver.

Canto notturno di un pastore errante dell'Asia: esse canto aborda o mistério da natureza e da existência. Representa um homem simples que contempla a natureza, meditando, mesmo não sendo um filósofo, com um tom sereno. Indaga à Lua sobre os porquês da vida, tocando assim os temas mais cruéis, mas de uma forma resignada. Percebe-se nesse poema o "pessimismo cósmico" leopardiano: não só o homem é infeliz, mas, como afirma no Zibaldone, todos os seres animados e inanimados, o mundo, o cosmo em sua totalidade são infelizes.

La ginestra, o il fiore del deserto: canto símbolo da solidariedade humana. O homem, privado de suas ilusões, diante da onipotente força da natureza, deve aceitar racionalmente a realidade, o seu destino. Nessa última fase de Leopardi, vê-se o "pessimismo heroico": em vez dos homens se desgastarem em inúteis guerras fratricidas, o poeta os exorta - visto que estão 
destinados à mesma sorte - a seguirem valores como a concórdia e a fraternidade, encarando assim heroicamente e dignamente seus cruéis destinos.

Em uma passagem do livro Giacomo Leopardi: Poesia e Prosa, Marco Lucchesi (1996, p.11) considera Leopardi um homem solitário diante de sua dolorosa solidão. Mas quão contraditório é o fruto dessa solidão que atraiu e continua atraindo uma grande quantidade de pessoas, desejosas de instaurar um diálogo com o autor por meio da leitura de suas obras. Numerosos são os estudos dedicados às obras de Leopardi, comprovando o interesse que o autor e sua obra continuam despertando perante o público.

Esse jogo de oposição, voluntário ou não, parece acompanhar Leopardi. Benedetto Croce, em sua obra já citada Poesia e non poesia já se questionava sobre os contrastes presentes em composições poéticas de Leopardi:

Perché [...] non bisogna lasciarsi fermare dalla somma correttezza e proprietà ed eleganza con la quale la poesia del Leopardi si presenta, ma guardare in là e osservare che sotto quella irreprensibilità letteraria se non si avverte mai vuoto nel pensare e nel sentire, nondimeno, poeticamente, si ritrova ora il forte ora il fiacco, ora il pieno e ora il lacunoso, e affermare che la poesia del Leopardi è assai più travagliata di quanto non si sospetti o di quanto non si creda. C'è in essa dell'arido, c'è della prosa, c'è del formalmente letterario, e c'è insieme poesia dolcissima e purissima e armoniosissima; $[\ldots]^{37}(1923, \mathrm{p} .119)$

Da mesma forma deve-se considerar o pessimismo leopardiano. Compartilhando o pensamento de Lucchesi, acredita-se que seja incorreto usar o conceito de pessimismo presente nos escritos leopardianos sem compreender-lhe o heroico estoicismo. Por esse motivo, escolheuse analisar quatro poemas que demonstrem as fases do pessimismo leopardiano.

A produção lírica de Giacomo Leopardi está toda publicada no livro dos Canti. A presente pesquisa basear-se-á nas seguintes edições:

\footnotetext{
37 'Porque [...] não necessita deixar-se parar pela extrema exatidão, propriedade e elegância com as quais a poesia de Leopardi se apresenta, mas olhar para lá e observar que, debaixo daquela irrepreensibilidade literária, se não se sente nunca um vazio ao pensar e sentir, não obstante, em forma poética, encontra-se ora o forte ora o fraco, ora o completo e ora o lacunoso, e afirmar que a poesia de Leopardi é muito mais atormentada do que se suspeita ou se acredita. Há nela algo árido, há prosa, há alguma coisa formalmente literária, e há ao mesmo tempo poesia dulcíssima, puríssima e muito harmoniosa [...]" [Trad. LUCCHESI, 1996, pp. 54-55]
} 
- Edição italiana organizada por Emilio Peruzzi, intitulada Giacomo Leopardi Canti; editada, pela primeira vez, pela Biblioteca Universale Rizzoli no ano de 1981, sendo a segunda edição datada no ano de 1998 - Escolheu-se tal edição para a análise estilística dos poemas, pois apresenta inicialmente o texto completo de cada canto, representando a última edição corrigida e revisada pelo autor, para em seguida reproduzir, em ordem cronológica, os autógrafos e as edições aprovadas pelo autor, em modo a demonstrar as modificações feitas pelo poeta.

- Edição brasileira organizada por Marco Lucchesi, intitulada Giacomo Leopardi: Poesia e prosa, com notas e prefácio do organizador, apresentando traduções de Affonso Félix de Sousa... et al., editada pela Nova Aguiar no ano de 1996. Grande parte das obras de Leopardi está reunida nessa edição na versão em língua portuguesa, que é considerada de grande importância por representar uma via de entrada às obras do poeta italiano para aqueles leitores que não têm acesso às obras "originais". Esse foi o motivo que guiou a escolha dessa edição para se fazer o cotejo entre os poemas escolhidos e suas respectivas traduções. Ao longo deste trabalho, serão feitas muitas citações leopardianas, para isso utilizar-se-á as traduções de tais passagens, se constantes na obra de Marco Lucchesi, caso contrário, propor-se-á a nossa tradução.

Os poemas escolhidos serão apresentados em língua italiana e ao seu lado serão reportadas as versões traduzidas em português por poetas brasileiros, como Ivan Junqueira, Ivo Barroso, José Paulo Paes e Affonso Félix de Sousa, recolhidas por Lucchesi no livro citado. O intuito desta pesquisa é fazer uma análise estilística dos poemas escolhidos, paralelamente discutindo os pontos mais críticos das traduções apresentadas. Sendo assim, as análises serão feitas em língua portuguesa do Brasil, com base nos poemas em língua original - tratando-se da área a que nos dedicamos em nossa formação. 
Para comodidade do leitor, apresenta-se um cronograma da vida e das principais obras de Giacomo Leopardi até o ano de sua morte:

1798: no dia 29 de junho, nasce Giacomo Taldegardo Francesco Salesio Saverio Pietro Leopardi, em Recanati.

1809-16: período denominado por ele mesmo em: "sette anni di studio matto e disperatissimo"38. Compõe duas tragédias e obras eruditas. Traduz os clássicos.

1816: interessa-se pelas letras italianas e pela poesia. Ano de sua "conversão estética".

1817: no mês de fevereiro, começa a se corresponder com Pietro Giordani; por volta de julho ou agosto, escreve as primeiras anotações daquele que mais tarde será o Zibaldone di pensieri; em dezembro, apaixona-se pela prima Gertrude Cassi Lazzari, dedicando-lhe algumas composições amorosas: Diario del primo amore e Il primo amore.

1818: compõe duas canções civis: All'Italia e Sopra il monumento di Dante. Em maio, escreve o "Discorso di un italiano sopra la poesia romantica".

1819: "conversão filosófica". Ano em que Leopardi é atingido por uma doença nos olhos que o impede de fazer suas prazerosas leituras. Tentativa de fuga de Recanati, descoberta pelo pai. No alto do monte Tabor, escreve dois idílios: L'Infinito e Alla luna.

1820: compõe outra canção civil: Ad Angelo Mai quand'ebbe trovato $i$ libri di Cicerone della Repubblica, além de outros idílios: La sera del di' di festa e Il sogno.

1822: ano em que se transfere para Roma. Compõe nesse período: Alla primavera, o Ultimo canto di Saffo e Inno ai Patriarchi, o de' principi del genere umano.

1823: volta em abril para Recanati. E com Alla sua donna despede-se provisoriamente da poesia.

1824: ano em que compõe as primeiras vinte Operette morali. Em Bolonha, publica as dez primeiras Canzoni.

1825: sai de Recanati e vive entre Bolonha e Florença. Nesse ano começa a trabalhar para o editor milanês Stella.

1826: no verão desse ano, sai a edição bolonhense dos Versi, pela Stamperia delle muse.

1827: faz amizade com Antonio Ranieri em Bolonha. Nesse ano é publicada a primeira edição das Operette morali.

1828-30: Leopardi volta a compor poesias: Il Risorgimento, A Silvia, Le ricordanze, La quiete dopo la tempesta, Il sabato del villaggio e Canto notturno di un pastore errante dell'Asia.

1831: sai a primeira edição dos Canti, publicada pelo editor Piatti, em Florença. Acredita-se que entre 1831 e 1834, após a publicação dessa edição dos Canti, Leopardi tenha escrito o poema Il passero solitario.

1835: o editor Starita publica a segunda edição dos Cant”, em Nápoles, com todos os cantos até então compostos. Nesse mesmo ano é publicada a terceira edição das Operette Morali, tendo a segunda sido publicada no ano precedente, pelo editor Piatti em Florença.

1836: Leopardi compõe La ginestra, o Il fiore del deserto e Il tramonto della luna.

1837: Leopardi morre em Nápoles no dia 14 de junho devido a um ataque de asma e hidropisia cardíaca.

\footnotetext{
${ }^{38}$ Carta a Pietro Giordani, 2 de março de 1818. "Sete anos de estudo louco e desesperado" - [Trad. nossa]
} 


\subsection{O LIRISMO LEOPARDIANO}

\subsection{Classificação dos gêneros da poesia segundo Leopardi}

Leopardi, no Zibaldone (15 Dicembre 1826$)^{39}$, afirma que a poesia pode ser classificada em três grandes divisões: lírica, épica e dramática. A poesia lírica, natural nos homens até mesmo dos mais selvagens, representa o que há de mais nobre e poético. O seu objetivo é o de aportar alento às dores sentidas pelo homem, utilizando-se para tanto de palavras bem medidas e harmoniosas. A poesia épica pode ser considerada uma extensão da poesia lírica, pois foi a partir dela que se desenvolveu. Assim como acontecia nos primeiros poemas líricos, o poema épico também vinha acompanhado da lira e da música, mas o que o diferenciava daquele era a temática abordada: um hino ao herói, à nação ou ao exército. A última das três divisões é a dramática, diferenciando-se das anteriores por não ser expressão livre e sincera de qualquer afeto vivo e bem sentido pelo homem, mas invenção, poesia por convenção e por vontade de seu autor e não por essência. O drama é para Leopardi um espetáculo, filho da civilidade e do ócio, inventado como forma de entretenimento para as pessoas ociosas, desejosas de fazer passar o tempo, inspirado não na natureza, mas inventado pelo engenho do homem. Em suma, para Leopardi, todas as demais classificações existentes quanto ao gênero da poesia podem ser reduzidas às três categorias citadas.

\subsection{A modernidade da poesia leopardiana}

Para Leopardi o lírico é o primeiro de todos os gêneros, dando origem ao épico, ambos próprios da natureza. Sendo o dramático criado pela sociedade, torna-se menos nobre que os demais por ser artificial, ou seja, por usar a razão. Com isso, Leopardi defende uma visão contrária em relação aos classicistas, pois esses defendiam como gêneros mais elevados a tragédia e o épico. Ao eleger o gênero lírico como o primogênito, Leopardi vai contra a hierarquia dos gêneros até então existente, demonstrando a sua modernidade.

\footnotetext{
${ }^{39}$ [4235 - 4236]
} 
Mais adiante, em agosto de 1828, Leopardi volta a ponderar sobre os gêneros poéticos. Na passagem [4356] ele afirma ter o poema épico nascido de um falso pressuposto, sendo ele contra a natureza da poesia, já que é concebido e organizado friamente, levando anos para a sua execução. Dessa forma o poema épico iria contra a natureza da poesia, já que essa tem como característica a brevidade, por nascer de um ímpeto ou impulso da alma. Como poderia então a imaginação, o espírito poético, perdurar por tanto tempo sobre um mesmo argumento, como é o caso do poema épico? Fica evidente, para Leopardi, o esforço de Virgílio em seus últimos seis livros da Eneida, escritos propositalmente e não por impulso da alma; contrariamente ao que ocorre em Orlando Furioso de Ariosto, obra formada por uma sucessão de argumentos diversos, quase que de diversas poesias, o que permitiria ao poeta terminar sua obra no momento que quisesse, mas que continuava por sua espontânea vontade, sem perder o impulso primitivo do canto. Percebe-se então que, para Leopardi, o épico é mais um conjunto de fragmentos líricos do que um gênero distinto ${ }^{40}$.

O poema dramático, para Leopardi [4357], parece pertencer menos ainda à poesia. Por mais que nesse tipo de poema os versos possam ter a forma, não têm a natureza poética, pois perderam a sua essência. No gênero dramático, o poeta finge uma paixão, que de fato não tem. Para Leopardi, um poeta deve expor seus próprios sentimentos, não deve se abandonar e se transformar em outra pessoa. Em suma, o poeta diz que 'L'estro del drammatico è finto, perch'ei dee fingere: un che si sente mosso a poetare, non si sente mosso che dal bisogno d'esprimere de' sentimenti ch'egli prova veramente ${ }^{41,}$.

A modernidade de Leopardi está também na rejeição do conceito de que os gêneros são distintos entre si, inalteráveis e seguidores de regras definidas. Com isso, percebe-se que Leopardi vai contra a ideia clássica de gêneros puros. Para ele, "anche dentro uno stesso genere (come l'epico), si danno mille specie, ed anche mille differenze di forme individuali ${ }^{42, .}$

\footnotetext{
${ }^{40}$ Zib. [4412-13]

41 “O estro do dramático é falso, porque se deve fingir: aquele que se sente movido a poetar, não o é senão pela necessidade de exprimir os sentimentos que ele realmente tem." Zib. [4357] - [Trad. nossa]

42 "até dentro de um mesmo gênero (como o épico) têm-se mil espécies, e também, mil diferenças de formas individuais". [1673] - (11 de setembro de 1821) - [Trad. nossa]
} 
Leopardi considera muito importante para um poeta a capacidade imagética, divergindo daqueles que concebem a arte como imitação da natureza. Para ele, o poeta não imita a natureza, mas é a natureza que fala nele; dessa forma, o poeta não é um imitador se não dele mesmo. Mas, se ele imita algo, abandonando a sua essência, o resultado não é mais poesia, faculdade divina, mas arte humana, prosa, não obstante o verso e a linguagem ${ }^{43}$. O poeta deve, portanto, imitar a ele mesmo, deve expor seus próprios sentimentos, aproximando-se assim da lírica; e não imitar o que não lhe é natural, como é o caso da dramática.

\subsection{A importância do gênero lírico para Leopardi}

Quanto à importância da lírica em relação aos demais gêneros, Leopardi na passagem [245] do Zibaldone diz: "La lirica si può chiamare la cima il colmo la sommità della poesia, la quale è la sommità del discorso umano",44.

Percebe-se então que a lírica é o gênero por excelência para Leopardi. Além de apresentar maior espontaneidade e proximidade à expressão da natureza do que os demais gêneros, para o poeta, o poema lírico é imbuído de simplicidade, clareza e concisão, dando voz a sensações indeterminadas, vagas, infinitas, da memória, da lembrança, que são características que se destacam nos poemas de Leopardi, como se verá nas análises apresentadas nesse trabalho.

Em relação à simplicidade, no Zibaldone [1411-12], discursando sobre as belas-artes, Leopardi diz:

La semplicità è quasi sempre bellezza sia nelle arti, sia nello stile, sia nel portamento, negli abiti ec. ec. ec. Il buon gusto ama sempre il semplice [...] perchè suol esser propria della natura, [...] La semplicità è bella, perchè spessissimo non è altro che naturalezza; cioè si chiama semplice una cosa, non perch'ella sia astrattamente e per se medesima semplice, ma solo perchè è naturale, non affettata, non artifiziata, semplice in quanto agli uomini, non a se stessa, e alla natura ec ${ }^{45}$. (30 Luglio 1821)

\footnotetext{
${ }^{43} \mathrm{Zib}$, [4372-3], 10 de setembro de 1828.

44 "Pode-se chamar a lírica de cima de cume, de sumidade da poesia, a qual é a sumidade do discurso humano"[Trad. nossa]

45 “A simplicidade é quase sempre beleza seja nas artes, seja nos estilos, seja no comportamento, nos hábitos etc. etc. etc. O bom gosto ama sempre o simples [...] porque costuma ser próprio da natureza, [...]. A simplicidade é bela, porque muito frequentemente nada mais é do que naturalidade; ou seja, chama-se simples uma coisa, não porque seja
} 
Elegendo a simplicidade como um dos elementos importantes para a poesia, Leopardi se aproxima dos antigos, distanciando-se daqueles que em seu tempo valorizavam o complexo e a não clareza.

A recordação, para Leopardi, é outro elemento importante para a poesia. Por meio da lembrança é possível retornar ao sentimento poético inexistente no presente. Na passagem [4426], ele diz:

"La rimembranza è essenziale e principale nel sentimento poetico, non per altro, se non perchè il presente, qual ch'egli sia, non può esser poetico; e il poetico, in uno o in altro modo, si trova sempre consistere nel lontano, nell'indefinito, nel vago ${ }^{46} . "(14$ Dicembre 1828)

Para se expressar o poético, não são necessárias extenuantes divagações e Leopardi é a favor da concisão, pois, como já visto, a poesia tem como característica a brevidade. Na passagem [2041-42] Leopardi afirma:

La rapidità e la concisione dello stile, piace perchè presenta all'anima una folla d'idee simultanee, o così rapidamente succedentisi, che paiono simultanee, e fanno ondeggiar l'anima in una tale abbondanza di pensieri, o d'immagini e sensazioni spirituali, ch'ella o non è capace di abbracciarle tutte, e pienamente ciascuna, o non ha tempo di restare in ozio, e priva di sensazioni ${ }^{47}$. (3 Novembre 1821)

Entre os três gêneros principais de poesia, para Leopardi aquele que realmente resta aos modernos é o lírico, o qual é eterno e universal, próprio do homem de todos os tempos e de todos os lugares, que quase se confunde com a própria poesia ${ }^{48}$.

abstratamente e por si só simples, mas somente porque é natural, não afetada, não artificializada, simples em quanto aos homens, não a si mesma, e à natureza etc." (30 de julho de 1821) - [Trad. nossa]

46 “A recordação é essencial e principal no sentimento poético, não por nada, se não porque o presente, qualquer que seja, não pode ser poético; e o poético, de um modo ou do outro, consiste sempre no longínquo, no indefinido, no vago." (14 de dezembro de 1828) - [Trad. nossa]

47 "A rapidez e a concisão do estilo agrada porque apresenta à alma uma multidão de ideias simultâneas, ou sucedidas tão rapidamente que parecem simultâneas, e fazem ondear a alma em tamanha abundância de pensamentos, ou de imagens e sensações espirituais, que ela ou não é capaz de abraçá-las, todas e plenamente cada uma, ou não tem tempo de permanecer no ócio, e privada de sensações." (30 de novembro de 1821) - [Trad. nossa]

${ }^{48}$ Zib. [4476]; 29 de março de 1829. 
Segundo Natalino Sapegno, não se deve confundir o sentido que Leopardi da à palavra "lírica" com aquele moderno que inclui qualquer forma de poesia. Portanto, para compreender a poética leopardiana, deve-se levar em consideração que:

A lírica é o canto que não conhece duração, nem regra, nem ordem, tirando a sinceridade da inspiração; que exprime o palpitar do coração na sua imediatidade e "momentaneidade"; é a voz pura e simples do sentimento, que não conta e tanto menos apresenta (não imagina tramas, nem cria personagens em um ambiente fictício inventado), somente diz, de modo liberal sincero, as suas penas e as suas jóias no mesmo instante em que as sente ${ }^{49}$.

Para Carducci, poeta italiano, os anos entre 1815 e 1850 representaram a verdadeira estação lírica italiana, desde o período medieval, com Dante e Petrarca. Em um dos primeiros estudos dedicados a Giacomo Leopardi, mais precisamente no ensaio Degli spiriti e delle forme nella poesia di Giacomo Leopardi. Considerazioni, Carducci diz:

“Dal 1815 dunque al '50 l'Europa ebbe la più larga fioritura lirica che mai; e il maggio fu

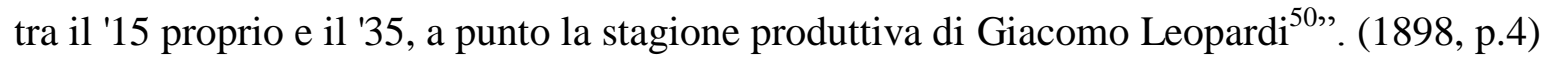

Como se percebe, as obras leopardianas foram de grande importância para a consolidação do gênero lírico na história literária.

Outro crítico a perceber a importância de Leopardi quanto ao panorama histórico dos gêneros literários foi Francesco De Sanctis. Em sua obra intitulada Storia della letteratura italiana (1870, p.396), mais precisamente no capítulo La nuova letteratura, De Sanctis faz referência a uma divisão entre a "vecchia letteratura" (velha literatura) e a "nuova letteratura" (nova literatura) e é com Leopardi que se tem o início da "nova literatura", anunciando o fim de uma tendência teológica-metafísica na literatura para dar andamento ao "regno dell'arido vero, del reale" - (reino do verdadeiro árido, do real). De Sanctis afirma ainda que, a partir de Leopardi, a literatura:

\footnotetext{
${ }^{49}$ SAPEGNO, N. In: BALBONI, 2004, p. 164.- [Trad. nossa]

50 "Portanto, de 1815 a 1850 a Europa teve a mais ampla florescência da lírica do que nunca; e maio [mês da floração das plantas na Itália] foi entre '15 e '35, a estação produtiva de Giacomo Leopardi' - [Trad. nossa]
} 
rigetta le classi, le distinzioni, i privilegi [...] Il contenuto non si spicca dalla forma. Non ci è che una cosa, il vivente. Dal seno dell'idealismo comparisce il realismo nella scienza, nell'arte, nella storia. È un'ultima eliminazione di elementi fantastici, mistici, metafisici, rettorici. La nuova letteratura, rifatta la coscienza, acquistata una vita interiore, emancipata da involucri classici e romantici, eco della vita contemporanea universale e nazionale, come filosofia, come storia, come arte, come critica, intenta a realizzare sempre più il suo contenuto, si chiama oggi ed è la letteratura moderna ${ }^{51}$. (1890, p.463)

Por meio de seu lirismo, Leopardi lamenta a intempestividade da poesia no mundo moderno (século XIX), pois, em um período onde predomina a ganância, as pessoas tornam-se rivais, proporcionando o acentuar do isolamento. Tudo isso contribui ao desinteresse em relação ao lirismo. Tal pensamento é ainda discutido hoje, conforme se percebe em Bosi (2004, p.131):

"Egoísmo e abstração geram modos de sentir, agir e falar muito distantes das condições em que se produz a poesia: que é exercício próprio da empatia, das semelhanças, da proximidade."

As ideias leopardianas sobre a poesia têm uma profunda ligação com os aspectos essenciais da sensibilidade contemporânea. Para Leopardi, a poesia torna-se um instrumento de autoconhecimento, e é por meio dela que o poeta expressa seus sentimentos. Dessa forma, a poesia passa a ter uma função mediadora entre o mais puro eu do poeta e o mundo, tornando o sentimento do eu-lírico porta-voz da condição existencial do homem.

Leopardi tinha a consciência de que cada palavra poderia criar um efeito psicológico no leitor, podendo comovê-lo ou agitá-lo. No Zibaldone [3139], Leopardi diz que a leitura de um poema desperta na alma do leitor:

quel vivo contrasto di passioni e di sentimenti, [...] e cagiona nell'animo de' lettori una tempesta, un impeto, un quasi gorgogliamento di passioni che lascia durevoli vestigi di se, e in cui principalmente consiste il diletto che si riceve dalla poesia, la quale

\footnotetext{
51 “rejeita as classes, as distinções, os privilégios [...] O conteúdo não se destaca da forma. Não existe que uma coisa, o vivente. Do seio do idealismo aparece o realismo na ciência, na arte, na história. É uma última eliminação de elementos fantásticos, místicos, metafísicos, retóricos. A nova literatura, refeita a consciência, adquire uma vida interior, emancipada de invólucros clássicos e românticos, eco da vida contemporânea universal e nacional, como filosofia, como história, como arte, como crítica, intenta a realizar sempre mais o seu conteúdo, chama-se hoje e é a literatura moderna." - [Trad. nossa]
} 
ci dee sommamente muovere e agitare e non già lasciar l'animo nostro in riposo e in calma $^{52}$. (5-11 agosto 1823$)$

Interessante é essa ideia de que a leitura de um poema deve produzir na alma do leitor uma tempestade. Pensamento análogo é possível encontrar em Franz Kafka, quando, em 1904, escreve uma carta a seu amigo Oskar Pollack, em que exprime uma ideia de literatura muito próxima àquela de Leopardi. Assim ele dizia em um trecho dessa carta:

Se o livro que estamos lendo não nos desperta com um murro na cabeça, por que então o lemos? Para que ele nos torne felizes [...]? Oh Deus, seriamos felizes do mesmo modo, até sem livros, livros que nos fazem felizes, esses, quando necessário, poderíamos escrevê-los nós mesmos [...]. Um livro deve ser um machado para o mar congelado que está dentro de nós. Disso tenho convicção.” (1988, p.27) - [Trad. nossa]

Trata-se de uma ideia de literatura muito forte, de tipo dramática. A literatura e a arte em geral devem, portanto, conforme a visão de Kafka, produzir no leitor um trauma de ordem psíquico, que interrompa de modo repentino o fluxo da vida e o andamento do quotidiano. Dessa forma, tem-se, na consciência do leitor, um antes e um depois de se ter lido uma obra.

Outra passagem do Zibaldone em que Leopardi deixa claro o seu posicionamento em relação ao efeito que a leitura de uma obra deve causar no leitor é a [4274], em que diz:

[...] quando talvolta per ozio, mi son posto a leggere qualche libro per semplice passatempo, ed a fine solo ed espresso di trovar piacere e dilettarmi; non senza maraviglia e rammarico, ho trovato sempre che non solo io non provava diletto alcuno, ma sentiva noia e disgusto fin dalle prime pagine. E però io andava cangiando subito libri, senza però niun frutto; finchè disperato, lasciava la lettura, con timore che ella mi fosse divenuta insipida e dispiacevole per sempre, e di non aver più a trovarci diletto: il quale mi tornava però subito che io la ripigliava per occupazione, e per modo di studio, e con fin d'imparare qualche cosa, o di avanzarmi generalmente nelle cognizioni, senza alcuna mira particolare al diletto. Onde i libri che mi hanno dilettato meno, e che perciò da qualche tempo io non soglio più leggere, sono stati sempre quelli che si chiamano come per proprio nome, dilettevoli e di passatempo ${ }^{53}$. (6 Aprile 1827)

\footnotetext{
52 "aquele vivo contraste de paixões e de sentimentos [...] e produz na alma dos leitores uma tempestade, um ímpeto, um quase gorgolejamento de paixões que deixam duradouros vestígios de si, em que principalmente consiste o deleite que se recebe da poesia, a qual deve principalmente mover e agitar e não deixar a nossa alma em repouso, e na calmaria" (5-11 de agosto de 1823) - [Trad.nossa]

53 “"...] quando às vezes por ócio, me propus a ler algum livro por simples passatempo, com o fim somente e expresso de encontrar prazer e deleitar-me; não sem maravilha e amargura, percebi sempre que não só eu não provava deleite algum, mas sentia um tédio e desgosto já das primeiras paginas. E, todavia, eu ia mudando subitamente de livros, sem, porém, nenhum fruto; até quando desesperado, deixava a leitura, com temor que ela virasse insípida e desprazível para sempre, e de não encontrar mais deleite: o qual me voltava logo que eu a retomasse por ocupação, e por estudo, e com o fim de aprender alguma coisa, o de me acrescentar geralmente nas
} 
A literatura, conforme acima, não tem como função principal proporcionar prazer, mas introduzir na vida do leitor um elemento de conhecimento. A literatura cria, então, uma relação subjetiva entre o leitor e o texto. Dessa forma, ela proporciona um maior e mais profundo autoconhecimento.

Conforme a opinião dos dois autores citados, a leitura de uma obra de arte, feita somente por prazer, em busca da felicidade, seria uma experiência superficial, pois além de não representar um trauma psíquico, também não representa nenhuma experiência significativa em sua vida.

Como visto, para Leopardi, a poesia lírica é a mais espontânea entre as demais, por ser originada do coração e da alma, e por isso o gênero lírico é o mais apto a acolher a voz dos reais sentimentos do poeta, “dando voz às sensações mais indefinidas e incapturáveis, não fixadas em desenhos corpulentos e em limites precisos; o seu âmbito é aquele do vago, do indeterminado, do infinito, da memória e da recordação ${ }^{54}$."

Em relação à presença da poesia nos tempos atuais, Leopardi diz [726-27]:

La forza creatrice dell'animo appartenente alla immaginazione, è esclusivamente propria degli antichi. Dopo che l'uomo è divenuto stabilmente infelice, [...]e dopo che il mondo è divenuto filosofo, l'immaginazione veramente forte, verde, feconda, creatrice, fruttuosa, non è più propria se non de' fanciulli [...]. La forza di un tal animo ogni volta che si abbandona all'entusiasmo (il che non è più così frequente) si rivolge all'affetto, al sentimento, alla malinconia, al dolore [...] La poesia sentimentale è unicamente ed esclusivamente propria di questo secolo, come la vera e semplice (voglio dire non mista) poesia immaginativa fu unicamente ed esclusivamente propria de' secoli Omerici, o simili a quelli in altre nazioni. Dal che si può ben concludere che la poesia non è quasi propria de' nostri tempi, e non farsi maraviglia, s'ella ora langue come vediamo, e se è così raro non dico un vero poeta, ma una vera poesia ${ }^{55 \%}$. (8 Marzo 1821)

cognições, sem alguma mira ao deleite. Nos livros que me deleitaram menos, e que por isso há algum tempo eu não costumo mais ler, foram sempre aqueles que se chamam como o próprio nome diz, deleitável e de passatempo.”(6 de abril de 1827) - [Trad. nossa]

${ }^{54}$ FERRONI, 2003, p. 87.

55 “A força criadora do espírito concernente à imaginação pertence exclusivamente aos antigos. Depois que o homem se tornou habitualmente infeliz, [...] e depois que o mundo se tornou filósofo, a imaginação realmente forte, verde, fecunda, criadora, frutuosa resultou própria de crianças [...]. A força de um espírito como esse, todas as vezes que se abandona ao entusiasmo (o que não é mais tão frequente), volta-se para o afeto, para o sentimento, para a melancolia, para a dor. [...] A poesia sentimental é única e exclusivamente própria deste século, como a poesia imaginativa verdadeira e simples (isto é, pura) foi única e exclusivamente própria dos séculos de Homero, ou dos que lhe foram semelhantes em outras nações. Do que se pode concluir que a poesia já não é tão própria de nossos temos e não se 
Em suma, em uma época em que o homem está distante da natureza e dominado pelo conhecimento, e por isso incapaz de sentir, fantasiar ou se iludir, só lhe resta dar voz aos seus sentimentos - lamuriantes em relação ao entusiasmo perdido. Para isso, segundo Leopardi, o gênero lírico se faz mais apropriado ao homem moderno, por acolher a verdadeira voz do sentimento do poeta.

admire se ela está enfraquecida, conforme observamos, e se é tão raro, não digo um verdadeiro poeta, mas uma verdadeira poesia." (8 de março de 1821) - [Trad. LUCCHESI, 1996, pp. 571-574] 


\subsection{CONSIDERAÇÕES SOBRE A INTERPRETAÇÃO DE UM TEXTO POÉTICO E DE SUA TRADUÇÃO}

\subsection{Diálogo entre a língua e a literatura: análise interpretativa de poemas}

O presente trabalho tem como objetivo inicial fazer um estudo interpretativo de alguns poemas de Giacomo Leopardi, por meio da análise da relação do plano da expressão e do plano do conteúdo. Para isso, far-se-á uso da estilística, que tem como enfoque os valores expressivos do texto. Cada detalhe, seleção verbal, ordem na frase, traços evocativos lexicais, recorrência sonora, entre outros elementos presentes no texto, colaboram com a formação de sentido.

Ao relacionar o plano da expressão com o do conteúdo, recorre-se a Ulmann (1970, p.23) o qual aproxima a estilística à semântica:

A aparição, desde os primeiros anos deste século, de uma nova ciência da estilística, teve uma influência profunda nos estudos semânticos. Falando em termos gerais, a estilística diz respeito aos valores expressivos e evocativos da linguagem. A nova disciplina sofreu grande avanço nos últimos anos, relacionando-se especialmente com a semântica. Demonstrou-se que todos os grandes problemas da semântica têm implicações estilísticas, e em alguns casos, como por exemplo no estudo das tonalidades emotivas, as duas orientações estão inextricavelmente entrelaçadas ${ }^{56}$.

Importante é esclarecer que o sentido a que se chegará, por meio das interpretações dos poemas de Leopardi, não é necessariamente o pensamento do autor-produtor do texto, ou, como define Umberto Eco, do autor empírico, mas será reflexo de sugestões provocadas pela leitura do texto no leitor-receptor, que é também empírico.

Todavia, não se deve pensar em uma total liberdade de interpretações em relação a um texto por parte do leitor, pois como defende Riffaterre (1973, p.42) um texto apresenta elementos que limitam o processo de decodificação, portanto, “os julgamentos de valor do leitor são provocados por um estímulo que está no texto.”

\footnotetext{
${ }^{56}$ MOLITERNO, I. de A. Imagens, reverberações na poesia de Alberto da Cunha Melo: uma leitura estilística”. FFLCH / USP. Tese de doutorado, 2007, p.19
} 
Umberto Eco, em seu livro intitulado Obra aberta (1962, p.39), em relação às diferentes interpretações que se pode dar a um texto, leva em consideração a "abertura" que tal texto proporciona ao leitor, como é o caso, por exemplo, da durabilidade da mensagem: que nunca se esgota, permanecendo fonte de informações e respostas às possíveis indagações surgidas de diversos tipos de sensibilidade e cultura, que se renovam nos diferentes períodos de tempo.

Para se fazer uma análise de uma obra, deve-se, então, levar em consideração também a "abertura" que ela oferece. Em um poema, por exemplo, cada estrofe, verso ou até mesmo cada palavra pode remeter a uma multiplicidade de significados. Cabe ao leitor encontrar a chave de leitura para conseguir decifrar a mensagem intrínseca, bem como preencher os vazios (espaços em branco - não ditos) presentes no texto.

Fazendo uso da terminologia bakhtiniana, o leitor tem uma "atitude responsiva ativa", ele pode concordar, discordar, adaptar, e até mesmo completar um texto no momento em que $1 \hat{e}^{57}$. Dependendo de seu estado de ânimo, uma releitura da obra poderá lhe parecer diferente do primeiro contato que tivera com ela, todavia isso não significa, como já afirmado, uma total liberdade de interpretação. Para Eco (1986) o autor, no momento em que cria o seu texto, faz certas escolhas, de modo a guiar o seu leitor. Este, imaginado pelo autor, define-se como leitormodelo.

Sendo assim, uma escolha de expressão por parte do autor ou do leitor, pois esse último também faz escolhas de significação no momento da leitura, pode acarretar em um diferente pensamento correspondente, remetendo a outro sentido, que não o pensado pelo escritor.

Um dos papéis da estilística é o de buscar no texto recursos que levem a interpretar as escolhas apresentadas no poema, centralizando o olhar do estudioso no texto e não mais no seu autor. Todavia, a figura do autor não permanece esquecida de tudo, pois o que se instaura aqui é um triângulo de interação, formado por autor - texto - leitor. Conforme já explicado, o autor faz suas escolhas - tanto de palavras como de combinações - no momento da criação de sua obra; o

\footnotetext{
${ }^{57}$ Bakhtin, 1992, p. 289.
} 
efeito estilístico criado no texto é percebido durante a leitura, resultando em uma determinada reação do leitor, podendo ser ela diferente de leitor para leitor.

Para Claudine Fabre, em Lingüística e poesia, com base nos estudos feitos por Jakobson, "a função poética entra em ação quando uma mensagem funciona como um todo: cada elemento é necessário ao conjunto e é a economia do conjunto que condiciona a interpretação de cada elemento ${ }^{58}$."

Para interpretar um poema, deve-se lê-lo em diversas direções: seguir a linearidade do texto, mas também fazer uma leitura tabular, voltando ou avançando no texto. Deve-se procurar a melhor leitura, formulando-se hipóteses de interpretação para serem confirmadas posteriormente.

Tal método de análise está diretamente relacionado ao círculo filológico ${ }^{59}$ de Leo Spitzer, grande estudioso da estilística literária. Inicialmente, por meio de atenta leitura e releitura, o analista deve identificar um traço textual, um elemento que lhe tenha chamado a atenção no texto, algo que se diferencia na obra e represente singularidade, para daí iniciar sua análise. A partir desse desvio, cria-se um ato de fé, hipótese a ser comprovada por meio de relações entre os elementos do texto. Para Spitzer, todo desvio liga-se a um sistema, conduzindo o leitor ao centro/interior da obra. Para comprovar se o desvio encontrado, por meio do subjetivismo, é significativo, aplica-se o círculo: ciclo de leituras, avançando ou retrocedendo, relacionando assim o todo com a parte.

A comprovação ocorre, portanto, porque todos os elementos numa obra estão interligados. Sendo assim, a escolha das palavras por parte do autor não é feita por acaso, pois elas possuem uma relação entre si, o que acaba por guiar o intérprete.

Para explicar a pluralidade de interpretações de uma obra, recorre-se novamente a Eco, o qual faz uma analogia entre um texto e um bosque: "Usando uma metáfora criada por Jorge Luis Borges, [...] um bosque é um jardim de caminhos que se bifurcam. Mesmo quando não existem

\footnotetext{
${ }^{58}$ FABRE, C. "Poesia e Lingüística". In: Grupo francês de Educação Nova. Orientação: COSEM, M. O poder da poesia. Coimbra: Livr. Almedina, 1980.

${ }^{59}$ SPITZER, L. Lingüística e história literária. Madrid: Gredos, 1955.
} 
num bosque trilhas bem definidas, todos podem traçar sua própria trilha, decidindo ir para a esquerda ou para a direita de determinada árvore e, a cada árvore que encontrar, optando por esta ou aquela direção ${ }^{60}$."

Percebe-se então que cada leitor empírico poderá interpretar o texto de forma diferente devido à pluralidade de interpretações que a obra possibilita, já que o texto é como um bosque, onde há várias trilhas e diversos caminhos a seguir, mas não se deve esquecer que existe também o limite do bosque, representando o limite das interpretações de um texto.

Outro fator importante, que não se pode deixar de mencionar, é o contexto histórico e cultural em que estão inseridos tanto o autor quanto o leitor empírico, pois a visão de mundo de cada época impõe restrições e a interpretação de um poema pode mudar ao longo do tempo.

Cada vez que se lê um texto, novas interpretações vão surgindo, pois, segundo Orlandi e Guimarães (1990, p.7), a leitura é produzida em determinadas condições. Quanto à história da leitura nas diferentes épocas, do ponto de vista do leitor com o texto, por exemplo, na Idade Média não podia interpretar o texto que lia, por outro lado, no Romantismo era estimulada a interpretação pessoal. Com isso chega-se a diversas interpretações que um texto pode ter, desde que venham comprovadas por meio de recursos presentes no próprio texto.

Sendo assim, os sentidos dados a um mesmo texto dependem da época em que estão inseridos, pois no passado havia uma ideologia que se modificou. Também se deve levar em conta a história de leitura de cada pessoa.

Para Nilce Sant'Anna Martins (1989, p.26), uma figura referencial para os estudos estilísticos no Brasil, por meio da expressividade manifestam-se estados emotivos e julgamentos de valor, que despertam reações também de ordem afetiva no leitor de uma obra. É muito comum notar que, ao ler um poema, por exemplo, a pessoa identifica-se com a mensagem exposta. Para explicar tal fenômeno recorre-se aqui ao crítico Benedetto Croce, o qual acredita ser toda a expressão de um poeta representação dos sentimentos humanos:

\footnotetext{
${ }^{60}$ ECO, Sei passeggiate nei boschi narrativi - Trad. Hildegard Feist, 1994, p. 12
} 
"Em toda expressão de um poeta, em toda criatura de sua fantasia, está inteiro o destino humano, todas as esperanças, todas as ilusões, as dores e as alegrias, as grandezas e as misérias humanas, o drama inteiro do real, a devir e crescer perpetuamente sobre si mesmo, sofrendo e alegrando-se ${ }^{61}$."

Acredita-se que o discurso "aberto" de Leopardi, como se verá nas análises a seguir, não tem como objetivo consolar e agradar o leitor, mas colocar o homem diante de seus problemas, renovando a sua percepção bem como a sua maneira de compreender as coisas.

\subsection{Dificuldade e importância da tradução poética}

Conforme já explicado, a escolha estilística em um poema pode significar a chave de interpretação para o leitor. É pensando nisso que ao longo do tempo, tem-se discutido intensamente a respeito da dificuldade de traduzir textos literários. Críticos e poetas divergem em suas opiniões: enquanto uns defendem a impossibilidade, outros acreditam na possibilidade desse tipo de tradução.

Roman Jakobson, em seu ensaio Aspectos lingüísticos da tradução (1970, p.60), defende a possibilidade de toda a experiência cognitiva ser traduzível em qualquer língua existente. Todavia, podem ocorrer deficiências, mas nesses casos a terminologia poderá ser substituída por empréstimos, calços, neologismos, transferências semânticas e por circunlóquios. Portanto, independentemente do signo verbal e da forma como é feita a sua interpretação, a comunicação será sempre transponível.

Três são os tipos de tradução classificados pelo linguista: tradução intralingual ou reformulação, tradução inter-semiótica ou transmutação e tradução interlingual ou tradução propriamente dita. [grifo do autor]

$\mathrm{Na}$ tradução intralingual, tem-se a substituição dos signos linguísticos por outros signos da mesma língua. Por meio da interpretação, faz-se uso da sinonímia, da definição, da

\footnotetext{
${ }^{61}$ In: ECO, 2005, p. 69
} 
metalinguagem, da paráfrase, entre outros recursos, por exemplo, para superar as barreiras da compreensão, daí a reformulação explicada pelo autor.

Quando se realiza a substituição dos signos verbais por outros não verbais, cumpre-se a tradução que Jakobson denomina inter-semiótica. É o caso de uma representação pictórica, ou sonora, por exemplo, baseadas na interpretação de um texto escrito.

$\mathrm{Na}$ tradução interlingual ocorre a substituição dos signos linguísticos de uma língua por os de outra, sempre por meio da interpretação. Como o próprio autor especifica, trata-se da tradução propriamente dita.

Para Jakobson, essas substituições não poderão, porém, ter uma equivalência completa entre as unidades de código. Ou seja, não será possível manter a identidade absoluta de um signo linguístico em sua tradução, seja esta intralingual, inter-semiótica ou interlingual. A presença da palavra "interpretação", nas definições dos tipos de tradução dada por Jakobson, abre espaço à subjetividade do tradutor, o que abrange uma escolha nos eixos paradigmático e sintagmático, por exemplo. O que se almeja na tradução é manter a equivalência entre as mensagens. Daí a afirmação de Jakobson ao considerar o nível cognitivo da linguagem traduzível.

Todavia, a postura de Jakobson muda em relação à traduzibilidade dos gracejos, dos sonhos, da magia, definidos pelo mesmo como "mitologia verbal de todos os dias"62, e, sobretudo, da poesia.

Para ele:

Em poesia, as equações verbais são elevadas à categoria de princípio construtivo do texto. As categorias sintáticas e morfológicas, as raízes, os afixos, os fonemas e seus componentes (traços distintivos) - em suma, todos os constituintes do código verbal - são confrontados, justapostos, colocados em relação de contigüidade de acordo com o principio de similaridade e de contraste, e transmitem assim uma significação própria. (1970, p.72)

\footnotetext{
${ }^{62}$ JAKOBSON, 1970, p. 70.
} 
Sendo assim, a poesia, por definição, é considerada intraduzível. Para solucionar tal questão, o linguista sugere adotar uma transposição criativa, por meio da transposição intralingual, inter-semiótica ou interlingual, visando sempre à equivalência da mensagem.

E assim muitos outros teóricos, bem como poetas, são condizentes à ideia de que se pode conservar somente o sentido numa tradução poética, enquanto se perde a sua forma.

Pensando nessa dualidade, entre a tradutibilidade da forma/conteúdo de um poema, um importante nome deve ser citado: Walter Benjamin, o qual, em seu consagrado texto A tarefa do tradutor, demonstra a dualidade também existente entre o texto traduzido e o original.

Para Benjamin:

"A tradução é uma forma. Para compreendê-la como tal, é preciso retornar ao original. Pois nele reside a lei dessa forma, enquanto encerrada em sua traduzibilidade.” (2001, p. 191)

Assim, é possível dizer que para Benjamim, a tradução pode apresentar sinais do original, mas que é sempre ao texto original que se deve recorrer para uma compreensão desses sinais.

Muito bonita é a imagem da "ânfora quebrada", usada por Benjamin, representando o relacionamento entre a tradução de uma obra poética e o original. A ânfora simboliza o texto original, enquanto que o ato de traduzir vem representado pela ânfora em cacos a ser reconstituída. Em suas palavras, tem-se:

Assim como os cacos de um vaso, para poderem ser recompostos, devem seguir-se uns aos outros nos menores detalhes, mas sem se igualar, a tradução deve, ao invés de procurar assemelhar-se ao sentido do original, ir reconfigurando, em sua própria língua, amorosamente, chegando até aos mínimos detalhes, o modo de designar do original, fazendo assim com que ambos sejam reconhecidos como fragmentos de uma língua maior, como cacos são fragmentos de um vaso." (2001, p. 207)

Sendo assim, para Benjamin, a tradução não deveria procurar assemelhar-se ao sentido do original, mas recriar seus mínimos detalhes, visto que o sentido do original liga-se precisamente a cada palavra específica e ao modo como essas palavras são adotadas. Mas mesmo assim, o 
resultado lembrará a forma - a ânfora original - todavia, tratar-se-à de uma reconstituição. E é por meio dessa recriação que, em suma, o autor define qual é a tarefa do tradutor: resgatar a linguagem pura que está exilada na língua de origem.

Em um período em que afloram vários estudos sobre a tradução, não se poderia deixar aqui de abordar a contribuição italiana, mais precisamente, o pensamento leopardiano sobre o tema. Leopardi, além de ser um exímio tradutor de autores clássicos ${ }^{63}$, dedica também boa parte de sua reflexão sobre a teoria da tradução. Muitas são as páginas no Zibaldone em que é possível perceber o seu posicionamento - que será logo descrito - em relação ao assunto.

Em uma carta direcionada ao seu amigo Pietro Giordani, Leopardi escreve:

[...] e in oltre mi pare d'essermi accorto che il tradurre così per esercizio vada veramente fatto innanzi al comporre, e o bisogni o giovi assai per divenire insigne scrittore, ma che per divenire insigne traduttore convenga prima aver composto ed essere bravo scrittore, e che in somma una traduzione perfetta sia opera più tosto da vecchio che da giovane ${ }^{64}$. (29 Dicembre 1817)

Suas palavras explicam a importância de um escritor dedicar-se ao ato da tradução. Leopardi deixa claro que o ofício do tradutor está diretamente relacionado ao ofício do escritor, e vice-versa, pois é por meio da tradução que o escritor desenvolverá a arte do escrever bem.

Leopardi é um grande admirador da cultura clássica, por isso ele acredita ser a tradução dessas obras a mais oportuna para aperfeiçoar o escritor, já que este poderá extrair o ouro dos clássicos e aplicá-lo em seus escritos ${ }^{65}$. Dessa forma, o escritor aprenderá a tornar-se natural e simples no ato de compor, que são características típicas dos clássicos.

\footnotetext{
${ }^{63}$ Leopardi traduziu diversas obras clássicas, destacam-se aqui: o quinto idílio de Mosco, a Batracomiomaquia do pseudo-Homero, a Titanomaquia de Hesíodo, o segundo livro da Eneida de Virgílio e o primeiro livro da Odisséia de Homero, entre outras.

64، [...] e além disso me parece ter percebido que o traduzir por exercício deva realmente ser feito antes de compor, e ou precise ou favoreça muito o ofício de um exímio escritor, mas que para ser exímio tradutor convém antes ter composto e ser um bom escritor, e que em suma uma tradução perfeita seja obra mais de um escritor experiente do que de um iniciante". (29 de dezembro 18170) - [Trad. nossa]

65 “....vo leggendo i miei Classici, Greci la mattina, Latini dopo pranzo, Italiani la sera;...dopo il quale impratichitomi bene del Greco e arricchitomi dell'oro dei Classici, fo conto di uscire in campo con una solenne traduzione (tanto solenne quanto posso darla io) e poi lasciar fare alla inclinazione e alla fortuna. A Pietro Giordani - 5 Dicembre 1817 ( LEOPARDI. Epistolario, p.66) - http://cronologia.leonardo.it/leopardi/leop066.htm acessado em 21/12/09 às 16h). “...vou lendo os meus Clássicos, Gregos pela manhã, Latinos de tarde e Italianos à noite;...após o que, tendo
} 
Os clássicos são escolhidos como exemplo a seguir porque para o poeta eles estão mais próximos da natureza, diferentemente daquilo que ocorre na modernidade. Antonio Prete, em seu livro Finitudine e infinito: su Leopardi, aborda tal ideia:

"Per Leopardi non c'è ascolto, né imitazione, laddove la natura, per via dell' 'incivilimento' e della 'spiritualizzazione', è sotterrata: soltanto ricorrendo alla mediazione dei poeti antichi, i soli davvero prossimi alla vita della natura, è possibile conoscere e ascoltare la natura $^{66} \cdot "(1998$, p.164)

Como se percebe, a naturalidade e a simplicidade - características dos clássicos - são para Leopardi qualidades inseparáveis da arte do escrever bem. Mas se um tradutor tem como tarefa repetir o estilo e o dito de outrem, usando as próprias palavras, como poderá ele fazer isso sem afetação? Leopardi afirma que o traduzir é uma arte, principalmente em se tratando de alta literatura - em que uma das suas principais qualidades consiste em evitar a afetação, criando um estilo natural e espontâneo, indo, portanto, contra a natureza do tradutor, o qual, por sua vez, não pode ser espontâneo ${ }^{67}$.

Por mais que exista esse dualismo entre a naturalidade do escritor e a afetação do tradutor, Leopardi também acredita que o trabalho do tradutor equipara-se ao do escritor. Assim como o poeta, para encontrar a linguagem poética, deve "desenterrar" a natureza que fala nele mesmo ${ }^{68}, \mathrm{o}$ tradutor também deve desvelar aquilo que está escondido no texto original e encontrar a melhor maneira para transmitir a língua do poeta.

praticado bastante o grego e me enriquecido com o ouro dos Clássicos, penso em entrar em campo com uma tradução solene (não tão solene quanto se esperaria) e depois deixar que atuem o acaso e a fortuna. A Pietro Giordani, 5 de dezembro de 1817. (Trad. LUCCHESI, Prosa e poesia, p. 727).

66 "Para Leopardi não se escuta, nem se imita, lá onde a natureza, por causa da "incivilidade" e da "espiritualização", está subterrada: somente recorrendo à mediação dos poetas antigos, os únicos realmente próximos da natureza, é possível conhecer e escutar a natureza". - [Trad. nossa]

67 Zib.[319-20].

68 "Il poeta non imita la natura: ben è vero che la natura parla dentro di lui e per la sua bocca. [...] Così il poeta non è imitatore se non di se stesso." (Zib. 4372-73: 10 Sett. 1828)

"O poeta não imita a natureza: na verdade é a natureza que fala dentro dele e por meio de sua boca. [...] Então o poeta não é imitador se não dele mesmo.” (Zib. 4372-73: 10 de setembro de 1828) - [Trad. nossa] 
Fundamental é a comparação que Leopardi faz entre os efeitos que se têm ao ler um texto em língua estrangeira e os que se têm ao ver uma imagem reproduzida por uma câmera escura ${ }^{69}$. É possível encontrar tal relação no Zibaldone, [963]:

[...] l'effetto di una scrittura in lingua straniera sull'animo nostro, è come l'effetto delle prospettive ripetute e vedute nella camera oscura, le quali tanto possono essere distinte e corrispondere veramente agli oggetti e prospettive reali, quanto la camera oscura è adattata a renderle con esattezza; sicchè tutto l'effetto dipende dalla camera oscura piuttosto che dall'oggetto reale. (20-22 Aprile 1821)

Para Leopardi, cada pessoa pensa e sente na sua própria língua, ou naquela que lhe é mais familiar. Com isso, ao se deparar com um texto em língua estrangeira, o leitor só conseguirá "apreciar" as palavras, os gracejos, a elegância, as formas, o discurso entre outros elementos, se os relacionar com a sua língua familiar.

É então que entra em questão o princípio da câmera escura: quando o leitor observa uma frase em língua estrangeira, ele não faz uma transposição imediata, ele a projeta para dentro de si, numa espécie de câmera escura. Em seu universo linguístico, ele a vê como uma imagem invertida, que precisa ser decodificada. Dependendo do "sentimento lingüístico" do tradutor, ocorre, então, uma apropriação interior silenciosa e mágica ${ }^{70}$. É nesse ponto que Leopardi diz poder "sentir" e "apreciar" a língua e não "entender" e "conhecer", pois se está operando com o intelecto, o qual faz uso de outros meios ${ }^{71}$. Quanto mais o leitor se familiarizar com a própria

\footnotetext{
${ }^{69}$ Câmera escura é um tipo de aparelho óptico, desenvolvido no século XIX, mas o seu princípio já é estudado desde a Antiguidade. Quando se há um compartimento escuro, com um pequeno orifício em uma de suas paredes, é possível recriar num papel branco, situado no lado oposto desse orifício, uma imagem invertida captada do lado de fora, com suas formas e cores próprias. Dependendo do tempo de exposição à luz, a imagem pode ficar mais ou menos definida.

"O efeito de uma escrita em língua estrangeira na nossa alma, é como o efeito das perspectivas repetidas e vistas na câmera escura, as quais podem ser distintas e corresponder realmente aos objetos e perspectivas reais, conforme a câmera escura é adaptada a recriá-las com exatidão; logo todo o efeito depende mais da câmera escura do que do objeto real." (20-22 de abril de 1821) - [Trad. nossa]

${ }^{70}$ PRETE, 1998, p.145 - [Trad. nossa].

71 "Perchè l'uomo superficiale; l'uomo che non sa mettere la sua mente nello stato in cui era quella dell'autore; insomma l'uomo che appresso a poco non è capace di pensare colla stessa profondità dell'autore, intende materialmente quello che legge, ma non vede i rapporti che hanno quei detti col vero, non sente che la cosa sta così, non iscuoprendo il campo che l'autore scopriva, non conosce i rapporti e legami delle cose ch'egli vedeva [...]" (Zib. [348])

"Porque o homem superficial; o homem que não sabe colocar a sua mente no estado em que estava a do autor; em suma, o homem que, digamos, não é capaz de pensar com a mesma profundidade do autor, entende materialmente aquilo que lê, mas não vê as relações que têm aqueles dizeres com o real, não sente que a coisa está desta maneira,
} 
língua, e se abrir à experiência literária - no sentido de aprazer-se com os artifícios literários maior será a sua proximidade com a outra língua.

Assim, como é possível adaptar a câmera escura para se obter uma imagem mais definida, também o tradutor pode se "adaptar" para conseguir recriar, da melhor forma possível, o texto original. Um dos recursos a ser utilizado, por exemplo, é o saber escutar o texto, além de saber observar os particulares nele presentes, e é sob esse viés que se entende a expressão utilizada por Leopardi "renderle con esattezza” (recriar com exatidão).

Refletindo sobre a importância da "exatidão" para o poeta, Prete (1998, p.147) afirma:

Per Leopardi, per la sua poetica, il particolare, la percezione minima e ravvicinata, l' "esattezza" sono il mezzo per rappresentare il vago, l'indefinito, cioè la parvenza di infinito. Ossimori forti della poesia leopardiana: nel limite si dispiega la rappresentazione dell'infinito, o meglio l'esperienza di un'impossibile rappresentazione, di una rappresentazione che fa naufragio ${ }^{72}$.

Como se percebe, importantíssima é para Leopardi a atenção que se deve ter aos detalhes, pois eles contribuem muito para a formação da mensagem que se quer passar ao leitor.

Vários são os elementos que constituem a retórica poética, como o ritmo, a estrutura sintático-verbal, as rimas, as figuras de linguagem, a metrificação, entre outros. A todos esses detalhes técnicos, típicos do gênero literário, deve-se ater o tradutor, por isso Leopardi afirma que "[...] senza esser poeta non si può tradurre un vero poeta" ".

Um bom tradutor deve, portanto, observar minuciosamente o texto, mas sem se esquecer de observar também o estilo do autor. Conservar o estilo do autor na língua do tradutor é, como visto, uma tarefa árdua, mas esta é uma das tarefas do tradutor.

não descobrindo o campo que o autor descobria, não conhece as relações e conexões das coisas que ele via [...]" (Zib. [348]) - [Trad. nossa]

72 "Para Leopardi, para a sua poética, o particular, a percepção mínima e aproximada, a "exatidão" são o meio para representar o vago, o indefinido, ou seja, o vestígio do infinito. Oxímoros fortes da poesia leopardiana: no limite se desdobra a representação do infinito, ou melhor, a experiência de uma impossível representação, de uma representação que faz naufrágio.

73 "sem ser poeta não se pode traduzir um verdadeiro poeta" - [Trad. nossa] Prefácio da tradução do segundo livro da Eneida - disponível on-line: http://www.bibliotecaitaliana.it/repository/bibit/bibit001511/bibit001511.xml acesso em 24/03/2010. 
Conseguir manter as características de cada autor numa tradução, de modo que ele seja ao mesmo tempo estrangeiro e nacional, para Leopardi, é a ideia de uma tradução perfeita, conforme afirma numa passagem do Zibaldone de 19 de outubro de 1821. Como é possível perceber, grande é a contribuição à teoria da tradução da parte do poeta, pois há muito se discutia (e ainda se discute) sobre a dualidade entre a necessidade de se conservar aspectos linguísticos do texto ou o seu sentido numa tradução. Leopardi não vai contra um ou outro aspecto, ele acredita numa união entre as características do autor e do tradutor, sendo a língua italiana a mais apta para isso.

Refletindo ainda nas características de uma boa tradução, Leopardi diz no Zibaldone [2135-6]:

La perfezion della traduzione consiste in questo, che l'autore tradotto, non sia p.e. greco in italiano, greco o francese in tedesco, ma tale in italiano o in tedesco, quale egli è in greco o in francese. Questo è il difficile, questo è ciò che non in tutte le lingue è possibile. In francese è impossibile, [...] In tedesco è facile il tradurre in modo che l'autore sia greco, latino italiano francese in tedesco, ma non in modo ch'egli sia tale in tedesco qual è nella sua lingua. [...] Questa è la facoltà appunto della lingua italiana, e lo sarebbe stata della greca. Per questo io preferisco l'italiana a tutte e viventi in fatto di traduzioni. [...] Quello che dico degli autori dico degli stili, dei modi, dei linguaggi, dei costumi, della conversazione ${ }^{74}$. (21 Novembre 1821)

O ideal de uma boa tradução é, para Leopardi, conseguir traduzir um texto estrangeiro sem que o leitor encontre um efeito de estranhamento ao lê-lo, ou seja, sem que o autor traduzido permaneça sendo um grego, por exemplo, na língua italiana. Quando o tradutor "sente" e "aprecia" a língua estrangeira ele supera o efeito de "estrangeirismo" que essa outra língua produz, conseguindo assim realizar uma boa tradução. Desta forma, a língua estrangeira não perderá a sua característica própria ao ser traduzida e nem mesmo a própria língua perderá sua naturalidade em se tratando de uma tradução: é a síntese entre uma tradução "literal" e uma "adaptação".

A língua italiana, depois da grega, por ter uma longa tradição, é considerada por Leopardi a língua mais apropriada para se obter uma boa tradução; enquanto que discursa no Zibaldone,

\footnotetext{
74 "A perfeição da tradução consiste nisso, que o autor traduzido, não seja p.ex. grego em italiano, grego em francês em alemão, mas tal em italiano ou em alemão, qual ele é em grego ou em francês. Isso é o difícil, isso é o que nem em todas as línguas é possível. Em francês é impossível, [...] Em alemão é fácil o traduzir de modo que o autor seja grego, latino italiano francês em alemão, mas não que ele seja tal em alemão qual é na sua língua. [...] Essa é a capacidade da língua, e o teria sido da grega. Por isso eu prefiro a italiana a todas e vivas em relação a traduções. [...] Aquilo que digo dos autores digo dos estilos, dos modos, das linguagens, dos costumes, da conversação." (21 de novembro de 1821) - [Trad. nossa]
} 
em 20 de outubro de 1821, motivos para não considerar a língua francesa e alemã para tal função. Para ele, a língua francesa perdeu durante sua formação a sua liberdade, tornando-se inflexível a tudo que não lhe é próprio, enquanto que a alemã, por ser incompleta em sua formação, consegue transferir as palavras, mas não consegue recriar o espírito e a vida das palavras estrangeiras. Com isso, o poeta valoriza a própria língua por ter características favoráveis à tradução: flexibilidade, adaptação e liberdade.

Ao equiparar a figura do tradutor com a do autor, Leopardi demonstra a sua modernidade. Ideia que é defendida ainda hoje por alguns críticos da tradução como Octavio Paz, em seu livro Tradução literatura e literalidade (1971). No capítulo homônimo, Paz diz:

[...] a atividade do tradutor é paralela à do poeta, com esta diferença marcante: ao escrever, o poeta não sabe como será seu poema; ao traduzir, o tradutor sabe que seu poema deverá reproduzir o poema que tem diante dos olhos. Em seus dois momentos a tradução é uma operação paralela, ainda que em sentido inverso, à criação poética. $\mathrm{O}$ poema traduzido deverá reproduzir o poema original, que, como já dito, não é sua cópia e sim sua transmutação". (1971, p.12)

Não só o tradutor é colocado no mesmo nível do autor, como também a figura do tradutor é vista como necessária aos grandes letrados, por torná-los imortais diante das novas gerações. Assim explica Leopardi:

"[...] per traduzioni ai dotti e ai grandi letterati intendo, senza dir altro, quelle che gli scrittori loro fanno immortali, e per cui presso una nazione la fama e il nome del traduttore sono come annestati innestati? a quelli dell'autore ${ }^{75}$."

Como se percebe, a tradução pode vir a ser um importante recurso para propagar no tempo e no espaço a obra de um escritor. Recurso esse defendido pelo poeta e que por sua vez o beneficiou e continua beneficiando, já que inúmeras são as traduções feitas de suas obras, as quais contribuem para despertar o interesse do leitor pelos textos de Giacomo Leopardi.

\footnotetext{
75 “....] por traduções necessárias aos doutos e aos grandes literatos entendo, sem nada mais a dizer, aquelas que tornam seus escritores imortais, e pela qual em uma nação a fama e o nome do tradutor são como que anexados aos do autor." - [Trad. nossa] - Introdução à tradução da Titonomaquia de Hesiódo por Leopardi. Disponível on-line: http://www.bibliotecaitaliana.it/repository/bibit/bibit000995/bibit000995.xml - (acesso 29/03/2010)
} 
3.0 ANÁLISE INTERPRETATIVA DE POEMAS LEOPARDIANOS E DE SUAS TRADUÇÕES

\subsection{O CANTO SOLITÁRIO DE UM POETA}

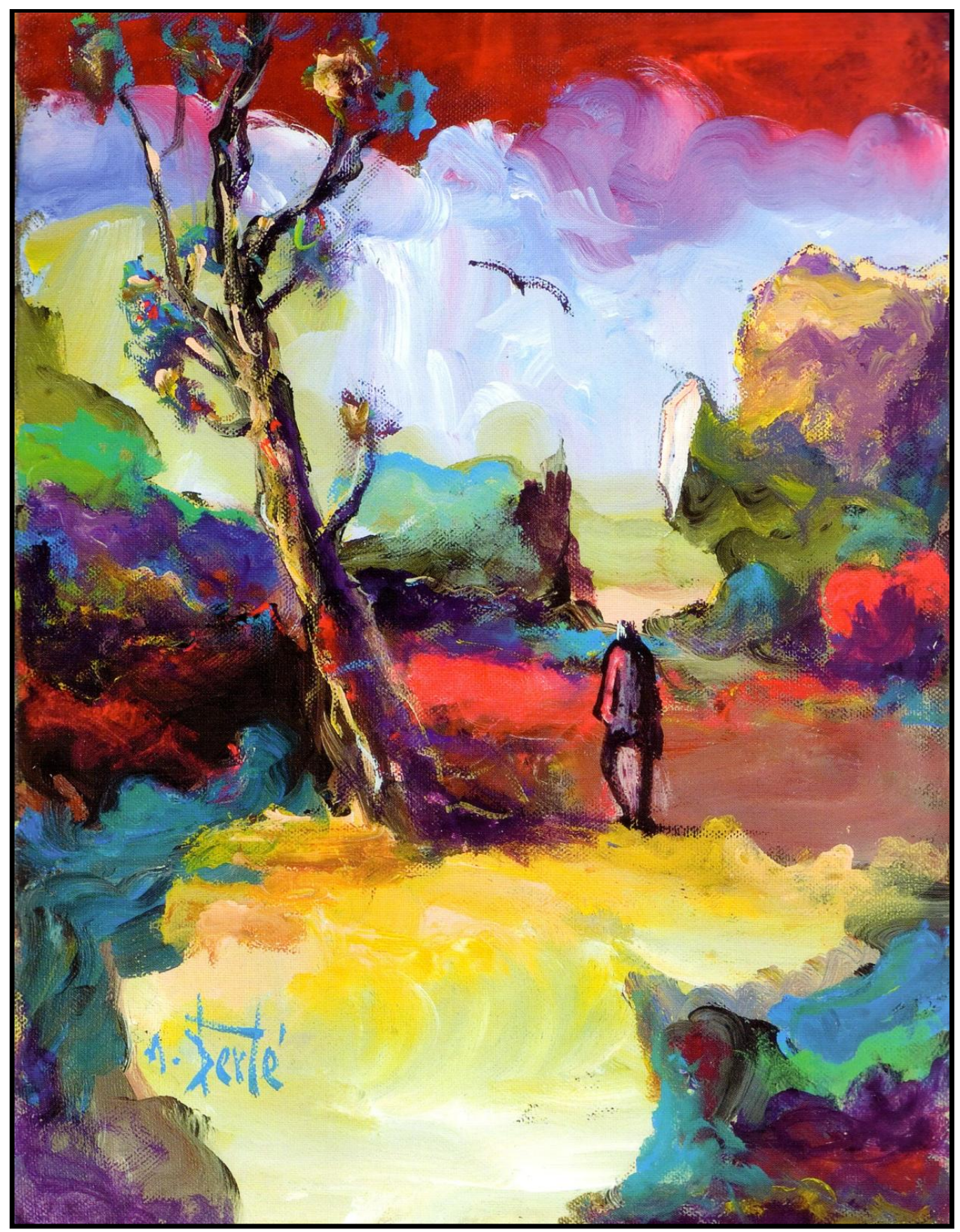

IL PASSERO SOLITARIO N² - Antonio Bertè 


\subsection{O CANTO SOLITÁRIO DE UM POETA: pessimismo individual}

O pensamento leopardiano desenvolve-se de forma não sistemática, exprimindo-se conforme sua vivência e experiência. Quatro são os momentos que serão aqui considerados: pessimismo individual; pessimismo histórico; pessimismo cósmico e pessimismo heroico; os quais não se sucedem de forma organizada, por mais que representem formas distintas de interpretar a condição humana.

A primeira fase que se apresentará nesse capítulo é a do "pessimismo individual", fase presente na temática do poema Il passero solitario que se analisará a seguir. Por mais que no poema escolhido o foco não seja na figura de um jovem que reflete sobre a sua própria condição, mas na de um adulto que medita sobre a solidão que sentirá na sua velhice, decidiu-se aqui identificar o poema escolhido à primeira fase do pessimismo leopardiano, apoiados nos dizeres do crítico Giulio Ferroni, por ele ser "como uma retomada e um olhar 'do amanhã' à matéria poética da juventude.” (2003, p.582) - [Trad. nossa]

Leopardi, aos poucos, desenvolve um "pessimismo individual" por diversos motivos, como por exemplo: por viver em um ambiente familiar rígido, privado de afeto; por angustiar-se com o ambiente recanatense; além de considerar a sorte adversa somente contra ele, o que o leva a viver em isolamento.

Por ter um caráter sensível, o jovem poeta sempre sentiu sede de afeto, que não conseguia saciar em seu ambiente familiar. Sua mãe, extremamente religiosa, não demonstrava carinho para com os filhos:

mancò all'infanzia dei giovani Leopardi, anime irrequiete e ardenti, la gioia ineffabile della tenerezza visibile e delle carezze della madre. La contessa Adelaide amava i suoi figli, ma da cristiana austera [...] essa spinse all'estremo la riserbatezza che regnava nelle antiche famiglie [...] tenendo per massima di non cedere a nessuna dimostrazione di tenerezza. Essa stendeva la sua mano alle labbra de' suoi figli, ma non se li strinse mai al seno ${ }^{76}$. (LEOPARDI, T., 2002, pp.138-139)

\footnotetext{
76 "faltou na infância dos jovens Leopardi, almas irrequietas e ardentes, a alegria inefável da ternura visível e dos carinhos da mãe. A condessa Adelaide amava os seus filhos, mas como cristã austera [...] ela levou ao extremo a
} 
Até mesmo com seu pai, Leopardi não teve uma relação fácil, principalmente nos anos de sua adolescência. Em uma carta endereçada ao pai, mas que nunca foi lida por ele, escrita na ocasião de sua falida tentativa de fuga de Recanati, em julho de 1819, Leopardi desabafa:

Per quanto Ella [conte Monaldo] possa aver cattiva opinione di quei pochi talenti che il cielo mi ha conceduti, Ella non potrà negar fede intieramente a quanti uomini stimabili e famosi mi hanno conosciuto ed hanno portato di me quel giudizio ch'Ella sa, e ch'io non debbo ripetere. [...] Io vedeva parecchie famiglie di questa medesima città, molto, anzi senza paragone meno agiate della nostra, e sapeva poi d'infinite altre straniere, che per qualche leggero barlume d'ingegno veduto in qualche giovane loro individuo, non esitavano a far gravissimi sacrifici affine di collocarlo in maniera atta a farlo profittare de' suoi talenti. Contuttochè si credesse da molti che il mio intelletto spargesse alquanto più che un barlume, Ella tuttavia mi giudicò indegno che un padre dovesse far sacrifizi per me, nè le parve che il bene della mia vita presente e futura valesse qualche alterazione al suo piano di famiglia. [...] Contuttociò Ella lasciava per tanti anni un uomo del mio carattere, o a consumarsi affatto in istudi micidiali o a seppellirsi nella più terribile noia, e per conseguenza, malinconia, derivata dalla necessaria solitudine e dalla vita affatto disoccupata, come massimamente negli ultimi mesi ${ }^{77}$.

Nem mesmo o ambiente social de Recanati o consola. Na passagem [273] do Zibaldone, ele revela como os seus conterrâneos o consideram:

Nella mia patria, dove sapevano ch'io era dedito agli studi, credevano ch'io possedessi tutte le lingue, e m'interrogavano indifferentemente sopra qualunque di esse. [...] E non perciò mi credevano una gran cosa, e per l'ignoranza non sapendo che cosa sia un letterato, non mi credevano paragonabile ai letterati forestieri, malgrado la detta opinione che avevano di me. [...] Ma s'io mostrava che le mie cognizioni fossero un

reserva que reinava nas antigas famílias [...] tendo como princípio não ceder a nenhuma demonstração de ternura. Ela estendia a sua mão aos lábios de seus filhos, mas não os aconchegou nunca ao seu peito". [Trad. nossa]

${ }^{77}$ http://docenti.lett.unisi.it/frontend/?rr=BD_49_10 (Acessado em 01/02/2010 às 20h)

"Por mais que o senhor possa ter uma má opinião sobre os poucos talentos que o Céu me concedeu, não poderá desabonar inteiramente tantos homens estimáveis e famosos que me conheceram e julgaram do modo que o senhor sabe - e que não devo repetir. [...] Eu via inúmeras famílias desta mesma cidade, muito, incomparavelmente menos abastadas que a nossa, e sabia de infinitas outras estrangeiras que, ao menor lampejo de engenho notado em um dos seus jovens, não hesitavam em fazer duros sacrifícios a fim de capacitá-lo a aproveitar os seus talentos. Apesar de muitos acreditarem que o meu intelecto irradiasse um pouco mais do que um simples lampejo, o senhor no entanto julgou-me indigno de qualquer sacrifício paterno, o bem da minha vida presente e futura não the pareceu digno de qualquer alteração no seu planejamento doméstico. [...] Contudo, o senhor deixava por anos e anos um homem do meu caráter consumindo-se em estudos mortíferos ou enterrando-se no mais profundo tédio e, por conseguinte, na melancolia, derivada da necessária solidão e da vida de fato ociosa, mormente nos últimos meses". [Trad. LUCCHESI; 1996, pp. 753-754] 
poco minori ch'essi non credevano, la loro stima scemava ancora, e non poco, e finalmente io passava per uno del loro grado ${ }^{78}$. (14 Ottobre 1820)

Em um ambiente familiar e social como esse, Leopardi vive cada vez mais em solidão idealizada, já que lhe faltava quem o compreendesse, consumindo seriamente sua saúde em meio a livros na biblioteca paterna.

Conforme se lê em uma carta enviada ao amigo Pietro Giordani, datada 26 de outubro de 1821, Leopardi, aos poucos, considera-se "escluso dalla gioia di vivere",79, alegria a qual todos fruem:

"Dopo tre soli anni, appena mi riconosceresti. Non più giovane, non più renitente alla fortuna: escluso dalla speranza e dal timore, escluso da'menomi e fuggitivi piaceri che tutti godono $[\ldots]{ }^{80,}$

Também no Zibaldone [143], Leopardi defendeu essa ideia:

"Sono stato sempre sventurato, ma le mie sventure d'allora erano piene di vita, e mi disperavano perchè mi pareva (...) che m'impedissero la felicità, della quale gli altri credea che godessero."

Dessa forma, o poeta acredita que a sorte tenha sido adversa somente com ele, condenando-o à solidão, já que se via incapaz de viver como os demais, rodeados de alegrias e afetos. E é esse estado de ânimo que se reflete no poema Il passero solitario.

\footnotetext{
78 "Na minha pátria, onde sabiam que eu era dado aos estudos, acreditavam que eu soubesse todas as línguas, e me perguntavam indiferentemente sobre qualquer delas. [...] E não por isso me consideravam grande coisa, e por ignorância não sabendo o que fosse um literato, não me consideravam comparável aos literatos estrangeiros, malgrado a tal opinião que tinham sobre mim. [...] Mas se eu mostrava que as minhas condições fossem um pouco menores das que eles acreditavam, a estima deles diminuía mais, e não pouco, e finalmente eu passava por um do grau deles. (14 de Outubro de 1820) - [Trad. nossa]

${ }^{79}$ PASSIGATO, G.; ZOIA, R., "La letteratura italiana per la maturità. '800- '900”, Clio, 2aed., 1993, p.128.

"Excluído da alegria de viver" [Trad. nossa]

${ }^{80} \mathrm{http}: / /$ cronologia.leonardo.it/leopardi/centouno/leop176.htm (acesso em 1/02/2010 às 18h).

"Passados três anos, mal me reconhecerias. Nem jovem, nem arredio à sorte: excluído da esperança e do temor, excluído dos mínimos e breves prazeres que todos desfrutam (...)”. [LUCCHESI; 1996, p.783)
} 


\subsubsection{IL PASSERO SOLITARIO de Leopardi no Brasil}

\section{"Il passero solitario"}

D'in su la vetta della torre antica, Passero solitario, alla campagna

Cantando vai finchè non more il giorno; Ed erra l'armonia per questa valle. 05Primavera dintorno

Brilla nell'aria, e per li campi esulta, Si ch'amirarla intenerisce il core.

Odi greggi belar, muggire armenti;

Gli altri augelli contenti, a gara insieme

10Per lo libero ciel fan mille giri,

Pur festeggiando il lor tempo migliore:

$\mathrm{Tu}$ pensoso in disparte il tutto miri;

Non compagni, non voli,

Non ti cal d'allegria, schivi gli spassi;

15Canti, e così trapassi

Dell'anno e di tua vita il più bel fiore.

Oimè, quanto somiglia

Al tuo costume il mio! Sollazzo e riso,

Della novella età dolce famiglia,

20 E te german di giovinezza, amore, sospiro acerbo de' provetti giorni,

Non curo, io non so come; anzi da loro

Quasi fuggo lontano;

Quasi romito, e strano

25Al mio loco natio,

Passo del viver mio la primavera.

Questo giorno ch'ormai cede alla sera,

Festeggiar si costuma al nostro borgo.

Odi per lo sereno un suon di squilla,

30Odi spesso un tonar di ferree canne,

Che rimbomba lontan di villa in villa.

Tutta vestita a festa

La gioventù del loco

Lascia le case, e per le vie si spande;

$35 \mathrm{E}$ mira ed è mirata, e in cor s'allegra.

Io solitario in questa

Rimota parte alla campagna uscendo,

Ogni diletto e gioco

Indugio in altro tempo: e intanto il guardo

40Steso nell'aria aprica
“O pardal solitário"

Do vértice que aguça a torre antiga, Solitário pardal, rumo à campina

Cantando vai enquanto a luz perdura;

E flutua a harmonia pelo vale.

A primavera em torno

Cintila no ar, e pelos campos vibra,

Tocando o coração de quem a mira.

Ovelhas balem, muge o gado em júbilo;

Brincam em bandos pássaros festivos

Que traçam espirais no céu aberto,

Saudando o tempo que se regozija.

$\mathrm{Tu}$, pensativo e alheio, tudo espias;

Sem parceiros, sem voos [acréscimo nosso]

Não te animas, e ao riso te recusas;

Cantas, e é assim que cruzas

Do ano e da vida a mais bela das flores.

Ai, como se assemelha

O teu costume ao meu! Folgança e riso

Da tenra idade idílica família,

E a ti, amor, irmão da juventude,

Suspiro amargo dos maduros dias,

Não busco, não sei como; ao invés, dele

Quase me esquivo e acanho;

Quase eremita, e estranho

Ao meu torrão natal,

Passo de minha vida a primavera.

É costume brindar em nossa aldeia

A esse dia que aos poucos anoitece.

Ouve no céu sereno o som de um sino,

Ouve o espocar dos tiros de um fusil,

Que ribomba acolá, de vila em vila.

Vestidos para a festa,

Os jovens do lugar

Saem de casa e espalham-se na rua;

Olham-se e são olhados, e sorriem.

Recém-chegado e só

A essa remota parte da campina,

Cada deleite e jogo

Adio sempre; e todavia o olhar,

Distenso no ar radiante, 
Mi fere il Sol che tra lontani monti, Dopo il giorno sereno, Cadendo si dilegua, e par che dica Che la beata gioventù vien meno.

45Tu, solingo augellin, venuto a sera

Del viver che daranno a te le stelle, Certo del tuo costume

Non ti dorrai; che di natura è frutto Ogni vostra vaghezza.

50A me, se di vecchiezza

La detestata soglia

Evitar non impetro,

Quando muti questi occhi all'altrui core, E lor fia vóto il mondo, e il dì futuro

55Del dì presente più noioso e tetro,

Che parrà di tal voglia?

Che di quest'anni miei? che di me stesso?

Ahi pentirommi, e spesso,

Ma sconsolato, volgerommi indietro.

[Giacomo Leopardi]
Fere-me o sol que ao longe, entre as montanhas, Depois que o dia aquece,

Caindo some, e diz-me, agonizante,

Que a casta juventude desfalece.

A ti, ave sozinha, quando à noite

Da vida te levarem as estrelas,

Lembrar o teu costume

Não doerá, pois da natureza é fruto

Teu apetite antigo.

A mim, se não consigo

Da velhice evitar

O tão doloroso umbral,

Quando este olhar emudecer às almas,

E lhe for erma a terra, e o seu futuro

Do que o presente mais tedioso e horrendo, Que direi desse afã?

E destes anos meus? O que de mim?

Terei remorso, enfim,

$\mathrm{E}$, triste, irei então retrocedendo.

[Tradução de Ivan Junqueira]

81

O poema Il passero solitario, de datação incerta, foi publicado pela primeira vez na edição dos Canti em 1835, sendo colocado antes do idílio L'Infinito, composto em 1819. Todavia, por ter uma estrutura características dos poemas compostos por Leopardi entre 1828-1830, e por não ter sido publicado anteriormente, acredita-se que tal poema tenha sido escrito entre os anos de 1831 a 1834.

Do ponto de vista formal, o poema é composto de três estrofes de tamanhos diferentes [16 versos, 28 versos e 15 versos], num total de 59 versos.

Numa contagem de sílabas métricas, seguindo o método da língua portuguesa, seus versos são hexassílabos e decassílabos livremente distribuídos, ora apresentando um ritmo

\footnotetext{
${ }^{81}$ No livro "Giacomo Leopardi: Poesia e Prosa", org. por Marco Lucchesi, editado pela Nova Aguilar em 1996, não consta o $13^{\circ}$ verso traduzido por Ivan Junqueira. Conforme esclarecido pelo organizador em troca de e-mail (31/01/2010), trata-se de um erro que passou e que será solucionado na segunda edição da obra. No entanto, contatou-se também por e-mail, em 24/03/2010, o poeta Ivan Junqueira, o qual afirma ter perdido o original do poema, mas que sugere a seguinte forma de tradução do verso 13: "Sem parceiros, sem voos", preferindo parceiros a companheiros ou camaradas.
} 
acelerado, ora lento, conforme as exigências descritivas. Seguindo o método da língua italiana, ter-se-á versos de sete e onze sílabas poéticas, visto que a contagem italiana de sílabas métricas vai até a última sílaba do verso em questão, enquanto em português finaliza na penúltima sílaba.

\section{Contagem de sílabas métricas no Brasil:}

D'in / su / la / ve / tta / de / lla / to / rre an / ti / ca,

$\begin{array}{llllllllll}1 & 2 & 3 & 4 & 5 & 6 & 7 & 8 & 9 & 10\end{array}$

Pri / ma / ve / ra / din / tor / no

$\begin{array}{llllll}1 & 2 & 3 & 4 & 5 & 6\end{array}$

Contagem de sílabas métricas na Itália:

D'in / su / la / ve / tta / de / lla / to / rre an / ti / ca,

$\begin{array}{lllllllllll}1 & 2 & 3 & 4 & 5 & 6 & 7 & 8 & 9 & 10 & 11\end{array}$

Pri / ma / ve / ra / din / tor / no

$\begin{array}{lllllll}1 & 2 & 3 & 4 & 5 & 6 & 7\end{array}$

O poema apresenta um esquema livre do ritmo: em certos momentos os hexassílabos apresentam o esquema 6 (3-6), em outros 6 (2-4-6). Enquanto os versos decassílabos marcam o acento conforme o esquema 10 (6-10) e 10 (4-8-10).

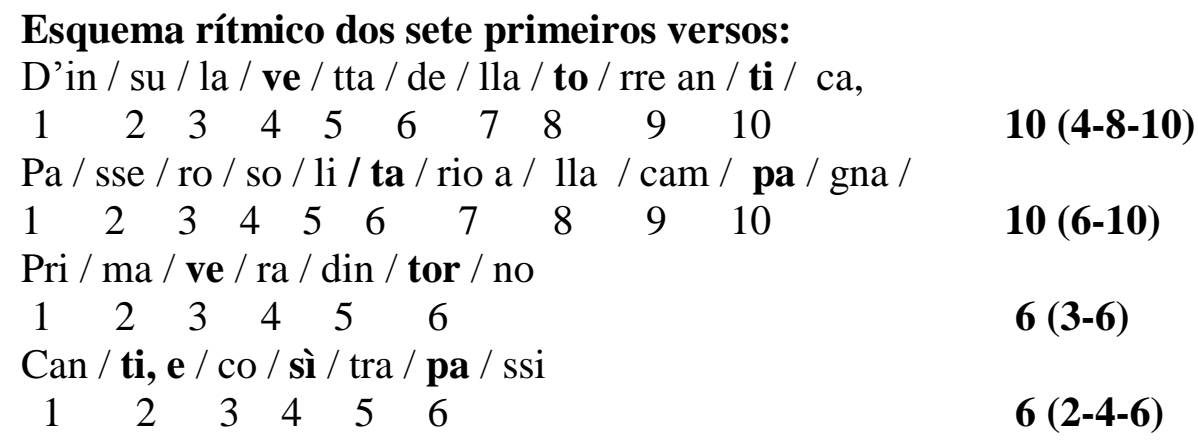

Quanto ao esquema rímico, o poema apresenta um jogo livre de repetições sonoras alternadas e no meio dos versos.

Esquema das rimas consoantes dos dezesseis primeiros versos.

\begin{tabular}{|l|l|c|l|}
\hline 1 D'in su la vetta della torre antica, & A & Gli altri augelli contenti, a gara insieme & G-H \\
\hline Passero solitario, alla campagna & B & 10Per lo libero ciel fan mille giri, & I \\
\hline Cantando vai finchè non more il giorno; & C & Pur festeggiando il lor tempo migliore: & F \\
\hline Ed erra l'armonia per questa valle. & D & Tu pensoso in disparte il tutto miri; & I \\
\hline 5Primavera dintorno & C & Non compagni, non voli, & K \\
\hline Brilla nell'aria, e per li campi esulta, & E & Non ti cal d'allegria, schivi gli spassi; & L \\
\hline Si ch'a mirarla intenerisce il core. & F & 15Canti, e così trapassi & L \\
\hline Odi greggi belar, muggire armenti; & G & Dell'anno e di tua vita il più bel fiore. & F \\
\hline
\end{tabular}


Por mais que as rimas pareçam escassas ao longo do poema, pode-se perceber como elas têm uma função unificadora entre os períodos. Nessa primeira parte do poema, o penúltimo verso do primeiro período rima com o primeiro verso do segundo período. $\mathrm{O}$ último verso do segundo período rima com os últimos versos do terceiro e do quarto períodos. Bem como o penúltimo verso do terceiro período com o primeiro do quarto período.

Como visto acima, todos os elementos presentes em um poema são importantes para a construção de sentido do mesmo. Até mesmo duas coisas aparentemente não relacionadas podem apresentar analogias.

Samuel Levin, em Estruturas Lingüísticas em Poesia (1975), distingue elementos de uma linguagem comum da poética, graças a um procedimento linguístico de acoplamento. No acoplamento, unem-se duas palavras aparentemente não relacionadas. Por um mecanismo linguístico, consegue-se aproximá-las seja por meio da fonética, da sintaxe ou da relação de sentido. Tais acoplamentos vêm classificados em Tipo I: ou de posição, relacionando termos posicionados da mesma forma; e em Tipo II: de natureza, relacionando termos no campo semântico ou fônico.

No poema de Leopardi, apresentam-se acoplamentos relacionados ou pelo sentido, ou pelo som. Sendo assim, nota-se o seguinte acoplamento no primeiro período:

- As palavras "aria" e "mirarla", presentes nos versos 6 e 7, formam uma rima toante. Ambas estão relacionadas com a "Primavera", a qual espalha luminosidade e frescor no ar, quase indicando uma nova vida para todos.

O poema "Il passero solitario" apresenta uma narrativa simulada. O eu-lírico fundese num papel de narrador em primeira pessoa e também de observador da vida ${ }^{82}$.

\footnotetext{
${ }^{82}$ Fundamental é esclarecer que ao longo das análises poder-se-á referir ao eu-lírico como "poeta", mas tal denominação é um simulacro, não se referindo ao autor do texto: Giacomo Leopardi, mas ao eu-poético, sob a forma de uma personagem: um poeta.
} 
As três estrofes do poema apresentam uma construção simétrica: a primeira estrofe é dedicada à vida do pássaro perante a natureza; o centro da segunda é o poeta e seu comportamento diante da sociedade; já na terceira estrofe, tem-se o confronto direto entre o modo de vida do pássaro e o do poeta, mas não feito de concordâncias entre os dois estilos de vida, e sim de contrastes.

A composição poética fundamenta-se em um paralelismo entre duas condições: o $\operatorname{pardal}^{83}$ é uma ave que segue sua vida, inserido em um ambiente natural, rodeado por outras aves, mas que prefere passar seus melhores dias - a primavera de sua vida - em isolamento; o poeta é um jovem que prefere viver em direção contrária à dos demais jovens, seus coetâneos. Ele prefere ver e sentir, em distância, a alegria e a despreocupação típica de sua idade. Aquilo que aproxima o pardal ao poeta é que por mais que exista uma distância entre seus dois mundos - animal e humano - ambos têm comportamentos similares: o isolamento perante a alegria comum que reina na cidade.

$\mathrm{Na}$ última parte do canto, tem-se uma oposição: enquanto o pássaro age naturalmente, sem se arrepender no futuro por não ter aproveitado sua juventude como os demais pássaros; o poeta lamentará não ter vivido de modo feliz o seu tempo melhor, volvendo-se sem nenhum conforto ao seu passado.

\section{Primeira estrofe: o pássaro}

Visto que o poema não está estruturado em estrofes regulares, a análise será feita seguindo uma divisão sintática por períodos. Na primeira estrofe, em cada período, tem-se fixado um momento: a apresentação do pássaro; a primavera em festa; os animais; e o pássaro relacionado com o mundo ao seu redor.

\footnotetext{
${ }^{83} \mathrm{O}$ pardal-doméstico, também conhecido como pardal-de-telhado, é uma espécie de ave muito comum no mundo inteiro. Quando em companhia, o pardal vive muitos anos com grande vivacidade, mas se solitário, seu tempo de vida diminui, talvez por esse motivo Ivan Junqueira escolheu intitular o poema, especificando o tipo de pássaro. A expressão "pardal solitário" também pode ser encontrada numa passagem do salmo 102,7 da Bíblia: "Não durmo, e sou como o pardal solitário no telhado."
} 
No primeiro período tem-se a apresentação da primeira personagem: o "passero"

D'in su la vetta della torre antica, Passero solitario, alla campagna Cantando vai finchè non more il giorno; Ed erra l'armonia per questa valle.
Do vértice que aguça a torre antiga, Solitário pardal, rumo à campina Cantando vai enquanto a luz perdura; E flutua a harmonia pelo vale.

Do alto de um velho sino, pertencente à igreja de S. Agostino em Recanati ${ }^{84}$, o solitário pardal, por instinto, segue cantado pela campina, divulgando assim uma bela harmonia pelo vale.

Nota-se que, já no primeiro verso, ao aproximar termos (como as preposições D'in $s u$, seguidas de palavras relacionadas à altura, vetta - torre) o poema ganha uma musicalidade crescente que é mantida na tradução em português, graças às palavras: vértice - aguça - torre, as quais levam o leitor a atingir cada vez mais uma altura imaginativa.

Outro fator importante desse primeiro período é a presença da assonância em /a/, pois tal volgal sugere a ideia de imensidão. Pode-se perceber que, além da altura atingida no verso inicial, o leitor poderá alargar sua visão, expandindo a cena pela campina.

Por mais que o pássaro esteja solitário, seu canto não aparenta ser lamuriante, ao contrário, parece ser uma exaltação à luz, já que perdurará enquanto não morrer o dia, expandindo uma bela harmonia por onde se estende. Bonita é a escolha da palavra erra para transmitir essa ideia de expansão, tão bem traduzida por flutua, na tradução em português, passando uma ideia de leveza do canto.

O segundo período introduz a primavera e o sentimento que ela traz nos corações:

\footnotetext{
${ }^{84}$ Por mais que a crítica costume identificar a torre descrita no poema como sendo a torre da igreja de Santo Agostino, também conhecida como "La torre del passero solitario", Leopardi no Zibaldone [4418] afirma que para o homem sensível e imaginoso, que vive, como ele mesmo [Leopardi] viveu, sentindo continuamente e imaginando, o mundo e os objetos são de uma certa forma duplos. Enquanto esse homem verá com seus olhos uma torre, uma campina; escutará com seus ouvidos um som de um sino, no mesmo tempo, com a imaginação verá uma outra torre, uma outra campina, escutará um outro som.

Pode-se dizer então que a torre nomeada no poema, bem como os lugares identificados pela crítica nos poemas de Leopardi como pertencentes a Recanati, ganham um "ar" universal, sendo também símbolo de algo maior, pertencente à imaginação.
} 
05Primavera dintorno

Brilla nell'aria, e per li campi esulta,

Si ch'amirarla intenerisce il core.
A primavera em torno

Cintila no ar, e pelos campos vibra,

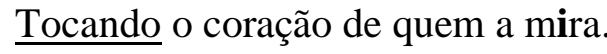

A harmonia do canto apresentada anteriormente se estende pela natureza, visto que é tempo de primavera. Tudo é luminoso, alegre e sereno. A assonância em /i/ reforça a ideia da solaridade que invade os versos. Na tradução em português para compensar a maior presença da vogal $i$ no poema original, escolheram-se palavras que ampliassem tal efeito, como por exemplo "vibra”, fazendo o sentimento passar pelo ar, ecoar pelos campos até tocar o coração de quem as está admirando.

O período inicia-se com um substantivo privado de artigo, o que sugere a ideia de personificação da primavera, tornando-a uma criatura que espalha luminosidade e alegria por onde passa. Essa personificação não foi mantida na tradução de Ivan Junqueira, visto que o período inicia com o artigo. Para compensar tal efeito, poder-se-ia marcar o substantivo pela inicial maiúscula, personificando assim a primavera.

Já no terceiro período tem-se a descrição do comportamento dos animais perante a primavera:

Odi greggi belar, muggire armenti;

Gli altri augelli contenti, a gara insieme 10Per lo libero ciel fan mille giri,

Pur festeggiando il lor tempo migliore:
Ovelhas balem, muge o gado em júbilo; Brincam em bandos pássaros festivos Que traçam espirais no céu aberto, Saudando o tempo que se regozija.

Os animais estão em festa: as ovelhas, o gado e os pássaros. Por terra ou por ar, festeja-se a vinda da primavera. O adjetivo “contenti", por mais que esteja relacionado com os pássaros, forma uma rima ao meio com o substantivo "armenti" do verso anterior; tal recurso cria um efeito que amplia o estado de alegria entre os animais.

Muito importante é a presença do pronome "altri" ao introduzir os pássaros que juntos voam contentes no céu, pois já sugere que um pássaro não participa dessa festa. 
Já na versão traduzida, a rima ao meio não foi mantida, sendo descrito o estado de júbilo do gado e a festividade dos pássaros que em bando brincam, sem sugerir a presença de um pássaro apartado.

No quarto período, o pássaro, apartado dos demais, ressurge:

Tu pensoso in disparte il tutto miri;

Non compagni, non voli,

Non ti cal d'allegria, schivi gli spassi; 15Canti, e così trapassi

Dell'anno e di tua vita il più bel fiore.
Tu, pensativo e alheio, tudo espias;

Sem parceiros, sem voos

Não te animas, e ao riso te recusas;

Cantas, e é assim que cruzas

Do ano e da vida a mais bela das flores.

O terceiro período não termina com um ponto, mas com um dois-pontos, marcando uma pausa forte, bem como o ritmo faz-se mais lento, já que o eu-lírico volveu sua atenção ao pássaro solitário. O primeiro verso desse último período começa com um pronome pessoal: "Tu", atraindo a atenção do leitor não mais à paisagem e ao comportamento do mundo circunstante, mas ao pássaro solitário.

Alheio ao comportamento dos outros animais, o pássaro observa seus símiles. Ele não procura companhia, não brinca no ar como os demais, nem se anima, e evita até mesmo a diversão. O pardal somente espia as outras aves, como indica a rima dos versos 10 e 12 (giri-miri), cantando, sua única satisfação. Esse canto é, porém, diferente do dos outros animais: é um canto que ressoa apartado. É dessa forma que o pássaro passa sua juventude: a mais bela flor de sua vida e da primavera. A rima dos versos 14 e 15 (spassi-trapassi) marca esse destaque entre o modo de viver a vida do pássaro solitário.

$\mathrm{Na}$ tradução de Ivan Junqueira, o jogo visto entre as rimas dos versos 10-12 e 14-15 foi bem mantido em forma de acoplamento. Nos versos 10 e 12, sente-se o eco entre as palavras "espirais" e "espias"; já no versos 14 e 15, tem-se um acostamento sonoro entre as palavras: "recusas" e "cruzas", compensando as rimas presentes na versão original. 


\section{Segunda estrofe: o poeta}

$\mathrm{Na}$ segunda estrofe, completando o paralelismo entre as personagens, tem-se a apresentação do poeta. Cinco são os períodos que compõem a estrofe, apresentando os seguintes temas: o poeta, a primavera em festa, o som, os jovens, o poeta e seu isolamento.

O primeiro período inicia-se com uma comparação explícita entre as personagens: pássaro e poeta.

Oimè, quanto somiglia

Al tuo costume il mio! Sollazzo e riso, Della novella età dolce famiglia, $20 \mathrm{E}$ te german di giovinezza, amore, sospiro acerbo de' provetti giorni, Non curo, io non so come; anzi da loro Quasi fuggo lontano; Quasi romito, e strano 25Al mio loco natio, Passo del viver mio la primavera.
Ai, como se assemelha O teu costume ao meu! Folgança e riso Da tenra idade idílica família, E a ti, amor, irmão da juventude, Suspiro amargo dos maduros dias, Não busco, não sei como; ao invés, dele Quase me esquivo e acanho; Quase eremita, e estranho Ao meu torrão natal, Passo de minha vida a primavera.

A estrutura sintática desse período é bastante curiosa: uma longa sequência de complementos, ricos em adjetivos e especificações, é regida por um único verbo - Non curo localizado no verso 22. Dessa forma, o poeta coloca em destaque vários aspectos positivos da vida, como por exemplo: a diversão; as risadas; o amor (visto também no seu sentido lato de inclinação ou apego profundo a algum valor ou a alguma coisa que proporcione prazer; entusiasmo $^{85}$, tal como o aprazeirar-se com a beleza da natureza) que caminha junto com a juventude. Todavia, esse mesmo amor atenua-se quando chegar a velhice, podendo somente ser dolorosamente suspirado.

Por todos esses prazeres naturais da juventude o poeta não se interessa, mas nem mesmo sabe explicar o porquê de seu comportamento, simplesmente ele se afasta. A rima toante nos versos 22 e 23 (non curo-fugo) acentuam o desejo de não compartilhar os prazeres juvenis, afastando-se de tudo e de todos, como indica também a rima (lontano-strano) dos versos 23 e 24.

\footnotetext{
${ }^{85}$ Dicionário Aurélio Eletrônico - Século XXI - Versão 3.0 - Novembro de 1999.
} 
$\mathrm{Na}$ tradução de Ivan Junqueira a estrutura sintática foi mantida, sendo os complementos (folgança, riso e amor) pré-postos ao verbo (Não busco). Contudo, no fim do verso 22, a expressão "da loro", consta substituída por "dele", o que mudaria a interpretação sugerindo que o poeta esquiva-se somete do amor e não dos demais prazeres, como demonstrado anteriormente ${ }^{86}$.

Nos três períodos seguintes, a atenção do poeta volta-se ao burgo em festa.

Questo giorno ch'ormai cede alla sera, Festeggiar si costuma al nostro borgo. Odi per lo sereno un suon di squilla, 30Odi spesso un tonar di ferree canne, Che rimbomba lontan di villa in villa.

Tutta vestita a festa

La gioventù del loco

Lascia le case, e per le vie si spande; $35 \mathrm{E}$ mira ed è mirata, e in cor s'allegra.
É costume brindar em nossa aldeia

A esse dia que aos poucos anoitece. Ouve no céu sereno o som de um sino, Ouve o espocar dos tiros de um fuzil [corr. nossa], Que ribomba acolá, de vila em vila.

Vestidos para a festa, Os jovens do lugar

Saem de casa e espalham-se na rua; Olham-se e são olhados, e sorriem.

Assim como descrito na primeira estrofe (o momento de festa na natureza e a alegria dos animais), em perfeito paralelismo, o eu-lírico descreve agora um momento de festa em seu burgo e a alegria de seus coetâneos.

Grande atenção é dada ao som que ecoa na vila. O poeta inicia a descrição com a atenção dirigida para o alto - no céu - onde ecoa o som do sino; aos poucos vai descendo o seu olhar, descrevendo o toar dos tiros em sinal de festa; para, enfim, mais abaixo, observar os jovens alegres, cheios daquele amor já descrito anteriormente - que juntos participam de uma festa.

Leopardi, na passagem [4293] do Zibaldone, explica o porquê lhe é caro o ecoar do som:

Una voce o un suono lontano, o decrescente e allontanante appoco appoco, o eccheggiante con un'apparenza di vastità ec. ec. è piacevole per il vago dell'idea ec. Però è piacevole il tuono, un colpo di cannone, e simili, udito in piena campagna, in una gran valle ec. il canto degli agricoltori, degli uccelli, il muggito de' buoi ec. nelle medesime circostanze ${ }^{87}$. (21 Settembre 1827)

\footnotetext{
${ }^{86}$ Consta na edição de referência a tradução da expressão "da loro" por "dele", todavia, conforme afirma o organizador da obra, Marco Lucchesi, trata-se de uma falha involuntária de transcrição, (mas não especifica a correção); tal erro espera pela segunda revisão. Acredita-se então que, provavelmente, a expressão "da loro" será substituída por “deles”, caso contrário a interpretação da mensagem mudaria, conforme demonstrado na análise.

87 "Uma voz ou um som longe, ou decrescente e afastante pouco a pouco, o ecoante com uma aparência de vastidão etc. etc. é prazeroso pelo vago da ideia etc. Mas é prazeroso o trovão, um golpe de canhão, e símiles, ouvidos em
} 
Para descrever tal quadro, faz-se uso de recursos expressivos, como é o caso das aliterações presentes nos versos 29, 30 e 31. No verso 29, tem-se a reprodução do som emitido pelos sinos, graças a repetição do som /s/. No verso 30, com a aliteração em /r/ cria-se um efeito do rumor surdo dos golpes de fuzil. Já no verso 31, a sucessão das nasais juntamente com a assonância em /a/ sugere a ideia do expandir do som emitido pelos fuzis, que se propaga pelo burgo.

Recursos expressivos também constam na tradução em português. Interessante é escolha na tradução do verbo "tonar" para "espocar", pois a combinação das oclusivas /p/ e /k/ com as vogais /o/ e /a/ reproduzem o som do estouro, assim como a aliteração em /r/, conforme explicado anteriormente. Já a repetição da nasalização presente no original não foi mantida na tradução em português, todavia ao escolher a palavra "acolá" o efeito de expansão do eco foi mantido, visto que "acolâ" é uma palavra oxítona que dá a ideia de avanço, além de ter o eco da sílaba "la" na palavra "vila" repetida duas vezes no verso.

No último período da segunda estrofe a alegria, então descrita, contrapõe-se à melancolia e à solidão do poeta; passando de um plano superficial (descrição da festa e da alegria entre os jovens) para um plano profundo (a solidão do poeta).

Io solitario in questa

Rimota parte alla campagna uscendo,

Ogni diletto e gioco

Indugio in altro tempo: e intanto il guardo

40Steso nell'aria aprica

Mi fere il Sol che tra lontani monti,

Dopo il giorno sereno,

Cadendo si dilegua, e par che dica

Che la beata gioventù vien meno.

\section{Recém-chegado e só}

A essa remota parte da campina, Cada deleite e jogo

Adio sempre; e todavia o olhar,

Distenso no ar radiante,

Fere-me o sol que ao longe, entre as montanhas,

Depois que o dia aquece,

Caindo some, e diz-me, agonizante,

Que a casta juventude desfalece. 
Assim como o pardal, o solitário poeta também se desloca em direção à campina; protelando a outro tempo as brincadeiras e a diversão. E é nesse momento, em que está só e pensativo, que a luz do sol atinge seus olhos, criando um efeito de ofuscamento, mas curiosamente a luz não o impede de ver a verdade: que a casta juventude também tramonta e desfalece, assim como a luz do sol, após um dia sereno, tramontando desvanece, entre as montanhas.

Os últimos versos desse período põem fim à festa da vila e em particular à festa da vida, dando lugar a uma imagem de melancolia e de caducidade das coisas.

Graças ao ritmo lento do verso 37 e da presença do gerúndio "uscendo" no fím do verso, cria-se um efeito brando do caminhar da personagem. Tal efeito não é mantido na tradução em português, tratando-se de um verso de ritmo mais acelerado e por ter a substituição do gerúndio por uma expressão estática, "recém-chegado".

\section{Terceira estrofe: o pássaro e o poeta}

Na última estrofe do poema, não é mais o comportamento semelhante, conforme visto até então nesta análise, a temática dos versos. Na terceira estrofe, dividida em duas partes, surgem as diferenças entre as personagens: o pardal e o poeta.

A primeira parte refere-se ao modo de vida do pássaro:

$45 \mathrm{Tu}$, solingo augellin, venuto a sera

Del viver che daranno a te le stelle, Certo del tuo costume

Non ti dorrai; che di natura è frutto

Ogni vostra vaghezza.
A ti, ave sozinha, quando à noite Da vida te levarem as estrelas, Lembrar o teu costume Não doerá, pois da natureza é fruto Teu apetite antigo.

Considerando o pôr do sol como o fim da vida ${ }^{88}$, o eu-lírico volta sua atenção ao “anoitecer" do passarinho. Certamente ao chegar ao fim de sua vida, o pardal solitário não terá

\footnotetext{
${ }^{88}$ Leopardi defente tal ideia no Zibaldone: "Nella mia vita infelicissiama l'ora meno trista è quella [152] del levarmi. Le speranze e le illusioni ripigliano per pochi momenti un certo corpo, ed io chiamo quell'ora la gioventù della giornata per questa similitudine che ha colla gioventù della vita. E anche riguardo alla stessa giornata, si suol sempre sperare di passarla meglio della precedente. E la sera che ti trovi fallito di questa speranza e disingannato, si può chiamare la vecchiezza della giornata." (4 Luglio 1820)
} 
motivos para lamentar-se - por ter vivido sem aproveitar sua juventude, à diferença dos demais pássaros - porque tudo aquilo que as criaturas fazem, por mais estranho que possa ser, é um fato natural. Logo, o pardal solitário, enquanto animal, vive instintivamente, sendo suas escolhas inconscientes, o que o levará a não se angustiar no futuro.

A combinação da expressão poética "solingo", juntamente com um diminutivo afetivo também poético “augelin" ${ }^{89}$, inspira ternura, mas se trata de uma ternura melancólica, pois a condição natural do pássaro é a desejada pelo poeta, que, ao contrário, é dominado pela razão. Essa combinação de expressões poéticas perde-se na tradução, já que "ave sozinha" não possui o mesmo valor expressivo dos termos do original ${ }^{90}$.

No período que conclui o poema, a atenção do eu-lírico volta-se à ciência humana

50A me, se di vecchiezza

La detestata soglia

Evitar non impetro,

Quando muti questi occhi all'altrui core, E lor fia vóto il mondo, e il dì futuro

55Del dì presente più noioso e tetro,

Che parrà di tal voglia?

Che di quest'anni miei? che di me stesso?

Ahi pentirommi, e spesso,

Ma sconsolato, volgerommi indietro.
A mim, se não consigo

Da velhice evitar

O tão doloroso umbral,

Quando este olhar emudecer às almas, E lhe for erma a terra, e o seu futuro

Do que o presente mais tedioso e horrendo, Que direi desse afã?

E destes anos meus? O que de mim?

Terei remorso, enfim, $\mathrm{E}$, triste, irei então retrocedendo.

\footnotetext{
"Na minha vida infelicíssima a hora menos triste é aquela [152] do levantar-me. As esperanças e as ilusões retomam por poucos momentos um certo corpo, e eu chamo aquela hora de juventude do dia por esta similitude que tem com a juventude da vida. E também referente ao mesmo dia, costuma-se sempre esperar passá-lo melhor do que o precedente. E a noite que te vê privado desta esperança e desenganado, pode-se chamar a velhice do dia." (4 de Julho de 1820) - [Trad. nossa]

${ }^{89} \mathrm{O}$ uso de diminutivo é frequente nos poemas de Leopardi: augellin, donzelletta, vecchierella, garzoncello, giovinetta entre outros. Para o poeta, tal uso serve a demonstrar o afeto dedicado à pessoa ou à coisa, conforme explica no Zibaldone:

"Una prova evidente e popolare frequente nella vita, e giornaliera, che il piccolo è considerato come grazioso, si è il vezzo dei diminutivi che sogliono applicare alle persone o cose che si amano, o si vogliono vezzeggiare, pregare, addolcire, descrivere come graziose ec. [250] - (22 Settembre 1820)."

"Uma prova evidente e popular, quotidiana e frequente na vida de que o pequeno é considerado como gracioso, temse com o uso dos diminutivos que costumam aplicar às pessoas ou coisas que se amam, ou se quer adular, rogar, adoçar, descrever como graciosas etc". [250] - (22 de Setembro de 1820) - [Trad. nossa]

${ }^{90}$ Para manter em parte a expressividade poética, poder-se-ia substituir o verso 45 por "Solitária avezinha, quando à noite", substituindo a palavra "ave" pelo seu diminutivo, tão caro a Leopardi como já visto, podendo deslocar a expressão "a ti" para o verso 48, ficando "Não te doerá, pois é natural fruto", substituindo a locução adjetiva, "da natureza" pelo adjetivo "natural".
} 
Bem diferente da condição do pássaro é a situação do poeta. Esse, dotado de razão e, portanto de liberdade de escolha, ao chegar em sua velhice, angustiar-se-á por ter a consciência de não ter vivido da melhor forma a sua juventude.

Interessante é o verso 54, “Quando muti questi occhi all'altrui core”, em que, em poucas palavras, consegue-se criar um efeito de desolada tristeza que o homem sentirá ao chegar à velhice. Esses olhos, além de não conseguirem inspirar mais nada aos demais homens, também não conseguirão encantar-se com a beleza do infinito; e os dias futuros mostrar-se-ão mais molestos e tetros.

Leopardi, no Zibaldone, [4284], escreve sobre a temida aridez dos sentimentos quando na velhice:

“É ben trista quella età nella quale l'uomo sente di non ispirar più nulla. Il gran desiderio dell'uomo, il gran mobile de' suoi atti, delle sue parole, de' suoi sguardi, de' suoi contegni fino alla vecchiezza, è il desiderio d'inspirare, di comunicare qualche cosa di se agli spettatori o uditori ${ }^{91}$." (1º Luglio 1827)

Ao longo de todo o período, é possível perceber a predominância dos sons das consoantes oclusivas /p/, /b/, /t/, /d/, /k/ e /g/, aliados às vibrantes /r/. Por ser um tipo de som em que durante sua pronúncia o ar expirado é bloqueado por um obstáculo bucal, que interrompe momentaneamente a sua corrente, e que acaba "explodindo" quando aberto, o efeito criado é de desaceleração do ritmo, e ao mesmo tempo de dureza, propagando um tom de pessimismo e de lamento na conclusão do poema; efeitos bem recriados por Ivan Junqueira em sua tradução $O$ pardal solitário.

Após pensar sobre o solitário declinar, o poeta questiona-se sobre a sua escolha de viver em solidão, passando, assim, à melhor fase de sua vida. Triste é a mensagem final do canto, já

\footnotetext{
91 "É bem triste aquela idade na qual o homem sente que não pode inspirar mais nada. O grande desejo do homem, o grande motivo de seus atos, de suas palavras, de seus olhares, de seus modos até a velhice, é o desejo de inspirar, de comunicar alguma coisa de si aos espectadores ou ouvintes." (1º de julho de 1827) - [Trad. nossa]
} 
que o poeta não terá nem mesmo a esperança de um consolo, visto que o tempo perdido não volta mais, e só o que lhe restará será o próprio arrependimento.

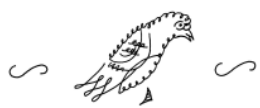

${ }^{92}$ Giacomo Leopardi desenhava sempre as páginas de rosto ou as últimas páginas de seus manuscritos. Entre os vários motivos dos frisos ou dos desenhos, o mais recorrente era aquele de um pássaro. O desenho acima é uma reprodução do original, feita por nós, conforme visto na exposição I mondi di Giacomo na casa Leopardi em Recanati (20/09/2009). 
3.2 UM PASSEIO NO INFINITO

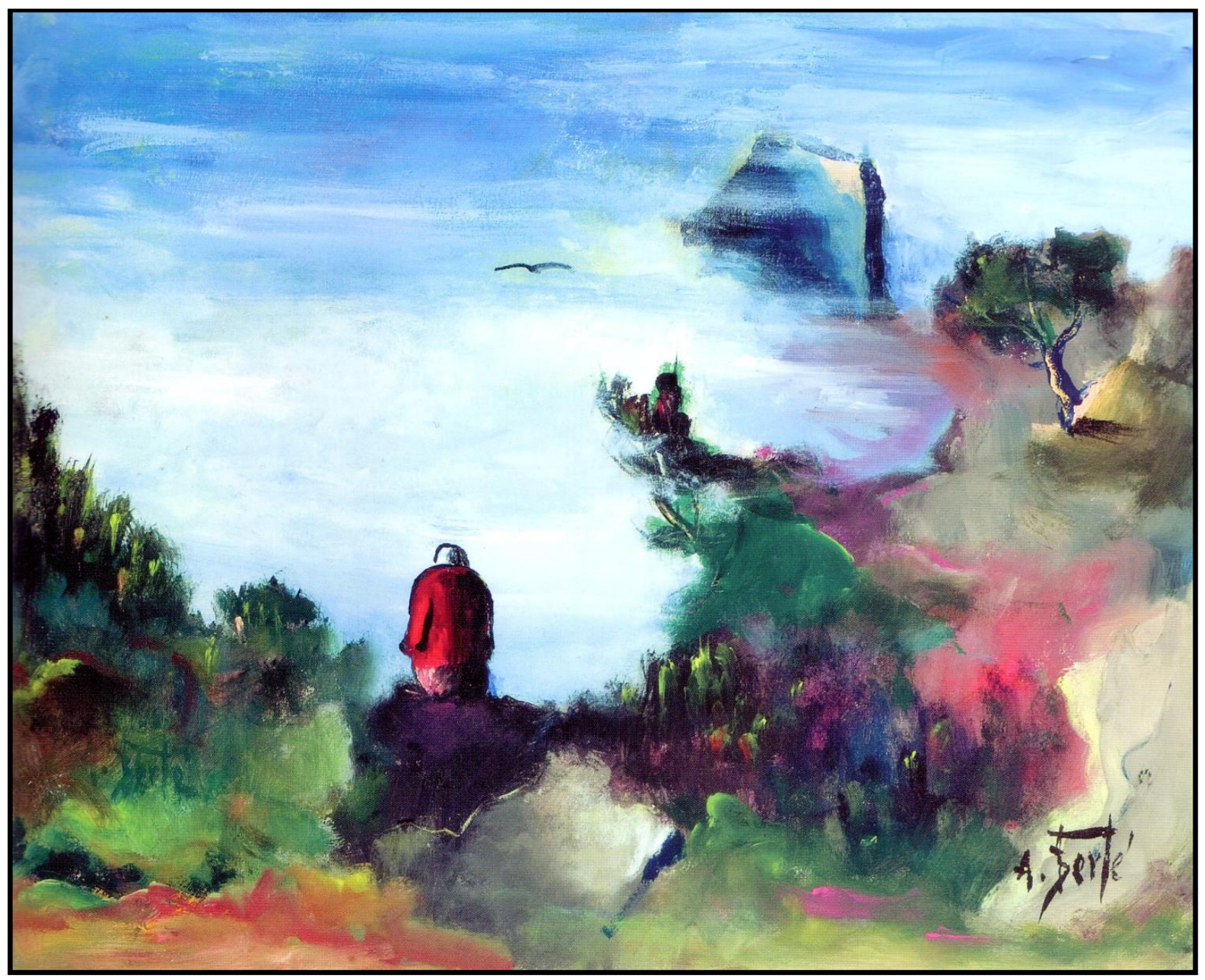

L'INFINITO - Antonio Bertè 


\subsection{UM PASSEIO NO INFINITO: pessimismo histórico}

O ano de 1819 foi decididamente muito importante para a formação do pensamento leopardiano. Vários foram os acontecimentos que tornaram esse ano marcante: a tentativa de fuga de Recanati; o início de uma grave moléstia nos olhos; a conversão filosófica, entre outros fatos.

Leopardi, sentindo-se cada vez mais infeliz, como já visto tanto no âmbito familiar, quanto no ambiente recanatense, começa a provar uma sensação de aflição implacável. O poeta cada vez mais se convencia de que fora de Recanati, poderia provar tudo aquilo que aprendera por meio de suas experiências livrescas; conheceria um mundo vivo e cheio de paixões, onde poderia encontrar uma sociedade mais receptiva às manifestações do engenho e da arte. Seus planos culminam numa tentativa de fuga de Recanati, em 1819. Todavia, devido a uma denúncia feita por um tio de Giacomo, seu pai Monaldo fica sabendo de sua intenção, o que acaba abortando os planos do poeta.

Nesse mesmo ano, Giacomo Leopardi é vítima de uma forte oftalmia, a qual o obriga a renunciar até mesmo as suas tão prazerosas leituras. Sendo assim, vendo-se prisioneiro de um ambiente adverso, sem poder refugiar-se nem mesmo entre seus estudos, aumenta em Leopardi um forte sentimento de melancolia e solidão.

Durante os estudos juvenis, prevalecia em Leopardi o interesse pela erudição, para o gosto superficialmente francelho, além da inclinação à poesia arcádica. Por volta de 1815-16, acontece uma mudança de foco no poeta, a qual ele mesmo chama "conversione estetica" (conversão estética), ou seja, a passagem do erudito ao belo. Com isso, Leopardi abandona o gosto pela erudição, direcionando sua atenção totalmente à poesia, mais precisamente aos clássicos, vistos não mais como material filológico, mas como modelo de poesia a ser seguido. Leopardi começa a refletir sobre a literatura e sobre a função do intelectual, iniciando a se destacar da educação paterna e a sentir a angústia da cultura recanatense. Trata-se da descoberta do belo no sentido neoclássico. No ano seguinte, 1817, passa a fazer parte da vida do poeta uma importante figura, Pietro Giordani, famoso escritor classicista, com quem passará a trocar inúmeras 
correspondências. A amizade com Giordani permitiu que Leopardi entrasse em contato com a cultura existente fora de Recanati, com as ideias de um classicismo progressista, anticlerical, a favor de uma renovação nacional. Com isso, Leopardi começa a desenvolver uma nova ideologia e sensibilidade. É o início de uma nova mutação: “conversione filosofica” (conversão filosófica), ou seja, a passagem do belo ao real, da poesia à filosofia. Tal mutação se completará em 1819, como o próprio Leopardi afirma no Zibaldone ${ }^{93}$. Em relação a essas mutações Leopardi diz:

"Il mio passaggio però dall'erudizione al bello non fu subitaneo, ma gradato, cioè cominciando a notar negli antichi e negli studi miei qualche cosa più di prima ec. Così il passaggio dalla poesia alla prosa, dalle lettere alla filosofia. ${ }^{94, "}(19$ settembre 1821$)$

Nesse período, Leopardi elabora a base de sua filosofia, refletindo sobre o contraste entre a natureza e a razão, entre os antigos e os modernos; descobrindo a inutilidade das esperanças e a existência da dor inelutável, descobertas que culminam na revelação da nulidade das coisas - é o início do pessimismo histórico de Leopardi.

Influenciado pela leitura de Rousseau, Leopardi acredita no contraste existente entre a natureza benéfica, em que reina a beleza, a poesia e as ilusões, e a razão maléfica, que leva à realidade, tornando árida a poesia e destruindo as ilusões; contraste que produz a infelicidade do gênero humano.

Por volta de 1817-18, no Zibaldone [14-15] Leopardi diz:

La ragione è nemica d'ogni grandezza: la ragione è nemica della natura: la natura è grande, la ragione è piccola. Voglio dire che un uomo tanto meno o tanto più difficilmente sarà grande, quanto più sarà dominato dalla ragione: ché pochi possono esser grandi (e nelle arti e nella poesia forse nessuno) se non sono dominati dalle illusioni [...] e noi siamo nel secolo della ragione: (non per altro se non perché il mondo più vecchio ha più sperienza e freddezza) e pochi ora possono essere e sono gli uomini grandi, segnatamente nelle arti. Anche chi è veramente grande, sa pesare adesso e conoscere la sua grandezza [...] anche le illusioni ora si conoscono chiarissimamente

\footnotetext{
${ }^{93}$ Zib., [144], 2 de julho de 1820.

94 "A minha passagem, todavia, da erudição ao belo não foi súbita, mas gradual, ou seja, começando a notar nos antigos e nos meus estudos alguma coisa a mais do que antes etc. Assim, a passagem da poesia à prosa, das letras à filosofia." (19 de setembro de 1821) - [Trad. nossa]
} 
esser tali [...]. Ora come è possibile che sieno durevoli e forti quanto basta, essendo così scoperte? e che muovano a grandi cose? e, senza le illusioni qual grandezza ci può essere o sperarsi? $?^{95}$

Para Leopardi, a natureza é uma entidade benéfica, não tanto por oferecer ao homem uma condição feliz, mas porque the doa sólidas e generosas ilusões, as quais o tornam capaz de grandes atos. Todavia, a razão - representada pela sociedade, civilização e história - por meio do conhecimento, destrói as ilusões dos homens, demonstrando-lhes a sua verdadeira condição na terra: de infelicidade.

Outra antítese apresentada por Leopardi é a de antigos versus modernos. A simpatia do poeta é direcionada aos antigos, donos de uma férvida imaginação, capazes de sentir, de fantasiar e de acreditar nas ilusões oferecidas pela natureza. Enquanto que os modernos, dominados pelo conhecimento, perderam a fantasia e a capacidade de se iludirem, vivendo assim numa condição de infelicidade.

Fazendo um paralelo entre os antigos e os modernos com a vida de cada indivíduo, Leopardi aproxima os antigos aos garotos, enquanto que os modernos representam a fase adulta dos homens. Os primeiros se distinguem pela inocência, pelo temor diante do desconhecido, pela ignorância, pelos prazeres sentidos, pelas crenças e pela capacidade de fantasiar. Já nos segundos, devido ao domínio da razão, o reino da fantasia vai progressivamente se restringindo, culminando no fim do uso da imaginação.

Conforme afirma Leopardi no Discurso di un italiano intorno alla poesia romantica ${ }^{96}$ (1818):

le immagini fanciullesche e la fantasia che dicevamo, sono appunto le immagini e la fantasia degli antichi, e le ricordanze della prima età e le idee prime nostre

\footnotetext{
95 “A razão é inimiga de toda grandeza: a razão é inimiga da natureza: a natureza é grande, a razão é pequena. Quero dizer que um homem tanto menos ou tanto mais dificilmente será grande, quanto mais será dominado pela razão: porque poucos podem ser grandes (e nas artes e na poesia talvez ninguém) se não são dominados pelas ilusões [...] e nós estamos no século da razão: (não por outro motivo se não porque o mundo mais velho tem mais experiência e frieza) e poucos agora podem ser e são os homens grandes, particularmente nas artes. Até quem é realmente grande, sabe ponderar agora e conhecer a sua grandeza [...]agora conhece-se clarissimamente até as ilusões [...] Agora, como é possível que sejam duráveis e fortes o suficiente, sendo assim expostas? e que movam a grandes coisas? e, sem as ilusões qual grandeza pode existir ou se esperar? "[Trad. nossa]

${ }^{96}$ LEOPARDI, G. Discorso di un italiano intorno alla poesia romantica. Org. Ottavio Besomi; Bellinzona: Edizioni Casagrande, 1988.
} 
che noi siamo così gagliardamente tratti ad amare e desiderare, sono appunto quelle che ci ridesta l'imitazione della natura schietta e inviolata, quelle che ci può e secondo noi ci deve ridestare il poeta, quelle che ci ridestano divinamente gli antiche, quelle che i romantici bestemmiano e rigettano e sbandiscono dalla poesia, gridando che non siamo più fanciulli: e pur troppo non siamo: ma il poeta deve illudere, e illudendo imitar la natura, e imitando la natura dilettare [...]. Che natura o che leggiadra illusione speriamo di trovare in un tempo dove tutto è civiltà, e ragione e scienza e pratica e artifizi; [...] quando la maraviglia è vergogna; [...] quando il cuor nostro o disingannato dall'intelletto non palpita, o se anche palpita, corre tosto l'intelletto a ricercargli e frugargli tutti i segreti di questo palpito, e svanisce ogn'illusione svanisce ogni dolcezza svanisce ogni altezza di pensieri; [...] quando la scienza dell'animo umano già certa e quasi matematica e risolutamente analitica, secondo l'idioma scolastico de' moderni, per poco non s'espone con angoli e cerchi, e non si tratta per computi e formole numerali ${ }^{97}$ ? $(1988: 20)$

Nessa passagem, além de o poeta deixar clara a sua simpatia em relação aos antigos, também especifica a qual "mundo" pertence a poesia. Para ele, a poesia pertence ao "mundo da natureza", que é da sensibilidade, da fantasia e do instinto; não podendo, portanto, existir poesia no "mundo da razão", em que reinam temáticas realísticas, científicas e modernas.

Mais adiante, por volta de 1820, Leopardi reflete sobre a passagem da poesia à filosofia. No Zibaldone [144] ele diz:

“poeti non erano se non gli antichi, e non sono ora se non i fanciulli, o giovanetti, e i moderni che hanno questo nome, non sono altro che filosofi. Ed io infatti non divenni sentimentale, se non quando perduta la fantasia divenni insensibile alla natura, e tutto dedito alla ragione e al vero, in somma filosofo. ${ }^{98, "}$ (2 Luglio 1820)

\footnotetext{
97، As imagens infantis e a fantasia que dizíamos são exatamente as imagens e a fantasia dos antigos, e as lembranças da primeira idade e as primeiras ideias nossas que nós somos tão fortemente atraídos a amar e a desejar, são justamente aquelas despertadas em nós pela imitação da natureza pura e inviolada, aquelas que na nossa opinião pode, ou melhor deve, reavivar em nós o poeta, aquelas que reavivam em nós divinamente os antigos, aquelas que os românticos blasfemam e rejeitam e repudiam da poesia, gritando que não somos mais garotos: e infelizmente não somos: mas o poeta deve iludir, e iludindo imitar a natureza, e imitando a natureza deleitar [...]. Qual natureza ou qual garbosa ilusão esperamos encontrar em um tempo onde tudo é civilização, e razão e ciência e prática e artifícios; [...] quando a maravilha é vergonha; [...] quando o nosso coração ou desenganado pelo intelecto não palpita, ou mesmo se palpita, logo corre ao intelecto para rebuscar e revirar todos os segredos dessa palpitação, e esvanece cada ilusão, esvanece cada doçura, esvanece cada grandeza de pensamentos; [...] quando a ciência da alma humana já certa e quase matemática e resolutamente analítica, conforme o idioma escolástico dos modernos, por pouco não se expõe com ângulos e círculos, e não se trata por cálculos e fórmulas numerais?" [Trad. nossa]

98 "poetas não foram senão os antigos, e não são agora senão os garotos, os jovenzinhos, e os modernos, que têm esse nome, não são outra coisa do que filósofos. E eu de fato não me tornei sentimental, senão quando perdida a fantasia me tornei insensível à natureza, e todo dedicado à razão e ao real, em suma filósofo.” (2 de julho de 1820) - [Trad. nossa]
} 
Para ele, diferentemente da poesia dos antigos, considerada como a verdadeira poesia, nos modernos vê-se uma poesia-filosófica - por ser inevitavelmente reflexiva, priva de ingenuidade e de naturalidade, já que a consciência racional atrofiou a imaginação e cortou a ligação com a natureza. Desse modo, não resta ao poeta moderno (chamado de filósofo) que cantar o seu sentimento lamuriante em relação à ingenuidade e à harmonia perdidas.

Uma das grandes causadoras da infelicidade humana teria sido, portanto, para Leopardi, a razão, já que ela fez cair os véus da ilusão dos homens. Todavia, o poeta identifica outra grande causadora: a sociedade. Ele chega a tal conclusão, analisando a história. Sabe-se que o gênero humano teve como primeiros inimigos naturais as feras e os elementos. Enquanto durou o sentimento de temor por esses inimigos, os homens não se voltaram uns contra os outros, pelo contrário, iniciaram a procurar a companhia e a ajuda de outros. Com o tempo, eles fabricaram armas e construíram cidades para se defenderem dos ataques dos animais, mas aos poucos, vendo-se vencedores de seus inimigos, e tornando-se prósperos, os homens foram voltando suas próprias armas contra outros da mesma espécie.

O homem, uma vez agrupado em sociedade e por meio da conversação, foi instruindo-se, acostumando-se a refletir sobre si mesmo, a comparar, a pensar, o que causou aos poucos a perda de suas ilusões. Tal comportamento não se reduz em um único indivíduo: "come negl'individui, così ne' popoli, e come ne' popoli, così nel genere umano ridotto allo stato sociale ${ }^{99, "}$.

Leopardi conclui que se o homem tivesse continuado a viver isolado, como no princípio, ele não teria perdido as suas ilusões juvenis, conservando-as por toda a vida, e consequentemente teria uma vida feliz. Portanto a causa originária da infelicidade humana teria sido a sociedade, já que o homem, conforme a natureza, teria vivido isolado e longe da sociedade ${ }^{100}$.

Extremamente importante para a filosofia leopardiana é a força da imaginação. Já que é por meio dela que o homem pode representar em seus pensamentos infinitos prazeres, servindo

\footnotetext{
${ }^{99} \mathrm{e}^{8}$ (Zib., $2684-1^{\circ}$ Aprile 1823). "Como nos indivíduos, assim nos povos, e como nos povos, assim no gênero humano reduzido ao estado social". [Trad. nossa]
} 
de compensação à realidade infeliz e tediosa em que está inserido. A base de tal afirmação encontra-se na "teoria del piacere" (teoria do prazer), assim chamada pelo próprio Leopardi.

Em 1820, no Zibaldone [165], Leopardi diz:

L'anima umana (e così tutti gli esseri viventi) desidera sempre essenzialmente, e mira unicamente, benchè sotto mille aspetti, al piacere, ossia alla felicità, che considerandola bene, è tutt'uno col piacere. [...] Il detto desiderio del piacere non ha limiti per durata, perchè, come ho detto non finisce se non coll'esistenza, e quindi l'uomo non esisterebbe se non provasse questo desiderio. Non ha limiti per estensione perch'è sostanziale in noi, non come desiderio di uno o più piaceri, ma come desiderio del piacere. $^{101}$

O homem, bem como todos os seres vivos, almeja o prazer, ou seja, a felicidade. Todavia, esse desejo do prazer não possui limites nem duração, portanto, ele se transforma em um prazerinfinito (prazer grifado pelo autor - il piacere - para diferenciá-lo do prazer acessível aos homens). A grande problemática é que o mundo é limitado, portanto, tudo que circunda os seres vivos não pode satisfazer por completo o desejo infinito do prazer que eles têm. Sendo assim, o homem é destinado à infelicidade, dado o contraste existente entre o infinito desejo versus a limitação do mundo.

Para Leopardi faz-se mister considerar, neste ponto, o caráter misericordioso da natureza, a qual, não podendo oferecer aos homens e aos seres vivos nenhum prazer real infinito, proporciona-lhes a faculdade imaginativa, de modo que eles possam representar prazeres inexistentes, infinitos no número, na duração e na extensão ${ }^{102}$; além de oferecer-lhes a ocupação,

101 "A alma humana (e assim todos os seres vivos) deseja essencialmente e almeja unicamente (posto que sob inúmeros aspectos) o prazer, ou seja, a felicidade, que se observarmos bem, identifica-se com o prazer. [...] $\mathrm{O}$ referido desejo do prazer não tem limites de duração, porque, como disse, confina com a existência, logo, o homem não existiria se não experimentasse esse desejo. Não tem limites de extensão porque é essencial em nós, não como desejo de um ou mais prazeres, mas como desejo do prazer." [Trad. LUCCHESI, 1996, p.644]

102 "Indipendentemente dal desiderio del piacere, esiste nell'uomo una facoltà immaginativa, la quale può concepire le cose che non sono, e in un modo in cui le cose reali non sono. Considerando la tendenza innata dell'uomo al piacere, è naturale che la facoltà immaginativa faccia una delle sue principali occupazioni della immaginazione del piacere. E stante la detta proprietà di questa forza immaginativa, ella può figurarsi dei piaceri che non esistano, e figurarseli infiniti 1. in numero, 2. in durata, 3. e in estensione. Il piacere infinito che non si può trovare nella realtà, si trova così nella immaginazione, dalla quale derivano la speranza, le illusioni ec.” Zib. [167] - (12-23 Luglio 1820) "Independentemente do desejo do prazer, existe no homem uma faculdade imaginativa, que pode conceber coisas que não existem e de uma forma que as coisas reais não existam. Considerando a tendência inata do homem para o prazer, é natural que a faculdade imaginativa faça da imaginação do prazer uma de suas principais ocupações. E em vista da referida propriedade dessa força imaginativa, ela pode conceber prazeres que não existem e concebê-los 
de modo que eles não tenham tempo para refletir sobre a incapacidade de satisfazer todos os prazeres, já que uma vez desenganados de um prazer recorrem a outro, confundindo-se com a grande variedade de coisas existentes.

Entre os imaginários prazeres criados pelo homem, os mais eficazes são aqueles que suscitam sensações indefinidas, que vão além do espaço e do tempo, pois ao invés de se basearem na visão concreta, baseiam-se na imaginação, fugindo do real.

Imagens indefinidas são aprazíveis, pois criam múltiplas sensações, que acabam confundindo a alma pois elas a impedem de ver os confins, removem-lhe o esgotamento imediato do prazer, além de a fazerem errar de um prazer ao outro de modo que não se fixe em nenhum, assemelhando-se a um prazer-infinito.

infinitos: 1 - em número, 2 - em duração, 3 - em extensão. O prazer infinito, que não se pode encontrar na realidade, encontra-se dessa forma, na imaginação, de que derivam a esperança, as ilusões, etc.” [Trad. LUCCHESI, 1996, p. 645] 


\subsubsection{L'INFINITO de Leopardi no Brasil}

\section{"L’Infinito"}

Sempre caro mi fu quest'ermo colle, E questa siepe, che da tanta parte Dell'ultimo orizzonte il guardo esclude. Ma sedendo e mirando, interminati 05Spazi di là da quella, e sovrumani Silenzi, e profondissima quiete Io nel pensier mi fingo; ove per poco Il cor non si spaura. E come il vento Odo stormir tra queste piante, io quello 10Infinito silenzio a questa voce Vo comparando: e mi sovvien l'eterno, E le morte stagioni, e la presente E viva, e il suon di lei. Così tra questa Immensità s'annega il pensier mio: $15 \mathrm{E}$ il naufragar m'è dolce in questo mare.

[Giacomo Leopardi]

\section{"O Infinito"}

Sempre cara me foi esta colina

Erma e esta sebe, que de extensa parte

Dos confins do horizonte o olhar me oculta. Mas, se me sento a olhar, intermináveis Espaços para além, e sobre-humanos Silêncios e quietudes profundíssimas, Na mente vou sonhando, de tal forma Que quase o coração me aflige. E, ouvindo $O$ vento sussurrar por entre as plantas, $\mathrm{O}$ silêncio infinito à sua $\mathrm{voz}$ Comparo: é quando me visita o eterno E as estações já mortas e a presente E viva com seus cantos. Assim, nessa Imensidão se afoga o pensamento: E doce é naufragar-me nesses mares.

[Tradução de Ivo Barroso]

Composto em 1819, L'Infinito foi publicado pela primeira vez no $12^{\circ}$ número da revista Nuovo Ricoglitore, em dezembro de 1825. No ano seguinte, saiu a edição bolonhense dos "Versi", em que estão publicados seis idílios de Leopardi, com L'Infinito abrindo a sequência, para enfim ser publicado na edição florentina dos Canti, em 1831.

Consta, no primeiro autografo ${ }^{104}$, a denominação “Idillio" para o poema L'Infinito. Por idílio entende-se uma pequena composição poética de caráter campestre ou pastoril ${ }^{105}$. Acreditase que Leopardi tenha utilizado tal expressão, inspirado no quinto idílio de Mosco, obra traduzida por ele, mas a significação do idílio leopardiano é bem diferente da do tradicional: Leopardi recupera uma forma poética do passado, dando-lhe novas características, tanto estruturais como

103 Constam na edição de referência várias traduções do poema L'Infinito: de Ivo Barroso; de Mário Faustino; de Vinícius de Moraes e de Haroldo de Campos . Escolheu-se aqui analisar àquela de Ivo Barroso, posta em destaque no corpo do livro, visto que as demais estão no apêndice.

104 http://www.bnnonline.it/biblvir/inf1rlr.htm ("Biblioteca Nazionale di Napoli" autógrafo on-line; acesso em 03/02/2010 às $18 \mathrm{~h})$.

${ }^{105}$ Dicionário Aurélio Eletrônico - Século XXI - Versão 3.0 - Novembro de 1999. 
temáticas. Dessa forma cria um efeito expressivo da lembrança, recuperando a condição original da poesia.

Do ponto de vista formal, o poema é composto de uma única estrofe de quinze versos brancos, sendo todos decassílabos, na contagem métrica brasileira. Em sua extensão, possui um ritmo lento, desacelerado graças a recursos expressivos: polissíndetos (repetição da conjunção “e”), acrescentando elementos coordenados regidos por um único verbo que interrompem temporariamente a ação; enjambement (ruptura de uma unidade sintática entre dois versos) que cria um efeito de alongamento do verso; além da vasta presença de pontuação (vírgula - ponto-evírgula - dois pontos) que sugere uma pausa na leitura.

A análise a seguir será feita em quatro etapas, conforme a divisão dos períodos no poema. A primeira apresenta uma visão concreta do mundo em que vive o poeta; a segunda distancia o poeta do mundo real, aproximando-o, por meio da imaginação, a um mundo ultrarreal, onde se depara com o infinito espacial; na terceira, tem-se uma recuperação do real, mas que ao mesmo tempo sugere ao poeta o encontro com o infinito temporal; para na quarta parte, ter a entrega da personagem ao infinito espaço-temporal.

No primeiro período, percebe-se a ligação do poeta com um mundo que o circunscreve.

Sempre caro mi fu quest'ermo colle, E questa siepe, che da tanta parte Dell'ultimo orizzonte il guardo esclude.
Sempre cara me foi esta colina Erma e esta sebe, que de extensa parte Dos confins do horizonte o olhar me oculta.

Sempre cara foi ao poeta uma colina - identificada pela crítica como sendo o Monte Tabor, localizado próximo à residência Leopardi - onde tinha costume de ir, dada a colocação do

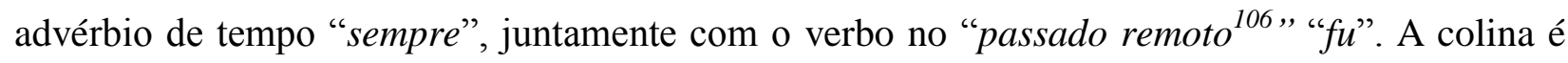
cara ao poeta por se tratar de um lugar ermo, onde pode estar tranquilo e em contato com a natureza. Nessa colina encontra-se uma sebe, a qual o impede de observar uma extensa parte dos confins do horizonte. O fato de a sebe representar um obstáculo para a contemplação da paisagem, estimula o trabalhar da imaginação do poeta, e é por isso que também a considera cara.

\footnotetext{
${ }^{106}$ Passato remoto - é um tempo simples equivalente ao pretérito perfeito do português. Indica uma ação acontecida num passado distante ou até mesmo próximo.
} 
Rica é a presença dos pronomes demontrativos "questo" e "quello" ao longo do poema; já nos primeiros dois versos aparecem duas vezes ("questo" e "questa") ligados aos substantivos "colle" e "siepe". Os pronomes demonstrativos, gramaticalmente definidos, indicam a relação de proximidade (questo) e de afastamento (quello) de coisas, ou pessoas, de quem fala. Sendo assim, o uso desses pronomes no primeiro período aproxima o eu-lírico ao seu mundo real - concreto; tal efeito é mantido na tradução de Ivo Barroso.

Percebe-se uma inversão no primeiro verso tanto do sujeito em relação ao verbo e ao seu complemento (Sempre caro mi fu quest'ermo colle, / Quest'ermo colle mi fu sempre caro,); quanto do adjetivo em relação ao substantivo (ermo colle / colle ermo). Trata-se de um recurso criado talvez para colocar o substantivo "colle" em uma posição de destaque, posto no fim do verso, sugerindo assim o seu isolamento. Ivo Barroso reproduz a inversão do verso (Sempre cara me foi esta colina / Esta colina me foi sempre cara) deixando também o substantivo "colina" em posição de destaque, mas opta por não inverter o adjetivo em relação ao substantivo, talvez por efeito da métrica, já que colina é uma palavra trissilábica enquanto erma é dissilábica. Para compensar o efeito presente no poema original, Ivo Barroso desloca o adjetivo "erma" para o segundo verso, criando um efeito espaçado, dilatando o significado da palavra "erma", além de provocar uma pausa na leitura logo no início do segundo verso.

Curioso é o fato de que a "siepe" fixa um limite no mundo real, mas, ao mesmo tempo, estimula por meio da imaginação o superamento desses limites, atingindo a infinitude. E é esse mundo ultrarreal que o poeta descobre no segundo período do poema.

Ma sedendo e mirando, interminati 05Spazi di là da quella, e sovrumani

Silenzi, e profondissima quiete

Io nel pensier mi fingo; ove per poco

Il cor non si spaura. E come il vento
Mas, se me sento a olhar, intermináveis Espaços para além, e sobre-humanos Silêncios e quietudes profundíssimas, $\mathrm{Na}$ mente vou sonhando, de tal forma Que quase o coração me aflige. E, ouvindo

Contrastando com o período interior, tem-se a presença de uma conjunção adversativa "Ma", abrindo o verso 4, a qual, gramaticalmente, liga dois termos ou duas orações de função idêntica, estabelecendo, porém, uma ideia de contraste. No poema em questão, a conjunção " $m a$ " 
está ligando dois mundos opostos: o mundo real, descrito na primeira parte do poema, onde se encontra fisicamente o poeta; e o mundo ultrarreal, criado por sua imaginação.

Dois são os verbos - usados no gerúndio - que marcam a passagem de um mundo ao outro: "sedendo e mirando", sendo o primeiro ligado a uma dimensão física; enquanto o segundo, a uma dimensão espiritual. Na tradução em português, a paranomásia não foi mantida, substituída pelas expressões "se me sento a olhar". A presença da conjunção "se" sugere o domínio do poeta em relação aos seus sentimentos e às suas ilusões, enfraquecendo o efeito criado no poema original de algo que brota naturalmente da imaginação.

Aquilo que o poeta vê, com seus olhos da mente, são espaços maximamente ampliados, que vão além dos confins do horizonte. A presença do demonstrativo "quella" marca o distanciamento do poeta do mundo real. Ele não está mais mentalmente próximo à sebe ("questa siepe"): graças à imaginação, ele percorre um voo que o leva além do horizonte ("di là da quella") ${ }^{107}$.

Na mente, tudo se dilata: os espaços, os silêncios e a quietude. A série de enjambements presentes nos versos 4, 5 e 6, ampliam esse efeito, além da escolha dos adjetivos polissilábicos (“interminati - sovrumani - profondissima”), recursos que são mantidos na tradução de Ivo Barroso.

Interessante é o verso 7, colocado em posição central no poema, em que o poeta diz "io nel pensier mi fingo", o qual ganha uma forte carga erudita, graças à escolha do verbo "mi fingo". "Fingere", no sentido douto, significa plasmar com a imaginação, ou seja, o poeta atinge o ponto mais alto de seus pensamentos, sentindo em sua imaginação um infinito espacial. Ao atingir a infinitude, isto é, a realidade que supera a compreensão para a mente humana, as sensações suscitadas parecem ser tão reais ao poeta que o seu coração se turva.

\footnotetext{
${ }^{107}$ Leopardi, no Zibaldone, afirma que:

"L'anima si immagina ciò che non vede, che quell'albero, quella siepe, quella torre le nasconde, e va errando in uno spazio immaginario, e si figura cose che non pobrebbe, se la sua vista si estendesse da per tutto perché il reale escluderebbe l'immaginario". (12 Luglio 1820)

"A alma não imagina aquilo que não vê, que aquela árvore, aquela sebe, aquela torre lhe esconde, e vai errando em um espaço imaginário, e figura coisas que não poderia, se a sua vista se estendesse por todos os lugares porque o real excluiria o imaginário". (12 de julho de 1820) - [Trad. nossa]
} 
Na tradução brasileira, a expressão "vou sonhando" substitui "mi fingo". Por mais que o verbo "sonhar" possa significar "imaginar", ele não tem o valor intensivo que o verbo "fingere" possui. Com essa tradução, as sensações imaginadas pelo eu-lírico, por pertencerem a um sonho, ganham características oníricas, portanto, não conseguem transmitir nas sensações suscitadas um ar "realístico", como visto acima.

Muito importante é para Leopardi a faculdade imaginativa em um poeta. No Zibaldone [4358] ele diz:

"Il poeta immagina: l'immaginazione vede il mondo come non è, si fabbrica un mondo che non è, finge, inventa, non imita, [...] creatore, inventore, non imitatore; ecco il carattere essenziale del poeta ${ }^{108}$." (29 Agosto 1828)

Aludindo a essa passagem leopardiana o crítico Haroldo de Campos chama a atenção para “o papel que Leopardi conferia à 'ilusão' na criação poética ('E se o poeta não pode iludir, não é mais poeta, é uma poesia razoável')". (1969, p.189) - Campos também apresenta nesse seu estudo uma sua tradução do poema L'infinito, e interessante é perceber que o crítico traduziu brilhantemente o verso 7, "Io nel pensier mi fingo" por "eu no pensar me finjo", conservando as características analisadas acima.

Após o primeiro contato com o mundo ultrarreal, o poeta volta a ter contato com o externo, no terceiro período do poema.

Il cor non si spaura. E come il vento

Odo stormir tra queste piante, io quello 10Infinito silenzio a questa voce

Vo comparando: e mi sovvien l'eterno, E le morte stagioni, e la presente

E viva, e il suon di lei. Così tra questa
Que quase o coração me aflige. E, ouvindo

O vento sussurrar por entre as plantas,

O silêncio infinito à sua voz

Comparo: é quando me visita o eterno

E as estações já mortas e a presente

E viva com seus cantos. Assim, nessa

108 “O poeta imagina: a imaginação vê o mundo como ele não é, constrói um mundo que não é, finge, inventa, não imita, [...] criador, inventor, não imitador; eis o caráter essencial do poeta" (29 de agosto de 1828) - [Trad. nossa] 
Assim que o poeta ouve o sussurrar do vento, sua atenção retorna ao mundo concreto, para em seguida distanciar-se novamente ao comparar a voz do vento a do infinito silêncio. Recria-se nesses versos o efeito do movimento do vento, o qual é ondular e dado pela presença dos demonstrativos "queste/quello/questa" que ora aproxima, ora distancia o poeta do mundo real. Percebe-se a forte presença de sons fricativos /f/ e /v/ e sonoros /s/ que recriam a ideia do soprar do vento, efeito que está também presente na tradução de Ivo Barroso.

$\mathrm{Na}$ tradução apresentada, o jogo do movimento não é recriado por meio dos demonstrativos, é o campo semântico que forma o efeito de aproximação e distanciamento do poeta, visto que ora apresenta elementos do mundo real ("vento/plantas") ora do mundo cósmico ("silêncio infinito").

A presença dos dois-pontos no verso 11 sintetiza a ideia de que assim como a sebe sugeriu a imaginação do infinito espacial, o sussurrar do vento desperta no poeta a ideia do infinito temporal, ou seja, da eternidade. E a voz do vento faz voltar à mente do poeta o passado e a época presente em suas manifestações reais, demonstrando a vida fugaz das gerações em relação à eternidade. Ao se escolher a palavra "suon", traduzida por "cantos" em português, parece não se querer representar somente a voz do vento, mas também o eco das ações dos homens, entrando em contraste com o silêncio presente no infinito.

No Zibaldone [1828], Leopardi discursa sobre a sensação agradável que o som desperta, associado à ideia de infinito:

"È piacevole qualunque suono (anche vilissimo) che largamente e vastamente si diffonda [...] A queste considerazioni appartiene il piacere che può dare e dà (quando non sia vinto dalla paura) il fragore del tuono, massime quand'è più sordo, quando è udito in aperta campagna; lo stormire del vento, massime nei detti casi quando freme confusamente in una foresta $[\ldots]^{109, "}(16$ Ottobre 1821$)$

109 “É agradável qualquer som (mesmo muito vil) que se disperse de forma ampla e vasta [...]. A essas considerações pertencem o prazer que pode dar, e dá, (quando não seja vencido pelo medo) o fragor do tom, sobretudo quando é mais surdo, quando é sentido em campo aberto; o sussurrar do vento, em especial nesses casos, quando freme de modo confuso numa floresta [...]." (16 de outubro de 1821) [Trad. Ana Thereza Basílio Vieira, in: LUCCHESI, 1996, p. 101) 
No último período do poema, o poeta entrega-se docemente a essa nova dimensão.

\section{E viva, e il suon di lei. Così tra questa}

Immensità s'annega il pensier mio:

$15 \mathrm{E}$ il naufragar m’è dolce in questo mare.
E viva com seus cantos. Assim, nessa

Imensidão se afoga o pensamento:

E doce é naufragar-me nesses mares.

Percebe-se que no fim do poema, o mundo que se faz mais próximo do poeta é o da imaginação, dada a presença da expressão "questa immensità", imensidão que simboliza aqui o infinito espacial e o infinito temporal. Essa inversão de distanciamento entre os dois mundos (real e ultrarreal), juntamente com a presença do verbo "s'annega", indicando o abandono da ciência ${ }^{110}$ do poeta, demonstra a total anulação do "eu" pensante diante da imensidão plasmada em sua mente.

Na tradução de Ivo Barroso, os demonstrativos "nessa/nesses" foram mantidos, assim como as imagens pertencentes ao mesmo campo semântico: "se afoga-naufragar-me-mares".

A presença dos dois pontos mais uma vez prepara o leitor para a mensagem final do poema: "E il naufragar m'è dolce in questo mare." - na imensidão do infinito a mente de forma serena perde-se; é graças a esse abandono de si mesmo que se pode encontrar o prazer e a felicidade negados ao homem no mundo real, assim como afirma Leopardi no Zibaldone, [51]: "il più solido piacere di questa vita è il piacere vano delle illusioni. ${ }^{111,}$

Nesse idílio, Leopardi faz uso da imaginação para subtrair-se da opressão do intelecto, com isso ele se aproxima da condição dos primitivos / da natureza. Ao criar imagens vagas, leves e indefinidas e ao naufragar em um mundo fora do tempo e do espaço, o poeta do Infinito se destaca da razão, satisfazendo assim seu desejo de prazer.

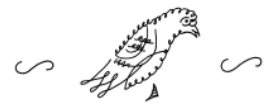

${ }^{110}$ Ciência no sentido de: conjunto de conhecimentos socialmente adquiridos ou produzidos, historicamente acumulados, dotados de universalidade e objetividade que permitem sua transmissão, e estruturados com métodos, teorias e linguagens próprias, que visam compreender e, poss., orientar a natureza e as atividades humanas. (Dicionário Aurélio Eletrônico - Século XXI - Versão 3.0 - Novembro de 1999)

111 "O mais sólido prazer desta vida é o prazer vão das ilusões." [51] - [Trad. nossa] 


\subsection{A REFLEXÃO PROFUNDA DE UM PASTOR}

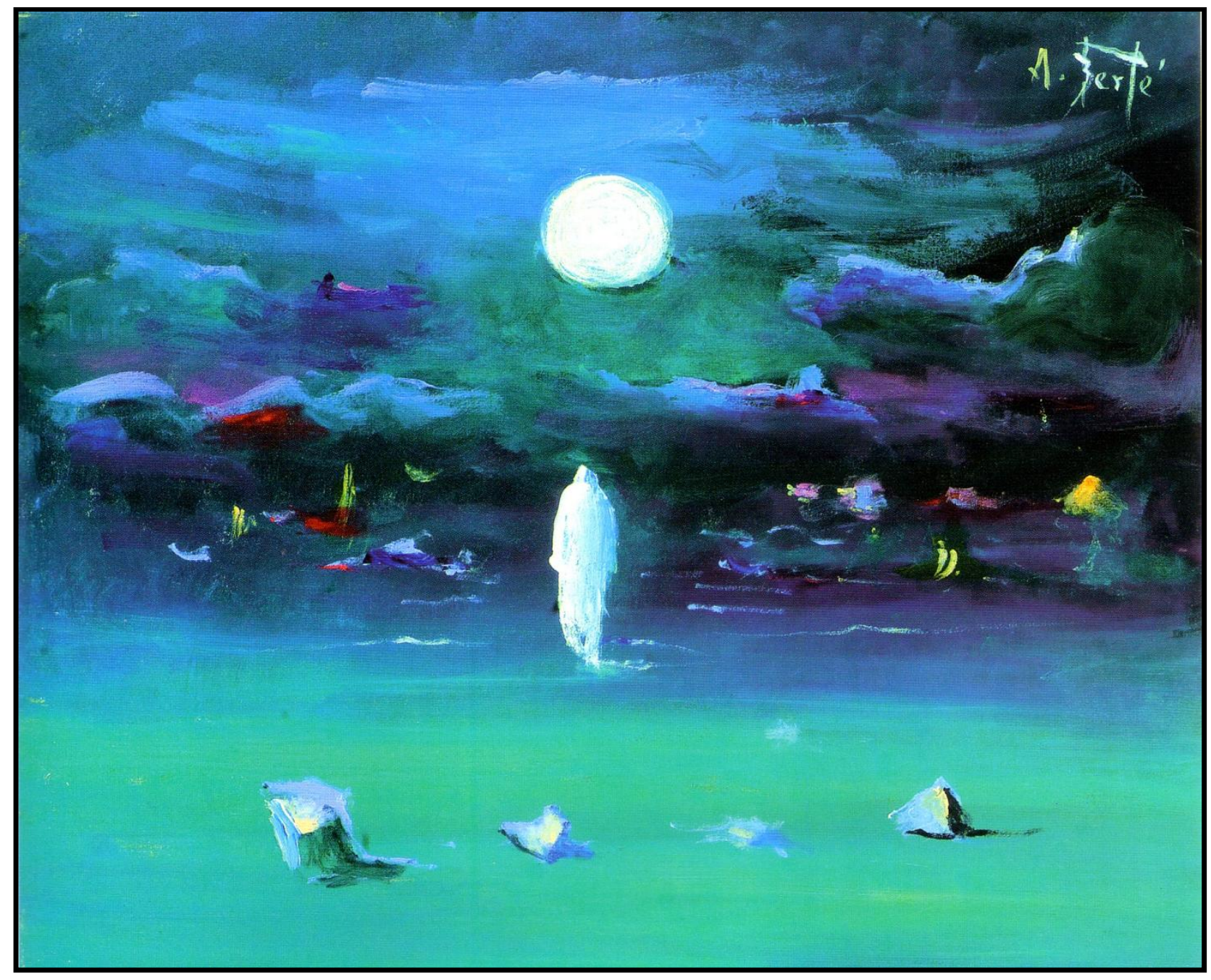

CANTO NOTTURNO DI UN PASTORE ERRANTE DELL'ASIA - Antonio Bertè 


\subsection{A REFLEXÃO PROFUNDA DE UM PASTOR: pessimismo cósmico}

É natural ao homem desejar a felicidade. Todavia, no mundo concreto em que está inserido, não existe a possibilidade de satisfazer seus desejos, já que são desejos infinitos de prazer, ou seja, não têm limites e nem duração, contrastando com o caráter limitado do mundo real. Ao perceber que os prazeres almejados são sempre superiores àqueles efetivamente alcançados, o homem sente-se cada vez mais desiludido diante de sua condição de infelicidade.

Inicialmente, Leopardi considerava o caráter da natureza como misericordioso, por sensibilizar-se com a condição humana. Por mais que a natureza não pudesse oferecer ao homem a completa satisfação de seus desejos infinitos, e, portanto, garantir-lhe a felicidade, ela criou as ilusões, doou-lhe a faculdade imaginativa, a fim de livrar-lo da consciência do real. Mas, se com o tempo, o homem fez cair o véu das ilusões, se foi perdendo a sua capacidade imagética, devido à sua sede de conhecimento, e com isso descobriu o que lhe deveria ser oculto, a culpa pelas dores sentidas seria do próprio homem.

Todavia, por volta de 1824, a concepção leopardiana de uma natureza benigna e providencial entra em crise. Em uma das Operette morali de Leopardi, mais precisamente no Dialogo della natura e di un islandese (escrito em maio de 1824), o homem, representado por um islandês, acusa a natureza:

tu sei nemica scoperta degli uomini, e degli altri animali, e di tutte le opere tue; che ora c'insidii ora ci minacci ora ci assalti ora ci puni ora ci percuoti ora ci laceri, e sempre o ci offendi o ci perseguiti; e che, per costume e per instituto, sei carnefice della tua propria famiglia, de' tuoi figliuoli e, per dir così, del tuo sangue e delle tue viscere ${ }^{112}$. (1995, p. 143)

Conforme a descrição acima, a natureza não é mais vista como mãe amorosa, pelo contrário, ela passa a ser um mecanismo cruel.

\footnotetext{
112 "tu és inimiga expressa dos homens, dos outros animais e de todas as tuas obras; que ora incides sobre nós, ora nos assaltas, nos espicaças, nos sacodes, nos dilaceras e sempre nos ofendes ou nos persegues, e que, por hábito ou por instituição, és carrasco da tua própria família, dos teus filhos e, por assim dizer, do teu sangue e das tuas vísceras [correção nossa].” [Trad. LUCCHESI; 1996, p. 361]
} 
Aos poucos, Leopardi muda suas concepções, direciona seus estudos para a verdade que tanto repudiou e odiou ${ }^{113}$. Ele reavalia a ideia que se fazia da natureza e da razão. Leopardi chega à conclusão de que se o homem sente constantemente um desejo de felicidade infinita, quem lhe impregnou a alma com essa necessidade foi a própria natureza e, consequentemente, condenou o homem e todas as criaturas do universo à perpétua infelicidade.

Em 1825, no Zibaldone [4128-4130], Leopardi evidencia o contraste existente entre os escopos da natureza geral e os da humanidade.

Il fine naturale dell'uomo e di ogni vivente, in ogni momento della sua esistenza sentita, non è nè può essere altro che la felicità, e quindi il piacere, suo proprio; e questo è anche il fine unico del vivente in quanto a tutta la somma della sua vita, azione, pensiero. [...] Dunque la natura, la esistenza non ha in niun modo per fine il piacere nè la felicità degli animali; piuttosto al contrario; ma ciò non toglie che ogni animale abbia $d i$ sua natura per necessario, perpetuo e solo suo fine il suo piacere, e la sua felicità, e così ciascuna specie presa insieme, e così la università dei viventi. Contraddizione evidente $\mathrm{e}$ innegabile nell'ordine delle cose e nel modo della esistenza, contraddizione spaventevole; ma non perciò men vera. [...] Anzi il fine della natura universale è la vita dell'universo, la quale consiste ugualmente in produzione conservazione e distruzione dei suoi componenti ${ }^{114}[\ldots] "$. (5-6 Aprile 1825)

Enquanto os homens têm como objetivo alcançar a felicidade, satisfazendo seus desejos, nota-se que, contrariamente, o escopo da natureza não é a felicidade das criaturas, mas a perpetuação da vida do universo, resultando em prejuízo dos seres vivos, que ela mesma cria, conserva e por fim destrói, com a intenção de manter o prosseguimento de um ciclo: tem-se aí o pessimismo cósmico leopardiano aflorando.

Percebe-se então que, neste momento, a verdadeira culpada pela infelicidade dos homens não é mais a razão, a qual destruía as ilusões dos homens, deixando livres os animais, mas sim a própria natureza. Por meio da razão, o homem torna-se consciente da própria situação de

\footnotetext{
${ }^{113}$ Carta ao amigo Pietro Giordani, 6 de maio de 1825.

114 "A finalidade natural do homem e de cada vivente, em cada momento da sua existência sentida, não é e nem pode ser outra coisa do que a felicidade, e, portanto, o seu prazer pessoal; e essa é também a finalidade única do vivente durante a soma de toda a sua vida, ação, pensamento. [...] Então, a natureza, a existência não tem de maneira alguma como finalidade o prazer nem a felicidade dos animais, se não o contrário; mas isso não exclui que cada animal tenha por sua natureza como necessário, perpétuo e único fim o seu prazer e a sua felicidade, e assim cada espécie colocada junto, e assim é a universalidade dos viventes. Contradição evidente e inegável na ordem das coisas e no mundo da existência, contradição assustadora; mas nem por isso menos verdadeira. [...] Pelo contrário, a finalidade da natureza universal é a vida do universo, a qual consiste igualmente em produção, conservação e destruição de seus componentes [...]" (5-6 de abril de 1825) - [Trad. nossa]
} 
desilusão, sofrimento, tédio e, portanto, de infelicidade, à qual não somente ele é condenado, mas as demais criaturas também, como se vê na seguinte passagem do Zibaldone [4175]:

"Non gli uomini solamente, ma il genere umano fu e sarà sempre infelice di necessità. Non il genere umano solamente ma tutti gli animali. Non gli animali soltanto ma tutti gli altri esseri al loro modo. Non gl'individui, ma la specie, i generi, i regni, i globi, i sistemi, i mondi ${ }^{115}$." (22 Aprile 1826)

Leopardi começa a considerar culpada de todas as coisas a natureza, absolvendo totalmente os homens. Para demonstrar o feroz mecanismo de destruição e de morte ao qual estão condenados todos os seres vivos, Leopardi, em uma passagem do Zibaldone, faz uma belíssima descrição de um jardim florido, onde aparentemente tudo parece estar em harmonia, mas que debaixo de sua aparência serena, tudo está em estado de sofrimento. Na descrição do jardim temse uma rosa ofendida pelo sol, um lírio sendo cruelmente chupado por uma abelha, em sua parte mais vital, uma árvore infestada de insetos, um ramo no chão quebrado pela força do vento, a grama sendo esmagada pelos passos de uma jovem sensível e gentil, que docemente arranca estelos, entre outras cenas. Toda essa descrição serve a demonstrar como frágeis criaturas são submissas à violência da natureza. Em suma: "tutta quella famiglia di vegetali è in stato di souffrance ${ }^{116,}$.

Quando o homem conscientiza-se de sua real situação na Terra, quando ele sente plenamente suas limitações e insignificância diante do universo, um sentimento se manifesta em sua alma e ali permanece: o tédio, sentimento esse abordado no poema Il canto notturno di un pastore errante dell'Asia, analisado a seguir.

\footnotetext{
115 "Não apenas os homens, mas o género humano foi e sempre será necessariamente infeliz. Não apenas o género humano, mas todos os animais. Não somente os animais, mas todos os seres a seu modo. Não os indivíduos, mas as espécies, os géneros, os reinos, os globos, os sistemas, os mundos." (22 de abril de 1826) - [Trad.nossa]

116 "Toda aquela família de vegetais é em estado de sofrimento" Zib. [4175-4177] - [Trad. nossa] - Souffrance: Leopardi escolhe manter o termo em francês quase que para sublinhar o forte significado que para ele tem o ato do sofrimento.
} 


\subsubsection{CANTO NOTTURNO DI UN PASTORE ERRANTE DELL'ASIA de Leopardi no Brasil}

\section{"Canto notturno di un pastore errante dell'Asia"}

\section{"Canto noturno de um pastor errante da Ásia"}

Che fai tu, luna, in ciel? dimmi, che fai, Silenziosa luna?

Sorgi la sera, e vai,

Contemplando i deserti; indi ti posi.

05Ancor non sei tu paga

Di riandare i sempiterni calli?

Ancor non prendi a schivo, ancor sei vaga

Di mirar queste valli?

Somiglia alla tua vita

10La vita del pastore.

Sorge in sul primo albore

Move la greggia oltre pel campo, e vede

Greggi, fontane ed erbe;

Poi stanco si riposa in su la sera:

15Altro mai non ispera.

Dimmi, o luna: a che vale

Al pastor la sua vita,

La vostra vita a voi? dimmi: ove tende

Questo vagar mio breve,

201 tuo corso immortale?

Vecchierel bianco, infermo,

Mezzo vestito e scalzo,

Con gravissimo fascio in su le spalle,

Per montagna e per valle,

25Per sassi acuti, ed alta rena, e fratte,

Al vento, alla tempesta, e quando avvampa

L'ora, e quando poi gela,

Corre via, corre, anela,

Varca torrenti e stagni,

30 Cade, risorge, e più e più s'affretta,

Senza posa o ristoro,

Lacero, sanguinoso; infin ch'arriva

Colà dove la via

E dove il tanto affaticar fu volto:

35Abisso orrido, immenso,

Ov'ei precipitando, il tutto obblia.

Vergine luna, tale

È la vita mortale.
Diz-me: o que fazes no céu, lua? o que, Silenciosa lua?

Enquanto a noite vê,

Contemplativa, os ermos, tu tramontas.

Correr essas estradas

Sempiternas ainda te compraz?

Será que não te cansas, não te enfadas

Destes vales jamais?

Semelha tua vida

A vida do pastor.

Surge ele ao primo albor;

Leva seu rebanho pelo campo e avista

Outros rebanhos, fontes e verduras;

De noite vai, cansado, repousar,

Mais não tem a esperar.

Diz-me, ó lua: afinal

De que lhe serve a vida?

A vossa vida a vós? diz-me: aonde vai

Ter meu breve vagar,

$\mathrm{O}$ teu curso imortal?

Velhinho branco, infirme,

Descalço e maltrapilho,

Um feixe pesadíssimo nas costas,

Por vales, por encostas,

Por funda areia, agudos seixos, brenhas,

Ao vento, à tempestade, e quando escalda

A hora, e depois gela,

Vai-se embora, corre, anela,

Vadeia rios e charcos.

Cai, levanta, e mais e mais se apressa,

Sem pouso nem descanso,

Rasgado, ensangüentado; e ei-lo que chega

Enfim aonde a via,

Aonde tanto afadigar conduz:

Abismo hórrido, imenso,

Em que ele se atirando a tudo esquece.

Pois, virgem lua, tal

È a vida mortal. 
Nasce l'uomo a fatica, 40Ed è rischio di morte il nascimento.

Prova pena e tormento

Per prima cosa; e in sul principio stesso

La madre e il genitore

Il prende a consolar dell'esser nato.

45Poi che crescendo viene,

L'uno e l'altro il sostiene, e via pur sempre

Con atti e con parole

Studiasi fargli core,

E consolarlo dell'umano stato:

50Altro ufficio più grato

Non si fa da parenti alla lor prole.

Ma perchè dare al sole,

Perchè reggere in vita

Chi poi di quella consolar convenga?

55 Se la vita è sventura,

Perchè da noi si dura?

Intatta luna, tale

È lo stato mortale.

Ma tu mortal non sei,

$60 \mathrm{E}$ forse del mio dir poco ti cale.

Pur tu, solinga, eterna peregrina,

Che sì pensosa sei, tu forse intendi,

Questo viver terreno,

Il patir nostro, il sospirar, che sia;

65Che sia questo morir, questo supremo

Scolorar del sembiante,

E perir dalla terra, e venir meno

Ad ogni usata, amante compagnia.

E tu certo comprendi

70Il perché delle cose, e vedi il frutto

Del mattin, della sera,

Del tacito, infinito andar del tempo.

Tu sai, tu certo, a qual suo dolce amore

Rida la primavera,

75A chi giova l'ardore, e che procacci

Il verno co' suoi ghiacci.

Mille cose sai tu, mille discopri,

Che son celate al semplice pastore.

Spesso quand'io ti miro

80Star così muta in sul deserto piano,

Che, in suo giro lontano, al ciel confina;

Ovver con la mia greggia

Seguirmi viaggiando a mano a mano;

E quando miro in cielo arder le stelle;
O homem nasce trabalhosamente, e é risco de morte o nascimento.

Prova pena e tormento

Em primeiro lugar; e no princípio

Já mãe e genitor

Começa a consolar de ter nascido.

Depois, quando crescido,

Uma e outro sustenta, e todavia,

Com atos e palavras,

Eles sempre o encorajam

E o consolam da humana condição;

A mais grata missão

Que sua prole os pais não fazem jus.

Mas por que dar à luz,

Por que manter em vida

Quem dela cumpre consolar depois?

Se a vida é desventura,

Por que a gente a atura?

Intacta lua, tal

É o estado mortal.

Mas talvez o que digo

Não te importe por seres imortal.

Mas tu, sozinha, eterna peregrina,

Que tão pensativa és, talvez entendas

Este viver terreno,

O sofrer nosso, o suspirar, que seja;

Que seja este morrer, este supremo

Descorar do semblante,

E da terra sumir, fugir do aceno

Da habitual, amante companhia,

E decerto compreendes

O segredo das coisas, vês o fruto

Da manhã e da noite,

Do tácito, infinito andar do tempo.

Sabes, por certo, a qual doce amor seu

Sorri a primavera,

A que, o estio é útil, a quem serve

$\mathrm{O}$ inverno e sua neve.

Mil coisas sabes tu, e mil descobres

Que estão ocultas ao pastor simplório.

Amiúde, ao te ver

Muda assim sobre campos que, desertos,

Lá na distância com o céu confinam;

Ou então a viajar

Comigo e meu rebanho tão de perto;

E quando olho a amplidão, de estrelas cheia, 
85Dico fra me pensando:

A che tale facelle?

Che fa l'aria infinita, e quel profondo

Infinito seren? che vuol dir questa

Solitudine immensa? ed io che sono?

90Così meco ragiono: e della stanza

Smisurata e superba,

E dell'innumerabile famiglia;

Poi di tanto adoprar, di tanti moti

D’ogni celeste, ogni terrena cosa,

95Girando senza posa,

Per tornare sempre là donde son mosse;

Uso alcun, alcun frutto

Indovinar non so. Ma tu per certo,

Giovinetta immortal, conosci il tutto.

100Questo io conosco e sento,

Che degli eterni giri,

Che dell'esser mio frale,

Qualche bene o contento

Avrà fors'altri; a me la vita è male.

$105 \mathrm{O}$ greggia mia che posi, oh te beata,

Che la miseria tua, credo, non sai!

Quanta invidia ti porto!

Non sol perchè d'affanno

Quasi libera vai;

110Ch'ogni stento, ogni danno,

Ogni estremo timor subito scordi;

Ma più perchè giammai tedio non provi.

Quando tu siedi all'ombra, sovra l'erbe,

Tu se' queta e contenta;

115E gran parte dell'anno

Senza noia consumi in quello stato.

Ed io pur seggo sovra l'erbe, all'ombra,

E un fastidio m'ingombra

La mente, ed uno spron quasi mi punge

120 Sì che, sedendo, più che mai son lunge

Da trovar pace o loco.

E pur nulla non bramo,

E non ho fino a qui cagion di pianto.

Quel che tu goda o quanto,

125Non so già dir; ma fortunata sei.

Ed io godo ancor poco,

O greggia mia, né di ciò sol mi lagno.

Se tu parlar sapessi, io chiederei:

Dimmi: perchè giacendo

130 A bell'agio, ozioso,
Penso e digo comigo:

Por que tanta candeia?

Por que estes ares infinitos, este

Infinito profundo, sereno, esta

Imensa solidão? E eu, que sou eu?

Assim penso comigo; e desta casa

Desmedida e soberba

E da sua família inumerável;

Pois de tanto ocupar-se, tantos giros

Das coisas, quer celestes, quer terrenas,

Que não conhecem trégua,

Mas voltam sempre ao ponto de partida;

Uso algum, fruto algum

Descobri-lhes consigo. Mas tu, certo,

Rapariga imortal, conheces tudo.

Eu só conheço e sinto

Que dos eternos giros,

Que do meu ser mortal

Quiçá bem ou prazer

Tenha alguém; para mim, a vida é mal.

O meu rebanho a descansar feliz,

Que não sabe, acho, da sua desventura!

Tenho-te tanta inveja?

Já quase liberado

De afãs ou de amargura

Vais, e minguas, cuidados

Excessivos temores pronto esqueces,

E, mais ainda, tédio não padeces.

Quando à sombra te sentas, sobre as ervas,

Ficas quieto e contente;

E grande parte do ano

Sem fastio tu a passas nesse estado.

Mas se me sento sobre a relva, à sombra,

Logo um tédio me ensombra

A mente, e um aguilhão vem-me pungir,

Ali posto, estou longe de sentir

Qualquer paz ou quietude.

E não cobiço nada,

Nem tenho até aqui razão de pranto.

$\mathrm{O}$ que gozas ou quanto

Não sei dizer; mas és afortunada.

Se gozo ainda pouco,

O rebanho meu, nem só disso me queixo.

Se soubesses falar, eu perguntava:

Diz-me: por que jazendo

A vontade, ocioso, 
S'appaga ogni animale;

Me, s'io giaccio in riposo, il tedio assale?

Forse s'avess'io l'ale

Da volar su le nubi,

135 E noverar le stelle ad una ad una

O come il tuono errar di giogo in giogo,

Più felice sarei, dolce mia greggia,

Più felice sarei, candida luna.

$O$ forse erra dal vero,

140 Mirando all'altrui sorte, il mio pensiero:

forse in qual forma, in quale

Stato che sia, dentro covile o cuna,

È funesto a chi nasce il dì natale.

\section{[Giacomo Leopardi]}

O anima! se embevece!

E em meu repouso o tédio me aparece?

Mas se asas eu tivesse

De voar sobre as nuvens,

Cada estrela contar que lá flutua,

Ou, qual trovão, errar de pico em pico,

Seria eu mais feliz, doce rebanho,

Seria eu mais feliz, cândida lua.

E talvez desatino

Este meu cogitar de outro destino:

Funéreo por igual,

Venha ele ao mundo em berço ou em cafua,

É, a quem nasce, o seu dia natal.

Conforme indicado pelo próprio poeta, o poema Canto notturno di un pastore errante dell'Asia foi composto entre 22 de outubro de 1829 e 9 de abril de 1830. Foi publicado pela primeira vez na edição florentina de 1831 com o título de Canto notturno di un pastore vagante dell'Asia, mas já na edição napolitana Starita (1835) tem-se a substituição de "vagante" por "errante".

Interessante é perceber que no autógrafo napolitano ${ }^{117}$ do poema em questão, entre o título e o poema, Leopardi introduz uma nota ${ }^{118}$. Nela, Leopardi transcreve parte de uma passagem lida em um artigo do Journal des Savants, em que um viajador russo, barão Meyendorff, descreve uma sua viagem feita da Rússia (Orenburgo) à Ásia Central (Bukhara) em 1820. Neste artigo, aquilo que mais chamou a atenção de Leopardi foi o costume de alguns pastores nômades da Ásia de passar a noite sentados sobre uma pedra a observar a lua, improvisando palavras tristes sob uma atmosfera igualmente mesta. Tal imagem sensibilizou muito o poeta, pois refletia aquilo que

\footnotetext{
117 http://www.bnnonline.it/biblvir/pas1rlr.htm ("Biblioteca Nazionale di Napoli" autografo on-line; acesso em 26/02/2010 às 20h)

118 "Plusieurs d'entre eux (parla di una delle nazioni erranti dell'Asia) passent la nuit assis sur une pierre à regarder la lune, et à improviser des paroles assez tristes sur des airs que ne le sont pas moins". Il barone di MEYENDORFF, Voyage d'Orembourg à Boukhara, fait en 1820, apresso il giornale des Savans, 1826, septembre, p. 518".

"Muitos deles (fala de uma das nações errantes da Ásia) passam à noite sentados sobre uma pedra a olhar a lua, e a improvisar palavras bem tristes sob ares não menos mestos". O barão de MEYENDORFF, Viagem de Orembourg a Boukhara, feito em 1820, no jornal des Savans, 1826, setembro, p. 518” [Trad. nossa]
} 
ele já vinha sentindo ao contemplar o céu, interrogando-se sobre a sorte terrena dos homens e sobre os porquês da vida.

Do ponto de vista formal, o poema é composto de seis estrofes de tamanhos diferentes [20 versos, 18 versos, 22 versos, 44 versos, 28 versos e 11 versos], dando um total de 143 versos, sendo eles hexassílabos e decassílabos, conforme a contagem métrica brasileira, livremente distribuídos.

Por se tratar de um longo monólogo entre um pastor solitário e o cosmo, representado pela lua, na vastidão da noite, prevalece no poema um ritmo lento e solene; o que faz lembrar o andamento de uma nênia.

Quanto ao esquema rímico, percebe-se que as estrofes têm um jogo livre de repetições sonoras, com algumas rimas alternadas e no meio do verso. Todavia, importante é assinalar que todas as seis estrofes apresentam uma rima final em "ale", bem como o primeiro verso da estrofe conclusiva, o que contribui com a interligação entre as estrofes.

A análise a seguir será feita em seis partes, conforme o número de estrofes do poema. Cada parte, por sua vez, será subdividida, seguindo um critério temático: vida humana e vida cósmica; homem e vida mortal; descrição pessimista da vida humana e indiferença da lua; o homem sem respostas aos seus porquês e a lua, força superior, conhecedora dos mistérios da vida; vida humana e vida animal; tudo é dor.

\section{Primeira estrofe: relação vida humana e vida cósmica}

Nessa primeira estrofe, um pastor faz uma série de indagações em relação à vida, ao seu significado e objetivo; para isso, dirige suas perguntas à lua, símbolo da transcendência. 
Che fai tu, luna, in ciel? dimmi, che fai, Silenziosa luna?

Sorgi la sera, e vai,

Contemplando i deserti; indi ti posi.

05Ancor non sei tu paga

Di riandare i sempiterni calli?

Ancor non prendi a schivo, ancor sei vaga

Di mirar queste valli?
Diz-me: o que fazes no céu, lua? o que, Silenciosa lua?

Enquanto a noite vê,

Contemplativa, os ermos, tu tramontas.

Correr essas estradas

Sempiternas ainda te compraz?

Será que não te cansas, não te enfadas

Destes vales jamais?

De forma pacata, porém demonstrando agitação da sua alma, um pastor, representando a voz do poeta, dirige-se diretamente à lua. As perguntas que ele faz não são retóricas, tampouco servem como meio de instaurar um diálogo romântico com a lua; por mais que as perguntas sejam carregadas de apreensão e de estupor diante do mistério cósmico, não são angustiantes ${ }^{119}$.

Nos primeiros versos, já é possível perceber que o pastor sente a necessidade de obter respostas aos seus porquês, devido a uma série de recursos criados: a repetição do sintagma "che fai" na abertura do primeiro verso, repetido no seu final; na forte presença de vocativos "luna" "silenziosa luna", reforçados pelo pronome "tu"; além da presença do exortativo "dimmi".

Por mais que o pastor queira obter respostas, sabe-se que a sua interlocutora não lhe fornecerá alguma, devido à expressão "silenziosa luna” presente no segundo verso. O silêncio não é só o da lua, ele se propaga na paisagem noturna, já que o deslocamento do adjetivo diante do substantivo sugere a ampliação do silêncio.

Surge a lua ao anoitecer e inicia, assim, o seu eterno caminhar. Lá do alto ela contempla os desertos, vistos não somente como o deserto em que está localizado o pastor errante (planícies da Ásia central), como também toda a extensão terrestre, já que a visão lunar da Terra parece ser um ambiente desértico, devido à distância entre elas. Até que, após percorrer as vias do céu, a lua tramonta. Interessante é perceber que o período se abre com o verbo "Sorgi" - v.3 e se conclui com o verbo "posi" - v.4, colocados cuidadosamente em polos opostos, pois um indica o surgir da lua no céu e o outro o seu desaparecer.

\footnotetext{
${ }^{119}$ Para Giulio Ferroni, "a voz do eu poético leopardiano assumiu o tom da voz mesta e doce do pastor e, acusações e tons agressivos foram substituídos por perguntas mais submissas, mas nem por isso elas são menos firmes e insistentes, com uma força demonstrativa peremptória e incontestável." (2003: 574) - [Trad. nossa]
} 
O mesmo não acontece nos versos equivalentes traduzidos, já que o período em questão não apresenta o surgir da lua, tampouco o seu caminhar, dando a impressão de que, no momento em que a lua tramonta, quem observa os ermos (desertos) é a noite e não mais a lua, já que o verbo "vê" está na terceira pessoa e a lua é representada pelo tu - "tu tramontas".

Continua a sequência de indagações. No início o pastor pergunta o que faz a lua no céu, qual é o escopo de sua presença? Será que ela já não está saciada do seu contínuo percorrer as eternas e sempre iguais vias do céu, será que ela já não se enfastiou, ou ainda está desejosa, de admirar do alto estas intermináveis planícies?

Somiglia alla tua vita 10La vita del pastore.

Sorge in sul primo albore

Move la greggia oltre pel campo, e vede

Greggi, fontane ed erbe;

Poi stanco si riposa in su la sera:

15Altro mai non ispera.

Dimmi, o luna: a che vale

Al pastor la sua vita,

La vostra vita a voi? dimmi: ove tende

Questo vagar mio breve, 20Il tuo corso immortale?
Semelha tua vida

A vida do pastor.

Surge ele ao primo albor;

Leva seu rebanho pelo campo e avista

Outros rebanhos, fontes e verduras;

De noite vai, cansado, repousar,

Mais não tem a esperar.

Diz-me, ó lua: afinal

De que lhe serve a vida?

A vossa vida a vós? diz-me: aonde vai

Ter meu breve vagar,

O teu curso imortal?

No período central da estrofe (v.9 e 10), o pastor errante afirma existir semelhança entre a vida da lua e a vida do pastor (representada por ele mesmo). Para confirmar a afirmação feita, tem-se, nos versos seguintes, uma descrição dos atos do pastor. Percebe-se a existência de um paralelismo em relação ao movimento lunar apresentado no início da estrofe e a rotina quotidiana do pastor, devido principalmente às correspondências verbais: o pastor desperta - "sorge" (a lua - tu sorgi) - assim que rompe a aurora; conduz sempre em frente - "move...oltre" (a lua - vai) o seu rebanho pelo campo; vê - "vede" (a lua - contemplando) - rebanhos, fontes e relvas; para, enfim, cansado, repousar - "si riposa" (a lua - ti posi) - de noite. Toda essa descrição é marcada por um tom de tristeza que reforça a monotonia da longa e pesada rotina do pastor. 
Para encerrar o período, e assim a rotina da vida do pastor, seguido de dois pontos, tem-se o verso: "Altro mai non ispera", o qual apresenta uma tríplice negação, reforçando a inexistência de uma mudança em relação às condições existências do pastor.

$\mathrm{Na}$ tradução brasileira, a sequência verbal (surge - leva - avista - vai repousar) foi devidamente considerada, todavia, como já visto anteriormente, não consta a mesma sequência verbal na descrição que se refere à vida lunar, logo, não se tem o jogo entre o paralelismo descritivo das vidas da lua e do homem.

No último período que encerra a primeira estrofe, o pastor sente a necessidade de saber qual é a serventia da própria vida, bem como da vida dos astros para eles mesmos, uma vez que ambas as vidas se assemelham. Mas em seguida, ao se questionar para onde levará o breve e temporâneo vagar do pastor sobre a terra e, o longo e imortal correr da lua, o pastor identifica contrastes entre a vida humana e a celestial: a passagem do homem na Terra é breve além de ser somente um vagar, vagar sem um objetivo, enquanto que a existência da lua é eterna, mas que segue um curso, portanto, existe um objetivo nesse seu vagar, que porém não é conhecido.

\section{Segunda estrofe: homem e vida mortal}

A segunda estrofe do poema é formada de dois períodos. O primeiro, composto de 16 versos, é dedicado à imagem de um velhinho e à corrida que marca a história de sua vida. $\mathrm{O}$ segundo período, composto de 2 versos, afirma ser a vida desse velhinho a representação da vida mortal de toda a espécie humana.

Vecchierel bianco, infermo, Mezzo vestito e scalzo, Con gravissimo fascio in su le spalle, Per montagna e per valle, 25Per sassi acuti, ed alta rena, e fratte, Al vento, alla tempesta, e quando avvampa L'ora, e quando poi gela, Corre via, corre, anela, Varca torrenti e stagni, 30 Cade, risorge, e più e più s'affretta, Senza posa o ristoro,
Velhinho branco, infirme, Descalço e maltrapilho, Um feixe pesadíssimo nas costas, Por vales, por encostas, Por funda areia, agudos seixos, brenhas, Ao vento, à tempestade, e quando escalda A hora, e depois gela, Vai-se embora, corre, anela, Vadeia rios e charcos. Cai, levanta, e mais e mais se apressa, Sem pouso nem descanso, 
Lacero, sanguinoso; infin ch'arriva

Colà dove la via

E dove il tanto affaticar fu volto:

35Abisso orrido, immenso,

Ov'ei precipitando, il tutto obblia.

Vergine luna, tale

È la vita mortale.
Rasgado, ensangüentado; e ei-lo que chega

Enfim aonde a via,

Aonde tanto afadigar conduz:

Abismo hórrido, imenso,

Em que ele se atirando a tudo esquece.

Pois, virgem lua, tal

È a vida mortal.

Diferentemente da primeira estrofe, marcada por um ritmo solene e pela amplitude das imagens, o período que abre a segunda estrofe tem um ritmo bem mais nervoso, graças à longa sequência nominal que vai descrevendo o velhinho e à rápida sucessão verbal que marca as condições de viagem pelas quais ele passa, tudo isso regido por um único sujeito: "vecchierel", posto logo no início do período. Tais recursos foram bem mantidos na tradução brasileira.

A vida desse velhinho, pálido e encanecido, é comparada a uma corrida fatigante, feita sob as mais adversas condições climáticas, as quais o tornam débil e maltrapilho. Ele segue, ofegante, sem parar, carregando em suas costas um fardo pesado, símbolo da própria vida, até que chega ao lugar destinado, meta de sua vida: um abismo hórrido e imenso, mas que, no fim das contas, tem o poder de tudo cancelar, fazendo-o esquecer o mal da vida.

No fim da estrofe, o pastor direciona-se novamente à virgem lua, que incólume contempla as vivendas humanas. Toda a descrição feita no primeiro período serve para exemplificar a vida de todos os humanos, a qual é marcada por inúmeras dificuldades e sofrimentos, terminando inevitavelmente com a morte, a qual cancela para sempre toda a memória humana ${ }^{120}$.

\footnotetext{
${ }^{120}$ Alguns anos antes, no Zibaldone [4162-3] Leopardi já dizia: "Che cosa è la vita? Il viaggio di un zoppo e infermo che con un gravissimo carico in sul dosso per montagne ertissime e luoghi sommamente aspri, faticosi e difficili, alla neve, al gelo, alla pioggia, al vento, all'ardore del sole, cammina senza mai riposarsi dì e notte uno spazio di molte giornate per arrivare a un cotal precipizio o un fosso, e quivi inevitabilmente cadere. (Bologna, 17 Gennaio 1826) "O que é a vida? A viagem de um manco e enfermo que com uma pesadíssima carga no seu dorso por montanhas muito íngremes e lugares sumamente ásperos, fatigantes e difíceis, na neve, no gelo, na chuva, no vento, no ardor do sol, anda sem nunca repousar dia e noite um espaço de muitas jornadas para chegar num precipício ou numa fossa, e então inevitavelmente cair." (17 de janeiro de 1826) - [Trad. nossa]
} 


\section{Terceira estrofe: descrição pessimista da vida humana e indiferença da lua}

A atenção aqui é novamente direcionada à existência humana, em especial no momento em que nasce o homem.

Nasce l'uomo a fatica, 40Ed è rischio di morte il nascimento.

Prova pena e tormento

Per prima cosa; e in sul principio stesso

La madre e il genitore

Il prende a consolar dell'esser nato.

45Poi che crescendo viene,

L'uno e l'altro il sostiene, e via pur sempre

Con atti e con parole

Studiasi fargli core,

E consolarlo dell'umano stato:

50Altro ufficio più grato

Non si fa da parenti alla lor prole.
O homem nasce trabalhosamente, e é risco de morte o nascimento.

Prova pena e tormento

Em primeiro lugar; e no princípio

Já mãe e genitor

Começa a consolar de ter nascido.

Depois, quando crescido,

Uma e outro sustenta, e todavia,

Com atos e palavras,

Eles sempre o encorajam

E o consolam da humana condição;

A mais grata missão

Que sua prole os pais não fazem jus.

A vida do homem, já no momento de seu nascimento, é marcada pela dor, pois ele corre o maior risco de sua vida: ele pode morrer ao nascer.

$\mathrm{Na}$ época em que Leopardi viveu, a taxa de mortalidade perinatal atingia níveis elevadíssimos. Em 1819, ele escreveu no Zibaldone [68-9]:

\footnotetext{
"Il nascere istesso dell'uomo cioè il cominciamento della sua vita, è un pericolo della vita, come apparisce dal gran numero di coloro per cui la nascita è cagione di morte, non reggendo al travaglio e ai disagi che il bambino prova nel nascere. E nota ch'io credo che esaminando si troverà che fra le bestie un molto minor numero proporzionatamente perisce in questo pericolo, colpa probabilmente della natura umana guasta e indebolita dall'incivilimento ${ }^{121}$.
}

O choro da criança, por mais que seja natural e instintivo, vem interpretado de forma pessimista pelo poeta. Para ele, a primeira manifestação de vida da criança - o choro - é carregada de sentimentos negativos: pena e tormento. Pelo mesmo viés, é interpretado o

\footnotetext{
121 “O próprio nascer do homem, ou seja, o início de sua vida, é um perigo da vida, como mostra o grande número de pessoas que o nascimento é causa de morte, não aguentando o trabalho (tormento) e os desconfortos que a criança sente ao nascer. E eu acredito que examinando encontrar-se-á entre os animais um número muito menor proporcionadamente de perecimento neste perigo, culpa provavelmente da natureza humana gasta e enfraquecida pela civilização". [Trad. nossa]
} 
comportamento dos pais ao consolar a criança recém-nascida, consolo que serve para remediar a culpa que eles sentem por tê-la trazida a um mundo infeliz.

Ao longo de todo o crescimento da criança, os pais continuamente a ajudam por meio de atos e de palavras, esforçam-se em encorajá-la e a consolam pelo fato de ter nascido.

Percebe-se que nos versos 45 e 46 tem-se expressões ("crescendo viene" e "pur sempre") que sugerem a continuidade da ação, o acompanhamento constante dos pais durante o desenvolver dos filhos. Outra expressão marcante no período é a do verso 47 "studiasi fargli core" que parece demonstrar, em sentido pessimista, o esforço da parte dos pais em incentivar coragem aos filhos para continuarem a vida. No poema traduzido, os versos equivalentes não recriam os efeitos do original, já que a expressão "quando crescido" não sugere o crescimento em processo, bem como o esforço feito pelos pais não é acentuado.

Os últimos dois versos (vv. 50-51), que concluem o segundo período, sintetizam o raciocínio do poeta em relação à tarefa dos pais: não há tarefa mais grata do que essa de consolar os filhos $^{122}$. A mesma mensagem não é tão clara nos versos traduzidos por José Paulo Paes, pois parece sugerir, de forma contorcida, que os pais não fazem jus a mais grata missão.

${ }^{122}$ Leopardi no Zibaldone [2607] reporta essa mesma idéia: "Così tosto come il bambino è nato, convien che la madre che in quel punto lo mette al mondo, lo consoli, accheti il suo pianto, e gli alleggerisca il peso di quell'esistenza che gli dà. E l'uno de' principali uffizi de' buoni genitori nella fanciullezza e nella prima gioventù de' loro figliuoli, si è quello di consolarli, d'incoraggiarli alla vita; perciocchè i dolori e i mali e le passioni riescono in quell'età molto più gravi, che non a quelli che per lunga esperienza, o solamente per esser più lungo tempo vissuti, sono assuefatti a patire. $\mathrm{E}$ in verità conviene che il buon padre e la buona madre studiandosi di racconsolare i loro figliuoli, emendino alla meglio, ed alleggeriscano il danno che loro hanno fatto col procrearli. Per Dio! perchè dunque nasce l'uomo? e perchè genera? per poi racconsolar quelli che ha generati del medesimo essere stati generati?" (13 Agosto 1822)

"Assim que a criança nasceu, convém que a mãe, que naquele momento o colocou no mundo, o console, aquiete o seu choro, e lhe alivie o peso daquela existência que lhe dá. E uma das principais tarefas dos bons pais na infância e na primeira juventude de seus filhinhos, é aquela de consolar-los, de encorajá-los à vida; porque as dores e os males e as paixões são naquela idade muito mais graves, do que naqueles com longa experiência, ou somente por terem vivido mais a longo, são mais acostumados a sofrer. E na verdade convém que o bom pai e a boa mãe esforçando-se de aconselhar os filhinhos, remedeiem do melhor modo, e aliviem os danos que eles fizeram ao procriá-los. Por Deus! Por que então nasce o homem? E por que gera? Para depois consolar aqueles que ele gerou pelo fato de terem sido gerados?" (13 de Agosto de 1822) - [Trad. nossa] 
Ma perchè dare al sole,

Perchè reggere in vita

Chi poi di quella consolar convenga?

55Se la vita è sventura,

Perchè da noi si dura?

Intatta luna, tale

È lo stato mortale.

Ma tu mortal non sei, ${ }_{60} \mathrm{E}$ forse del mio dir poco ti cale.
Mas por que dar à luz, Por que manter em vida Quem dela cumpre consolar depois?

Se a vida é desventura, Por que a gente a atura?

Intacta lua, tal É o estado mortal.

Mas talvez o que digo

Não te importe por seres imortal.

Mas se assim é, logo surgem novas perguntas carregadas de pessimismo: qual é o sentido de se continuar a por no mundo crianças que terão de ser consoladas por terem nascido? Se a vida é só dor e sofrimento, por que persistimos em vivê-la, suportando-a?

No fechamento da estrofe, assim como visto nos últimos versos da estrofe precedente, novamente o pastor direciona-se à intacta lua, intacta no mesmo sentido de virgem, incólume das misérias humanas. O pastor lhe mostra a condição do estado mortal, mas por mais que ele tenha se identificado com a lua, como já analisado logo no início do poema, lhe vem em mente que ele é um mortal, condição diferente da sua imortal interlocutora, sendo ela imortal. Devido a tal diferença o pastor acredita que talvez pouco importe à lua as preocupações e as angústias dos homens.

A presença das rimas nos versos de 55 a 58 (sventura - dura / tale - mortale), ajudam a criar um efeito de musicalidade no poema, além de serem significativas, pois a primeira dupla de rimas aponta para a característica duradoura da desventura na vida humana; enquanto que a segunda sintetiza o estado mortal. Os mesmos efeitos rímicos foram mantidos nos versos traduzidos, mas na primeira dupla de rimas (desventura - atura) a atenção é dirigida não mais à duração da desventura, e sim à suportabilidade da parte do homem. 


\section{Quarta estrofe: o homem sem respostas aos seus porquês e a lua, força superior, conhecedora dos mistérios da vida}

Ao conscientizar-se da própria impossibilidade de conseguir responder aos porquês das coisas, o pastor acredita que a lua, por ser imortal, tenha as explicações e seja conhecedora do sentido do mundo e da utilidade da vida para o homem.

Pur tu, solinga, eterna peregrina,

Che sì pensosa sei, tu forse intendi,

Questo viver terreno,

Il patir nostro, il sospirar, che sia;

65Che sia questo morir, questo supremo

Scolorar del sembiante,

E perir dalla terra, e venir meno

Ad ogni usata, amante compagnia.

E tu certo comprendi

70Il perché delle cose, e vedi il frutto

Del mattin, della sera,

Del tacito, infinito andar del tempo.

Tu sai, tu certo, a qual suo dolce amore

Rida la primavera,

75A chi giova l'ardore, e che procacci

Il verno co' suoi ghiacci.

Mille cose sai tu, mille discopri,

Che son celate al semplice pastore.
Mas tu, sozinha, eterna peregrina, Que tão pensativa és, talvez entendas

Este viver terreno,

O sofrer nosso, o suspirar, que seja;

Que seja este morrer, este supremo

Descorar do semblante,

E da terra sumir, fugir do aceno

Da habitual, amante companhia,

E decerto compreendes

O segredo das coisas, vês o fruto

Da manhã e da noite,

Do tácito, infinito andar do tempo.

Sabes, por certo, a qual doce amor seu

Sorri a primavera,

A que, o estio é útil, a quem serve

$\mathrm{O}$ inverno e sua neve.

Mil coisas sabes tu, e mil descobres

Que estão ocultas ao pastor simplório.

Mesmo se aparentemente a lua não se interessa pela condição humana, conforme visto no último verso da estrofe precedente, para o pastor, a lua, solitária e eterna viajante dos céus, com sua aparência tão pensativa, talvez entenda o significado da vida, das dores e dos suspiros humanos; e principalmente da morte, vista por meio de três momentos precisos: destaque físico com o improviso descorar do semblante; destaque da terra e da natureza - com o desaparecimento da terra; e o destaque dos entes queridos - com o abandonar das pessoas amadas que por tanto tempo fizeram companhia ao homem e tornaram sua vida mais suportável.

Interessante é a tríplice presença dos demonstrativos (questo) nos versos 63 (Questo viver terreno) e 65 (Che sia questo morir, questo supremo / scolorar del sembiante,). Percebe-se que eles se referem à vivência terrestre e visto que o pastor, ser mortal, está se dirigindo à lua, eles 
servem a demonstrar a distância existente entre a vida do pastor e a lua, recurso que é mantido na tradução brasileira.

A partir do verso 69, o pastor não faz mais suas afirmações sob forma de termos dubitativos, ( $t$ u forse intendi - v.62), ele agora se convence de que certamente a lua compreende aquilo que ele não sabe ( $E$ tu certo comprendi), principalmente porque agora ele não se refere mais às coisas pequenas que dizem respeito ao homem e que, portanto, possam ser indiferentes à lua; neste momento ele tratará do moto de todas as coisas, ou seja, do infinito universo do qual a lua faz parte.

Para o pastor a lua sabe o porquê das coisas, ela conhece o significado do dia, da noite e do tácito e infinito andar do tempo; decerto sabe a qual doce amor sorri a primavera, a quem é útil o ardor do verão e o gelo do inverno. Belíssimo é o verso 72 em que se recria harmoniosamente o fluir do tempo; bem como os versos 73 e 74 em que ele, com poucas palavras, personifica a primavera, como se ela tivesse a alma de uma garota apaixonada que se embeleza para agradar ao rapaz que ama.

Comparada à ignorância do pastor, a lua conhece mil coisas e irá conhecer outras mais.

Spesso quand'io ti miro

80Star così muta in sul deserto piano,

Che, in suo giro lontano, al ciel confina;

Ovver con la mia greggia

Seguirmi viaggiando a mano a mano;

E quando miro in cielo arder le stelle;

85Dico fra me pensando:

A che tale facelle?

Che fa l'aria infinita, e quel profondo

Infinito seren? che vuol dir questa

Solitudine immensa? ed io che sono?

90Così meco ragiono: e della stanza

Smisurata e superba,

E dell'innumerabile famiglia;

Poi di tanto adoprar, di tanti moti

D’ogni celeste, ogni terrena cosa,

95Girando senza posa,

Per tornare sempre là donde son mosse;

Uso alcun, alcun frutto

Indovinar non so. Ma tu per certo
Amiúde, ao te ver

Muda assim sobre campos que, desertos,

Lá na distância com o céu confinam;

Ou então a viajar

Comigo e meu rebanho tão de perto;

E quando olho a amplidão, de estrelas cheia, Penso e digo comigo:

Por que tanta candeia?

Por que estes ares infinitos, este

Infinito profundo, sereno, esta

Imensa solidão? E eu, que sou eu?

Assim penso comigo; e desta casa

Desmedida e soberba

E da sua família inumerável;

Pois de tanto ocupar-se, tantos giros

Das coisas, quer celestes, quer terrenas,

Que não conhecem trégua,

Mas voltam sempre ao ponto de partida;

Uso algum, fruto algum,

Descobri-lhes consigo. Mas tu, certo, 
Sempre quando o pastor começa a contemplar a imensidão do espaço em que a lua está inserida, ou quando ele a observa seguindo-o juntamente com seu rebanho durante suas longas viagens, ou quando ele olha no céu o brilhar das estrelas, se pergunta: por qual motivo brilham no céu tantas luzes? Qual é o encargo desse espaço sem fim e desse céu infinito? O que quer dizer essa imensidão do universo em que o homem está inserido, sozinho e perdido? E eu, o que sou?

Tais indagações continuam sem respostas, pois a lua, vista como uma força transcendental - já que o seu conhecimento ultrapassa a capacidade que o homem tem - segue seu caminho muda, demonstrando a sua impassibilidade diante da necessidade de entender do homem.

O tom das perguntas do pastor se faz nessa estrofe mais pacato, tanto porque ele se sente dominado diante de tamanho silêncio e imensidão, quanto por estar concentrado em temas insolúveis, que vão além da compreensão humana.

Diante do silêncio lunar, o pastor expõe o modo como ele pensa, declarando a sua impotência diante do mistério das coisas, já que ele não consegue encontrar nenhuma utilidade, nenhuma razão para a existência do universo, tão vasto, tão grandioso, para a inumerável quantidade de seres que habitam nele, nem mesmo para tamanho atarefamento e locomoção das coisas do céu e da terra que percorrendo sem trégua, retornam sempre ao local de origem.

Todo esse longo pensar do pastor é exposto em um único período composto de nove versos. Para demonstrar o atordoamento do pastor diante de um círculo infinito de seres, de coisas, de tempo e de espaço, todo o período tem uma construção fatigante, pois uma forte sequência de complementos antecede o verbo que a rege, posto no fim do período (Indovinar non so); assim como a escolha de expressões, como "smisurata, innumerabile, tanti moti; ogni cosa; senza posa" ajudam a criar um efeito rítmico mais veloz aos versos. Recursos também bem mantidos por José Paulo Paes em sua tradução. 
Indovinar non so. Ma tu per certo,

Giovinetta immortal, conosci il tutto.

100Questo io conosco e sento,

Che degli eterni giri,

Che dell'esser mio frale,

Qualche bene o contento

Avrà fors'altri; a me la vita è male.
Descobri-lhes consigo. Mas tu, certo,

Rapariga imortal, conheces tudo.

$\mathrm{Eu}$ só conheço e sinto

Que dos eternos giros,

Que do meu ser mortal

Quiçá bem ou prazer

Tenha alguém; para mim, a vida é mal.

O pastor volta a afirmar que a lua, por ser imortal, é conhecedora do mistério do universo. A única verdade que o homem mortal conhece, herdada de sua secular experiência, é a ideia de que o perpétuo movimento rotativo dos astros e a sua frágil existência talvez sejam proveitosos e úteis a alguém, mas a sua conclusão irrevogável é de que, para ele, a vida é uma condição de dor.

A lua, ao longo do poema, ganha cada vez mais características humanas. Por mais que ela não responda às indagações do pastor, não é vista por ele de modo negativo, já que a chama de forma afetuosa com o diminutivo "giovinetta" no verso 99. Na tradução de José Paulo Paes, temse a substituição de "giovinetta" por "rapariga", mas tal escolha não parece ser a mais oportuna, pois a expressão "rapariga", com o sentido de jovenzinha é de pouco uso hoje no Brasil, sendo mais um lusitanismo. Ao contrário, a mesma expressão no Brasil, pode ser interpretada em sentido pejorativo $^{123}$, o qual certamente em contradição ao do poema leopardiano.

\section{Quinta estrofe: vida humana e vida animal}

Assim como a lua é testemunha da vida levada pelo pastor, também o é o seu rebanho, mas com uma diferença, o último não está distante do pastor, ele está no mesmo plano, em contato com a terra; por isso a atenção do pastor é direcionada ao rebanho nesta quinta estrofe.

1050 greggia mia che posi, oh te beata,

Che la miseria tua, credo, non sai!

Quanta invidia ti porto!

Non sol perchè d'affanno

Quasi libera vai;

110Ch'ogni stento, ogni danno,
O meu rebanho a descansar feliz, Que não sabe, acho, da sua desventura! Tenho-te tanta inveja?

Já quase liberado

De afãs ou de amargura

Vais, e minguas, cuidados

${ }^{123}$ Dicionário Aurélio Eletrônico - Século XXI - Versão 3.0 - Novembro de 1999. (rapariga: Bras. N. N.E. MG GO Amante ou concubina / Meretriz.) 
Ogni estremo timor subito scordi;

Excessivos temores pronto esqueces,

Ma più perchè giammai tedio non provi.

E, mais ainda, tédio não padeces.

Quando tu siedi all'ombra, sovra l'erbe, Quando à sombra te sentas, sobre as ervas,

Tu se' queta e contenta;

115 E gran parte dell'anno

Ficas quieto e contente;

Senza noia consumi in quello stato.

E grande parte do ano

Sem fastio tu a passas nesse estado.

Conforme declarado pelo pastor no encerramento da quarta estrofe, a vida para o homem é uma condição de dor. Para explicar o porquê de tal conclusão ele contrapõe a sua vida e condição àquela dos animais, mais precisamente, de seu rebanho.

Nesta primeira parte da quinta estrofe, o pastor aprecia o repouso de seu rebanho. Para ele os animais são felizardos, pois acredita não terem consciência de nada, logo ignoram a condição de infelicidade a que todos os mortais são condenados.

O pastor inveja os animais, simbolizados pelo seu rebanho, não somente porque eles quase não sentem sofrimento na vida (dificuldades, perdas, medos extremos), já que tão logo o esquecem, mas principalmente por eles nunca sentirem tédio.

Ao observar o repouso do seu rebanho, o pastor nota que quando os animais descansam debaixo de uma sombra, sobre a grama, eles têm um ar sereno e contente, passando boa parte de suas vidas assim, sem demonstrar sofrimento.

Percebe-se que para o pastor, beato é aquele mortal que ignora a sua condição de infelicidade, como é o caso dos animais. Todavia, tal pensamento ainda está em via de formulação, já que no momento em que ele o expõe faz uso de algumas expressões dubitativas, como nos versos 106 (Che la miséria tua, credo, non sai! - grifo nosso) e 109 (Quasi libera vai; - grifo nosso).

Ao longo do poema, o pastor dirige-se ao seu rebanho no feminino "greggia" no lugar de "gregge", gênero masculino. Assim como visto com a sua primeira interlocutora, a lua, quando utiliza um diminutivo afetivo "giovinetta", o pastor ao feminizar o seu segundo interlocutor, o rebanho, cria um efeito atenuado, instaurando uma relação gentil e afetuosa com ele também. $\mathrm{O}$ 
mesmo efeito não foi criado na tradução brasileira. José Paulo Paes escolheu manter o substantivo "rebanho" (masculino), talvez porque em português, o substantivo feminino "malhada" não aludiria naturalmente ao rebanho de ovelhas para o leitor.

Ed io pur seggo sovra l'erbe, all'ombra, E un fastidio m'ingombra

La mente, ed uno spron quasi mi punge 120 Sì che, sedendo, più che mai son lunge

Da trovar pace o loco.

E pur nulla non bramo,

E non ho fino a qui cagion di pianto.

Quel che tu goda o quanto, 125Non so già dir; ma fortunata sei.

Ed io godo ancor poco,

O greggia mia, né di ciò sol mi lagno.

Se tu parlar sapessi, io chiederei:

Dimmi: perchè giacendo

130 A bell'agio, ozioso,

S'appaga ogni animale;

$\mathrm{Me}$, s'io giaccio in riposo, il tedio assale?
Mas se me sento sobre a relva, à sombra, Logo um tédio me ensombra A mente, e um aguilhão vem-me pungir, Ali posto, estou longe de sentir Qualquer paz ou quietude.

E não cobiço nada,

Nem tenho até aqui razão de pranto.

O que gozas ou quanto

Não sei dizer; mas és afortunada.

Se gozo ainda pouco,

O rebanho meu, nem só disso me queixo.

Se soubesses falar, eu perguntava:

Diz-me: por que jazendo

A vontade, ocioso,

O anima! se embevece!

E em meu repouso o tédio me aparece?

Contrapondo-se ao seu rebanho, o pastor explica que por mais que ele também faça as mesmas coisas: deitar-se sobre a grama, debaixo de uma sombra, aquilo que o diferencia dos animais é o fato de se sentir dominado pelo tédio, de sentir a necessidade de saber o porquê da vida. Portanto, mesmo ele estando ali repousando, como os animais, ele está bem longe de sentir paz e serenidade.

Para marcar a contradição existente entre as duas condições (rebanho e pastor), tem-se a construção de dois períodos contrapostos entre si, demonstrando isso já no início dos períodos com o uso de um recurso, o quiasmo, entre os versos 113 “Quando tu siedi all'ombra, sovra l'erbe" e 117 “Ed io pur seggo sovra l'erbe, all'ombra,".

A contraposição instaurada seria, então, entre os animais - seres não dotados de razão, e, portanto, não atormentados pela sede de conhecimento, tornando-os satisfeitos da própria condição; e os homens - seres racionais - qualidade que os torna conscientes da miséria de suas condições. 
O tédio seria o grande "vilão" da condição humana, pois conforme afirma o pastor, ele não deseja nada em particular, tanto menos tem algum motivo para se lamentar, e é esse o pior aspecto do tédio: ser algo contrário à razão, não dependendo, portanto, de uma insatisfação ou de uma dor em particular $^{124}$.

Afortunado é o rebanho por provar prazer, seja ele muito ou pouco. O pastor não se lamenta do fato de provar poucos prazeres em sua vida, aquilo que realmente o aflige é o sentimento de tédio que domina os homens.

Leopardi, por muito tempo, considerou o tédio como o mal mais trágico da condição humana, já que proporcionava, sem um real motivo, um sentimento de vazio na alma, por não conseguir alcançar a felicidade almejada, por mais que se esforçasse. Em um segundo momento, o poeta passou a considerar o tédio não somente como o mal mais trágico do homem, mas paradoxalmente como o mais sublime dos sentimentos humanos. Leopardi trata de tal temática em um "pensiero", mais precisamente no LXVIII, coletado na obra Pensieri publicada postumamente, em 1845.

La noia è in qualche modo il più sublime dei sentimenti umani. [...] il non potere essere soddisfatto da alcuna cosa terrena, né, per dir così, dalla terra intera; considerare l'ampiezza inestimabile dello spazio, il numero e la mole maravigliosa dei mondi, e trovare che tutto è poco e piccino alla capacità dell'animo proprio; immaginarsi il numero dei mondi infinito, e l'universo infinito, e sentire che l'animo e il desiderio nostro sarebbe ancora più grande che sì fatto universo; e sempre accusare le cose d'insufficienza e di nullità, e patire mancamento e vòto, e però noia, pare a me il maggior segno di grandezza e di nobiltà, che si vegga della natura umana. Perciò la noia è poco nota agli uomini di nessun momento, e pochissimo o nulla agli altri animali ${ }^{125}$.

\footnotetext{
${ }^{124}$ Leopardi define o que é o tédio no Zibaldone [4498]: "L'assenza di ogni special sentimento di male e di bene, ch'è lo stato più ordinario della vita, non è nè indifferente, nè bene, nè piacere, ma dolore e male. Ciò solo, quando d'altronde i mali non fossero più che $\mathrm{i}$ beni, nè maggiori di essi, basterebbe a piegare incomparabilmente la bilancia della vita e della sorte umana dal lato della infelicità. Quando l'uomo non ha sentimento di alcun bene o male particolare, sente in generale l'infelicità nativa dell'uomo, e questo è quel sentimento che si chiama noia. (4 Maggio 1829)

"A ausência de cada especial sentimento de mal e de bem que é o estado mais comum da vida, não é nem indiferente, nem bem, nem prazer, mas dor e mal. Só isso, quando por outro lado os males não fossem mais do que os bens, nem maiores do que esses, bastaria pesar incomparavelmente a balança da vida e da sorte humana para o lado da infelicidade. Quando o homem não tem sentimento de nenhum bem ou mal em particular, sente geralmente a infelicidade nativa do homem, e isso é aquele sentimento que se chama tédio." (4 de maio de 1829) - [Trad. nossa]

${ }^{125}$ LEOPARDI, G. "Pensieri", Milano: BUR, 2002, p. 55

"O tédio é, a certos respeitos, o mais sublime dos sentimentos humanos. [...] o fato de não se satisfazer de nenhuma coisa terrena, nem, por assim dizer, da Terra inteira; de considerar a amplitude inestimável do espaço, o número e a imponência maravilhosa dos mundos e descobrir como tudo é mísero e pequeno diante de nossa alma; de imaginar
} 
Quando o homem defronta-se com a própria limitação e insignificância diante da natureza universal em que está inserido, ele percebe o profundo abismo que separa seus ideais, suas aspirações, e sua potencialidade da realidade imposta pelo destino. O sentimento que nasce dessa concepção, o tédio, torna-se o mais evidente símbolo da nobreza e grandeza de um homem, mas que não o livra da infelicidade. Em melhores condições está aquele que não sente as consequências de não conseguir conciliar suas aspirações com a realidade em que vive, ou simplesmente aquele que não pensa, como é o caso dos animais.

\section{Sexta estrofe: tudo é dor}

Uma vez conscientizado da condição de infelicidade que aflige o homem, o pastor inicia a brincar com a sua fantasia.

Forse s'avess'io l'ale

Da volar su le nubi,

135E noverar le stelle ad una ad una

O come il tuono errar di giogo in giogo,

Più felice sarei, dolce mia greggia,

Più felice sarei, candida luna.

$O$ forse erra dal vero,

140Mirando all'altrui sorte, il mio pensiero:

forse in qual forma, in quale

Stato che sia, dentro covile o cuna,

È funesto a chi nasce il dì natale.
Mas se asas eu tivesse

De voar sobre as nuvens, Cada estrela contar que lá flutua,

$\mathrm{Ou}$, qual trovão, errar de pico em pico, Seria eu mais feliz, doce rebanho, Seria eu mais feliz, cândida lua.

E talvez desatino

Este meu cogitar de outro destino:

Funéreo por igual,

Venha ele ao mundo em berço ou em cafua,

É, a quem nasce, o seu dia natal.

Talvez, se ele pudesse superar os limites da natureza humana, se lhe fosse permitido se destacar da terra, voar além das nuvens, contar de uma em uma as estrelas, percorrer os montes de um pico ao outro, como se fosse um trovão, ele alcançaria a felicidade.

Bela é a construção dos versos 135 e 136, em que as expressões ecoantes "ad una ad una" e "di giogo in giogo" servem a estender ao infinito o número de estrelas e de picos, ampliando também a extensão percorrida pelo pastor. A expressão ecoante, na tradução brasileira, é mantida 
somente em relação aos picos "errar de pico em pico", enquanto que para as estrelas, a solução encontrada por José Paulo Paes foi demonstrar o flutuar de "cada estrela" pelo céu, de modo a criar movimento de expansão no verso.

Ao tentar alcançar a felicidade, o pastor lembra-se de seus interlocutores: a cândida lua e o doce rebanho. O adjetivo "dolce" atribuído ao seu rebanho sugere uma relação de ternura existente entre o pastor e suas companheiras de viagem; enquanto que o adjetivo "candida", relacionado aos demais adjetivos atribuídos à lua (vergine - intatta), serve a fazê-lo lembrar da incolumidade lunar em relação às misérias humanas. Ao construir uma anáfora entre o início dos versos 137 e 138, sugere-se existir uma unidade entre os dois interlocutores, sendo ambos livres de angustias.

Breve, porém, é o sonhar do pastor. Logo ele percebe que talvez esse seu modo de pensar, invejando a vida das demais criaturas, por acreditar que elas conheçam a felicidade, e principalmente por crer que em outra forma de vida ele também possa ser feliz, seja errôneo. $\mathrm{O}$ seu modo de pensar desvia da verdade, talvez porque para qualquer forma, ou para qualquer condição, sendo o ser um animal ou um humano, é desventura o seu nascer.

Por bem três vezes aparece na última estrofe o advérbio "forse" (vv. 133, 139 e 141). Diferentemente de quanto ocorrido na quinta estrofe (v. 106 e 109) onde a presença de termos dubitativos servia a demonstrar o pensamento do poeta ainda em formulação em relação à felicidade presente na vida dos animais; nessa última estrofe o advérbio "forse", quase que indica paradoxalmente uma certeza, servindo mais para criar uma atmosfera privada de limites, efeito esse indefinido que se espalha por toda a estrofe.

Forte e sentenciosa é a mensagem conclusiva do poema. Lá onde consta que a vida para o pastor é um mal (v. 104), vem aqui se estender, envolvendo todos os seres vivos na sorte inevitável de dor. É o “pessimismo cósmico” leopardiano presente na mensagem final. 
3.4 O PERFUME EXALADO DE UMA FLOR DO DESERTO

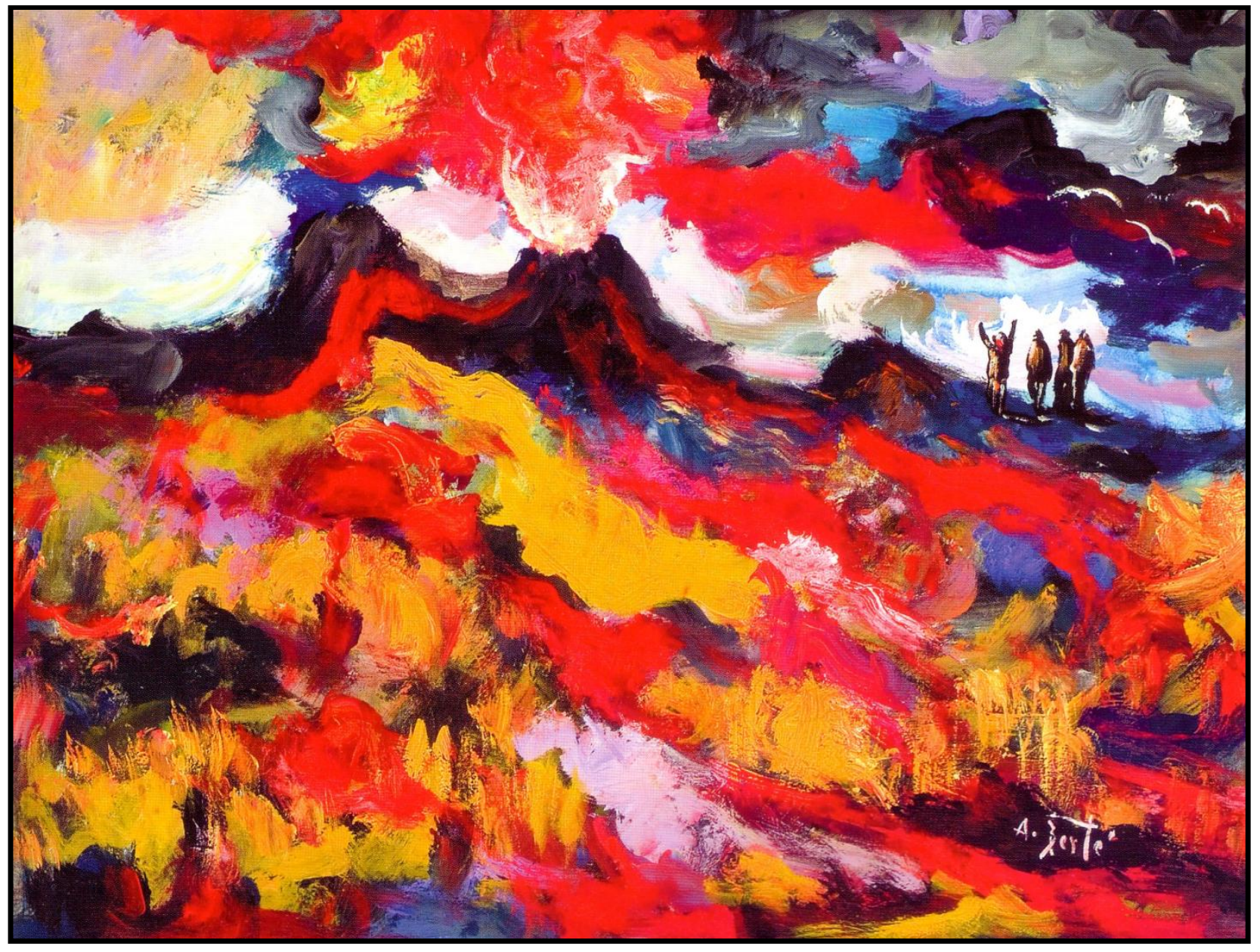

LA GINESTRA N² - Antonio Bertè 


\subsection{O PERFUME EXALADO DE UMA FLOR DO DESERTO: pessimismo heroico}

Uma vez identificada a natureza como a verdadeira culpada pela infelicidade dos seres vivos, Leopardi direciona agora a sua atenção ao modo como o homem deveria se comportar, uma vez conscientizado de seu destino.

Por mais que o homem esteja condenado a um destino de dor e de infelicidade, ele não deve se entregar covardemente, como forma de escapismo, ao suicídio, por exemplo. Em uma das Operette morali, mais precisamente no Dialogo di Plotino e Porfirio (escrito em 1827), Leopardi trata sobre o tema do suicídio, não o defendendo como solução ao drama existencial. $\mathrm{Na}$ passagem a seguir, Plotino, uma das personagens, incentiva seu amigo, Porfirio, a não dar cabo de sua vida:

Viviamo, Porfirio mio, e confortiamoci insieme: non ricusiamo di portare quella parte che il destino ci ha stabilita, dei mali della nostra specie. Sì bene attendiamo a tenerci compagnia l'un l'altro; e andiamoci incoraggiando, e dando mano e soccorso scambievolmente; per compiere nel miglior modo questa fatica della vita. La quale senza alcun fallo sarà breve. E quando la morte verrà, allora non ci dorremo: e anche in quell'ultimo tempo gli amici e i compagni ci conforteranno: e ci rallegrerà il pensiero che, poi che saremo spenti, essi molte volte ci ricorderanno, e ci ameranno ancora ${ }^{126}$. (1995, p.319)

Visto que a vida do ser humano já é cheia de sofrimento, o suicídio de uma pessoa só lhe acrescentará mais sofrimento. A solução para suportar seus males seria de outro gênero: "andiamoci incoraggiando, e dando mano e soccorso scambievolmente; per compiere nel miglior modo questa fatica della vita ${ }^{127}$, , ou seja, a melhor coisa a se fazer é seguir o caminho da solidariedade humana, de modo a enfrentar unidos o inimigo comum.

Contrariamente aos críticos que se referiam à filosofia leopardiana como sendo adversa à sociedade e aos homens, Leopardi, dois anos mais tarde dirá no Zibaldone [4428]:

\footnotetext{
126 "Vivamos, Porfírio meu, e confortemo-nos juntos: não recusemos carregar aquela parte que o destino nos legou dos males da nossa espécie. Atentemos bem em fazer companhia um ao outro e encorajemo-nos, dando-nos as mãos e trocando socorro para cumprir, da melhor maneira, esta tarefa da vida, que infalivelmente será breve. E quando vier a morte então não nos lamentaremos e, naquele último instante, os amigos e companheiros nos confortarão. $\mathrm{E}$ nos alegrará o pensamento de que, depois que tivermos passado, eles nos recordarão muitas vezes e nos amarão ainda." [Trad. LUCCHESI, 1996, p. 448]

${ }^{127}$ Atentemos bem em fazer companhia um ao outro e encorajemo-nos, dando-nos as mãos e trocando socorro para cumprir, da melhor maneira, esta tarefa da vida" - [Trad. LUCCHESI, 1996, p. 448]
} 
"La mia filosofia, non solo non è conducente alla misantropia, come può parere a chi la guarda superficialmente, e come molti l'accusano; ma di sua natura esclude la misantropia, di sua natura tende a sanare, a spegnere quel mal umore, quell'odio, non sistematico, ma pur vero odio, che tanti e tanti, i quali non sono filosofi, e non vorrebbono esser chiamati nè creduti misantropi, portano però cordialmente a' loro simili, sia abitualmente, sia in occasioni particolari, a causa del male che, giustamente o ingiustamente, essi, come tutti gli altri, ricevono dagli altri uomini. La mia filosofia fa rea d'ogni cosa la natura, e discolpando gli uomini totalmente, rivolge l'odio, o se non altro il lamento, a principio più alto, all'origine vera de' mali de' viventi. ec. ec ${ }^{128}$."(2 Gennaio 1829)

Graças à razão, o homem pode individuar o seu verdadeiro inimigo, e com isso combatêlo, não de forma soberba, acreditando-se superior ao inimigo, ou de forma covarde, perdendo a sua dignidade; mas com uma consciência vigorosa, aceitando heroicamente o seu destino. A nobreza do homem, para Leopardi, está propriamente na conscientização dessa amarga verdade.

A ideia leopardiana de progresso diverge da do seu tempo. Para o poeta, o progresso é do tipo moral e civil, indo contra as correntes otimistas da época, que é marcada pela busca do poder e do sucesso. Aquilo que realmente se faz necessário para o homem é a conscientização da situação humana, visando construir uma sociedade mais justa, baseada na solidariedade; somente assim o homem poderá combater a natureza. É com esse espírito heroico que surge o poema $L a$ ginestra, ${ }^{129}$ o il fiore del deserto, analisado a seguir.

128 “A minha filosofia, não só não conduz à misantropia, como pode parecer para aqueles que a analisam superficialmente, e como muitos a acusam; mas por sua natureza exclui a misantropia, por sua natureza tende a sanar, a acabar com aquele mau humor, aquele ódio, não sistemático, mas mesmo assim ódio verdadeiro, que muitos e muitos, não filósofos, que não gostariam de serem chamados nem considerados como misantropos, mas que atribuem cordialmente aos seus símiles, seja costumeiramente, seja em particulares ocasiões, a causa do mal que, justamente ou injustamente, eles, como todos os demais, recebem dos outros homens. A minha filosofia faz ré de todas as coisas a natureza, e tirando a culpa dos homens totalmente, dirige o ódio, ou se não o lamento, ao princípio maior, à origem verdadeira dos males dos seres vivos, etc. etc. (2 de janeiro de 1829) - [Trad. nossa]

${ }^{129}$ A flor spartium junceum, também conhecida popularmente na Itália como "ginestra" é uma planta arbustiva de textura semi-lenhosa, cujos ramos são finos, flexíveis, verdes e longos; as folhas são pequenas, dispostas esparsamente na ramagem e adaptadas para reduzir a perda de água por transpiração e as numerosas flores são grandes, perfumadas e de coloração tipicamente amarelo-intenso. 


\subsubsection{LA GINESTRA, O IL FIORE DEL DESERTO de Leopardi no Brasil}

"La ginestra,
o il fiore del deserto"

E gli uomini vollero piuttosto

le tenebre che la luce.

Giovanni, III, 19.

Qui su 1'arida schiena

Del formidabil monte

Sterminator Vesevo,

La qual null'altro allegra arbor né fiore,

05 Tuoi cespi solitari intorno spargi,

Odorata ginestra,

Contenta dei deserti. Anco ti vidi

De' tuoi steli abbellir l'erme contrade

Che cingon la cittade

10 La qual fu donna de' mortali un tempo,

E del perduto impero

Par che col grave e taciturno aspetto

Faccian fede e ricordo al passeggero.

Or ti riveggo in questo suol, di tristi

15 Lochi e dal mondo abbandonati amante,

E d'afflitte fortune ognor compagna.

Questi campi cosparsi

Di ceneri infeconde, e ricoperti

Dell'impietrata lava,

20 Che sotto i passi al peregrin risona;

Dove s'annida e si contorce al sole

La serpe, e dove al noto

Cavernoso covil torna il coniglio;

Fur liete ville e colti,

25 E biondeggiàr di spiche, e risonaro

Di muggito d'armenti;

Fur giardini e palagi,

Agli ozi de' potenti

Gradito ospizio; e fur città famose,

30 Che coi torrenti suoi l'altero monte

Dall'ignea bocca fulminando oppresse

Con gli abitanti insieme. Or tutto intorno

Una ruina involve,

Dove tu siedi, o fior gentile, e quasi

35 I danni altrui commiserando, al cielo

Di dolcissimo odor mandi un profumo,

Che il deserto consola. A queste piagge

Venga colui che d'esaltar con lode

Il nostro stato ha in uso, e vegga quanto

40 È il gener nostro in cura
"A giesta,

ou a flor do deserto"

E os homens amaram mais as trevas do que a luz.

João, III, 19.

Aqui na árida encosta

Do pavoroso monte,

O destruidor Vesúvio,

A que não alegra outra planta ou flor, as tuas moitas solitárias vertem,

Perfumada giesta,

Contente com os desertos. Com teus caules

Eu te vi dar encanto aos ermos campos

Que cercam a cidade

A qual foi dona dos mortais um tempo,

E do perdido império

Com o seu grave e taciturno aspecto

Dá fé e testemunho aos que aqui passam.

Eu volto a ver-te neste chão, amante

De lugares do mundo abandonados,

E de infelizes fados companheira.

Estes campos regados

De cinzas infecundas, recobertos

De lava feita em pedras

Que ecoa quando a pisa o peregrino;

Onde se aninha e se retorce ao sol

A serpente, e onde ao velho

Cavernoso covil retorna o coelho;

Foram vilas, cultivos

E lourejar de espigas, e onde ecoaram

Mugidos de rebanhos;

Foram jardins, palácios,

Do ócio de poderosos

Aprazível refúgio; e até cidades

Que com torrentes o altaneiro monte

De boca em fogo fulminou destruindo-as

$\mathrm{E}$ aos habitantes junto. Agora a tudo

Uma ruína envolve,

Onde tu pousas, flor gentil, e como

Que os danos de outros deplorando, ao céu

De dulcíssimo odor dás um perfume

Que consola o deserto. A estas plagas

Acorra aquele que a exaltar com loas

A nossa condição, constate quanto

A espécie nossa é presa 
All'amante natura. E la possanza

Qui con giusta misura

Anco estimar potrà dell'uman seme,

Cui la dura nutrice, ov'ei men teme,

45 Con lieve moto in un momento annulla

In parte, e può con moti

Poco men lievi ancor subitamente

Annichilare in tutto.

Dipinte in queste rive

50 Son dell'umana gente

Le magnifiche sorti e progressive.

Qui mira e qui ti specchia,

Secol superbo e sciocco,

Che il calle insino allora

55 Dal risorto pensier segnato innanti

Abbandonasti, e volti addietro i passi,

Del ritornar ti vanti,

E procedere il chiami.

Al tuo pargoleggiar gl'ingegni tutti,

60 Di cui lor sorte rea padre ti fece

Vanno adulando, ancora

Ch'a ludibrio talora

T'abbian fra se. Non io

Con tal vergogna scenderò sotterra;

65 Ma il disprezzo piuttosto che si serra

Di te nel petto mio,

Mostrato avrò quanto si possa aperto:

Ben ch'io sappia che obblio

Preme di troppo all'età propria increbbe.

70 Di questo mal, che teco

Mi fia comune, assai finor mi rido.

Libertà vai sognando, e servo a un tempo

Vuoi di nuovo il pensiero,

Sol per cui risorgemmo

75 Della barbarie in parte, e per cui solo

Si cresce in civiltà, che sola in meglio

Guida i pubblici fati.

Così ti spiacque il vero

Dell'aspra sorte e del depresso loco

80 Che natura ci diè. Per questo il tergo

Vigliaccamente rivolgesti al lume

Che il fe palese: e, fuggitivo, appelli

Vil chi lui segue, e solo

Magnanimo colui

85 Che se schernendo o gli altri, astuto o folle, Fin sopra gli astri il mortal grado estolle.

Uom di povero stato e membra inferme

Che sia dell'alma generoso ed alto, Non chiama se né stima
$\grave{A}$ amante natureza. E o poder todo

Que com justa clareza

Poderá estimar da humana raça

O que a dura nutriz, sem ameaça,

Com leves baques num momento anula

Em parte, e em movimentos

Menos leves então subitamente

Reduz em pouco a nada.

Aqui pintados, vivos,

Estão da humana gente

Destinos de grandeza e progressivos.

Aqui olha e te espelha,

Século altivo e tolo,

Que o atalho até então

Ao pensamento assinalado antes

Abandonaste, e atrás voltando os passos,

Do retorno te ufanas

E de progresso o chamas.

A teu infantilismo esses engenhos,

De cujo malefício pai te fez

Vão adulando, embora

Com ludíbrio talvez

Dentro de si. Não eu:

Vergonha tal não terei sob a terra,

Sem que o grande desprezo que se encerra

Por ti no peito meu

$\mathrm{Eu}$ mostre o mais que possa abertamente:

Sabendo bem que o olvido

Oprime quem lamenta a própria época.

É mal comum a nós

Do qual me rio muito até agora.

Liberdade sonhando, e servo a um tempo

Queres o pensamento

Pelo qual ressurgimos

Nós da barbárie, e pelo qual se cresce

Em civilização, a que melhor pode

Guiar os feitos públicos.

Assim doeu-te a verdade

Da sorte áspera e ínfima paragem

Destinadas a ti. Por isso o dorso

Covardemente dirigiste à luz

Que o revelou: e fugitivo chamas

De vil a quem o segue

E magnânimo aquele

Que a rir de si e de outros, fino ou louco,

Aos astros o mortal eleva em troco.

O homem que é pobre e tem o corpo enfermo,

Contudo de alma generoso e nobre,

Não se diz nem se estima 
90 Ricco d'or né gagliardo,

E di splendida vita o di valente

Persona infra la gente

Non fa risibil mostra;

Ma se di forza e di tesor mendico

95 Lascia parer senza vergogna, e norma

Parlando, apertamente, e di sue cose

Fa stima al vero uguale.

Magnanimo animale

Non credo io già, ma stolto,

100 Quel che nato a perir, nutrito in pene,

Dice, a goder son fatto,

E di fetido orgoglio

Empie le carte, eccelsi fati e nove

Felicità, quali il ciel tutto ignora,

105 Non pur quest'orbe, promettendo in terra

A popoli che un'onda

Di mar commosso, un fiato

D'aura maligna, un sotterraneo crollo

Distrugge sì, ch'avanza

110 A gran pena di lor la rimembranza.

Nobil natura è quella

Che a sollevar s'ardisce

Gli occhi mortali incontra

$\mathrm{Al}$ comun fato, e che con franca lingua,

115 Nulla al ver detraendo,

Confessa il mal che ci fu dato in sorte,

E il basso stato e frale;

Quella che grande e forte

Mostra se nel soffrir, né gli odii e l'ire

120 Fraterne, ancor più gravi

D'ogni altro danno, accresce

Alle miserie sue, l'uomo incolpando

Del suo dolor, ma dà la colpa a quella

Che veramente è rea, che de' mortali

125 Madre è di parto e di voler matrigna.

Costei chiama inimica; e incontro a questa

Congiunta esser pensando,

Siccome è il vero, ed ordinata in pria

L'umana compagnia,

130 Tutti fra se confederati estima

Gli uomini, e tutti abbraccia

Con vero amor, porgendo

Valida e pronta ed aspettando aita

Negli alterni perigli e nelle angosce

135 Della guerra comune. Ed alle offese

Dell' uomo armar la destra, e laccio porre

$\mathrm{Al}$ vicino ed inciampo,

Stolto crede così qual fora in campo

Cinto d'oste contraria, in sul più vivo

140 Incalzar degli assalti,
Rico em ouro e galhardo,

E de esplêndida vida ou de valente

Pessoa em meio à gente

Não faz visível mostra;

Mas se de bens e de vigor mendigo

Se diz sem se vexar, e isto declara

Falando abertamente, a suas coisas

Dá o valor legal.

Magnânimo animal

Não creio já, mas tolo,

Quem nascido mortal, de dor nutrido,

Diz: para gozar fui feito,

E de um abjeto orgulho

Enche os papéis, excelsos fados, novas

Felicidades, que no céu se ignora,

Mas este mundo, a prometer na terra

A povos que uma onda

De mar movido, um sopro

De aura maligna, um subterrâneo abalo

Tanto destrói que apenas

Deles fica a lembrança a duras penas.

Que nobre natureza

Essa que a erguer se atreve

Os olhos mortais contra

O comum fado, e que com franca língua

Dizendo só verdades

Confessa o mal a nós dado por sorte,

E o baixo estado e o frágil;

Essa que grande e forte

Mostrar-se no sofrer, sem ódios e iras

Fraternas, bem mais graves

Que qualquer dano junta

Às misérias que sofre, o homem culpado

Por sua dor, mas não culpando aquela

Que na verdade é ré, e dos mortais

Mãe é no parto e no querer madrasta.

A esta chama inimiga, e contra ela

Crendo estar coligada,

Como está, e ordenada desde sempre

A humana companhia,

Como entre si confederados julga

Os homens e os abraça

Com amor, ofertando

E esperando vital e pronta ajuda

Nos perigos diversos e na angústia

Da guerra que sustentam. E às ofensas

Do homem armar a destra e estender laços

E óbices ao vizinho,

Estulto crê assim como em caminho

Cheio de hostes contrárias, no mais vivo

Acossar dos assaltos, 
Gl'inimici obbliando, acerbe gare

Imprender con gli amici,

E sparger fuga e fulminar col brando

Infra i propri guerrieri.

145 Così fatti pensieri

Quando fien, come fur, palesi al volgo,

E quell'orror che primo

Contra l'empia natura

Strinse i mortali in social catena,

150 Fia ricondotto in parte

Da verace saper, l'onesto e il retto

Conversar cittadino,

E giustizia e pietade, altra radice

Avranno allor che non superbe fole,

155 Ove fondata probità del volgo

Così star suole in piede

Quale star può quel ch'ha in error la sede.

Sovente in queste rive,

Che, desolate, a bruno

160 Veste il flutto indurato, e par che ondeggi,

Seggo la notte; e su la mesta landa

In purissimo azzurro

Veggo dall'alto fiammeggiar le stelle,

Cui di lontan fa specchio

165 Il mare, e tutto di scintille in giro

Per lo vòto seren brillare il mondo.

E poi che gli occhi a quelle luci appunto,

Ch'a lor sembrano un punto,

E sono immense, in guisa

170 Che un punto a petto a lor son terra e mare

Veracemente; a cui

L'uomo non pur, ma questo

Globo ove l'uomo è nulla,

Sconosciuto è del tutto; e quando miro

175 Quegli ancor più senz'alcun fin remoti

Nodi quasi di stelle,

Ch'a noi paion qual sabbia, a cui non l'uomo

E non la terra sol, ma tutte in uno,

Del numero infinite e della mole,

180 Con l'aureo sole insiem, le nostre stelle

$\mathrm{O}$ sono ignote, o così paion come

Essi alla terra, un punto

Di luce nebulosa; al pensier mio

Che sembri allora, o prole

185 Dell'uomo? E rimembrando

Il tuo stato quaggiù, di cui fa segno

Il suol ch'io premo; e poi dall'altra parte,

Che te signora e fine

Credi tu data al Tutto, e quante volte

190 Favoleggiar ti piacque, in questo oscuro
Inimigos largando, acerbas brigas

Tendo com os amigos,

Correr como a fugir brandindo espadas

Contra os próprios guerreiros.

Tais fatos, quando inteiros

Deles souber, e de outros mais, o vulgo,

E aquele horror que outrora

Contra a má natureza

Constrangeu os mortais numa cadeia,

Se recupere em parte

Pelo vero saber, o honesto e reto

Consórcio citadino,

E justiça e piedade outra raiz

Terão então, não as soberbas crenças

Em que baseia o vulgo a probidade

Como tem seu sustento

Aquele que conserva no erro o assento.

Não raro nesta plaga,

Que, desoladas, veste

De escuro a lava, e que, parece, ondeiam,

Sento-me à noite; e sobre a erma charneca

Em puríssimo azul

Contemplo no alto o flamejar de estrelas,

Às quais serve de espelho

O mar, e de cintilações em torno

Faz no ar sereno reluzir o mundo.

Se os olhos para as luzes eu aponto

Parecem-lhes um ponto,

E são imensas, tanto

Que, comparado, um ponto são a terra

E o mar, é fato; e o homem,

Não só ele, mas este

Globo onde o homem é nada,

Desconhecido é todo; e quando miro

Aqueles mais remotos, infinitos

E quase nós de estrelas,

Que nos parecem névoa, aos quais não o homem

E não a terra só, mas eles todos,

De número infinito, juntamente

Com o áureo sol também,

Ou são ignotas, ou assim nos lembram

Elas a terra, um ponto

De nebulosa luz; ao pensar meu

O que és então, ó raça

Do homem? E relembrando

A tua condição, testemunhada

Pelo solo em que piso; e, do outro lado,

Que tu senhora e fim

Te crês ao Todo dada, e quantas vezes

Te peço que fabules neste escuro 
Granel di sabbia, qual di terra ha nome,

Per tua cagion, dell'universe cose

Scender gli autori, e conversar sovente

Co' tuoi piacevolmente, e che i derisi

195 Sogni rinnovellando, ai saggi insulta

Fin la presente età, che in conoscenza

Ed in civil costume

Sembra tutte avanzar; qual moto allora, Mortal prole infelice, o qual pensiero

200 Verso te finalmente il cor m'assale?

Non so se il riso o la pietà prevale.

Come d'arbor cadendo un picciol pomo,

Cui là nel tardo autunno

Maturità senz' altra forza atterra,

205 D'un popol di formiche i dolci alberghi,

Cavati in molle gleba

Con gran lavoro, e l'opre

E le ricchezze che adunate al tempo estivo,

Con lungo affaticar l'assidua gente

210 Avea provvidamente al tempo estivo,

Schiaccia, diserta e copre

In un punto; così d'alto piombando,

Dall'utero tonante

Scagliata al ciel, profondo

215 Di ceneri e di pomici e di sassi

Notte e ruina, infusa

Di bollenti ruscelli,

O pel montano fianco

Furiosa tra l'erba

220 Di liquefatti massi

E di metalli e d'infocata arena

Scendendo immensa piena,

Le cittadi che il mar là su l'estremo

Lido aspergea, confuse

225 E infranse e ricoperte

In pochi instanti: onde su quelle or pasce

La capra, e città nove

Sorgon dall'altra banda, a cui sgabello

Son le sepolte, e le protrate mura

230 L'arduo monte al suo piè quasi calpesta.

Non ha natura al seme

Dell'uom più stima o cura

Ch'alla formica: a se più rara in quello

Che nell'altra è la strage,

235 Non avvien ciò d'altronde

Fuor che l'uom sue prosapie ha men feconde.

Ben mille ed ottocento

Anni varcàr poi che spariro, oppressi

Dall'ignea forza, i popolati seggi,
Grão de areia a que todos chamam terra

E que, por tua causa, do universo

Baixaram os autores e falaram

De bom grado com os teus, e que ilusórios

Sonhos a renovar, insulta os sábios

Neste século que em conhecimentos

E cívico costume

Parece tudo superar; que impulso,

Mortal raça infeliz, que pensamento

Por ti então meu coração invade?

Não sei se é mais o riso ou a piedade.

Qual da árvore ao cair pequeno pomo

Que pelo fim do outono

Sem outra força a madurez derruba,

Um formigueiro e os seus doces abrigos

Feitos na terra mole

Com persistência, e as obras

$\mathrm{E}$ as riquezas que com muita porfia

E um sem fim de fadiga a assídua gente

Havia no verão provisionado,

Esmaga, arrasa e cobre

Em pouco tempo; assim do alto atirando-se

Do útero trovejante

Lançada ao céu profundo,

De cinzas e de lavas e de pedras

Noite e ruína mista

De ferventes arroios,

Ou descendo a montanha

Com fúria em meio à relva

De rochas liquefeitas

E de metais e de abrasada areia

Baixando imensa cheia,

As cidades que o mar lá longe a praia

Banhava, confundiu,

Quebrou e recobriu

Num só instante: onde agora a cabra

Pasta, e cidades novas

Se fazem do outro lado, as sepultadas

Dando-lhes base, e os muros derrubados

$\mathrm{O}$ árduo monte a seus pés quase repisa.

Não tem a natureza

Mais cuidado com o homem

Do que com a formiga, e se mais raro é nela

Do que na outra o estrago,

Isto se dá, no fundo,

Em razão de o homem ser menos fecundo.

Mil e oitocentos anos

Passaram-se depois de destruídas

Pela ígnea força as vilas e cidades, 
240 E il villanello intento

Ai vigneti, che a stento in questi campi

Nutre la morta zolla e incenerita,

Ancor leva lo sguardo

Sospettoso alla vetta

245 Fatal, che nulla mai fatta più mite

Ancor siede tremenda, ancor minaccia

A lui strage ed ai figli ed agli averi

Lor poverelli. E spesso

Il meschino in sul tetto

250 Dell'ostel villereccio, ala vagante

Aura giacendo tutta notte insonne,

E balzando più volte, esplora il corso

Del temuto bollor, che si riversa

Dall'inesausto grembo

255 Sull'arenoso dorso, a cui riluce

Di Capri la marina

E di Napoli il porto e Mergellina.

E se appressar lo vede, o se nel cupo

Del domestico pozzo ode mai l'acqua

260 Fervendo gorgogliar, desta i figliuoli,

Desta la moglie in fretta, e via, con quanto

Di lor cose rapir posson, fuggendo,

Vede lontan l'usato

Suo nido, e il picciol campo

265 Che gli fu dalla fama unico schermo,

Preda al flutto rovente,

Che crepitando giunge, e inesorato

Durabilmente sovra quei si spiega.

Torna al celeste raggio

270 Dopo l'antica obblivion l'estinta

Pompei, come sepolto

Scheletro, cui di terra

Avarizia o pietà rende all'aperto;

E dal deserto foro

275 Diritto infra le file

De' mozzi colonnati il peregrino

Lunge contempla il bipartito giogo

E la creta fumante,

Che alla sparsa ruina ancor minaccia.

280 E nell'orror della secreta notte

Per li vacui teatri,

Per li templi deformi e per le rotte

Case, ove i parti il pipistrello asconde,

Come sinistra face

$\mathbf{2 8 5}$ Che per voti palagi atra s'aggiri,

Corre il baglior della funerea lava,

Che di lontan per l'ombre

Rosseggia e i lochi intorno intorno tinge.

Così, dell'uomo ignara e dell'etadi

290 Ch'ei chiama antiche, e del seguir che fanno
E o camponês, com planos

De bem cuidar das vinhas que nos campos

A morta e incinerada gleba nutre,

Levanta o olhar ainda

Medroso para o cume

Fatal que lá, talvez nunca amansado

E ainda apavorante, é ameaça

De estragos a ele, aos filhos e aos haveres

Dos pobrezinhos. Sempre

O coitado, no teto

Da sua casinhola, às intempéries

Exposto, passa a noite inteira insone

E erguendo-se de um salto observa o curso

Do temido fervor que se derrama

Do ventre inesgotável

Sobre o arenoso dorso, reluzindo

Na marina de Capri,

Em Nápoles, no porto e em Margelina.

E vendo aproximar-se, ou se no fundo

Da cisterna da casa estiver a água

Gorgolejando, ele desperta os filhos

Às pressas e a mulher e então, com quanto

Pode pegar do que possui, fugindo

Olha de longe o seu

Ninho e o pequeno campo

Que foi da fome a sua só defesa,

Presa do fluxo ardente

Que crepitando vem e inexorável

Para sempre sobre eles se derrama.

Retorna à luz do céu

Depois de longo esquecimento a extinta

Pompéia, um esqueleto

Sepulto que da terra

Avareza ou piedade põe à mostra;

E do deserto fórum

De pé por entre as filas

De colunas quebradas o viandante

Contempla ao longe o bipartido cume

E a crista fumegante

Que a dispersa ruína ainda ameaça.

E no terrível da profunda noite

Pelos teatros vazios,

Pelos templos sem forma e pelas rotas

Casas, onde o morcego guarda as crias,

Como sinistro facho

Que por ermos palácios, negro gira,

Corre a fulgência da funérea lava

Que de longe entre sombras

De tons vermelhos tinge tudo em torno.

Assim, do homem ignaro e das idades

Que antigas ele chama, e da seqüência 
Dopo gli avi i nepoti,

Sta natura ognor verde, anzi procede

Per sì lungo cammino

Che sembra star. Caggiono i regni intanto,

295 Passan genti e linguaggi: ella nol vede:

E l'uom d'eternità s'arroga il vanto.

$\mathrm{E}$ tu, lenta ginestra,

Che di selve odorate

Queste campagne dispogliate adorni,

300 Anche tu presto alla crudel possanza

Soccomberai del sotterraneo foco,

Che ritornando al loco

Già noto, stenderà l'avaro lembo

Su tue molli foreste. E piegherai

305 Sotto il fascio mortal non renitente

Il tuo capo innocente:

Ma non piegato insino allora indarno

Codardamente supplicando innanzi

$\mathrm{Al}$ futuro oppressor; ma non eretto

310 Con forsennato orgoglio inver le stelle,

Né sul deserto, dove

E la sede e i natali

Non per voler ma per fortuna avesti;

Ma più saggia, ma tanto

315 Meno inferma dell'uom, quanto le frali

Tue stirpi non credesti

$\mathrm{O}$ dal fato o da te fatte immortali.

[Giacomo Leopardi]
Depois de avós os netos,

E sempre verde a natureza ao ir-se

Por tão longo caminho

Como imóvel. Caem reinos todavia,

Passam povos e línguas: ela ignora,

E o homem de ser eterno se gloria.

E tu, lenta giesta

Que com matos cheirosos

Adornas estes campos despojados,

Também tu, prestes, à cruel potência

Sucumbirás ao subterrâneo fogo,

Que retornando ao sítio

De antes, estenderá o avaro manto

Sobre teus tenros bosques. Sob o peso

Mortal hás de dobrar não renitente

A cabeça inocente:

Mas não dobrada até então, embalde

Covardemente suplicando em face

Do futuro opressor; e nem erguida

Com doido orgulho ao campo das estrelas;

Nem no deserto, onde

Por berço e tudo mais

Que sem vontade por azar tivestes;

Porém mais sábia e menos

Débil que os homens, frágeis por demais,

Tuas raças não creste,

Pelo fado ou teus feitos, imortais.

\section{[Tradução de Affonso Félix de Sousa]}

Composto em 1836, o poema La ginestra, o il fiore del deserto foi publicado depois da morte do autor, em 1845, em uma edição acrescida, organizada e corrigida, conforme o último entendimento do autor, sob os cuidados de Antonio Ranieri, pela editora Le Monier, em Florença.

Do ponto de vista formal, o poema é composto de sete estrofes de tamanhos diferentes [30 versos, 35 versos, 71 versos, 44 versos, 35 versos, 60 versos e 21 versos], sendo no total 317 versos, sendo eles hexassílabos e decassílabos, conforme a contagem métrica brasileira, livremente distribuídos. 
Quanto ao esquema rímico, o poema apresenta um jogo livre de repetições sonoras, com algumas rimas alternadas e no meio dos versos. Ao longo do poema, é possível encontrar também duplas de rimas toantes: vv. 40 - 45 “cura - natura-misura-dura-annulla".

O poeta, ao longo do poema, apresenta cenas que se referem à história, para que sirvam de exemplo para futuros comportamentos dos homens. Para chamar a atenção dos homens, o poeta faz uso de recursos como o ritmo - o efeito musical criado doa um tom melancólico e ao mesmo tempo energético ao poema; bem como os tempos verbais - o uso do "passato remoto" faz alusão a fatos históricos já acontecidos no mesmo local, onde está hoje a “odorata ginestra”, e a sua redondeza. Já a utilização do tempo presente nos remete ao momento da descrição, ou melhor, da mensagem de alerta ao ser humano sendo declamada pelo poeta. A mudança para o tempo futuro acontece no momento em que se direciona a reflexão para o futuro da raça humana: o sucumbir do homem diante da potência da natureza.

Por se tratar de uma considerável composição poética, escolheu-se dividi-la em cinco partes: a giesta - a natureza - o homem - a natureza - a giesta

A giesta: representa o homem humilde que encara o seu destino, já consciente da verdade e resignado, demonstrando assim o seu caráter nobre. Nota-se que a giesta abre e fecha o canto, o que leva a pensar ao renascimento, à sobrevivência, à resistência e a não entrega diante da força de destruição da natureza - a giesta com o seu perfume e beleza vem indicar a alma nobre e pura que refloresce após uma catástrofe.

A natureza: envolve o homem. É ela que dá origem e que aniquila tudo. Sendo assim, percebe-se a potência desmesurada da natureza em relação à fragilidade do gênero humano.

O homem: posto ao centro de tudo vem aqui demonstrar o quão ridícula é a sua soberbia. É o ideal do antropocentrismo, como se a raça humana fosse a dona da Terra e do universo; o que entra em contraste com a potência da natureza, a verdadeira inimiga da humanidade. 
Visto que o poema não está estruturado em estrofes regulares, e por apresentar longos períodos, a análise será feita seguindo uma divisão sintática por períodos, contidos nas cinco partes acima descritas.

\section{Primeira parte: "A giesta" vv. 01-16}

Qui su l'arida schiena

Del formidabil monte

Sterminator Vesevo,

La qual null'altro allegra arbor né fiore,

05 Tuoi cespi solitari intorno spargi,

Odorata ginestra,

Contenta dei deserti. Anco ti vidi

De' tuoi steli abbellir l'erme contrade

Che cingon la cittade

10 La qual fu donna de' mortali un tempo,

E del perduto impero

Par che col grave e taciturno aspetto

Faccian fede e ricordo al passeggero.

Or ti riveggo in questo suol, di tristi

15Lochi e dal mondo abbandonati amante,

E d'afflitte fortune ognor compagna.
Aqui na árida encosta

Do pavoroso monte,

O destruidor Vesúvio,

A que não alegra outra planta ou flor, as tuas moitas solitárias vertem,

Perfumada giesta, Contente com os desertos. Com teus caules Eu te vi dar encanto aos ermos campos Que cercam a cidade

A qual foi dona dos mortais um tempo, E do perdido império

Com o seu grave e taciturno aspecto Dá fé e testemunho aos que aqui passam. Eu volto a ver-te neste chão, amante De lugares do mundo abandonados, E de infelizes fados companheira.

A canção abre-se com uma descrição da paisagem: encosta do vulcão Vesúvio - na cidade de Nápoles, onde está a perfumada giesta. O tom aqui usado na descrição não é de alegria, como faz supor a presença de uma flor tão bela, cheirosa, e radiante de luz, conforme sugere a sua característica cor amarela. Pelo contrário, o tom apresentado parece estar ligado a um sentimento triste, de solidão e sofrimento. A presença das vibrantes /r/ e das expressões que remetem à solidão reforça a sensação de dureza e depressão que a visão deste lugar provoca, recursos que são mantidos na tradução brasileira.

Arida schiena $=$ árida encosta

Formidabil monte $=$ pavoroso monte Sterminator Vesevo = destruidor Vesúvio
A presença dos adjetivos ligados ao vulcão demonstra gradativamente a potência devastadora do Vesúvio. 
A paisagem é de solidão marcada pela dupla negação da vida no verso 4: "la qual null'altro allegra arbor né fiore”, com exceção da giesta, espalhando seus ramos aqui e ali, a qual vinga até mesmo no deserto. Mesmo com a presença da giesta, não se faz esquecer ao leitor a sensação de ausência de vida, pois os ramos são "solitari" (solitários). A presença do pronome relativo "la qual" nesse verso cria um jogo de substituições, pois ora tem a função de sujeito do verso, referindo-se à "schiena” (v. 1), ora tem função de objeto direto da palavra "allegra" (v. 4), dessa forma, para a encosta do vulcão a presença das plantas e flores não é interessante, tampouco elas são atraídas pela encosta.

No segundo período, o eu lírico resgata da memória uma imagem parecida já vista outrora. Assim como a giesta está solitária na encosta do Vesúvio, ele lembra-se de já tê-la visto em um ermo campo que cerca a cidade de Roma, a qual já foi senhora do mundo. Hoje a cidade de Roma está cercada de ruínas austeras e emudecidas pela ausência de vida, as quais servem de testemunho aos visitantes de seu poder já perdido.

Jakobson em seu livro Fonema e fonologia (1972, p.25) diz que o acento lexical demonstra a hierarquia das diversas palavras que compõem uma frase. Portanto, o grau mais elevado de acentuação indica a importância da palavra principal na enunciação. Desta forma, a acentuação mais forte na palavra “erme” presente no verso 8, “de' tuoi steli abbellir l'erme contrade”, anuncia a sua importância. Sendo a ausência de vida o foque em questão, acredita-se querer concentrar a atenção do leitor na ideia de isolamento, pois a giesta está localizada no ermo campo, em contraste com a cidade, centro de vida e de poder, poder esse porém já perdido, conforme lembrado pelo poeta. Conforme visto, o grau elevado da acentuação na palavra "ermo" tem a sua devida importância no verso em que está inserido, cuidado que é levado em consideração pelo tradutor no poema em português.

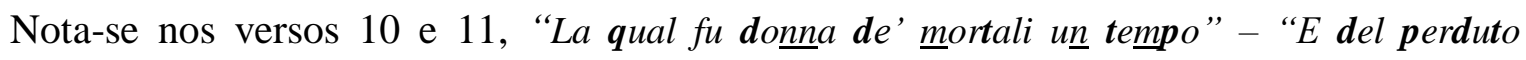
impero”, a presença de fonemas oclusivos e nasais, os quais provocam um obstáculo, interrompem por um momento a corrente respiratória sonora que produz o fonema, desta forma, chama-se a atenção do leitor para a efemeridade das coisas. Roma já foi “donna" - latinismo (senhora) - mas hoje não o é mais. O traço explosivo de tais fonemas transmite uma impressão de força e intensidade. 
Se acopladas as expressões "perduto impero - ricordo al passeggero", percebe-se o belo jogo criado pelo poeta. Se o império foi perdido, hoje se tem somente a sua lembrança (ricordo). A palavra "passeggero" além de indicar aquele que passa pela rua, também se refere àquilo que passa rapidamente, que é transitório. A rima marcada pelas expressões “impero - passeggero”, portanto, indica tal efemeridade das coisas. Na tradução de Affonso Félix de Sousa, a rima em questão não foi mantida, quebrando o jogo criado entre a transitoriedade dos impérios e dos passantes que visitam o local.

No terceiro período desta primeira parte, o eu-lírico retorna ao tempo presente, marcado pela expressão de tempo “Or”. Após refletir sobre a analogia das imagens vistas (giesta solitária no vulcão e no campo), o poeta considera essa flor como sendo amante do deserto, dos lugares tristes e inabitados. Portanto companheira de uma sina devastadora.

\section{Segunda parte: “A natureza" vv. 17 - 86}

Nesta segunda parte do poema, tem-se a presença da natureza como força devastadora e dominante. O poeta descreve os efeitos causados pela "dura nutrice" com um tom irônico, dirigindo-se àqueles que tanto exaltam a condição humana sem enxergar a pouca consideração que a natureza tem pelas espécies vivas. Será também direcionada a crítica do poeta ao século XIX, com sua filosofia otimista e ilusória, recusando-se a acreditar na má sorte destinada às espécies.

Questi campi cosparsi

Di ceneri infeconde, e ricoperti

Dell'impietrata lava,

20 Che sotto i passi al peregrin risona;

Dove s'annida e si contorce al sole

La serpe, e dove al noto

Cavernoso covil torna il coniglio;

Fur liete ville e colti,

25 E biondeggiàr di spiche, e risonaro

Di muggito d'armenti;

Fur giardini e palagi,

Agli ozi de' potenti

Gradito ospizio; e fur città famose,

30 Che coi torrenti suoi l'altero monte
Estes campos regados

De cinzas infecundas, recobertos

De lava feita em pedras

Que ecoa quando a pisa o peregrino;

Onde se aninha e se retorce ao sol

A serpente, e onde ao velho

Cavernoso covil retorna o coelho;

Foram vilas, cultivos

E lourejar de espigas, e onde ecoaram

Mugidos de rebanhos;

Foram jardins, palácios,

Do ócio de poderosos

Aprazível refúgio; e até cidades

Que com torrentes o altaneiro monte 
Dall'ignea bocca fulminando oppresse Con gli abitanti insieme. Or tutto intorno
De boca em fogo fulminou destruindo-as E aos habitantes junto. Agora a tudo

A segunda parte abre-se com um olhar do poeta voltado ao presente. Hoje os campos vesuvianos estão regados por cinzas estéreis e encobertos por lava petrificada, que ecoa sob os passos do viajante. Trata-se, então, de um local não adequado para se viver. A presença de serpentes que se contorcem ao sol e de coelhos selvagens que voltam aos covis demonstra a característica do ambiente: inabitável.

Nota-se a presença das sibilantes/s/ nos versos 21 e 22, "Dove s'annida e si contorce al sole" - "La serpe, e dove al noto", no momento em que o poeta identifica a presença da serpente, quase que para criar um efeito onomatopeico do sibilar do animal. Da mesma forma, a repetição da oclusiva $/ \mathrm{k} /$, juntamente com a vogal arredondada /o/ no verso 22, "Cavernós $\underline{\text { co }}$ vil torna il coniglion", criam um efeito de algo sombrio e escondido, assim como vem descrito o covil do coelho. Na tradução brasileira, ambos os efeitos foram mantidos: "Onde se aninha e se retorce ao sol -A serpente, e onde ao velho" e "Cavernos $\underline{o}$ covil retorna o coelho"

Todavia, nem sempre foi assim esse ambiente. $\mathrm{O}$ poeta, com uma rápida mudança volta seu olhar ao passado. Percebe-se a mudança dos tempos verbais: "fur - biondeggiàr - risonaro fur - fur", do presente para o "passato remoto", indicando a existência anterior de vilas, campos cultivados, plantações de milho, criação de gado, jardins, palácios, ou seja, um lugar perfeito para o lazer dos ricos habitantes da época.

É notável a mudança de tom na passagem dos versos 24 ao 29. Tratando-se de uma descrição de um ambiente que já foi agradável aos homens poderosos, o tom torna-se mais saudosista. $\mathrm{O}$ ritmo fica mais lento, devido à presença de pontuação e da repetição polissindética da conjunção "e", enquanto a assonância nas vogais claras ${ }^{130} / \mathrm{e} / \mathrm{-li} /$, rendem a descrição mais leve: "Fur liete ville e colti, / E biondeggiàr di spiche, e risonaro / Di muggito d'armenti; / Fur giardini e palagi, / Agli ozi de ' potenti / Gradito ospizio; e fur città famose,".

\footnotetext{
${ }^{130}$ De acordo com a teoria de Grammont, In: Candido, A. 1986, p. 54
} 
Lá onde surgiram cidades famosas, hoje não resta mais nada, pois o majestoso monte, com sua boca de fogo, expeliu lava esmagando-as, juntamente com a aniquilação de sua população. A velocidade do período é dada devido à ausência de pontuação nos versos 30 a 32, demonstrando com quão voracidade a lava destruiu tudo.

Agora, nos lugares onde está a giesta, avistam-se somente ruínas. E como que para servir de alívio ao ambiente, ali está a gentil e perfumada giesta; embelezando com a sua presença a cruel paisagem e exalando o seu perfume para suavizar a terrível devastação do ambiente.

Con gli abitanti insieme. Or tutto intorno Una ruina involve, Dove tu siedi, o fior gentile, e quasi

35 I danni altrui commiserando, al cielo Di dolcissimo odor mandi un profumo, Che il deserto consola. A queste piagge Venga colui che d'esaltar con lode Il nostro stato ha in uso, e vegga quanto

40 È il gener nostro in cura

All'amante natura. E la possanza

Qui con giusta misura

Anco estimar potrà dell'uman seme,

Cui la dura nutrice, ov'ei men teme,

45 Con lieve moto in un momento annulla

In parte, e può con moti

Poco men lievi ancor subitamente

Annichilare in tutto.

Dipinte in queste rive

50 Son dell'umana gente

Le magnifiche sorti e progressive.
E aos habitantes junto. Agora a tudo

Uma ruína envolve,

Onde tu pousas, flor gentil, e como

Que os danos de outros deplorando, ao céu

De dulcíssimo odor dás um perfume

Que consola o deserto. A estas plagas

Acorra aquele que a exaltar com loas

A nossa condição, constate quanto

A espécie nossa é presa

À amante natureza. E o poder todo

Que com justa clareza

Poderá estimar da humana raça

O que a dura nutriz, sem ameaça,

Com leves baques num momento anula

Em parte, e em movimentos

Menos leves então subitamente

Reduz em pouco a nada.

Aqui pintados, vivos,

Estão da humana gente

Destinos de grandeza e progressivos.

A partir do verso 37, o poeta faz uma longa digressão, voltando-se contra a natureza e seu falso progressismo. Aquele que exalta, com tanto louvor, a condição humana, é convidado pelo poeta a visitar esses locais tão desolados. Deste modo poderá perceber nitidamente a "grande" consideração que a natureza tem para com a raça humana.

Interessante é a escolha do substantivo "piagge" no verso 37, indicando lugares em declive, em decadência. É possível fazer uma relação deste termo com uma palavra italiana: "piaghe" (pragas), tendo no sentido figurado o significado de destruição, flagelo ou danos. Assim 
sendo, o leitor pode associá-las à imagem tão impressionante que há diante de si: a área ao redor do Vesúvio. O mesmo jogo é mantido na tradução brasileira, pois a expressão "piagge" foi traduzida por "plagas", que por sua vez lembra "pragas".

O uso dos verbos no imperativo "Venga - vegga", que ecoam ao ser pronunciados, dá um tom forte ao período. Desta forma, o poeta tenta chamar atenção deste homem sonhador para a realidade dos fatos. Para isso faz uso da ironia, principalmente nos versos 40 e 41, "É il gener nostro in cura / All'amante natura. E la possanza", demonstrando a atenção que a amada natureza reserva à espécie humana. Tal ironia vem realçada pela presença da rima, no meio do verso, entre as palavras “cura-natura”. Fica claro ao leitor que a natureza não tem estima pela raça humana, portanto, afirmar que ela é amena, acentua a ironia do período. Affonso Félix de Sousa manteve em sua tradução a presença dos verbos no imperativo "Acorra - constate", mas a presença da ironia foi atenuada pela explicitação, pois o tradutor deixa bem claro, graças à rima "presa - natureza", o cruel papel da amante natureza: o de tornar o ser humano uma de suas vítimas.

Este homem tolo, não temente à natureza, é convidado pelo poeta a avaliar a potência da natureza, a qual com o mínimo esforço, em um instante, anula parcialmente tudo. Para isso, lhe basta causar um leve tremor de terra, já que lhe é suficiente um movimento um pouco menos leve para conseguir aniquilar todas coisas que a própria criou.

A escolha das expressões presentes nos versos 43 e 44: "dell'uman seme / ov'ei men teme”, parece ser proposital, já que a rima sugere o caráter incrédulo da raça humana, a qual não percebe o caráter cruel da natureza.

Interessante é também a presença das antíteses nesse período "dura-lieve”. A natureza é dura e utiliza-se de leves movimentos para acabar com tudo. "Dura nutrice" porque não há respeito pelas coisas consideradas sacras pela raça humana, enquanto "lievi moti" porque diante da ordem universal é mínima a força aplicada pela natureza para exterminar aquilo que está ligado aos homens, inclusive os próprios seres da raça humana. 
A conclusão dessa primeira estrofe é um tanto irônica, pois a paisagem que o poeta descreve em volta do Vesúvio representa o destino da raça humana. Para retratar tal mensagem, ele utiliza, em sentido negativo, as palavras de outro escritor, como é possível verificar no verso 51 "Le magnifiche sorti e progressive”. Essa definição é de autoria do escritor Terenzio Mamiani, primo de Leopardi, presente em uma dedicatória de seus Inni sacri (1832), que traz as seguintes palavras, com tom otimista: "la vita civile comincia dalla religione" e nós "uguali e Fratelli" somos chamados "a condurre ad effetto com savia reciprocanza di virtù e di fatiche le sorti magnifiche e progressive dell'umanità ${ }^{, 131}$.

O poeta deixa evidente a sua ironia ao inverter a ordem das palavras, criando assim um jogo antitético, graças também à rima presente nos versos 49 e 51, "rive - progressive”, pondo assim em contraste o local devastado com o destino marcado pelo progresso dos homens. Fica claro, portanto, o porquê da expressão estar grafada em itálico no corpo do poema, em se tratando de "parole di um moderno, al quale è dovuta tutta la loro eleganza 132 ", como o próprio Leopardi frisa em uma de suas notas.

A segunda estrofe do poema continua abordando o tema da natureza, vista sempre como superior ao homem, mas o trecho também traz a crítica leopardiana contra o século altivo e tolo. Percebe-se uma negatividade do poeta no confronto do século XIX, considerando-o como um período fraco de sabedoria. Não é com a arma do progresso e da técnica, muito menos com o espiritualismo, encarado como uma volta ao pensamento religioso medieval, que o homem mostrar-se-á mais forte contra os elementos naturais.

Qui mira e qui ti specchia,

Secol superbo e sciocco,

Che il calle insino allora

55 Dal risorto pensier segnato innanti

Abbandonasti, e volti addietro i passi, Del ritornar ti vanti, E procedere il chiami.
Aqui olha e te espelha, Século altivo e tolo, Que o atalho até então Ao pensamento assinalado antes Abandonaste, e atrás voltando os passos, Do retorno te ufanas E de progresso o chamas.

\footnotetext{
${ }^{131}$ LEOPARDI, G. Canti. Org. Lucio Felice, Roma: Newton \& Compton editori, 1999, Nota 51, p.216. "a vida civil começa pela religião" e nós "iguais e Irmãos" somos chamados "a levar a efeito, com sábia reciprocidade de virtudes e de esforços a destinos magníficos e progressivos da humanidade."- [Trad. nossa]

132 "palavras de um moderno, ao qual é devida toda elegância delas" - [Trad. nossa]
} 
Neste primeiro período da segunda estrofe, o poeta faz um convite ao homem de seu século para que ele observe as encostas do vulcão e se espelhe nelas. Desta forma poderá conhecer a cruel, mas real, sina em que vai ao encontro a raça humana. Nota-se a insistência do advérbio de lugar "qui", colocado duas vezes no mesmo verso. Tal eco serve para chamar a atenção do vocativo em questão, no verso 53 "Secol superbo e sciocco", além de reforçar o tom de irritação do poeta. A presença de vogais sombrias ${ }^{133} / \mathrm{o} / \mathrm{e} / \mathrm{u} /$, ajudam a criar a sensação de desaponto. O século em questão é considerado “superbo" porque adquiriu certezas filosóficas que para o poeta são ilusórias e é “sciocco”, pois tais ilusões são tidas como realidade.

O século XIX vem acusado de ter abandonado e retrocedido o caminho até então traçado, o qual é feito de um progresso considerado verdadeiro pela filosofia renascentista e retomado pela corrente iluminista. Walter Binni explica essa passagem da seguinte forma:

Il pensiero risorto è quello razionalistico e sensistico dal Rinascimento in poi e il regresso dell'Ottocento sarebbe il suo spiritualismo, il ritorno al pensiero religioso medioevale. E qui si tenga presente che l'informazione del Leopardi sul pensiero contemporaneo era scarsa e soprattutto vaghissima quella sul grande idealismo tedesco che egli quasi del tutto ignorò. Ciò che più doveva nausearlo era la volgarizzazione dello spiritualismo romantico nelle riviste e nei libri di filosofi ben poco profondi. Ciò che lo colpiva era la tendenza generale più che altro avvertita nelle conversazioni e in assaggi culturali limitati. ${ }^{134}$

Al tuo pargoleggiar gl'ingegni tutti,

60 Di cui lor sorte rea padre ti fece

Vanno adulando, ancora

Ch'a ludibrio talora

T'abbian fra se. Non io

Con tal vergogna scenderò sotterra;

65 Ma il disprezzo piuttosto che si serra

Di te nel petto mio,

Mostrato avrò quanto si possa aperto:

Ben ch'io sappia che obblio

Preme di troppo all'età propria increbbe.
A teu infantilismo esses engenhos, De cujo malefício pai te fez

Vão adulando, embora

Com ludíbrio talvez

Dentro de si. Não eu:

Vergonha tal não terei sob a terra,

Sem que o grande desprezo que se encerra

Por ti no peito meu

Eu mostre o mais que possa abertamente:

Sabendo bem que o olvido

Oprime quem lamenta a própria época.

\footnotetext{
${ }^{133}$ De acordo com a teoria de Grammont, In: Candido, A. 1986, p. 54

${ }^{134}$ LEOPARDI, G. Canti. Org. Lucio Felice, Roma: Newton \& Compton editori, 1999, Nota 54-56, p.216. "O pensamento ressurgido é aquele racionalista e sensista do Renascimento em diante e o regresso do Oitocentos seria o seu espiritualismo, a volta do pensamento religioso medieval. E aqui se deve considerar que a informação que Leopardi tinha sobre o pensamento contemporâneo era escassa e principalmente muito vaga sobre o grande idealismo alemão, o qual ele quase ignorou completamente. Aquilo que mais deveria nauseá-lo era a vulgarização do espiritualismo romântico nas revistas e nos livros de filosofia - bem pouco profundos. O que chamava a sua atenção era a tendência geral notada nas conversações e nos exercícios culturais limitados." - [Trad. nossa]
} 
Neste período, o poeta, com um sarcasmo violento, dirige-se aos doutos, nascidos no século XIX por vontade de sua inimiga sorte. Esses, aparentemente, adulam a filosofia ilusória, otimista e espiritualista da época, mas, por outro lado, no fundo de seus corações, caçoam dela. Portanto, fica clara a posição hipócrita dos homens de engenhos, demonstrando-se insinceros.

Interessante é a escolha do verbo "pargoleggiar" (comportamento típico infantil), pois marca o contraste existente entre os homens maduros, por conta dos estudos, que seguem adulando o infantilismo deste século. Distanciado desses doutos está o poeta. Ele não se rebaixará a seguir semelhante comportamento, o qual lhe causaria somente vergonha, mas, de forma sincera e clara, mostrará o seu desprezo para com essa nova ideia ilusória do século. Nota-se o contraste entre o caráter camuflado dos engenhos e a franqueza do poeta - "Ch'a ludibrio talora / T'abbian fra se. Non io " e "Ma il disprezzo ... / ... Mostrato avrò quanto si possa aperto:". O mesmo contraste foi reproduzido na tradução brasileira, “Com ludíbrio talvez, / Dentro de si. Não eu:” e “...o desprezo... / Eu mostre o mais que possa abertamente:"

Mesmo o poeta sabendo que quem não estivesse de acordo com a ideologia da época seria destinado ao esquecimento, ele segue orgulhoso o seu caminho, sem inclinar-se. Define, portanto, a glória como o reconhecimento dos homens para com os seus semelhantes; mas para o poeta, tal sentimento de glória é inútil, conforme explicará mais adiante.

Esse caráter decidido vem marcado pela presença da assonância da vogal /e/, nas seguintes expressões: "diprezzo, che si serra, di te, nel petto mio, aperto". Assim como a rima, as palavras "io" - "mio" - "obblio" põem em evidência o caráter subjetivo e batalhador do poeta. A assonância também está presente na tradução brasileira, bem como a rima "eu - meu", separando, porém, a palavra "olvido - obblio" da rima.

A escolha das expressões "sotterra" - "si serra", que são acopladas pela rima, acentua a dramatização e o tom enérgico dos versos, visto que o poeta tem consciência de estar pronunciando as suas últimas palavras. Tal recurso é bem recriado na tradução brasileira: "sob $a$ terra / se encerra". 
70 Di questo mal, che teco

Mi fia comune, assai finor mi rido.

Libertà vai sognando, e servo a un tempo

Vuoi di nuovo il pensiero,

Sol per cui risorgemmo

75 Della barbarie in parte, e per cui solo

Si cresce in civiltà, che sola in meglio

Guida i pubblici fati.

Così ti spiacque il vero

Dell'aspra sorte e del depresso loco

80 Che natura ci diè. Per questo il tergo

Vigliaccamente rivolgesti al lume

Che il fe palese: e, fuggitivo, appelli

Vil chi lui segue, e solo

Magnanimo colui

85 Che se schernendo o gli altri, astuto o folle, Fin sopra gli astri il mortal grado estolle.
É mal comum a nós

Do qual me rio muito até agora.

Liberdade sonhando, e servo a um tempo

Queres o pensamento

Pelo qual ressurgimos

Nós da barbárie, e pelo qual se cresce

Em civilização, a que melhor pode

Guiar os feitos públicos.

Assim doeu-te a verdade

Da sorte áspera e ínfima paragem

Destinadas a ti. Por isso o dorso

Covardemente dirigiste à luz

Que o revelou: e fugitivo chamas

De vil a quem o segue

E magnânimo aquele

Que a rir de si e de outros, fino ou louco, Aos astros o mortal eleva em troco.

O poeta sabe que é destinado ao total esquecimento, assim como o próprio século também não fugirá de tal sina. Inicia, desde agora, a rir deste mal que afligirá a todos, pois a glória otimista do século em questão não será imortal, assim como o próprio poeta.

Contraditória é a filosofia do século XIX, pois ao mesmo tempo em que dá ao homem a ilusão de uma suposta liberdade (política) e felicidade, também o aprisiona a certos dogmas pensamentos ligados a superstições medievais do tipo social e religioso. Tal contradição vem marcada no verso 72, dividido em duas partes, devido à presença da vírgula. Nota-se a presença de uma antítese entre as palavras: "libertà" e "servo", e "liberdade" e "servo" na tradução brasileira, marcando o caráter contraditório deste século, conforme explicado acima.

Para o poeta, somente foi possível superar a "barbárie" medieval por meio do pensamento racional-humanista que a sucedeu. Sendo assim, critica o seu século por voltar a acreditar nos dogmas religiosos, assim como no medievo, e por pensar que será somente graças à civilização que o homem poderá ir ao encontro da melhora de sua sorte. É importante frisar a presença da expressão "in parte" referindo-se à parcial superação das barbáries medievais, pois ainda se têm resíduos dela no século XIX. 
Novamente o poeta faz menção à natureza devastadora, tendo a filosofia moderna mostrado ao homem a sua real posição de inferioridade perante a natureza universal. Desta forma os pensadores oitocentistas rejeitaram, de modo covarde, tal visão iluminista, preferindo ilusoriamente viver no passado supersticioso do medievo.

Na filosofia moderna levam-se em consideração os princípios da filosofia iluminista do Seiscentos, com raízes nas teorias de Copérnico, o qual renovou a relação da natureza com homem, conscientizando-o à sua condição humilde perante dela.

No último período da estrofe em questão, o poeta continua direcionando-se à filosofia de seu século, considerando-a covarde por ter preferido dar as costas àquela doutrina (Iluminismo) que havia revelado a real situação do homem: seu duro destino e situação de inferioridade. Todavia, contraditoriamente, essa filosofia atual considerava vil aquele que persistia em seguir o pensamento iluminista enquanto louvava àquele que se recusava em acreditar na própria infelicidade. Acreditando ser, esse último, superior às demais espécies, ele pensa que lhe está reservado um destino celestial. Interessante é a rima presente nos dois últimos versos dessa estrofe: "folle - estolle”. Pois aquele que acreditar gozar de uma posição elevada em relação às demais espécies é considerado louco. A rima "louco - troco" na tradução brasileira faz referência àquilo que o homem almeja ao seguir o pensamento de seu século: ele seria um louco em exigir um troco, o qual é representado pela sua exaltação, além da condição humana.

\section{Terceira parte: “O homem" vv. $87-201$}

Esta terceira parte do poema dedica-se à presença do homem. Vem aqui demonstrada a existência de dois tipos de homem: o pouco inteligente e o rico em nobreza.

Uom di povero stato e membra inferme

Che sia dell'alma generoso ed alto, Non chiama se né stima

90 Ricco d'or né gagliardo, E di splendida vita o di valente Persona infra la gente Non fa risibil mostra; Ma se di forza e di tesor mendico
O homem que é pobre e tem o corpo enfermo, Contudo de alma generoso e nobre, Não se diz nem se estima Rico em ouro e galhardo, E de esplêndida vida ou de valente Pessoa em meio à gente Não faz visível mostra; Mas se de bens e de vigor mendigo 
95 Lascia parer senza vergogna, e norma Parlando, apertamente, e di sue cose Fa stima al vero uguale.

\section{Magnanimo animale}

Non credo io già, ma stolto,

100Quel che nato a perir, nutrito in pene,

Dice, a goder son fatto,

E di fetido orgoglio

Empie le carte, eccelsi fati e nove

Felicità, quali il ciel tutto ignora,

105 Non pur quest'orbe, promettendo in terra

A popoli che un'onda

Di mar commosso, un fiato

D'aura maligna, un sotterraneo crollo

Distrugge sì, ch'avanza

110A gran pena di lor la rimembranza.
Se diz sem se vexar, e isto declara

Falando abertamente, a suas coisas

Dá o valor legal.

Magnânimo animal

Não creio já, mas tolo,

Quem nascido mortal, de dor nutrido,

Diz: para gozar fui feito,

E de um abjeto orgulho

Enche os papéis, excelsos fados, novas

Felicidades, que no céu se ignora,

Mas este mundo, a prometer na terra

A povos que uma onda

De mar movido, um sopro

De aura maligna, um subterrâneo abalo

Tanto destrói que apenas

Deles fica a lembrança a duras penas.

A estrofe abre-se com a descrição de um homem pobre e enfermo, mas rico em bondade e generosidade. Desta forma não é vergonha ou sinal de fraqueza assumir a própria condição de infelicidade e de inferioridade; pelo contrário, vem considerado ridículo aquele que, diante de sua condição precária, continua fingindo ter, por soberbia, um destino promissor e feliz a sua espera.

Segundo o crítico Francesco Biondolillo os versos 87 e 88 referem-se à crítica leopardiana para aqueles que atribuem a derivação de seu pensamento pessimista unicamente à sua condição de enfermidade. Assim Biondolillo diz:

"Che il Leopardi intendesse, in questi due versi, riferirsi a se stesso, è evidente: egli protesto sempre che il suo pessimismo derivasse dal suo 'povero stato' e dalle sue 'membra inferme', ma, piuttosto, dalla forza del suo animo che gli consentiva di guardare con stoica austerità alla infelicità sua e dell'umanità in generale ${ }^{135,}$.

O segundo período da estrofe abre-se com ironia. O homem vem aqui considerado como "Magnanimo animale” e por mais que todos os seres animados sejam considerados iguais, ou seja, animais, é ilógico da parte do homem considerar-se magnânimo.

\footnotetext{
${ }^{135}$ BIONDOLILLO, 1952, p. 316 - nota 87-8.
}

"Que Leopardi, nesses dois versos, referia-se a si próprio, é evidente: ele sempre negou que o seu pessimismo derivasse do seu 'pobre estado' e dos seus 'membros enfermos', pelo contrário, [derivava] da força de seu ânimo que lhe consentia em observar com estoica austeridade a infelicidade própria e humana em geral.” - [Trad. nossa] 
Desta forma aquele que se define superior às demais espécies vem aqui considerado tolo, visto que continua acreditando ser destinado à felicidade enquanto se sabe ter nascido para padecer e morrer. Todavia, tal crença vem facilmente considerada ilusória, visto que jamais alguém na Terra ou no universo já provou de tal felicidade. "Nato a perir" é uma expressão particularmente curiosa, pois o autor poderia ter utilizado o adjetivo "mortal", como na tradução brasileira "nascido mortal", mas, ao escolher "perir" criou um efeito mais alongado, para demonstrar que o homem nasceu para sofrer constante pena e assim ser destruído.

Para demonstrar a pequenez da raça humana, o sujeito-lírico descreve com quanta facilidade a natureza extermina tudo; basta-lhe para isso provocar um maremoto, uma peste ou até mesmo um terremoto que do homem restará somente a lembrança.

Nota-se o cuidado seletivo das expressões presentes nos versos 107 e 108, criando um efeito onomatopeico devido às assonâncias e as aliterações nelas presentes. Em "mar commosso", as aliterações nas consoantes bilabiais /m/ e nas sibilantes /s/ lembram o barulho das ondas subindo e quebrando-se no mar devido à fúria do vento, assim como a aliteração em /m/ mantida na tradução brasileira "mar movido". Em "un fiato d'aura maligna" a presença das assonâncias /a/ combinadas com as semivogais /i/ e /u/ cria o efeito de um sopro quente alongado de mau augúrio, efeito também mantido na tradução brasileira "um sopro de aura maligna". Assim como em "un sotterraneo crollo", são as aliterações em /r/, /t/ e /l/ que sugerem o tremor e o rolar da terra, simulando um terremoto; tais consoantes são também mantidas na tradução brasileira: "um subterrâneo abalo".

Nobil natura è quella

Che a sollevar s'ardisce

Gli occhi mortali incontra

Al comun fato, e che con franca lingua, 115Nulla al ver detraendo,

Confessa il mal che ci fu dato in sorte,

E il basso stato e frale;

Quella che grande e forte

Mostra se nel soffrir, né gli odii e l'ire

120Fraterne, ancor più gravi

D’ogni altro danno, accresce

Alle miserie sue, l'uomo incolpando

Del suo dolor, ma dà la colpa a quella
Que nobre natureza

Essa que a erguer se atreve

Os olhos mortais contra

O comum fado, e que com franca língua

Dizendo só verdades

Confessa o mal a nós dado por sorte,

E o baixo estado e o frágil;

Essa que grande e forte

Mostrar-se no sofrer, sem ódios e iras

Fraternas, bem mais graves

Que qualquer dano junta

Às misérias que sofre, o homem culpado

Por sua dor, mas não culpando aquela 
Che veramente è rea, che de' ortali 125Madre è di parto e di voler matrigna.
Que na verdade é ré, e dos mortais

Mãe é no parto e no querer madrasta.

Neste período tem-se a moral da temática leopardiana: o homem deve lutar heroicamente contra o seu destino, enfrentando-o e suportando suas dores. Portanto, aquele mortal que tenha tamanha coragem, conseguindo encarar o real destino dos seres viventes, será considerado de alma nobre. O poeta, sem fingimento, à diferença dos pensadores de sua época, não atenua em nada a verdade e admite a sua condição submissa de pobre mortal, encarando a sua má ventura.

Contraditoriamente, utilizam-se, nos versos 117 e 118, expressões antitéticas: "basso frale - grande - forte", as quais são também mantidas na tradução brasileira "baixo - frágil grande - forte". Ressalta-se, assim, o contraste existente entre o homem comum e o homem magnânimo que enfrenta a sua vida bravamente, sem provar ira ou ódio contra seus irmãos, pois esses, assim como é comum para todos os mortais, já possuem uma vida de sofrimento.

Não é ao homem que se deve culpar por tamanha desventura, mas é necessário dar a culpa à verdadeira causadora da dor: a natureza, mãe dos mortais no parto e madrasta por vontade. Nota-se que no verso 125, tem-se um quiasmo: "Madre è di parto e di voler matrigna." que sugere o caráter contraditório da natureza, o quiasmo é também reproduzido na tradução brasileira: "Mãe é no parto e no querer madrasta".

Costei chiama inimica; e incontro a questa Congiunta esser pensando,

Siccome è il vero, ed ordinata in pria

L'umana compagnia,

130Tutti fra se confederati estima

Gli uomini, e tutti abbraccia

Con vero amor, porgendo

Valida e pronta ed aspettando aita

Negli alterni perigli e nelle angosce

135Della guerra comune. Ed alle offese

Dell'uomo armar la destra, e laccio porre

Al vicino ed inciampo,

Stolto crede così qual fora in campo

Cinto d'oste contraria, in sul più vivo

140Incalzar degli assalti,

Gl'inimici obbliando, acerbe gare

Imprender con gli amici,
A esta chama inimiga, e contra ela

Crendo estar coligada,

Como está, e ordenada desde sempre

A humana companhia,

Como entre si confederados julga

Os homens e os abraça

Com amor, ofertando

E esperando vital e pronta ajuda

Nos perigos diversos e na angústia

Da guerra que sustentam. E às ofensas

Do homem armar a destra e estender laços

E óbices ao vizinho,

Estulto crê assim como em caminho

Cheio de hostes contrárias, no mais vivo

Acossar dos assaltos,

Inimigos largando, acerbas brigas

Tendo com os amigos, 
E sparger fuga e fulminar col brando Infra i propri guerrieri.
Correr como a fugir brandindo espadas

Contra os próprios guerreiros.

O homem nobre de espírito chama, então, como sua real inimiga a natureza. Para o poeta, desde os primórdios, a sociedade organizou-se contra esse mal comum; dessa mesma forma, o homem deveria continuar a se unir, garantindo, assim, apoio mútuo nas horas de necessidade e de angústia contra uma guerra em comum.

Aquele que se arma para atacar seu próprio irmão, ou para assediar seu vizinho, é aqui considerado um tolo. Muito jocosa é a comparação feita nos versos seguintes: persistir nesse comportamento é tão absurdo como esquecer a presença do inimigo, tendo ele acampamento rodeado pelo exército antagonista. Assim como seria injusto atacar o próprio batalhão em pleno assalto inimigo, causando assim, a fuga dos companheiros. Até mesmo o ritmo dos versos em questão torna-se mais leve ao descrever tamanha contradição, indicando a insanidade do homem.

145 Così fatti pensieri

Quando fien, come fur, palesi al volgo,

E quell'orror che primo

Contra l'empia natura

Strinse i mortali in social catena,

150Fia ricondotto in parte

Da verace saper, l'onesto e il retto

Conversar cittadino,

E giustizia e pietade, altra radice

Avranno allor che non superbe fole,

155 Ove fondata probità del volgo

Così star suole in piede

Quale star può quel ch'ha in error la sede.
Tais fatos, quando inteiros

Deles souber, e de outros mais, o vulgo,

$E$ aquele horror que outrora

Contra a má natureza

Constrangeu os mortais numa cadeia,

Se recupere em parte

Pelo vero saber, o honesto e reto

Consórcio citadino,

E justiça e piedade outra raiz

Terão então, não as soberbas crenças

Em que baseia o vulgo a probidade

Como tem seu sustento

Aquele que conserva no erro o assento.

Somente quando os ideais da união fraternal e da aversão à natureza estiverem ao conhecimento de todos, como já ocorreu há um tempo, a honestidade, a retidão, a justiça e a piedade poderão ter bases bem mais sólidas do que as crenças soberbas alicerçadas no erro. Fica clara aqui a crítica ao século XIX, o qual, com suas ideologias otimistas, se fundamenta em ilusões antropocêntricas e religiosas.

Termina aqui o longo raciocinar do poeta em tom polemizado. Curioso é perceber que a moral temática leopardiana está localizada num posicionamento central do poema (O homem), 
conforme as subdivisões proposta nesta análise. Um famoso estudioso da estilística literária, Leo Spitzer (1955, p.136), já se perguntava se o desvio de uma obra (um elemento que tenha chamado a atenção no texto) coordena-se com os demais elementos do texto, formando assim um sistema. Se assim for, Spitzer acredita que um singular desvio pode levar ao centro da obra, como se pertencesse, por exemplo, a um sistema solar. Para comprovar se o desvio encontrado, por meio do subjetivismo, é significativo, Spitzer sugere aplicar o assim chamado círculo filológico: ciclo de leituras, avançando ou retrocedendo, relacionando o todo com a parte. Ao analisar o poema no seu todo, percebe-se que um detalhe está interligado a outro, conduzindo à moral temática leopardiana, posicionada no centro do sistema.

Com a segunda estrofe dessa terceira parte do poema, surgem, novamente, as imagens líricas. O poeta volta sua atenção à encosta do Vesúvio e começa a observar o espetáculo ao seu redor.

Sovente in queste rive,

Che, desolate, a bruno

160 Veste il flutto indurato, e par che ondeggi,

Seggo la notte; e su la mesta landa

In purissimo azzurro

Veggo dall'alto fiammeggiar le stelle,

Cui di lontan fa specchio

165 Il mare, e tutto di scintille in giro

Per lo vòto seren brillare il mondo.
Não raro nesta plaga,

Que, desoladas, veste

De escuro a lava, e que, parece, ondeiam,

Sento-me à noite; e sobre a erma charneca

Em puríssimo azul

Contemplo no alto o flamejar de estrelas,

Às quais serve de espelho

O mar, e de cintilações em torno

Faz no ar sereno reluzir o mundo.

Sentado nas vertentes do vulcão, vestido de lava escura endurecida, que ainda conserva a sua forma de onda de quando escorreu incandescente, o poeta observa a noite. Deste lugar esquálido e deserto, contempla o céu em seu esplendido azul, com estrelas flamejantes, servindolhes o mar de espelho. Tudo cintila pelos espaços vazios, ao redor da imensidão do céu.

Interessante é notar que tudo está, em harmonia lá no céu, segundo a visão humana, enquanto a Terra, representada pela encosta do Vesúvio, está infeliz e abandonada, ficando, assim, sem ser escutada pelo céu. Percebe-se que nos versos 165 e 166, tem-se o jogo de assonância agudas em /i/, “di scintille in giro - brillare il mondo”, enquanto que nos versos 159 e 160, predomina a assonância sombria em /o/ e /u/, “desolate, a bruno - Veste il flutto 
indurato". Desta forma tem-se o contraste do céu e da terra. Por mais que na tradução de Affonso Félix de Sousa exista a presença das assonâncias agudas "de cintilações - reluzir" e sombrias “desoladas - de escuro", o efeito criado não parece ser tão intenso quanto nos versos de Leopardi.

No verso 161, tem-se uma pausa significativa, marcada pela presença de um ponto-evírgula, o que cria uma atmosfera de meditação relevante, acentuando a solidão do sujeito que observa a cena.

Os períodos que seguem são bastante curiosos, visto que dois deles são longuíssimos, compostos de dezenove e dezesseis versos, enquanto o último que encerra a estrofe é formado de somente um verso.

Os dois períodos mais complexos têm estrutura parecida. Ambos são interrogativos, formados por três orações, separados por ponto e vírgula (vv. 171 - 174 e 183), que antecipam a oração principal, localizada no final do período. Tal estrutura pode criar um ar pesado durante a leitura, mas por outro lado representa a grandiosidade do espetáculo descrito, ao mesmo tempo em que demonstra a crescente soberba humana.

E poi che gli occhi a quelle luci appunto,

Ch'a lor sembrano un punto,

E sono immense, in guisa

170 Che un punto a petto a lor son terra e mare

Veracemente; / a cui

L'uomo non pur, ma questo

Globo ove l'uomo è nulla, Sconosciuto è del tutto; / e quando miro

175 Quegli ancor più senz'alcun fin remoti

Nodi quasi di stelle,

Ch'a noi paion qual sabbia, a cui non l'uomo

E non la terra sol, ma tutte in uno,

Del numero infinite e della mole,

180 Con l'aureo sole insiem, le nostre stelle

O sono ignote, o così paion come

Essi alla terra, un punto

Di luce nebulosa; / al pensier mio

Che sembri allora, o prole

185 Dell'uomo? E rimembrando
Se os olhos para as luzes eu aponto

Parecem-lhes um ponto,

E são imensas, tanto

Que, comparado, um ponto são a terra

E o mar, é fato; / e o homem,

Não só ele, mas este

Globo onde o homem é nada,

Desconhecido é todo; / e quando miro

Aqueles mais remotos, infinitos

E quase nós de estrelas,

Que nos parecem névoa, aos quais não o homem

E não a terra só, mas eles todos,

De número infinito, juntamente

Com o áureo sol também,

Ou são ignotas, ou assim nos lembram

Elas a terra, um ponto

De nebulosa luz; / ao pensar meu

O que és então, ó raça

Do homem? E relembrando 
$\mathrm{Na}$ primeira divisão do período, nota-se que, com o olhar fixado às estrelas, o poeta começa a contemplá-las. Para o homem elas parecem pequenos pontos, enquanto que na realidade elas são enormes, tanto que, para as estrelas, a terra e o mar é que são somente pontos.

Já na segunda divisão, observa-se que para essas estrelas, não só o homem, o qual não é nada em si, mas também o globo terrestre passam totalmente despercebidos. Interessante é a rica presença da assonância das vogais /o/ e /u/ nos versos 172 a 174: "L'uomo non pur, ma questo / Globo ove l'uomo è nulla, / Sconosciuto è del tutto", dando um efeito sombrio e prolongado; a assonância em /o/ também foi recriada na tradução brasileira: "Globo onde o homem é nada, / Desconhecido é todo".

O poeta, na terceira divisão do período, observa as nebulosas distantes infinitamente da terra, tanto que elas lhe parecem uma névoa no céu; mas da mesma forma, o homem, a terra, todas as enormes e infinitas estrelas visíveis a ele e, até mesmo, o sol assemelham-se a um ponto para as nebulosas.

Sendo assim, na oração principal, o sujeito-lírico indaga-se retoricamente: que representará então a prole do homem diante de tamanha imensidão? A resposta a essa pergunta já foi dada no verso 173, “Globo ove l'uomo è nulla”, portanto, o homem não é nada.

185 Dell'uomo? E rimembrando

Il tuo stato quaggiù, di cui fa segno

Il suol ch'io premo; / e poi dall'altra parte,

Che te signora e fine

Credi tu data al Tutto, e quante volte

190 Favoleggiar ti piacque, in questo oscuro

Granel di sabbia, qual di terra ha nome,

Per tua cagion, dell'universe cose

Scender gli autori, e conversar sovente

Co' tuoi piacevolmente, / e che i derisi

195 Sogni rinnovellando, ai saggi insulta

Fin la presente età, che in conoscenza

Ed in civil costume

Sembra tutte avanzar; / qual moto allora,

Mortal prole infelice, o qual pensiero

200 Verso te finalmente il cor m'assale?

Non so se il riso o la pietà prevale.
Do homem? E relembrando

A tua condição, testemunhada

Pelo solo em que piso; / e, do outro lado,

Que tu senhora e fim

Te crês ao Todo dada, e quantas vezes

Te peço que fabules neste escuro

Grão de areia a que todos chamam terra

E que, por tua causa, do universo

Baixaram os autores e falaram

De bom grado com os teus, / e que ilusórios

Sonhos a renovar, insulta os sábios

Neste século que em conhecimentos

E cívico costume

Parece tudo superar; / que impulso, Mortal raça infeliz, que pensamento

Por ti então meu coração invade?

Não sei se é mais o riso ou a piedade. 
O segundo período, também dividido em três partes, mais a principal, direciona-se ao homem moderno, evidenciando, mais uma vez, a sua soberbia. Na primeira parte, o poeta faz lembrar ao ser humano a posição em que se encontra, fazendo um paralelo com a paisagem real onde o próprio poeta encontra-se: solo destruído - assim como o homem está destinado a ser pela natureza.

Continuando, na segunda divisão, vem demonstrada a presunção do homem e de sua prole, visto que ele se considera predestinado a dominar o universo. É tamanha a pretensão humana que ele imagina os deuses vindo a esse grãozinho de areia, chamado Terra, para conversar prazerosamente com os mortais.

Interessante é a inicial maiúscula da palavra "Tutto", traduzida também com a inicial maiúscula por "Todo", presente no verso 189, pois dessa forma a expressão ganha maior proporção, simbolizando o universo.

$\mathrm{Na}$ terceira parte, lembra-se também que a presente época, mesmo sendo supostamente superior às demais quanto ao saber e à civilização, renova as crenças religiosas - negadas pelos iluministas - insultando seus sábios.

Desta forma, o poeta indaga-se sobre que tipo de sentimento e de pensamento deveria ter em relação à mortal prole. Tratando-se também de uma pergunta retórica, tem-se logo a resposta no último período da estrofe analisada: "Non so se il riso o la pietà prevale”: o riso devido à soberbia humana, já a piedade por conta do trágico destino humano. Interessante é o uso do vocativo no verso 199 “Mortal prole infelice”, pois já se tem o sentimento dominante do poeta.

\section{Quarta parte: “A natureza” vv. 202-296}

Retorna-se aqui à temática já abordada nas partes analisadas, enfatizando a potência devastadora da natureza em relação aos seres vivos. 
Come d'arbor cadendo un picciol pomo,

Cui là nel tardo autunno

Maturità senz'altra forza atterra,

205 D'un popol di formiche i dolci alberghi,

Cavati in molle gleba

Con gran lavoro, e l'opre

E le ricchezze che adunate al tempo estivo,

Con lungo affaticar l'assidua gente

210 Avea provvidamente al tempo estivo,

Schiaccia, diserta e copre

In un punto; così d'alto piombando,

Dall'utero tonante

Scagliata al ciel profondo,

215 Di ceneri e di pomici e di sassi

Notte e ruina, infusa

Di bollenti ruscelli,

O pel montano fianco

Furiosa tra l'erba

220 Di liquefatti massi

E di metalli e d'infocata arena

Scendendo immensa piena,

Le cittadi che il mar là su l'estremo

Lido aspergea, confuse

225 E infranse e ricoperte

In pochi instanti: onde su quelle or pasce

La capra, e città nove

Sorgon dall'altra banda, a cui sgabello

Son le sepolte, e le prostrate mura

230 L'arduo monte al suo piè quasi calpesta.

Non ha natura al seme

Dell'uom più stima o cura

Ch'alla formica: a se più rara in quello

Che nell'altra è la strage,

235 Non avvien ciò d'altronde

Fuor che l'uom sue prosapie ha men feconde.
Qual da árvore ao cair pequeno pomo

Que pelo fim do outono

Sem outra força a madurez derruba,

Um formigueiro e os seus doces abrigos

Feitos na terra mole

Com persistência, e as obras

$\mathrm{E}$ as riquezas que com muita porfia

E um sem fim de fadiga a assídua gente

Havia no verão provisionado,

Esmaga, arrasa e cobre

Em pouco tempo; assim do alto atirando-se

Do útero trovejante

Lançada ao céu profundo,

De cinzas e de lavas e de pedras

Noite e ruína mista

De ferventes arroios,

Ou descendo a montanha

Com fúria em meio à relva

De rochas liquefeitas

E de metais e de abrasada areia

Baixando imensa cheia,

As cidades que o mar lá longe a praia

Banhava, confundiu,

Quebrou e recobriu

Num só instante: onde agora a cabra

Pasta, e cidades novas

Se fazem do outro lado, as sepultadas

Dando-lhes base, e os muros derrubados

$\mathrm{O}$ árduo monte a seus pés quase repisa.

Não tem a natureza

Mais cuidado com o homem

Do que com a formiga, e se mais raro é nela

Do que na outra o estrago,

Isto se dá, no fundo,

Em razão de o homem ser menos fecundo,

A estrofe abre-se com uma longa comparação, apresentando duas cenas: a destruição de um formigueiro por conta de uma maçã; e, em seguida, a erupção do Vesúvio que arrasa duas cidades construídas pelos homens. O formigueiro e as cidades representam o homem enquanto que a maçã e o vulcão simbolizam a natureza.

A imagem aqui criada é de uma maçã madura no fim do outono que, devido ao seu ciclo natural, cai de uma árvore, atingindo, assim, um formigueiro. $\mathrm{O}$ cair do pomo causa uma 
destruição total. Arrasa o que foi construído com tanto ardor pelas formiguinhas, atingindo e destruindo também, em um só instante, suas provisões recolhidas durante todo o período estivo.

Cuidadoso é o modo como vem descrito esse formigueiro. Para isso, faz-se uso de termos aplicados às coisas humanas, "dolci alberghi - molle gleba - gran lavoro - opre e ricchezze assídua gente", alguns termos também presentes na tradução brasileira "doces abrigos - com persistência - as obras e as riquezas - com muita porfia - assídua gente", ligam, assim, a formiga ao homem, do mesmo modo como estão relacionados seus destinos.

Da mesma forma, uma tenebrosa massa de lava, misturada com cinzas e pedras, desentranha-se do vulcão e é lançada ao céu profundo. Ela escorre ao longo das encostas do monte, como um rio em cheia, sob forma de um líquido incandescente de metais, pedras e areias destruindo, abatendo e sepultando, em poucos instantes, cidades que surgiam no mar, como Herculano e Pompeia.

A presença de expressões como "piombando - profondo - bollenti ruscelli - furiosa infocata", traduzidas em português por "atirando-se - profundo-ferventes arroios - com fúriaabrasada", dá maior dramaticidade à cena descrita, visto que são palavras bastante expressivas. Assim como a escolha da expressão "útero tonante" - "útero trovejante” também é bastante significativa, visto que, para o poeta, a terra é a mãe do homem, dessa forma imagina órgãos humanos na natureza.

A velocidade como a lava devasta o ambiente e vem bem marcada por uma série de recursos adotados pelo poeta ao longo dos versos. As enumerações presentes nos versos 211 "Schiaccia, diserta e copre”, 215 "di ceneri e di pomici e di sassi"; 220 e 221 "Di liquefatti massi, / E di metalli e d'infocata arena”, ajudam a criar uma rapidez sintática, recurso que é também bem mantido na tradução brasileira "Esmaga, arrasa e cobre" - "De cinzas e de lavas $e$ de pedras" - "De rochas liquefeitas / E de metais e de abrasada areia".

Atualmente, sobre essa superfície, na parte voltada ao mar, cresce vegetação que serve de pasto para as cabras; enquanto que, no outro lado, em direção ao monte, o homem indiferente 
ergue novas cidades, tendo-lhe servido de base as antigas. Todavia, a ameaça permanece ainda, visto que os amplos vértices do monte parecem quase pisar nos muros abatidos das antigas cidades.

Concluindo a estrofe, o poeta demonstra que a natureza não tem maior consideração para com o homem do que com as formigas. Se essas são por sua vez mais atingidas e lesadas do que o homem, isso acontece somente porque ele é menos fértil em suas gerações.

Ben mille ed ottocento

Anni varcàr poi che spariro, oppressi

Dall'ignea forza, i popolati seggi,

240 E il villanello intento

Ai vigneti, che a stento in questi campi

Nutre la morta zolla e incenerita,

Ancor leva lo sguardo

Sospettoso alla vetta

245 Fatal, che nulla mai fatta più mite

Ancor siede tremenda, ancor minaccia

A lui strage ed ai figli ed agli averi

Lor poverelli. E spesso

Il meschino in sul tetto

250 Dell'ostel villereccio, ala vagante

Aura giacendo tutta notte insonne,

E balzando più volte, esplora il corso

Del temuto bollor, che si riversa

Dall'inesausto grembo

255 Sull'arenoso dorso, a cui riluce

Di Capri la marina

E di Napoli il porto e Mergellina.
Mil e oitocentos anos

Passaram-se depois de destruídas

Pela ígnea força as vilas e cidades,

E o camponês, com planos

De bem cuidar das vinhas que nos campos

A morta e incinerada gleba nutre,

Levanta o olhar ainda

Medroso para o cume

Fatal que lá, talvez nunca amansado

E ainda apavorante, é ameaça

De estragos a ele, aos filhos e aos haveres

Dos pobrezinhos. Sempre

O coitado, no teto

Da sua casinhola, às intempéries

Exposto, passa a noite inteira insone

E erguendo-se de um salto observa o curso

Do temido fervor que se derrama

Do ventre inesgotável

Sobre o arenoso dorso, reluzindo

Na marina de Capri,

Em Nápoles, no porto e em Margelina.

Nesta penúltima estrofe do poema, o poeta demarca o tempo. Por volta de mil e oitocentos ${ }^{136}$ anos passaram-se de quando a lava destruiu as cidades de Pompeia, de Herculano e de Estabia. Duramente, crescem, nesses campos ainda encobertos de cinzas, vinhedos que, com tenacidade, vêm cuidados pelo camponês.

\footnotetext{
${ }^{136}$ Conforme afirma o crítico Francesco Biondolillo, a última terrível erupção vulcânica foi em 79 d. C; portanto o período de tempo que separa a época em que Leopardi escreve (1836) dessa última erupção é um pouco inferior aos mil e oitocentos anos conforme indicado no poema. "Piuttosto che essere esatto, [Leopardi] ha voluto destare nel lettore viva impressione circa il molto tempo trascorso e il timore sempre presente di un'altra ruína” - (1952, p. 323 - NT. 237-8).

"Em vez de ser exato, [Leopardi] quis despertar no leitor uma viva impressão referente ao muito tempo transcorrido desde a última erupção e ao temor - sempre presente - de uma próxima ruína." - [Trad. nossa]
} 
Por mais que se tenha passado tanto tempo, o camponês observa com temor o alto do monte fatal, o qual não diminuiu em nada sua vilania, e ainda se apresenta ameaçador para com o camponês, com a sua prole e com seus pobres bens.

É tanto o medo, que o pobre coitado desperta durante a noite, perdendo seu sono, e do alto do teto de seu casebre, exposto às intempéries, põe-se a vigiar, levantando várias vezes para melhor observar o percurso da temida lava. Durante o dia, a lava, como um rio, desce lentamente pelas vertentes do vulcão e ganha um colorido sombrio, sendo que ao anoitecer enrubesce, resplandecendo a marina de Capri, o golfo de Nápoles e o lido de Margelina.

Vários diminutivos foram utilizados nesses versos: "villanello - poverelli e villereccio" traduzidos por “camponês ${ }^{137}$ - pobrezinhos - casinhola”. Ora demonstram o sentimento de piedade do sujeito-lírico em relação aos seres humanos, ora denotam o contraste entre a grandeza do vulcão e a pequeneza do homem.

E se appressar lo vede, o se nel cupo

Del domestico pozzo ode mai l'acqua 260 Fervendo gorgogliar, desta i figliuoli, Desta la moglie in fretta, e via, con quanto Di lor cose rapir posson, fuggendo, Vede lontan l'usato

Suo nido, e il picciol campo

265 Che gli fu dalla fama unico schermo,

Preda al flutto rovente,

Che crepitando giunge, e inesorato

Durabilmente sovra quei si spiega.

Torna al celeste raggio

270 Dopo l'antica obblivion l'estinta

Pompei, come sepolto

Scheletro, cui di terra

Avarizia o pietà rende all'aperto;

E dal deserto foro

275 Diritto infra le file

De' mozzi colonnati il peregrino

Lunge contempla il bipartito giogo

E la creta fumante,
E vendo aproximar-se, ou se no fundo

Da cisterna da casa estiver a água

Gorgolejando, ele desperta os filhos

Às pressas e a mulher e então, com quanto

Pode pegar do que possui, fugindo

Olha de longe o seu

Ninho e o pequeno campo

Que foi da fome a sua só defesa,

Presa do fluxo ardente

Que crepitando vem e inexorável

Para sempre sobre eles se derrama.

Retorna à luz do céu

Depois de longo esquecimento a extinta

Pompéia, um esqueleto

Sepulto que da terra

Avareza ou piedade põe à mostra;

E do deserto fórum

De pé por entre as filas

De colunas quebradas o viandante

Contempla ao longe o bipartido cume

$\mathrm{E}$ a crista fumegante

137 O substantivo camponês não está na forma diminutiva, talvez Affonso Félix de Sousa tenha-o preferido a "campino" - seu sinônimo com aparência diminutiva - já que este último é de baixo uso na língua portuguesa do Brasil. 
Che alla sparsa ruina ancor minaccia. Que a dispersa ruína ainda ameaça.

Caso o camponês aviste o aproximar da lava ou escute o borbulhar da água de seu poço, é sinal de que deve, rapidamente, acordar seus filhos e sua esposa para juntos fugirem. Curiosa é a expressão utilizada no verso 262, “di lor cose rapir posson, fuggendo", pois exprime o desespero dos moradores em salvar o máximo possível de seus pertences. Mesmo sendo os pertences de propriedade da família, o poeta utiliza o verbo "rapir", pois eles de certa forma já estão condenados à destruição; portanto o fato de conseguirem salvá-los é como se estivessem roubando-os da lava. A mesma impressão não se percebe na tradução brasileira, já que o verbo “rapir" foi traduzido por "pegar", não tendo a mesma força arrebatadora dos versos de Leopardi.

No momento da fuga, o pobre camponês volta-se de longe para observar a sua habitual moradia e seu pequeno campo. Esse ambiente, única fonte de sustento seu e de sua família, será tomado pelo fluxo ardente, que sucessivamente o transformará em pedra para sempre.

A velocidade da cena descrita vem reforçada pelo ritmo mais acelerado dos versos, sugerindo o desespero da família. Percebe-se que, do verso 258 ao 269, a pontuação se faz presente para marcar a sucessão dos fatos, assim como a repetição do verbo "destare" nos versos 260 e 261, “desta i figliuoli - desta la moglie” exprimem a rapidez das ações durante a fuga.

A escolha da palavra "crepitando", remete ao som das cintilas vindas do ardor provocado pela lava. Mas a lava não aniquilará tudo velozmente, a presença do advérbio de modo, "durabilmente", desacelera o verso, indicando tanto a lentidão da onda incandescente quanto a firmeza fatal da posse do ambiente pela lava.

Visto que os habitantes dos arredores do Vesúvio vivem em um clima de constante apreensão, o sujeito-lírico projeta tal sentimento na paisagem descrita. Dessa forma, o sentimento de medo e de nulidade do homem vem refletido na cena apresentada, sendo um ambiente noturno.

A cena de destruição de toda uma cidade faz voltar, ao poeta, à lembrança de Pompeia. Essa, após anos de esquecimento, voltou à luz do dia, abandonando sua tumba de pedra. Mas a 
escavação dessas ruínas, para o poeta, só foi feita ou por motivos de avareza da parte do homem, o qual visava obter lucros com as riquezas sepultadas e mais terras; ou por piedade em relação aos infelizes moradores de Pompeia que mereciam honrarias.

Do centro desta antiga cidade, se um estrangeiro visitante ficar de pé e observar entre as filas de colunas despedaçadas verá um cume bipartido: o Vesúvio e o Monte Somma. A crista desse vulcão continua ainda a emanar fumaça, ameaçando as dispersas ruínas.

280 E nell'orror della secreta notte

Per li vacui teatri,

Per li templi deformi e per le rotte

Case, ove i parti il pipistrello asconde,

Come sinistra face

285 Che per voti palagi atra s'aggiri, Corre il baglior della funerea lava, Che di lontan per l'ombre

Rosseggia e i lochi intorno intorno tinge.

Così, dell'uomo ignara e dell'etadi

290 Ch'ei chiama antiche, e del seguir che fanno Dopo gli avi i nepoti,

Sta natura ognor verde, anzi procede

Per sì lungo cammino

Che sembra star. Caggiono i regni intanto,

295 Passan genti e linguaggi: ella nol vede:

E l'uom d'eternità s'arroga il vanto.
E no terrível da profunda noite

Pelos teatros vazios,

Pelos templos sem forma e pelas rotas

Casas, onde o morcego guarda as crias,

Como sinistro facho

Que por ermos palácios, negro gira,

Corre a fulgência da funérea lava

Que de longe entre sombras

De tons vermelhos tinge tudo em torno.

Assim, do homem ignaro e das idades

Que antigas ele chama, e da sequiência

Depois de avós os netos,

E sempre verde a natureza ao ir-se

Por tão longo caminho

Como imóvel. Caem reinos todavia,

Passam povos e línguas: ela ignora,

E o homem de ser eterno se gloria.

Sempre envolto em uma paisagem noturna, o poeta continua a descrever a invasão da lava. Todo o ambiente é sinistro e transmite uma intensa sensação funérea. A noite está tão escura que esconde tudo, e é nesse horror que, lentamente, como uma tocha lúgubre que vaga pelos palácios vazios de pessoas vivas; a lava invade os teatros já vazios, os templos deformes, sem sua beleza original, as casas quebradas que servem hoje como habitat aos morcegos e suas ninhadas, tingindo tudo de vermelho.

No verso 288, percebe-se a repetição do advérbio "intorno", o qual ajuda a demonstrar a intensidade circular do espetáculo descrito. Na tradução brasileira, a repetição não é mantida, porém Affonso Félix de Sousa recriou em todo o verso uma aliteração em /t/, "De tons vermelhos tinge tudo em torno.", dando uma sensação de espaçamento no verso, assim como a repetição nos 
versos de Leopardi. Da mesma forma, a escolha de expressões que remetem à desolação, presentes em todo o período, também contribui para evocar o caráter inexorável da natureza.

Saindo de um plano descritivo - particular, a tomada da cidade pelo fogo fatal, passa-se a um plano genérico - universal, a humanidade sendo ignorada pela natureza. A natureza parece pouco se importar com a história, com o fluir dos séculos, com as gerações dos seres viventes, pois, imutável, permanece sempre verde e vigorosa. Aquilo que pode parecer milênios aos homens, não é mais que um instante para essa força maior; portanto, o homem em sua breve existência não consegue perceber as mutações naturais que ocorrem em um espaço incomensurável em nível cósmico. Somente quando o homem relaciona o seu tempo de vida com a duração de vida da natureza é que se torna possível perceber a ideia do infinito.

Tamanho é o descaso da natureza em relação aos grandes feitos humanos que podem cair reinos, passar grandes personagens e línguas, mas ela nada vê. E com uma pitada de ironia o poeta critica a arrogância do homem em se considerar eterno.

Curiosa é a pausa marcada devido à presença de dois sinais de pontuação localizados em um único verso, 295, "Passam genti e linguaggi: ella nol vede:”, sendo seguido por um enjambement no verso 296, “E l'uom d'eternità s'arroga il vanto”. Tal recurso contribui para alongar o efeito da indiferença da natureza e ao mesmo tempo para mostrar a ostentação presunçosa humana.

\section{Quinta parte: “A giesta" vv. 297 - 317}

E tu, lenta ginestra,

Che di selve odorate

Queste campagne dispogliate adorni, 300 Anche tu presto alla crudel possanza Soccomberai del sotterraneo foco, Che ritornando al loco

Già noto, stenderà l'avaro lembo

Su tue molli foreste. E piegherai 305 Sotto il fascio mortal non renitente Il tuo capo innocente:

Ma non piegato insino allora indarno
E tu, lenta giesta

Que com matos cheirosos

Adornas estes campos despojados, Também tu, prestes, à cruel potência Sucumbirás ao subterrâneo fogo, Que retornando ao sítio De antes, estenderá o avaro manto Sobre teus tenros bosques. Sob o peso Mortal hás de dobrar não renitente A cabeça inocente:

Mas não dobrada até então, embalde 
Codardamente supplicando innanzi

$\mathrm{Al}$ futuro oppressor; ma non eretto

310 Con forsennato orgoglio inver le stelle,

Né sul deserto, dove

E la sede e i natali

Non per voler ma per fortuna avesti;

Ma più saggia, ma tanto

315 Meno inferma dell'uom, quanto le frali

Tue stirpi non credesti

$\mathrm{O}$ dal fato o da te fatte immortali.
Covardemente suplicando em face

Do futuro opressor; e nem erguida

Com doido orgulho ao campo das estrelas;

Nem no deserto, onde

Por berço e tudo mais

Que sem vontade por azar tivestes;

Porém mais sábia e menos

Débil que os homens, frágeis por demais,

Tuas raças não creste,

Pelo fado ou teus feitos, imortais.

Após tanta reflexão, o poeta conclui o poema retornando à imagem contemplativa da "ginestra". Com um vocativo, dirige-se à maleável flor, a qual embeleza os campos desolados, espalhando, com sua touceira, um agradável perfume.

Fazendo um paralelo com a figura do homem, o poeta iguala a sua cruel sina à flor do deserto. Desta forma, ela também sucumbirá à cruel potência do fluido subterrâneo, o qual, retornando em terras já visitadas, estenderá seu ávido manto incandescente sobre sua frágil vegetação inculta.

Todavia, a giesta não irá impor resistência ao peso da vida, inclinando-se a ele. Mesmo sendo inocente, tendo, em sua existência, proporcionado beleza e bem estar a um ambiente inóspito, não será renitente. Nota-se a rima presente nos versos 305 e 306, "renitente innocente", marcando um sentimento de nobreza e piedade.

Após demonstrar a forte consciência dessa heroica flor em relação à lei da existência, uma pausa se faz notar no verso 306, devido à presença do sinal de pontuação “:”, seguido de uma conjunção adversativa, "Ma", no verso 307, que reforça a existência opositora daqueles que se recusam a seguir o exemplo da giesta, tais recursos são mantidos na tradução brasileira.

À diferença desses homens, a giesta não se inclinará inutil e covardemente suplicando ao seu opressor por piedade. Nem mesmo ficará erguida, demonstrando domínio, com um insensato orgulho, em direção às estrelas ou ao deserto, onde, não por vontade própria, mas do destino, nasceu e viveu. 
Pelo contrário, sendo muito mais sábia e muito menos débil do que os homens, ela não acredita que as suas frágeis gerações se tenham tornado imortais devido aos seus feitos ou por vontade do destino. A presença contraditória das expressões "Ma più saggia, ma tanto/Meno inferma dell'uomo" presentes nos versos 314 e 315, traduzidos por "Porém mais sábia e menos / Débil que os homens", colocam em evidência a oposição entre a giesta e o homem.

A covardia do homem consiste na não aceitação de sua predestinada infelicidade, bem como de sua morte, encarada como o fim definitivo, enquanto que o orgulho humano fundamenta-se na crença de sua imortalidade, tanto na terra, como numa outra vida.

Para Giulio Ferroni, "a mistificação das ideologias oitocentistas, do 'século altivo e tolo', opõe-se à 'luz' do pensamento do século precedente, de um Iluminismo visto por Leopardi como capaz de encarar, sem véus, a realidade da condição natural, na absoluta marginalidade do homem e da história da ordem do cosmo.” (2003, p.112) - [Trad. nossa]

Com base nas palavras de Ferroni, fica clara, portanto, a epígrafe escolhida pelo poeta, " $\boldsymbol{E}$

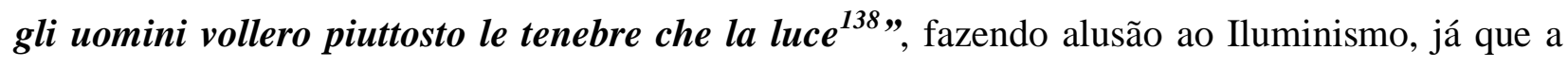
grande maioria dos homens prefere seguir filosofias modernas ilusórias, ficando assim nas trevas ao invés de encarar suas reais condições, desvendadas pelo humanismo e pelo lume da razão. Essa oposição entre treva e luz, que domina todo o poema, torna-se uma inspiração à luta coletiva contra a 'natureza madrasta': 'luta que só uma alma livre dos mitos e das ilusões, desvinculada das ideologias, inclinada contra o 'comum fado' poderia conduzir' (2003, p.112) - [Trad. nossa]

A mensagem presente neste poema é de total conscientização de que o homem deve encarar seu destino, e, como forma de atenuar sua dor, deve construir um mundo mais solidário, com base na compaixão e na fraternidade, conseguindo, assim, combater de forma unida a natureza hostil.

Para tornar a vida mais doce, o poeta, assim como a giesta, exala seu perfume. O primeiro, porém, de forma poética. Portanto, é possível fazer a junção poeta-ginestra e poema-perfume.

\footnotetext{
138“E os homens amaram mais as trevas do que a luz” - [Trad. Affonso Félix de Sousa]
} 
Francesco Biondolillo, crítico italiano, em um comentário sobre o poema em questão afirma:

"La ginestra è, come s'è detto, l'anima, la poesia del Leopardi, medesimo: come essa adorna e sottilmente profuma le squallide campagne intorno, così la poesia di lui, traendo ispirazione dallo squallore della vita spoglia di qualunque illusione, diffonde intorno un soffio di umanità dolce e pensosa". ${ }^{139}$

Interessante é o jogo criado pelo poeta entre a giesta e o homem. A giesta, diante da fúria da natureza, não ergue sua cabeça ao céu para demonstrar altivez, não quer se sobressair diante de outras criaturas, tampouco luta inutilmente contra o seu destino. Pelo contrário, a giesta encara de modo consciente o seu destino, sem, no entanto, perder a sua dignidade. Da mesma forma deveria se comportar o homem, seguindo o nobre e heroico comportamento da flor do deserto, e não se inclinando às utopias filosóficas, as quais iludem a humanidade com falsas promessas.

Ao encarar com dignidade o seu destino, o homem deveria construir um mundo mais solidário, acreditando na compaixão e na fraternidade, de modo a combater, todos juntos, “in una social catena", um inimigo comum: a natureza, única e verdadeira culpada pela infelicidade sentida.

Em suma, é possível notar que, na verdade, a constante negação dos valores da vida presente na temática leopardiana, não faz mais que demonstrar o amor do poeta pela vida, pela poesia e pelo canto, deixando como mensagem final, conforme visto no poema analisado, a solidariedade humana.

\footnotetext{
${ }^{139}$ LEOPARDI, G. "Canti e prose scelte", Introduzione e Commento di Francesco Biondolillo, Firenze: Vallecchi editore, 1952, N. 297-299, p. 326.

"A giesta é, como já se falou, a alma, a poesia do próprio Leopardi: assim como ela enfeita e sutilmente perfuma os esquálidos campos nos arredores, também a poesia de Leopardi, que se inspirando na esqualidez da vida, privada de qualquer ilusão, espalha em volta um sopro de humanidade doce e pensativa." - [Trad. nossa]
} 


\section{Considerações finais}

O presente trabalho buscou analisar a progressão do pensamento de Giacomo Leopardi ao longo de sua produção lírica. Para isso, escolheu-se analisar estilisticamente quatro poemas do autor: Il passero solitario, L'Infinito, Canto notturno di un pastore errante dell'Asia e La ginestra, o il fiore del deserto, os quais acredita-se representarem cada um, uma fase de seu pensamento: "pessimismo individual", "pessimismo histórico", "pessimismo cósmico" e "pessimismo heroico".

Dada a importância do autor escolhido em relação à história da literatura italiana, viu-se relevante introduzir nessa pesquisa elementos de sua biografia de modo a situar o leitor, que por ventura não teve acesso a tais informações, com fatos importantes ocorridos na vida do autor, os quais se acredita terem contribuído com o desenvolvimento de seu pensamento. A difícil relação mantida com seus pais, bem como a sensação de sufocamento que the transmitia o ambiente recanatense são fatos biográficos que se crê terem contribuído muito com o isolamento do poeta, fazendo-o se sentir infeliz.

Ao longo da história literária, os estudiosos direcionaram boa parte da atenção para caracterizar o pessimismo leopardiano, por isso, fez-se nessa análise, um breve estudo da crítica do autor, demonstrando a oscilação dos teóricos a respeito dos possíveis motivos que teriam levado Leopardi a desenvolver sua visão do mundo e colocá-la em seus poemas. Enquanto uns defendiam a opinião de que fora a saúde precária do poeta responsável por fazê-lo ter uma visão pessimista da vida, outros acreditavam ter sido suas experiências vividas, junto aos fatos históricos da época, que transformaram Leopardi em um poeta pessimista; outros ainda avistaram otimismo na mensagem profunda leopardiana escondida atrás de um pessimismo aparente.

Visto que o presente trabalho buscou analisar partes da produção lírica leopardiana, que caracterizasse as fases do pessimismo do autor, em um primeiro momento, viu-se necessário apresentar os conceitos de Leopardi em relação aos gêneros da poesia. Entre os três principais lírico, épico e dramático - considerados pelo poeta, o lírico tornou-se o gênero por excelência, 
por ser, segundo Leopardi, originado do coração e da alma, expressão da natureza que fala dentro do poeta e por isso seria ele, então, o gênero mais apto a receber os profundos e sinceros lamentos do poeta-filósofo da modernidade, o qual está consciente de sua real condição na Terra. A modernidade de Leopardi, entre outros motivos, está presente em sua predileção pelo gênero lírico, e vai contra os padrões da antiguidade, já que os clássicos enalteciam o gênero épico e trágico, e de seus contemporâneos, os quais abandonavam cada vez mais os versos e adotavam a prosa com a narração e o drama.

No segundo momento desse trabalho, fez-se uma explanação do método que se seguiria durante as análises interpretativas dos poemas selecionados. Visto que um dos objetivos do trabalho foi fazer uma análise relacionando o plano da expressão ao do conteúdo, apresentou-se, então, ideias dialogantes com a língua e a literatura, baseadas em diversas teorias, focando a atenção na abordagem estilística, de modo a construir o sentido do texto. Detalhes como seleção verbal, sintaxe, elementos lexicais, recorrência sonora, entre outros elementos têm seu valor expressivo, que também colaboram com a formação de sentido. Um dos papéis da análise estilística é o de interpretar essas escolhas apresentadas nos poemas, centralizando o olhar do estudioso no texto e não mais no seu autor.

Uma vez cientes de que qualquer texto apresenta elementos que estimulam os julgamentos de valor do leitor, e de que um desses pontos pode representar a chave de leitura que levará o leitor ao interior da obra, ou seja, à mensagem do texto, o intuito aqui foi verificar se nas traduções dos textos analisados também foram mantidos os mesmos elementos presentes nos originais.

Conforme visto, críticos como Roman Jakobson defendem a possibilidade de se traduzir a experiência cognitiva, mantendo assim a equivalência entre as mensagens dos textos (original/tradução). No caso de um poema, porém, em que todas as equações verbais tornam-se elementos construtivos do sentido final e transmitem uma significação própria, a traduzibilidade é considerada impossível, solucionada somente com uma transposição criativa, ou seja, transposição intralingual, inter-semiótica ou interlingual do texto, visando sempre à equivalência da mensagem. 
Outros críticos, como Walter Benjamin, defendem a traduzibilidade da forma do texto. Assim, a tradução não deveria procurar assemelhar-se ao sentido do texto original, mas recriar seus detalhes, visto que o sentido do original liga-se precisamente a cada palavra do texto e ao modo como todas as palavras são adotadas.

Diante de ideias antagônicas, importante foi também apresentar a reflexão de Giacomo Leopardi em relação à teoria da tradução, visto que o poeta não se posiciona num polo ou no outro da traduzibilidade de um texto; o que ele propõe é uma síntese entre a tradução "literal" e a "adaptação".

Para Leopardi, um tradutor deve observar minuciosamente um texto, mas sem se esquecer de observar também o estilo do autor. Para isso, o poeta italiano propõe aplicar o método da câmera escura, em que o tradutor projeta o texto original em sua mente, e nesse universo ele "sente" e "aprecia" a língua original, para em seguida reproduzir em sua língua um texto com os artifícios literários e mensagem do texto original.

O poeta ainda defende a tradução como um importante recurso para propagar no tempo e no espaço a obra de um escritor. Tal ideia se comprovou graças não somente aos numerosos estudos dedicados às obras de Leopardi, mas também às muitas traduções, em diversas línguas, de sua obra, que continuam atraindo a atenção de numerosos leitores, que porventura não têm acesso à obra em língua original, desejosos de instaurar um diálogo com o autor por meio da leitura de seus escritos.

A fim de abrir horizontes, no sentido de novas pesquisas e perspectivas da poética leopardiana, fez-se nessa pesquisa um cotejo entre os poemas selecionados e as suas traduções em língua portuguesa do Brasil, paralelamente, de modo que a análise estilística, feita em etapas, contribuísse para mostrar o sentido do texto poético e sua presença (ou não) na versão traduzida.

O primeiro poema analisado foi Il passero solitario, cuja temática supõe-se representar a primeira fase do pessimismo leopardiano: "pessimismo individual". Como introdução à análise 
interpretativa do poema, fez-se um estudo dos motivos que se acredita terem contribuído com a formação do pensamento pessimista individual de Leopardi, tais como: a vivência em um ambiente familiar rígido e privado de afeto; o angustiar-se com o ambiente recanatense; além de o poeta considerar haver uma sorte adversa somente contra ele, o que o leva a viver em um profundo isolamento.

O poema Il passero solitario apresenta uma visão juvenil em que o eu-lírico descreve o seu "desencaixamento" no ambiente nativo, fugindo dos prazeres da juventude, enquanto seus conterrâneos os gozam alegremente. Assim como o eu-lírico, também um pássaro escolhe viver apartado de seus companheiros, fugindo dos prazeres da primavera; aquilo que os diferencia, porém, é o futuro: o pássaro não se arrependerá de seu estilo de vida, visto que ele age naturalmente; enquanto que o eu-lírico perceberá não ter aproveitado a juventude, melhor fase da vida, e por isso lhe restará somente o remorso.

No cotejo feito entre o poema Il passero solitario, traduzido por Ivan Junqueira como $O$ pardal solitário, percebeu-se que o tradutor tentou manter em parte os artifícios literários do poema, substituíndo-os às vezes por compensações; em alguns momentos, porém, o estilo do autor não foi preservado, como por exemplo, o uso do diminutivo-afetivo - efeito tão caro a Leopardi - que na tradução não foi mantido.

A análise interpretativa do poema L'Infinito foi a segunda a ser apresentada nesse trabalho, identificada como representante do "pessimismo histórico" leopardiano. $\mathrm{O}$ ano em que foi composto, 1819, foi considerado crucial para a base da filosofia de Leopardi, pois foi nesse período que o poeta dedicou boa parte de sua reflexão ao contraste existente entre a natureza e a razão, entre os antigos e os modernos; descobrindo a inutilidade das esperanças e a existência da dor inelutável, ou seja, o caminho traçado pela história, culminando na revelação da nulidade das coisas. Tal ponto marca o início do "pessimismo histórico" de Leopardi.

Para explicar a nulidade das coisas, Leopardi elabora a "teoria do prazer", a qual demonstra que o homem está sempre à procura do prazer infinito, mas que infelizmente a satisfação de tal prazer é impossível, visto que o homem vive num mundo limitado. A única 
forma que ele tem para conseguir realizar seus desejos infinitos é utilizando a sua faculdade imagética. E é nela que está a base da mensagem do poema L'Infinito: ao criar imagens vagas, leves e indefinidas e ao naufragar em um mundo fora do tempo e do espaço, o homem se destaca da razão, satisfazendo assim seu desejo de prazer.

Conforme observado na tradução de Ivo Barroso, o poema $O$ Infinito conservou boa parte dos recursos presentes no original, como por exemplo, as aliterações e a presença de adjetivos polissilábicos; e em parte, o recurso de aproximação criado por meio dos pronomes demonstrativos (questo-a) e substituindo-os em outros casos por palavras de campo semântico oposto (mundo real/mundo cósmico) como meio de apresentar a aproximação/distanciamento do eu-lírico em relação ao objeto em questão. Todavia, em relação à mensagem central do poema, percebe-se que o termo-chave "mi fingo", foi substituído por "vou sonhando", lá onde o eu-lírico podia fingir espaços e tempos infinitos, vivenciando-os na imaginação de um modo tão intenso que parece ser quase que real, com o sonhar da tradução, tem-se a impressão de que as sensações são menos intensas, por ser apenas um sonho, perdendo assim a "aparência" do real, e, portanto, não proporcionaria o abandono de si mesmo num mundo criado como meio para encontrar a felicidade e o prazer.

O terceiro poema escolhido como representante da fase do "pessimismo cósmico" leopardiano foi o Canto notturno di un pastore errante dell'Asia. Na terceira fase do pessimismo de Leopardi, a concepção de uma natureza benigna e providencial entra em crise e passa a ser vista como um mecanismo cruel que imbui nos homens um desejo infinito, mas ao mesmo tempo irrealizável no mundo real, condenando não somente os homens, bem como todas as criaturas à perpétua infelicidade. A razão nesse momento passou a não ser mais vista como inimiga dos seres humanos, pois é graças a ela que o homem pôde se conscientizar de sua real situação na Terra, passando a sentir plenamente suas limitações e insignificância diante do universo.

No poema Canto notturno di un pastore errante dell'Asia o eu-lírico indaga-se sobre o sentido da vida humana e cósmica. O canto do pastor e suas inquietantes perguntas à lua parecem surgir em virtude de uma condição que acomete os seres humanos: o tédio. Por mais que os animais não tenham consciência de sua condição de infelicidade na Terra, o eu-lírico conclui que, 
sendo o ser animal ou humano, é sua desventura nascer. É o "pessimismo cósmico" leopardiano presente na mensagem do poema.

José Paulo Paes, em sua tradução do poema Canto noturno de um pastor errante da Ásia, apresenta em alguns momentos construções que levam o leitor a uma interpretação diferente da dos versos do original leopardiano; o tradutor consegue, por outro lado, apresentar soluções bastante criativas em outros pontos. Os recursos sonoros foram bem conservados ao longo da tradução brasileira, como é o caso, por exemplo, das rimas, do ritmo e das expressões ecoantes, apresentando, onde necessário, recursos compensatórios para recriar o mesmo efeito do original; todavia, em partes consideradas importantes para a compreensão da mensagem do poema, o tradutor propõe construções que desviam a atenção do leitor do foco, como é o caso, por exemplo, do paralelismo construído no poema de Leopardi entre a vida da lua e a do pastor, entre o fazer e o caminhar de ambos; tal relação não é mantida na tradução, apresentando a descrição da vida lunar um tanto confusa e não mantendo a analogia com a descrição da vida do pastor.

La ginestra, o il fiore del deserto foi o último poema analisado, escolhido como representante da quarta fase do pessimismo leopardiano: "pessimismo heroico". Uma vez consciente de que a verdadeira culpada pela infelicidade dos seres vivos é a natureza, e de que graças à razão o homem torna-se consciente de seu destino de dor e de infelicidade, Leopardi direciona agora a sua atenção ao modo como o homem deveria se comportar. Em vez de se desgastar em inúteis guerras fratricidas ou se entregar a soluções covardes ou soberbas, o melhor caminho que o homem deveria seguir, de acordo com o poeta, é o da solidariedade.

No poema analisado, tem-se uma recapitulação do pensamento leopardiano a respeito da relação entre a natureza e a sociedade, levando em consideração o presente, o passado e futuro das criaturas. Partindo de uma frágil criatura, a giesta, o eu-lírico aos poucos chama em causa a geografia, a história, as catástrofes, o destino da sociedade e do cosmo, direcionando o olhar do leitor para aquela que seria a única "solução" para a humanidade: o abandono das ilusões, encarando a realidade e sabendo confederar-se contra a natureza inimiga. A mensagem final do poema remete àquela que seria central para o "pessimismo heroico" leopardiano: seguir um 
caminho de valores como a concórdia e a fraternidade, preservando a própria dignidade e aceitando assim heroicamente o destino reservado aos seres vivos.

Ao confrontar o poema de Leopardi e a tradução de Affonso Félix de Sousa, A giesta, ou a flor do deserto, percebeu-se que a o texto traduzido é bastante fiel ao original. Os artifícios poéticos foram mantidos em boa parte do poema, o que sugere o cuidado do tradutor com a forma do texto - elemento fundamental para a criação do sentido que o poeta quis transmitir. Além da reprodução fiel dos jogos sonoros, como as aliterações, assonâncias e rimas, a atenção do tradutor foi dedicada também àqueles detalhes que aparentemente poderiam passar despercebidos, mas que na realidade têm grande importância na composição poética, tais como, a pontuação, a hierarquia das palavras nos versos, a estrutura do período, a rapidez sintática dos versos, a multiplicidade de significados atribuídos às palavras, entre outros. Manteve-se, também, na tradução em questão, boa parte do marcante estilo leopardiano, como a dramaticidade e intensidade dos versos.

Em suma, espera-se que o estudo apresentado nesse trabalho sirva de estímulo aos leitores para prosseguirem com novas pesquisas sobre obras italianas no Brasil, especialmente, estudos de análise poética, teoria dos gêneros e da tradução apresentadas por Giacomo Leopardi. 


\section{Bibliografia}

\section{Do autor}

LEOPARDI, G. Canti. Org. Carlo Calcaterra, Torino: Società Editrice Internazionale, 1947.

. Canti. Org. Emilio Peruzzi. Milano:Biblioteca Universale Rizzoli; 1998.

. Canti. Org. Lucio Felice, Roma: Newton \& Compton editori, 1999.

. Canti. Org. Mario Fubini e Emilio Bigi Torino: Loescher Editore, 1964.

. Canti e prose scelte. Org. Francesco Biondolillo, Firenze: Vallecchi Editore, 1952.

. Discorso di un italiano intorno alla poesia romantica - (1818). Org. Ottavio Besomi; Bellinzona: Edizioni Casagrande, 1988.

. Epistolario di Giacomo Leopardi. Org. Prospero Viani. Napoli: Giuseppe Marghieri, $2^{\mathrm{a}}$ ed., 1860. (Esta obra também está disponível em: http://cronologia.leonardo.it/leopardi/leop001.htm).

. I Canti. Org. Francesco Flora, Milano: Arnoldo Mondadori Scuola, 1957.

. Lettere. Org. Sergio Solmi e R. Solmi. Torino: Einaudi, 1977. 2v.

. Operette Morali. A cura di Marco Antonio Bazzocchi. Milano: Arnoldo Mondadori Scuola, 1995.

. Pensieri. Org. Gigi Cavali, Milano: Bur, $2^{\mathrm{a}}$ ed., 2002.

. Pensieri. Org. Antonio Prete, Milano: Feltrinelli, 1994.

. Poesia e Prosa. Org. Marco Lucchesi, Rio de Janeiro: Nova Aguilar, $1^{\text {a }}$ Edição, 1996.

. Zibaldone di pensieri. Milano: Mondadori, Vols.1-2, 1983 e 2007. 
Sobre o autor e obra ${ }^{140}$

BINNI, W. “La nuova poetica leopardiana”; Firenze: Sansoni, 1947

*___ . "L'ultimo Leopardi", in: SAPEGNO, N. Antologia della storia e della critica letteraria. Firenze: G. Marzocco, 1980, v.3, p. 459-464.

*____ “_A se stesso", in: Tre liriche del Leopardi. Lucca: Luccentia, 1959, p. 31-37.

*BLASUCCI, L. “Sulle primi canzoni”, in: SAPEGNO, N. Antologia della storia e della critica letteraria. Firenze: G. Marzocco, 1980, v. 3, p. 423-440.

$*$ . Linee della "Sera del di di festa" - da Leopardi e i segnali dell'infinito. Bologna: Il Mulino, 1985, p. 153-163.

*BONTEMPELLI, M. Pirandello, Leopardi, D’Annunzio. Milano: Bompiani, 1939, p.4551.

BORSELLINO, N.; MARINARI, A. Leopardi. Introduzione all'opera e antologia della critica. Roma: Bulzoni Editore, 1973.

*BOSCO, U. Titanismo e pietá in Giacomo Leopardi. Firenze: Le Monier, p. 23-53.

*BOSI, A. “A natureza, os antigos: Leopardi tradutor”, In: Mito e poesia em Leopardi. $1^{\circ}$ capítulo de tese de Livre-Docência, apresentada à FFLCH- USP, 1970.

CAMPOS, H. "Leopardi, teórico da vanguarda", in: A arte no horizonte do provável. São Paulo: Perspectiva, 1969, pp. 185-192.

CARDUCCI, G. Degli spiriti e delle forme nella poesia di Giacomo Leopardi. Considerazioni. Bologna: Ditta Nicola Zanichelli; 1898.

CATALDI, P.; MARCHIANI, L.; LUPERINI, R. La scritta e l'interpretazione - Storia e antologia della letteratura italiana nel quadro della civiltà europea. Firenze: Palumbo; Vol. 4; Tomo secondo; 1997.

*CROCE, B. Poesia e non poesia. Note sulla letteratura europea del secolo decimonono. Bari: Gius. Laterza \& Figli, 1923.

DE ROBERTIS, G. "Dalle note dello Zibaldone alla poesia dei Canti". In: LEOPARDI, G. Zibaldone di Pensieri. Milano: Mondadori, Vol. 1, 1983.

* _ _ . "Origini e svolgimento della poesia leopardiana", in: SAPEGNO, N. Antologia della storia e della critica letteraria. V.3. Firenze: G. Marzocco, 1980, p.409-420.

\footnotetext{
${ }^{140}$ Todos os títulos assinalados com * encontram-se em tradução brasileira em: Marco Lucchesi (org.) Poesia $e$ Prosa, Rio de Janeiro: Nova Aguilar, 1ª Edição, 1996.
} 
*DE SANCTIS, F. "Epistolário di Giacomo Leopardi”, in: Saggi critici. V.1. Org. Luigi Russo. Bari: Laterza, 1957, p.1-7.

* . Storia della letteratura italiana. $\left(1^{\circ}\right.$ ed. 1870$)$ - Napoli: Antonio Morano, 1890; pp. 461-465.

. "Schopenhauer e Leopardi", in: www.liberliber.it/bibliotec...penhauer_e_leopardi . "Studio su Giacomo Leopardi”. Napoli: Morano, 1885.

FERRONI, G. et alii. Storia e testi della letteratura italiana: restaurazione e risorgimento (1815-1861). Milano: Mondadori Università, 2003.

*FUBINI, M. "Introduzione alle Operette Morali", in: Introduzione alle Operette Morali, Firenze: Vallecchi, 1933, p.30.

*__ . "Metrica leopardiana", in: Introduzione ai Canti di G. Leopardi, Torino: Utet, 1930, p. XXIX.

GUERINI, A. Gênero e tradução no Zibaldone de Leopardi. São Paulo: EDUSP, 2007.

. PETERLE, P. Entrevista a Antonio Prete: "Il grande classico è una costante presenza..." In: Mosaico Italiano: L'infinito mondo di Leopardi. Rio de Janeiro: Editora Comunità; n. 66, giugno/2009, pp. 39-40).

LEOPARDI. T. "Note biografiche sopra Leopardi e la sua famiglia", in LEOPARDI, T.; PANAJIA, A.; Storia di una 'scomoda' presenza nella famiglia del Poeta, Pisa 2002, pp. 138-139

LUPORINI, C. Leopardi progressivo; In: "Filosofi vecchi e nuovi"; Firenze: Sansoni, 1947 (Hoje em "Leopardi progressivo"; Roma: Editori Riuniti, 1980).

*__ . "Leopardi e la 'delusione storica", in: Filosofi vecchi e nuovi, Firenze: Sansoni, 1947, p. 185-193.

*_. . "Naufragio senza spettatore", in: Le dimentsione dell'infinito. Rivista dell'Istituto Italiano di Cultura di Parigi, Milano: Mondadori, 1989, p.48-51.

MILANO, D. "Leopardi", in: Poesia e prosa, Rio de Janeiro: UERJ / Civilização Brasileira, 1979, p. 317-327.

MULINACI, R. "Oltre la siepe. L'infinito di Leopardi"- in traduzione portoghese. In: Revista de Italianística / DLM / FFLCH / USP, nº XVI, 2008, p. 51.

PAES, J. P. Gaveta de tradutor - versões de poesia. Santa Catarina: Letras Contemporãneas, 1996. 
PASSIGATO, G.; ZOIA, R., "La letteratura italiana per la maturità. '800- '900”, Clio,2a ed., 1993, p.128.

PRETE, A. Il pensiero poetante. Saggio su Leopardi. Milano: Feltrinelli, 1980. (Prima edizione ampliata, in: Universale Economica - Saggi - 2006).

. Finitudine e Infinito: su Leopardi. Milano: Feltrinelli, 1998.

*PUPPO, M. "Poetica di Leopardi", in: Poetica e cultura del romanticismo. Roma: Lanesi, 1962, p. 45-70.

RANIERI, A. Sette anni di sodalizio com Giacomo Leopardi: ristampa dell'unica e rarissima edizione del 1880 con aggiunta di lettere non ancora raccolte del Leopardi e del Ranieri. Napoli: Ricciardi Editore, 1919. (Disponível em: http://www.archive.org/details/setteannidisodal00raniuoft" - acesso em 22/03/10)

RICCI, C.; SALINARI, C. Storia della letteratura italiana. Con antología degli scrittori e dei critici. Roma: Edizione Laterza, V. $3^{\circ}$ - L'Ottocento, 1993

*SAINTE-BEUVE. "Portrait contemporains IV. Paris: Didier, 1855, p.384-389.

*___ . "Poetica di Leopardi", in: Compendio di storia della letteratura italiana, V. 3, Firenze: La Nuova Italia, 1980, p. 245-252.

SAPEGNO, N. "Giacomo Leopardi", in: Storia della letteratura italiana, Milano: Garzanti, 1969

. In: BALBONI, P. CARDONA, M. Storia e testi di letteratura italiana per stranieri. Perugia: Guerra Edizioni, 2ª Edição, 2004, p. 164.

SOLMI, S. "Il pensiero in movimento in Leopardi". In: LEOPARDI, G. Zibaldone di Pensieri. Milano: Mondadori, Vol. 1, 1983.

TIMPANARO, S. Classicismo e illuminismo nell'Ottocento italiano. Pisa: Nistri-Lischi, 1965

UNGARETTI, G. "Imagens de Leopardi e nossas", in: Razões de uma poesia, Trad. De WATAGHIN, L. São Paulo: Edusp, 1994, p.125-134.

*VOSSLER, K. "Le idee del Leopardi sull'arte e sulla lingua", in: Leopardi, Trad. De T. Gnoti, Napoli: Ricciardi, 1925, p.148-171.

ZUMBINI, B. Studi sul Leopardi; Firenze: Le Monnier; 1902. 


\section{Sobre análise-interpretativa}

ARISTÓTELES. Poética. Trad. Eudoro de Sousa. Porto Alegre: Editora Globo,1966.

ARROJO, R. O signo descontruído. Campinas: Pontes, 1992.

. Oficina de tradução: a teoria na prática. São Paulo, Editora Ática, 1986.

. Tradução, desconstrução e psicanálise. Rio de Janeiro: Imago Editora, 1993.

AUBERT, F. H. As (in)fidelidades da tradução: servidões e autonomia do tradutor. Campinas: Editora da Unicamp, 1993.

BAKHTIN, M. Estética da criação verbal. Trad. Maria Ermantina G. G Pereira. São Paulo: Martins Fontes, 1992.

BARTHES, R. Aula, São Paulo: Cultrix, 8ª ed., 1977; pp. 16,18,20,21 e 23

BERTRAND, D. Caminhos da semiótica literária. Trad. Grupo CASA. Bauru: EDUSC, 2003.

BOSI, A. O ser e o tempo da poesia. São Paulo: Companhia das letras, 7ª Edição; 2004.

BRANDÃO, R. "Para que serve a poesia?" In: Língua e Literatura. São Paulo: FFLCH / USP, 1992/1993, n 20, p. 17-25.

CÂMARA JUNIOR, J. M. Contribuição à Estilística Portuguesa. Rio de Janeiro: Edições da Oragnização Simões, $2^{\mathrm{a}}$ edição ampliada. 1956. p. 65

CAMPOS, H. de. "Da tradução como criação e como crítica". In: Metalinguagem e outras metas. São Paulo: Perspectiva, 1992. p. 32-33.

CANDIDO, A. A literatura e a formação do homem. Revista Ciência e Cultura, set. 1972, p. 804.

. O estudo analítico do poema. São Paulo: Associação Editorial Humanitas, FFLCH - USP, 5 Edição, 2006.

COUTINHO, A. Notas de teoria literária. Rio de Janeiro: Civilização Brasileira, $2^{\mathrm{a}}$ ed., 1978. p. $9-10$

EAGLETON, T. Teoria da literatura: uma introdução. Trad. Waltesir Dutra, São Paulo: Martins Fontes, $4^{\mathrm{a}}$ edição.

ECO, U. Lector in fabula: a cooperacao interpretativa nos textos narrativos, São Paulo: Perspectiva, 1986. 
Obra aberta: forma e indeterminação nas poéticas contemporâneas (1962); Trad. Giovanni Cutolo, São Paulo: Perspectiva, 2005 - Debates; 2.

. Sei passeggiate nei boschi narrativi. Milano: Bompiani, 1994. (Trad. Hildegard Feist. Seis passeios pelos bosques da ficção. São Paulo: Companhia das Letras, 1994.)

FABRE, C. "Poesia e Lingüística". In: Grupo francês de Educação Nova. Orientação: COSEM, M. O poder da poesia. Coimbra: Livr. Almedina, 1980.

FONTANILLE, J. Semiotique du discours. 2ed. Limoges: PULIM, 2003.

GUIRAUD, P. A estilística. Trad. Miguel Maillet, São Paulo: Editora mestre Jou, , 1970.

JAKOBSON, R. Lingüística e comunicação. São Paulo: Editora Cultrix, $7^{\text {a }}$ Edição, 1974.

. Fonema e fonologias - Ensaios - (1967). Rio de Janeiro: Livraria Acadêmica, 1972.

JOLIBERT, J. et alii. Formando crianças produtoras de textos. Porto Alegre: Artmed, 1994, v. II, p.194-207.

KAFKA, F. Lettere, a cura di F. Masini, Milano: Mondadori, 1988, p. 27.

LANDEIRA, J. L. M. L. A construção do sentido na poesia de Manoel de Barros: estudo de elementos expressivos fonéticos e morfossintáticos. FFLCH / USP. Dissertação de mestrado, 2000.

LANES, E. V. Laboratório de literatura. São Paulo: Estrutural, 1978

LEVIN, S. Estruturas Lingüísticas em Poesia. Trad. José Paulo Paes. São Paulo: Cultrix/EDUSP, 1975.

MARTINS, N. S. Introdução à estilística: a expressividade na língua portuguesa. São Paulo: T. A. Queiroz, 1989.

MICHELETTI, G. (Coord.) et alii. Estilística: um modo de ler... poesia. São Paulo: Andross Editora, 2a Edição revisada e ampliada, 2006.

- "Repetição e significado poético (O desdobramento como fator constitutivo na poesia de F. Gullar)”. In: Filologia e Lingüística Portuguesa. São Paulo: Humanitas Publicações - FFLCH / USP, No 1, 1997, pp. 151-164.

. A poesia, o mar e a mulher: um só Vinícius. São Paulo: Escuta, 1994. 
MOLITERNO, I. de A. Imagens, reverberações na poesia de Alberto da Cunha Melo: uma leitura estilística”. FFLCH / USP. Tese de doutorado, 2007.

ORLANDI, E. GUIMARÃES, E. Texto. Leitura. Redação. CENP SEESP, 1990.

PASSOS, C. R. P. "De quadrilha em quadrilha: Drummond em Chico B. de Hollanda". In: BOSI, V. et alii. O poema: Leitores e leituras. São Paulo: Ateliê Editorial, 2001, p. $139-152$.

REIS, C. A. A. Dos.Técnicas de análise textual - Introdução à leitura crítica do texto literário. Coimbra: Livraria Almeida, 1976.

RIFFATERRE, M. Estilística estrutural, São Paulo: Cultrix, 1973

RONCONI, F. Forme e testi. Guida all'interpretazione dei generi letterari e all'analisi dei testi. Milano: Arnoldo Mondadori Editore, 1995.

SAMUEL, R. Manual da teoria literária, Petrópolis: Vozes Editora, 9 Ed., 1997.

SAUSSURE, F. De. Curso de lingüística geral. São Paulo: Cultrix, 1969.

SCHILLER, F. Poesia ingênua e sentimental. São Paulo: Iluminuras, 1995.

SPARANO, M. E. O som e a expressividade em Iracema: lenda do Ceará. FFLCH / USP. Dissertação de mestrado, 2001.

. Balada, canção e outros sons: um estudo fonoestilístico em Língua Portuguesa. FFLCH / USP. Tese de doutorado, 2006.

SPITZER, L. Lingüística e história literária. Madrid: Editorial Gredos, 1955.

- Critica stilistica e storia Del linguaggio - saggi raccolti a cura e com presentazione di Alfredo Schiaffini. Bari: Guis. Laterza \& Filhi, 1954.

ULLMANN, S. "Semântica: uma introdução à ciência da significação." 2ed. Trad. J.a Osório Mateus, Lisboa: Fundação Calouste Gubenkian, 1970, p. 23. In: MOLITERNO, I. de A. Imagens, reverberações na poesia de Alberto da Cunha Melo: uma leitura estilística". FFLCH / USP. Tese de doutorado, 2007.

ZILBERBERG, C. Raison et poétique du sens. Paris: PUF, 1988. 


\section{Sobre tradução e teoria da tradução}

ARROJO, R. Oficina de tradução. A teoria na prática. São Paulo, Ática, 1992 , Tradução, desconstrução e psicanálise. Rio de Janeiro, Imago, 1993

(org.), O signo desconstruído. Implicações para a tradução, a leitura e o ensino. Campinas, Pontes, 1992

AUBERT, F. As (in)fidelidades da tradução: servidões e autonomia do tradutor. Campinas, Ed. da Unicamp, 1993

BALANCIN, D. de S. As traduções de I Fioretti di San Francesco: a leitura da obra no Brasil. FFLCH / USP. Dissertação de mestrado, 2008.

BARTHES, R. "From work to tex". In: HARARI, J. V. ed. Textual strategies; perspectives in post-structuralist criticism. New York, Cornell University Press, 1979. p. 73-91.

BENJAMIN, W. “A tarefa - Renúncia do tradutor”. Trad. Susana Kampff Lages. In: Antologia Bilíngüe - Clássicos da Teoria da Tradução - V.1. (Org.) Werner Heidermann. UFSC - CCE/DLLE. Núcleoo de Tradução, Florianópolis, 2001, pg. $189-215$.

BORGES, J. L. "Pierre Menard, autor do Quixote". Ficções. São Paulo, Abril Cultural, 1972

BUFFONI, F. (org.) Ritmologia. Atti del convegno 'Il ritmo del linguaggio. Poesia e traduzione. Università degli Studi di Cassino. Dipartimento di linguistica e letterature comparate. 22-24marzo 2001. Milão, Marcos y Marcos, 2002.

CAMPOS, H., "Da tradução como criação e como crítica". Metalinguagem. São Paulo, Cultrix, 1976.

CATALANO/SCOTTO (org.), La nascita del concetto moderno di traduzione Le nazioni europee fra enciclopedismo e epoca romantica. Roma, Armando Editore, 2001.

CATFORD, J. C. Uma teoria lingüística da tradução. São Paulo, Cultrix, 1980. (Tradução brasileira de A linguistic Theory of translation; na essay in applied linguistics. Oxford, Oxford University Press, 1965.)

DERRIDA, J. "Freud e a cena da escritura". A escritura e a diferença. São Paulo, Perspectiva, 1971 
ECO, U. Dire quasi la stessa cosa. Esperienza di traduzione. Milano: Bompiani, 2003

FISH, S. Is there a text in this class?; the authority of interpretive communities. Cambridge, Harvard University Press, 1980.

FOLENA, G. Volgarizzare e tradurre. Turim, Einaudi, 1991

FROTA, M. P. A singularidade na escrita tradutória, Campinas, Fontes/Fapesp, 2000.

JAKOBSON, R. Lingüística e comunicação. São Paulo, Cultrix, 1975

KIRSCH, G. "Poética da tradução e recepção estética: Nove, novena na França e na Alemanha". Tese de doutorado, São Paulo FFLCH/USP, 1998.

LADMIRAL, J.-R. et alii, A tradução e os seus problemas. Lisboa, Edições 70, 1980

LAGES, S. K., Walter Benjamin. Tradução e melancolia. São Paulo, Edusp, 2002

LARANJEIRA, M. Poética da tradução. São Paulo, Edusp/Fapesp, 1993

MARTINS, M. A. P. Tradução e multidisciplinariedade. Rio de Janeiro, Ed. Lucerna, 1999

MILTON, J. Tradução. Teoria e prática. São Paulo, Martins Fontes, 1998

NERGAARD, S. (org.), La teoria della traduzione nella storia. Milão, Bompiani, 1993 (org.), Teorie contemporanee della traduzione. Milão, Bompiani, 1995

NIDA, E. Language structure and translation. Califórnia, Standford University Press, 1975.

OLMI, A. Metodologia crítica da tradução literária. Duas versões italianas de Dom Casmurro, Santa Cruz do Sul, Edunisc, 2001

OTTONI, P. (org.), Tradução. A prática da diferença. Campinas, Ed. da Unicamp, 1998

PAES, J. P. Tradução, a ponte necessária. Aspectos e problemas da arte de traduzir. São Paulo, Ática, 1990.

PAZ, O. "Traducción: literatura y literalidad" in: Tradução literatura e literalidade Revista Viva Voz - Trad. Doralice Alves de Queiroz. Belo Horizonte: FALE/UFMG, 2006, p. 12

REGA, L. La traduzione letteraria. Aspetti e problemi. Turim, UTET, 2001

RÓNAI, P. Escola de tradutores, Rio de Janeiro, Nova Fronteira, 1987, 6. ed. 
VENUTI, L. (org.) Rethinking translation. Discourse, Subjectivity and Ideoogy. Londres/ Nova York, Routledge, 1992 , The scandals of translation. Londres/Nova York , Routledge, 1999.

SIGNORINI, I. (org.) Lingua(gem) e identidade, Campinas, Mercado de Letras/FAEP/FAPESP, 1998

WYLER, L. Línguas, poetas e bacharéis. Uma crônica da tradução no Brasil. Rio de Janeiro, Rocco, 2003

\section{Dicionários e Gramáticas}

CEGAllA, D. P. Novísima gramática da língua portuguesa. São Paulo: Editora nacional, 36 ${ }^{\mathrm{a}}$ edição, 1993.

CUNHA, A. G. Da. Dicionário etimológico nova fronteira da língua portuguesa. Rio de Janeiro: Nova Fronteira, 2a Edição, 1986.

DUBOIS, et alii. Dicionário de Língüística. (Dictionnaire de Linguistique - $1^{\mathrm{a}}$ ed. 1973) Direção e coord. da trad.: Prof. Dr. Izidoro Blikstein. São Paulo: Cultrix; 2001

FARACO, C. E.; MOURA, F. M. De. Gramática - fonética e fonologia, morfologia, sintaxe e estilística. São Paulo: Editora Ática, 9a edição, 1996.

FARIA, E. Dicionário Escolar Latino-Português. Rio de Janeiro: Campanha nacional de material de ensino - Departamento nacional de educação - Ministério da Educação

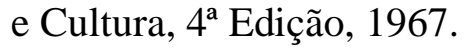

FERREIRA, A. B. De H. Pequeno dicionário brasileiro da língua portuguesa. Rio de Janeiro: Editora Nacional, $11^{\text {a }}$ edição, 1983.

MICHAELIS. Moderno Dicionário de Língua Portuguesa. São Paulo: Melhoramentos, 1998.

MOISES, M. Pequeno dicionário de literatura brasileira. Org. José Paulo Paes, São Paulo, Cultrix Editora, 3ª Edição, 1987.

PARODI, A. M. et alii. Lingua d'oggi-Grammatica italiana con schede operative. Milano: Istituto Geografico De Agostini, 10ª Edizione, 1994.

SANDRON. L'italiano per tutti - Dizionario linguistico grammaticale e dei sinonimi e contrari. Novara: Istituto Geográfico De Agostini, 1987.

ZINGARELLI, N. Il nuovo Zingarelli - Vocabolario della lingua italiana. Bologna: Zanichelli, $11^{a}$ edizione, 1989. 


\section{Sitografia}

http://www.antonioberte.it/Leopardi1.html (site quadros de Antonio Bertè -inspirados nos poemas de Giacomo Leopardi)

http://www.archive.org (site de acesso a livros digitalizados)

http://www.auletedigital.com.br (site dicionário - Aulete - Língua portuguesa)

http://www.bibliotecaitaliana.it (site de acesso a livros digitalizados da Universidade "La sapienza" de Roma)

http://www.books.google.com.br/books (site de busca - livros digitalizados)

http://www.cronologia.leonardo.it/leopardi/leop001.htm (Epistolário on-line de Leopardi)

http://www.demauroparavia.it (site dicionário De Mauro Paravia - Língua italiana)

http://www.dizionari.corriere.it/dizionario_italiano (site dicionário Sabatini Coletti - Língua Italiana)

http://www.infopedia.pt (site dicionário Porto - Língua portuguesa)

http://www.liberliber.it/ (site download livros) 
ANEXOS 
ANEXO A - Claustro da Igreja de Santo Agostino - Recanati

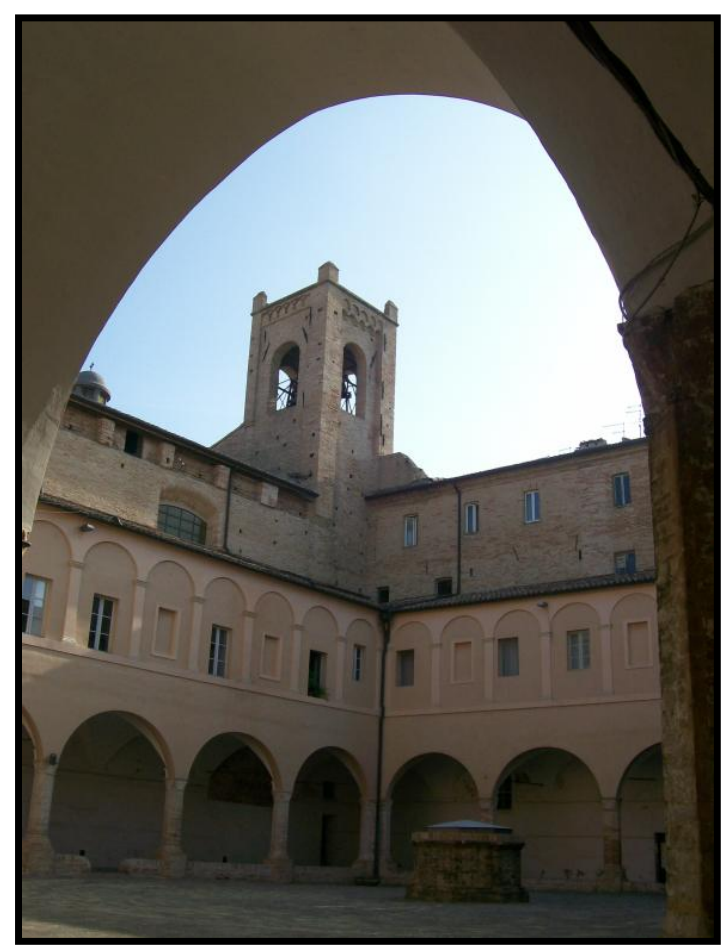

141

Suposta torre de onde voou o pássaro solitário em direção à campina - conforme poema Il passero solitario.

ANEXO B - Rua Tabor

A caminho do Monte Tabor, também conhecido popularmente como Colle dell'Infinito.

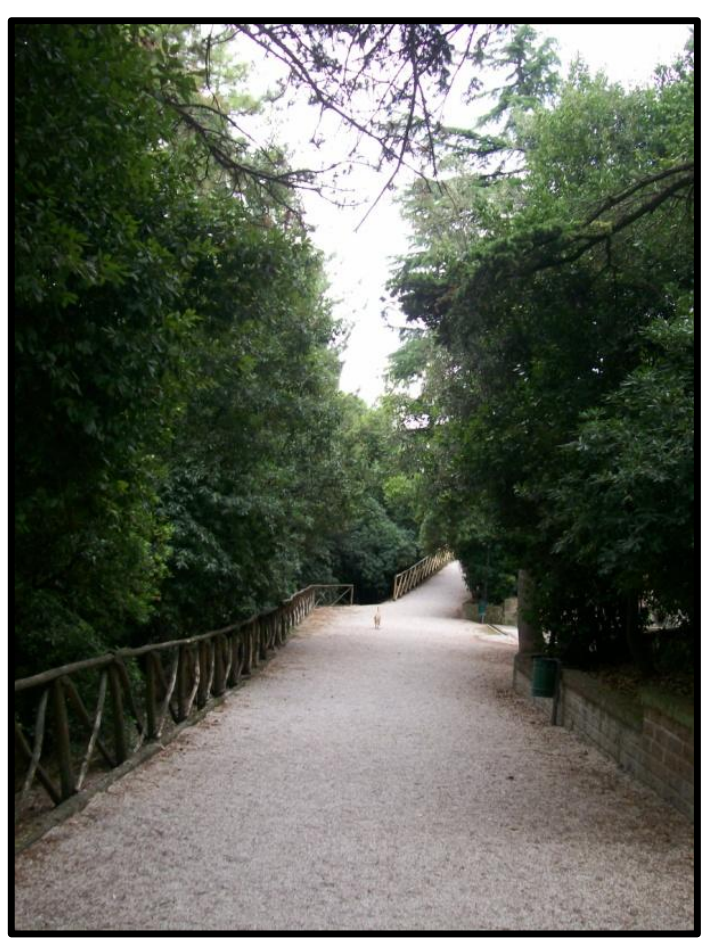

${ }^{141}$ Fotos de arquivo pessoal (anexo A - B - D) - Recanati, 21/09/2009 
ANEXO C - O Colle dell'Infinito

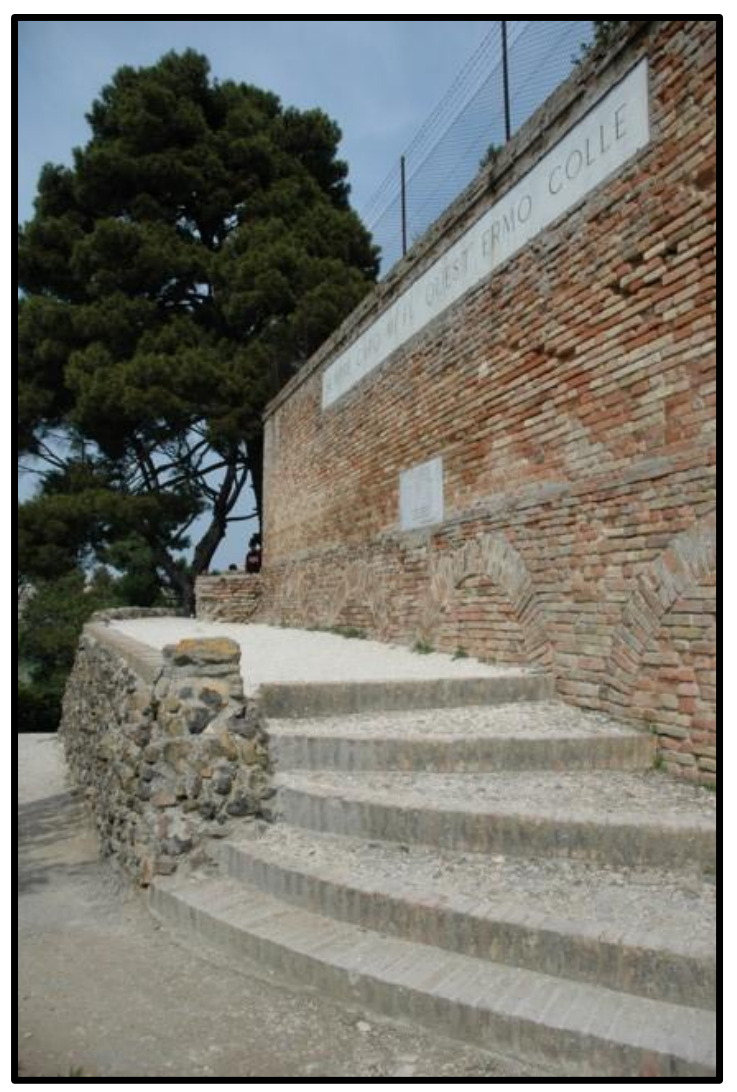

142

Sumidade do Monte Tabor de onde é possível avistar um vasto panorama sob os versos de Leopardi: "Sempre caro mi fu quest'ermo colle"

ANEXO D - Panorama Monte Tabor

Paisagem vista do alto do Colle dell'INFINITO, inspiradora do homônimo poema.

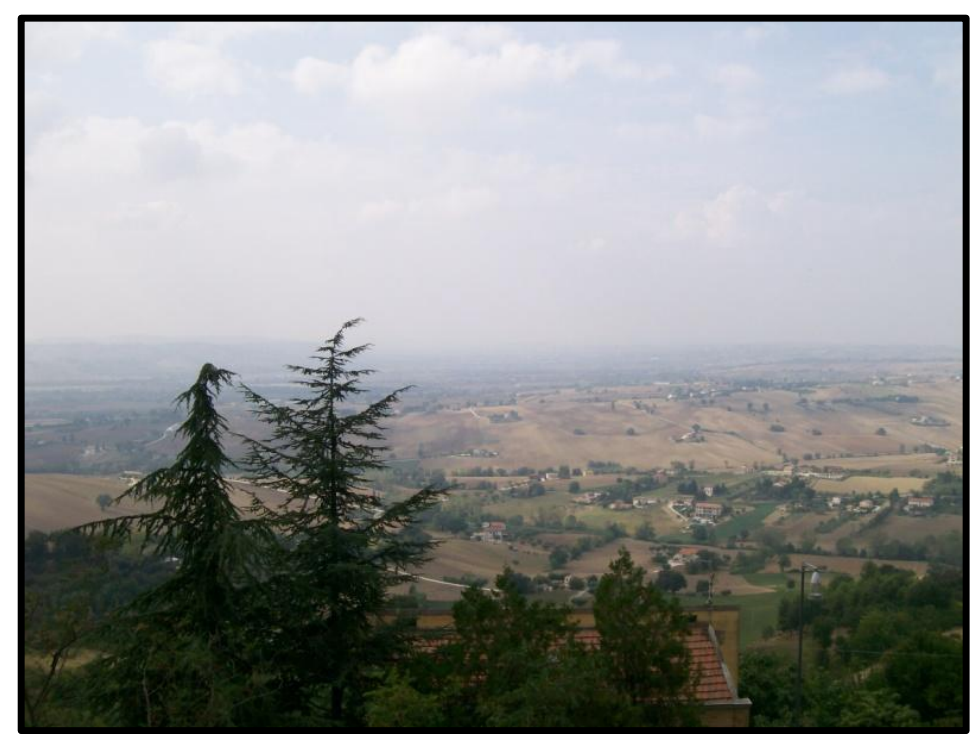

\footnotetext{
142 http://www.funconero.it/itinerari/recanati (acesso em 22/04/10)
} 
ANEXO E - A giesta

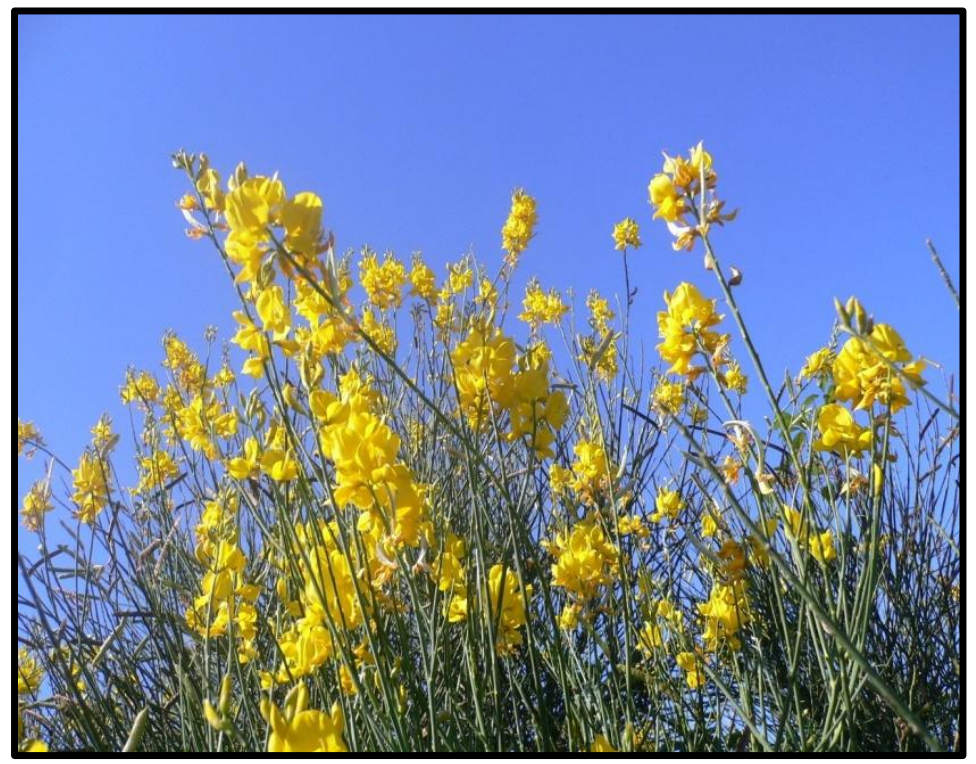

143

\section{Spartium junceum, \\ também conhecida \\ como ginestra odorosa}

ANEXO F - A giesta sobre rocha lávica

Assim como descrito no poema $L a$ ginestra, o il fiore del deserto, vê-se nessa foto um arbusto da flor que espalha sua beleza e perfume na árida paisagem vulcânica.

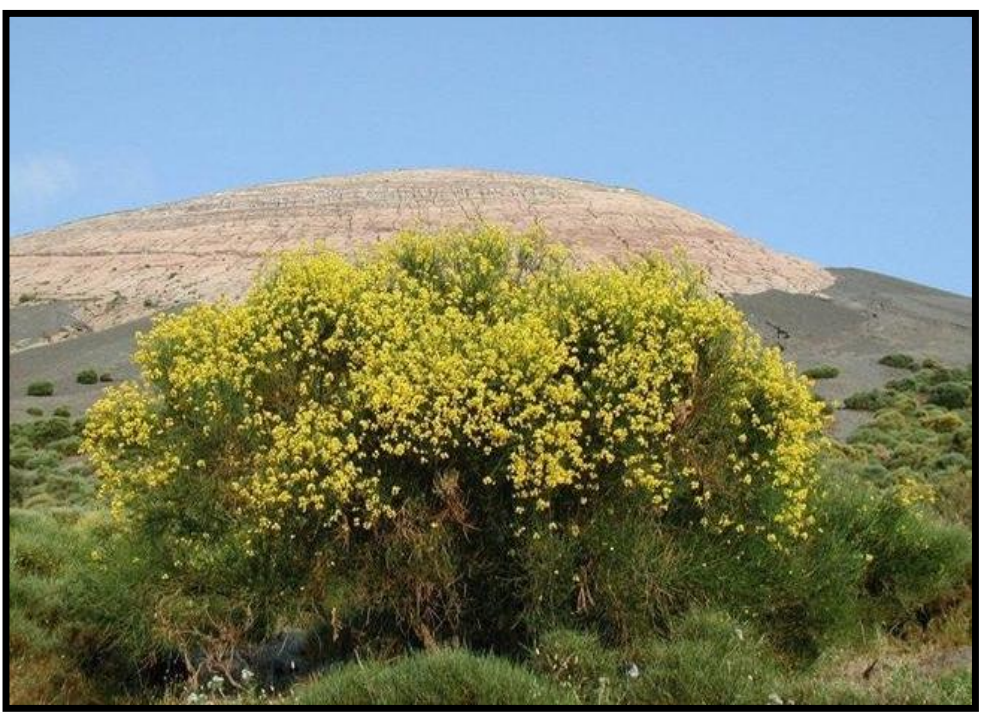

\footnotetext{
${ }^{143} \mathrm{http} / / /$ flickr.com/photos/luigistrano/3766277170/ (acesso em 27/04/10)

$144 \mathrm{http}: / / \mathrm{www}$. fotovallescrivia.it/vscrivia/fotografie-Altro/Fiori-Fauna-Isola-di-Vulcano-Ginestra-746.aspx (acesso em $27 / 04 / 10)$
} 
ANEXO G - Troca de e-mails com MARCO LUCCHESI e IVAN JUNQUEIRA

Roberta Belletti <robertabelletti@ig.com.br>

\section{Re: Omissão de verso no poema traduzido - II passero solitario.}

2 mensagens

marcolucchesi@terra.com.br <marcolucchesi@terra.com.br>

Responder a: marcolucchesi@terra.com.br

Para: Roberta Belletti <robertabelletti@ig.com.br>

prezada amiga

sao pequenos erros q passaram

que esperam pela $2 \mathrm{a}$ revisao abs

marco

On Ter 26/01/10 18:08, Roberta Belletti robertabelletti@ig.com.br sent:

Roberta Belletti <robertabelletti@ig.com.br>

26 de janeiro de 2010 17:08

Para: marcolucchesi@terra.com.br

Bom dia Prof. Lucchesi,

me chamo Roberta Belletti e sou mestranda pela Universidade de São Paulo na área de Língua e Literatura Italiana. Minha dissertação tem como objetivo analisar estilisticamente alguns poemas selecionados de Giacomo Leopardi, comparando-os às traduções publicadas na versão em português no livro: Giacomo Leopardi - Poesia e Prosa, organizado pelo senhor e publicado pela Nova Aguilar em 1996.

Pude observar que nessa edição alguns poemas traduzidos não estão completos, como por exemplo, "Il passero solitario", traduzido por Ivan Junqueira (O pardal solitário). Nessa versão, o verso 13 Non compagni, non voli, - está omitido. Bem como no verso 22 consta a tradução da expressão "da loro" (referindo-se a três complementos verbais) por "dele" (um só complemento) o que modifica a interpretação.

O senhor, gentilmente, poderia me dizer se essas constatações estão na tradução original de Ivan Junqueira (eu fiz uma pesquisa, mas não consegui encontrar em qual obra de Ivan Junqueira consta o poema "O pardal solitário") ou tratam-se de pequenos enganos involuntários na impressão da obra Poesia e Prosa?

Desde já agradeço muito pela gentil ajuda que o senhor me proporcionará.

Atenciosamente

Roberta Belletti 
Roberta Belletti <robertabelletti@ig.com.br>

\section{Re: Tradução de poema}

2 mensagens

Maria Cecilia Barata Costa <ceciliajunqueira@globo.com>

24 de março de 2010 18:17

Para: Roberta Belletti <robertabelletti@ig.com.br>

Roberta,

Ivan já tinha perdido o original deste poema. A principio, voltando ao poema, ele diz que você poderia traduzir este verso da seguinte forma: Sem parceiros, sem voos. Ele prefere parceiros a companheiros ou camaradas...Beijinho, Cecilia.

Em 24 de março de 2010 15:36, Roberta Belletti <robertabelletti@ig.com.br> escreveu:

Bom dia Sr. Junqueira, sou uma pesquisadora e estou preste a concluir o meu mestrado em Língua e Literatura Italiana na USP. Estou estudando a poética de Giacomo Leopardi e suas traduções brasileiras. Consta no livro org. por Marco Lucchesi (Poesia e Prosa) a tradução do poema "Il passero solitario" feita pelo senhor, mas infelizmente o poema não está completo nesta edição, está faltando a tradução do verso 13 (Non compagni, non voli). O senhor poderia, por favor, me dizer para que eu possa completar minha dissertação, qual é a tradução feita pelo senhor desse verso? Agradeço imensamente pela atenção Roberta Belletti

24/3/2010 à(s) $15 \mathrm{~h} 34$

189.78.57.51

[E-mail a partir de "A poesia é traduzível?", no Digestivo Cultural] 


\section{RESUMO}

A presente pesquisa tem como finalidade apresentar uma leitura da obra poética de Giacomo Leopardi, com um olhar atinente à estilística. A fim de abrir horizontes, no sentido de novas pesquisas e perspectivas da poética leopardiana, escolheu-se fazer um cotejo entre poemas selecionados e as suas traduções em língua portuguesa do Brasil, paralelamente, de modo que a análise estilística, feita em etapas, contribua para mostrar o sentido presente no texto poético, sentido esse que pode estar alterado na versão traduzida. Quatro foram os poemas escolhidos: $I l$ passero solitario, L'infinito, Canto notturno di un pastore errante dell'Asia e La ginestra, o il fiore del deserto, representando um conceito que circula há tempo, mas que se acredita manter a sua importância, referente às fases do pessimismo leopardiano: individual, histórico, cósmico e heroico.

Palavras-chave: Giacomo Leopardi; estilística; tradução; literatura italiana; pessimismo leopardiano 


\begin{abstract}
The present study is to present a reading of the poetry of Giacomo Leopardi, with a look regards on the stylistic. In order to open horizons to new research and perspectives of Leopardi's poetry we chose to make a comparison between the selected poems and their translations into Portuguese of Brazil, in parallel, so that the stylistic analysis, done in stages contributes to show the sense in this poetic text, meaning that it can be altered in the translation. Four poems were chosen: Il passero solitario, L'infinito, Canto notturno di un pastore errante dell'Asia e La ginestra, o il fiore del deserto, representing a concept that circulate for some time, but believed to remain important, on stages of Leopardi's pessimism: individual, historical, cosmic and heroic.
\end{abstract}

Keywords: Giacomo Leopardi, stylistics, translation, Italian literature; Leopardi’s pessimism 